ص ص[97-65]

$$
\begin{aligned}
& \text { استخدام سلسلة القيمة كأحد الاستر اتيجيات الحديثة }
\end{aligned}
$$

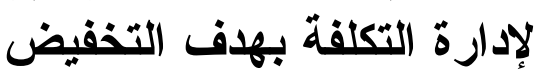

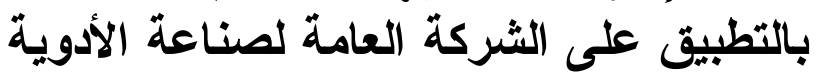

$$
\begin{aligned}
& \text { والمستلزمات الطبية في نينوى العامية ليناعة الأن }
\end{aligned}
$$

$$
\text { هدام عمر حمودي عبد المديدي }
$$

\author{
الدكتور صالح إيراهيم يونس الشعباني

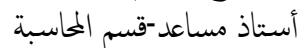 \\ كلية الإدارة والاقتصاد-جامعة الموصل \\ dralshabaney@yahoo.com
}

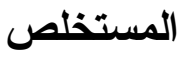

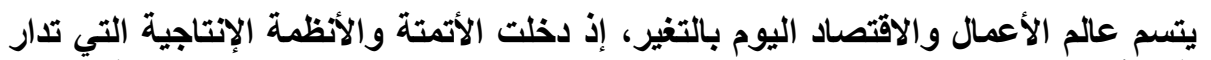

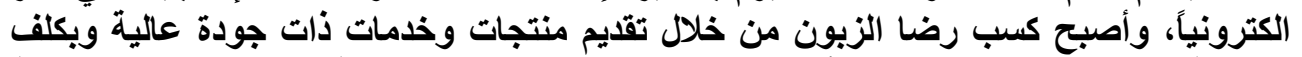

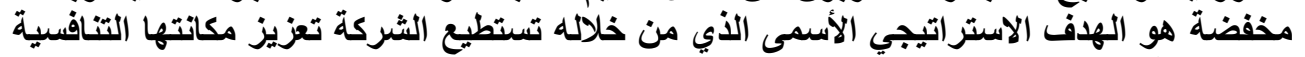

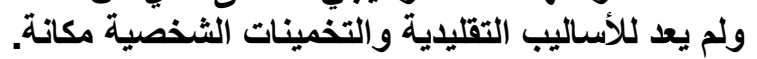

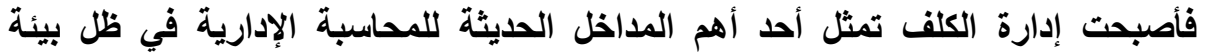

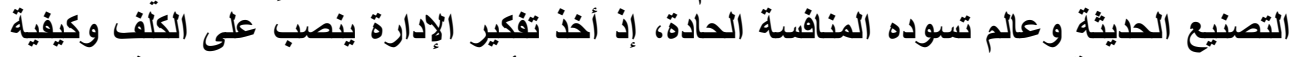

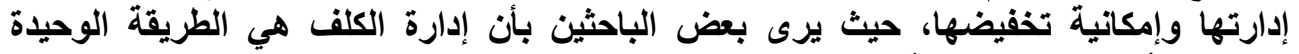
لتحسين الأداء المالي للشركة.

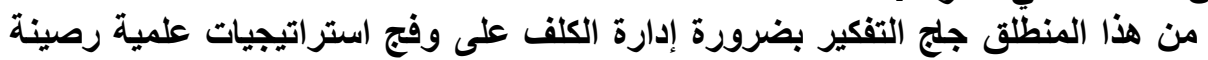

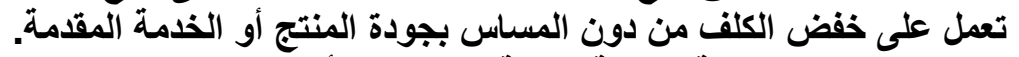

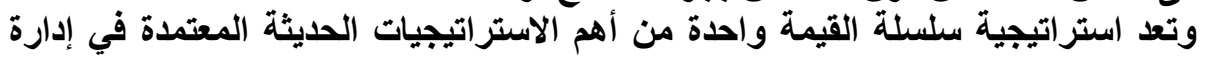

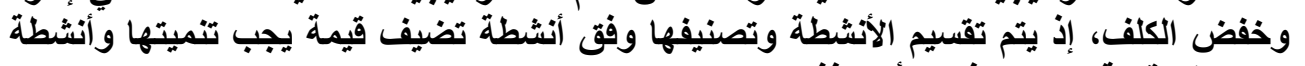

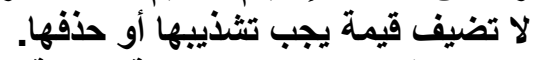

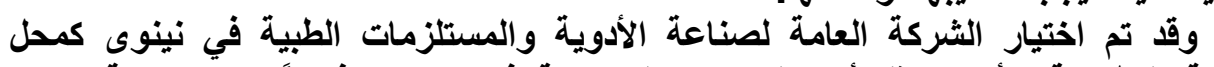

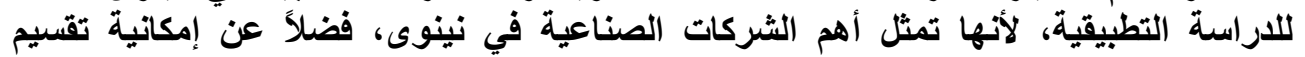
عملياتها الإنتاجية إلى عدة أنشطة رئيسة ألى وفرعية. 


\title{
The Use of Rate Series as one of the Modern Strategies to Cost Management Aiming to the Decrease, with the Application of Sate Company of Drugs Industry and Medical Appliances - Nineveh
}

\author{
Salih I. Younis (PhD) \\ Assistant Professor \\ Department of Accountancy \\ University of Mosul
}

\author{
Hisham O. H. Al-Hadeedy \\ Assistant lecturer \\ Department of Accountancy \\ University of Mosul
}

\begin{abstract}
The world of business and economy nowadays is characterized by change since the productive systems have been electronically administered. The basic goal is how to get the clients by the means of the presentation of high and good quality of both products and services with a lower cost through which the company is able to reinforce its competitive position and the traditional procedures are no longer to be there. The cost management represents one of the most important modern entrances in the computer administration under the shadow of the modern industrialization in a world of sharp competition which made the management thinking base on the costs and how to manage them and how to reduce them for the purpose of improving the financial performance of the company. Depending on what have been mentioned earlier the administration of costs is according to strong and scientific strategies which work for the purpose of the cost reduction without affecting the product quality and the presentation of service. The strategic value series is regarded one of the most important and modern strategies depended upon in the field of administration and cost reduction. The activities have been divided and classified into other activities which added value, possibly developed and doing other activities without any kind of value or importance should be ignored and neglected. The choice has fallen upon the State Company for Drug Industries and Medical Appliances at Nineveh as the place in which the study is going to be held to which represented one of the most important industrial companies at Nineveh and the capacity of the division of its producing operations into different activities.

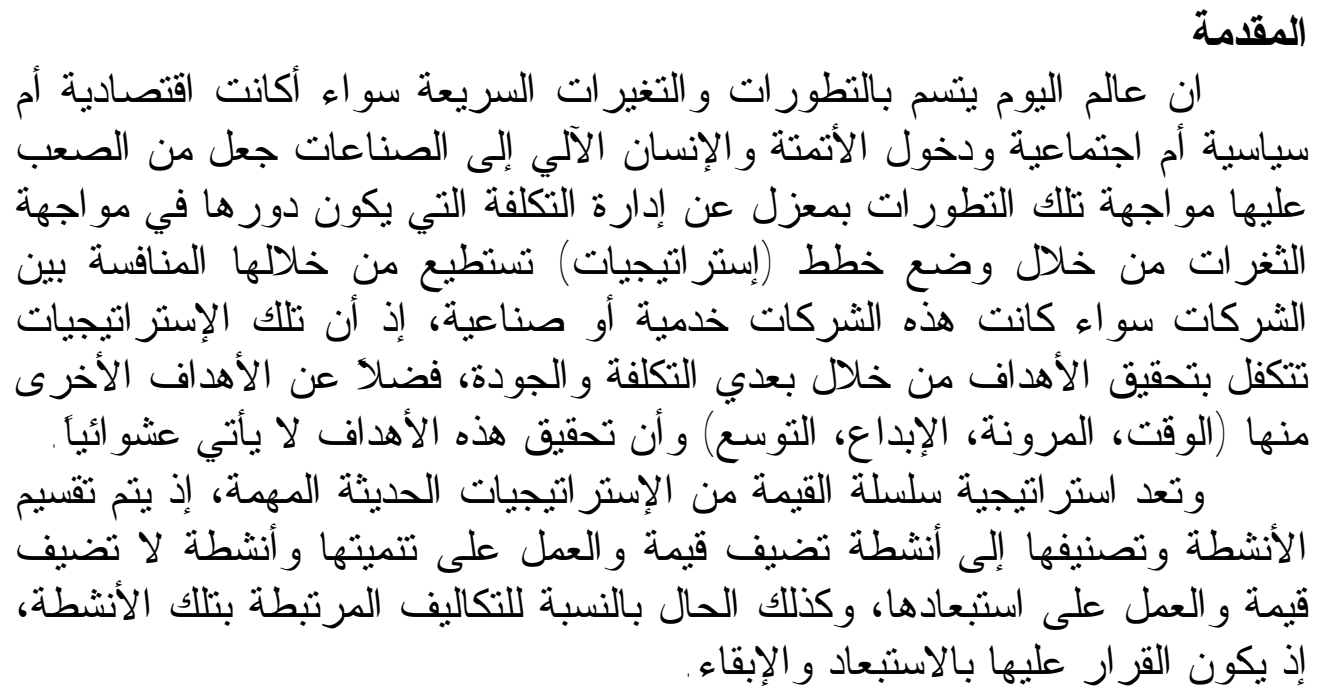


وقد تم اختيار الثركة العامة لصناعة الأدوية و المستلزمات الطبية في نينوى،

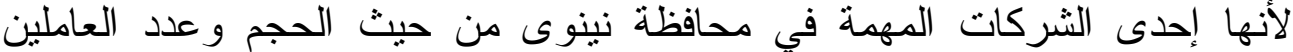

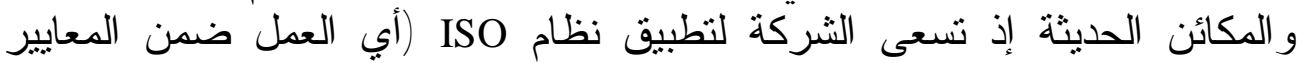

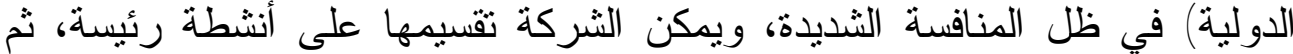
تقسيم تلاك الأنشطة على أنشطة فر عية، ومن ثم يمكن تحديد كلف تلأك الأنشطة.

تكمن أهمية البحث من خلال عرض الدور الذي تؤديه إدارة التكلفة في أهمية البحث أهن

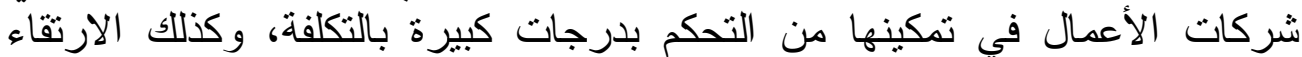

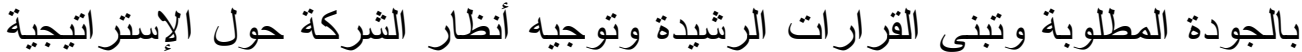
الملائمة التي تحقق هذه الأهداف وبأقل الكلف المدكنة.

مشكلة البحث

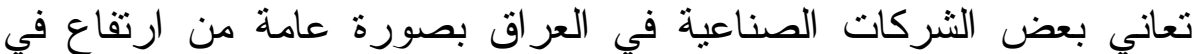

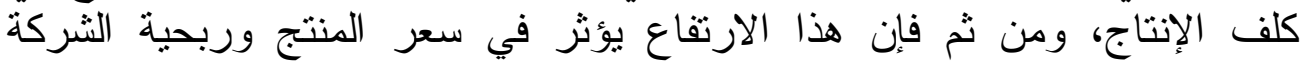

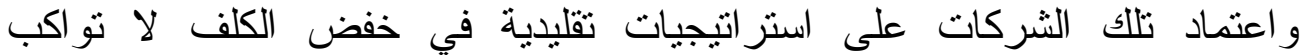

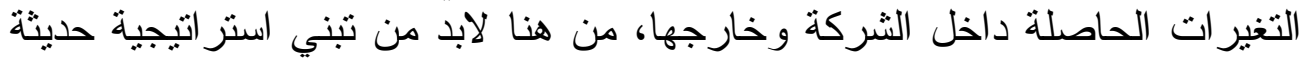

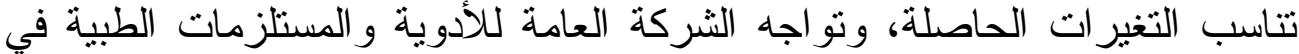

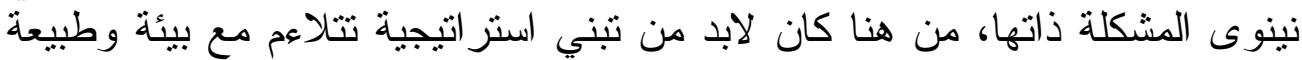
عمل الثركة بحيث تهدف تللك الإستر اتيجية إلى خفض تلفي كلف الإنتاج و المحافظة على لئل

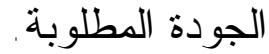

يهدف البحث إلى عرض كيفية استخدام سلسلة القيمة بوصفها إستر اتيجية

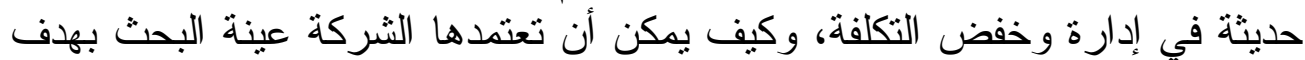
خفض الكلف و الارتقاء أو المحافظة على مستوى الجودة المطلوبة وتعزيز مكانية الكانتها

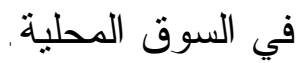
فرضية البحث

إن اعتماد استراتيجية تحليلات هندسة القيمة بصورة خاصة بعمل على القيل تخفيض كلف الإنتاج ويقلل من الجهر مع المحافظة على الجودة ومن ثمة تحنة تحسين على

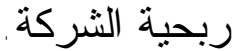

ميدان البحث

تم اختبار الثركة العامة للأدوية والمستلزمات الطبية في نينوى ميدانأ للتطبيق العملي وذلك للأسباب الآتية: 
1. تعد الثركة أرضية ملائمة من حيث تعدد النشاطات ووجود المسارات التكنولوجية التي تخدم تطبيق إستر اتيجية تحليلات هندات هندسة القيمة.

2. وجود وحدة خاصة بحسابات التكلفة تساعد على استخر اج البيانات من سجلات وتقارير الثركة.

3. تعاني الثركة من ارتفاع كلف الإنتاج، مما يؤثر عليها تتافسياً في ظل اقتصاد مفتوح و عليه تسعى محاولة خفض الثف نلانك الكلف.

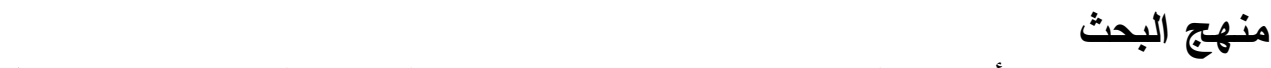

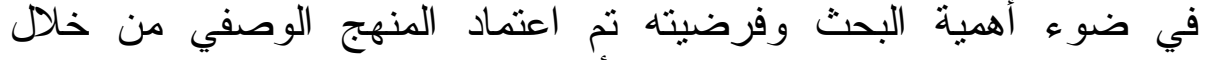

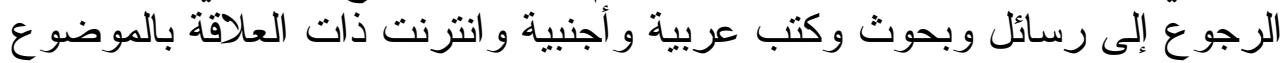

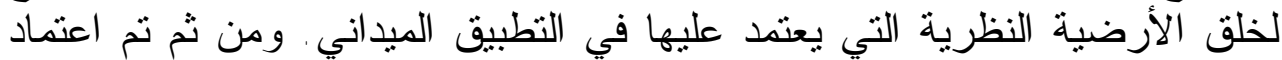
المنهج التحليلي من خلال التطبيق في الثركة.

خطة البحث

تم تقسيم البحث على عدة محاور تتاول الأول مفهوم الاستر اتيجية و أهيتها،

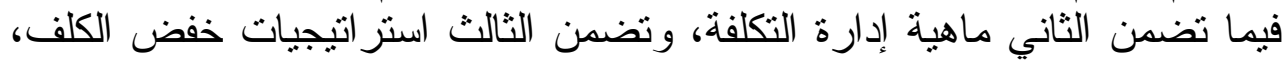
في حين خصص الر ابع للجانب النطبيقي.

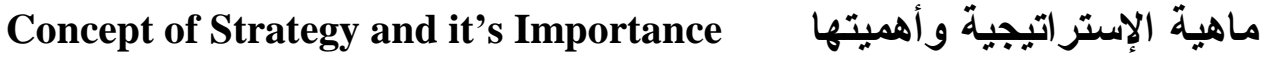

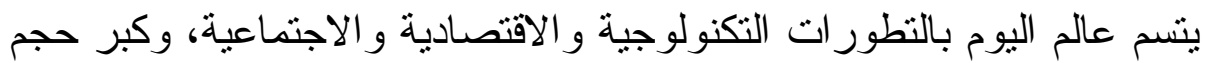

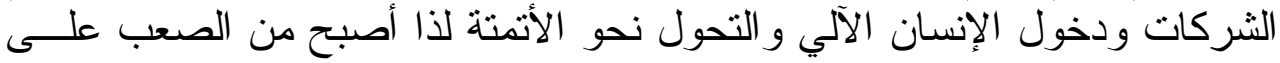

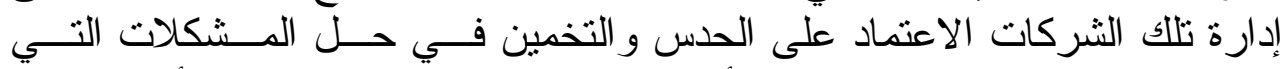

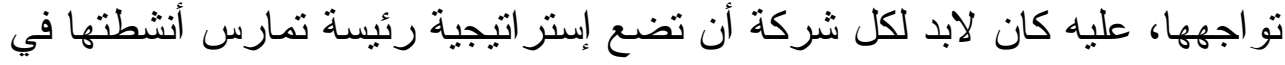

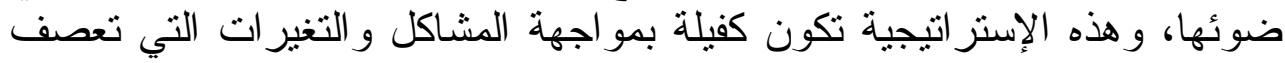

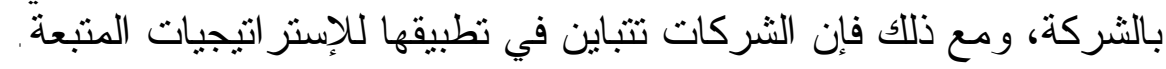

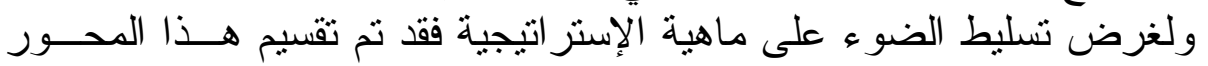

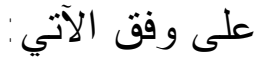

The Beginning of Strategies

أولاً - نثشأة الإستر اتيجية

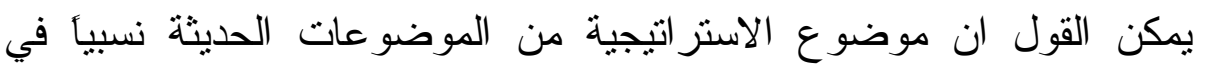

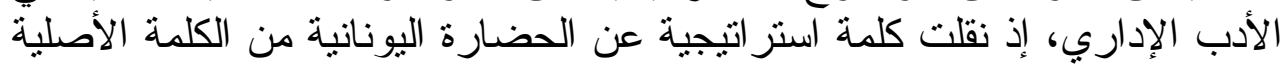

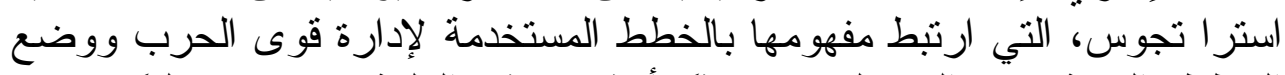

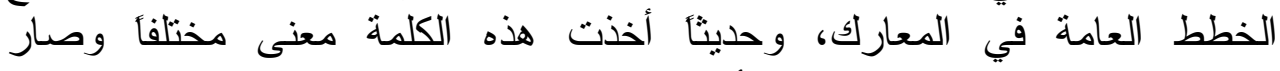
استخدامها مفضلا لدى شركات الأعمال وخاصة الحديثة الدانة منها (المغربي، 1999، 
أي أن نشوء هذا المصطلح كانت بداياته في المؤسسات الكبيرة العامة المتميزة بأهميتها السياسية والاجتماعية وهي المؤسسة العسكرية (الزيدي، 2000،

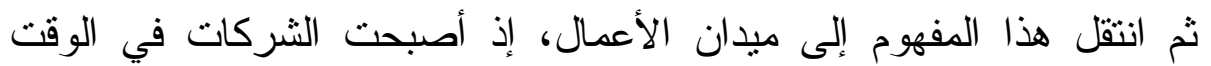

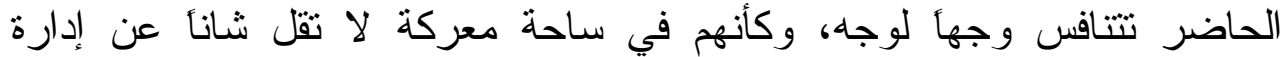

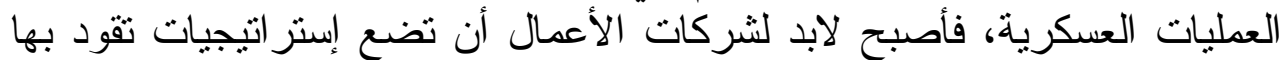

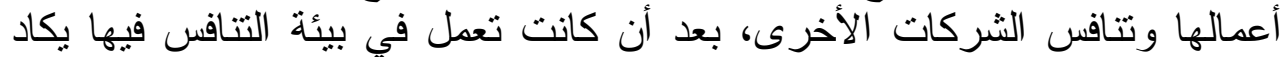

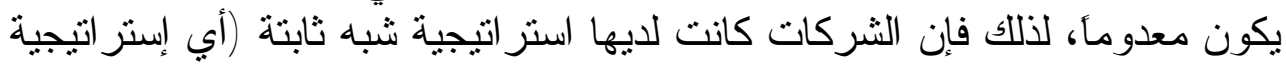

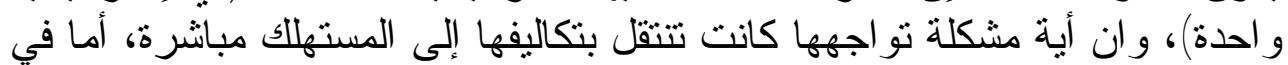
ظل المنافسة الحديثة فقد أصبحت الثركات الثرات تقام منتجات عالية الجودة بأسعار

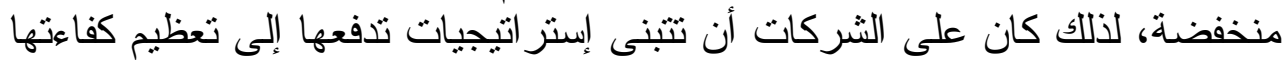

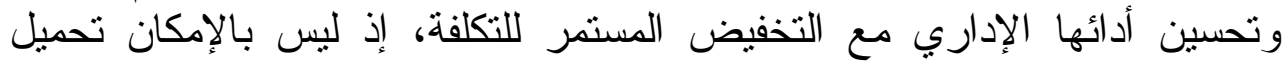

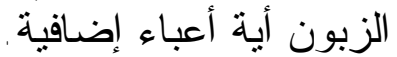

\section{Strategy Concept}

ثانياً - مفهوم الإستر اتيجية

إن كلمة (Strategy) مشتقة من الكلمتين الإغريقيتين (Strates)، وتعني الجيش الجيش

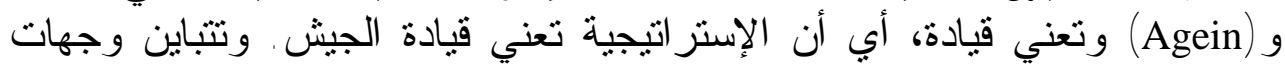

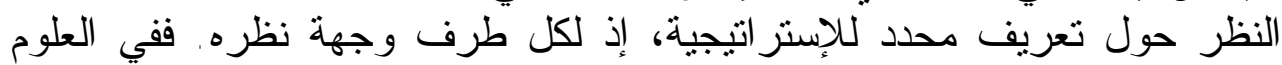

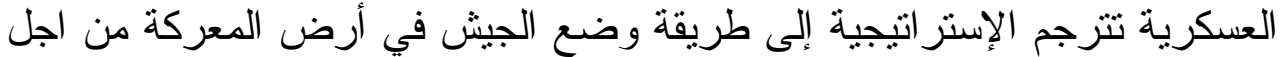

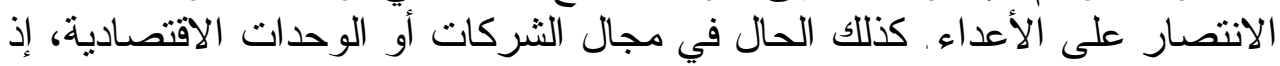

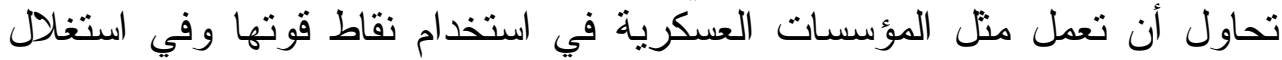

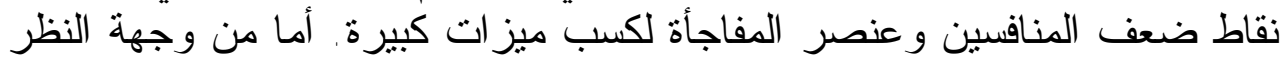

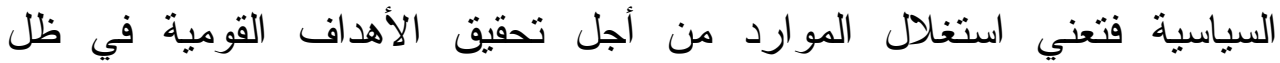

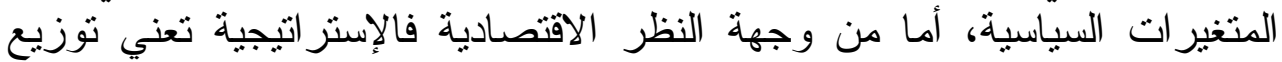

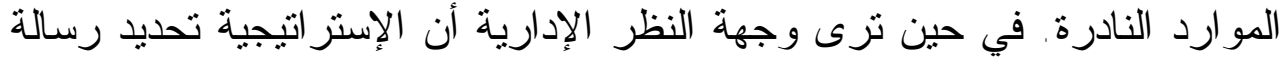

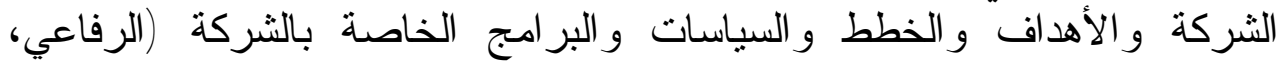

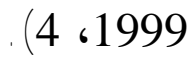

وقد عدها آخرون بأنها "خطة طويلة المدى لبلوغ أهداف المنظمة".

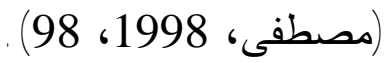
من الناحية اللغوية عرفت الإستراتيجية بأنها "علم أو فن الحرب ووضع

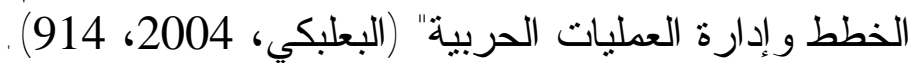

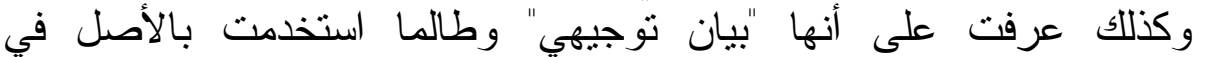

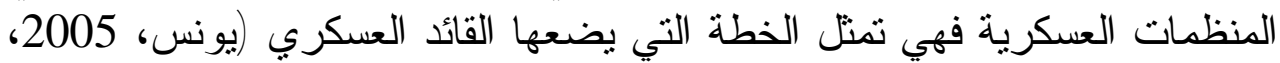


ويرى الباحثان أن الإستر اتيجية دن وجهة النظر المحاسبية هي الخطة التي التياني بموجبها يتم تسجيل وتحليل البيانات و عرضها بالثكل الذي يلائئ متطلبات الإدارة و التي تؤدي بالنتيجة إلى الآتي:

1. تعظيم دور الثركة في ظل منافسة السوق من حيث ضمان فان استمر اريتها. 2. تقديم معلومات محاسبية حول إنتاج منتجات أو تقديم خدمات ذات دمات مستوى جودة

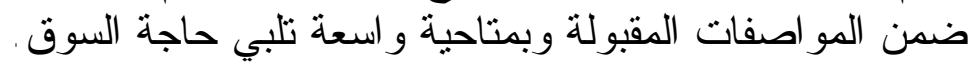
3. البحث عن أساليب أو طر ائق تسهم بشكل فعّال في التخفيض الحقي حقيقي و المستمر للكلفة.

\section{ثالثاً - فو ائد تبني إستر اتيجية معينة}

من أهم المزايا التي تحققها الثركة بتبني إستراتيجية معينة هو الآتي:

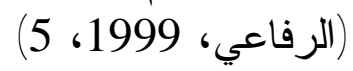

1. الاستخدام الأفضل للمو ارد المتاحة. 2. القدرة على التجاوب مع الظروف البيائية المختلفة. 3. توفير المعيار الذي يمكن استخدامه في اتخاذ القرار الفئ المناسب.

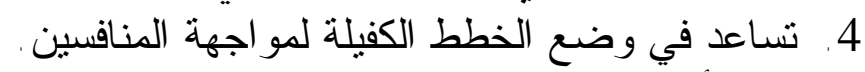

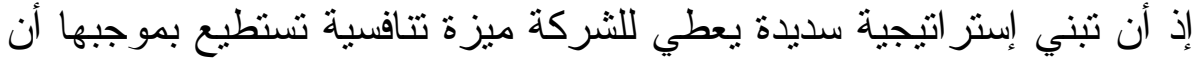

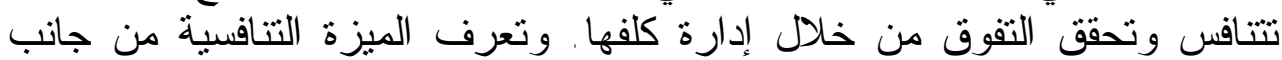

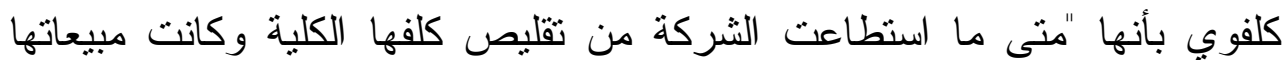

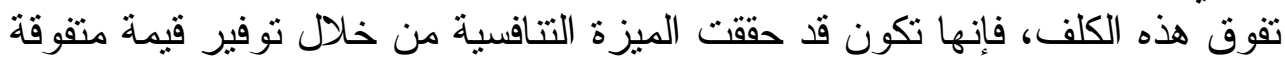

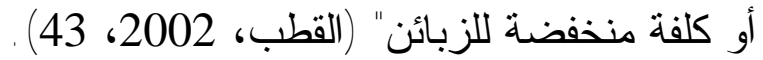

حيث أن تحقيق المبزة التتافسية ينطلب من الثركة وضع التح الاستراتيجيات

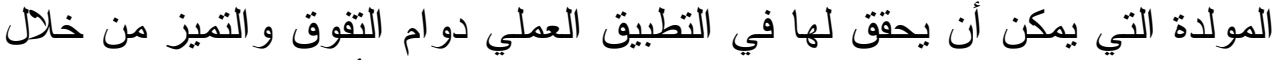

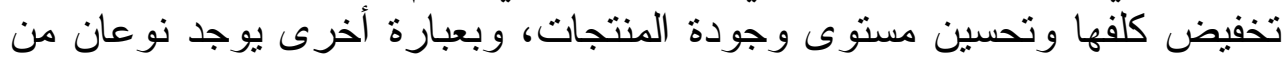
هذه الاستر اتيجيات التي تهدف عادة إلى الريادة في الكلف و الجودة المطلوبة الكية وهي

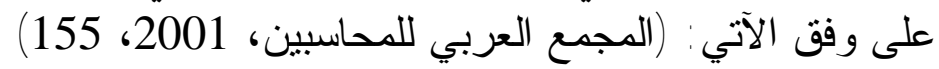

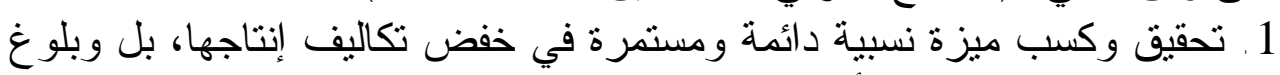

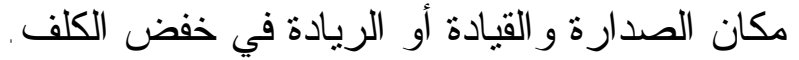
2. تحقيق وكسب ميزة نسبية دائمة ومستمرة في رفي رفع وتحسين مستوى جودة العية

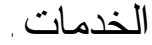

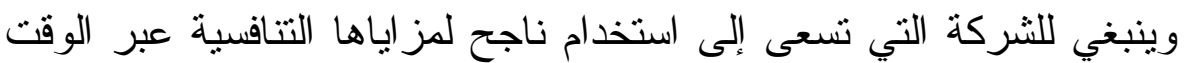

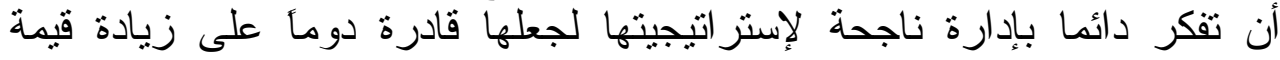
الثركة، لذلك عليها أن تتبنى إستر اتيجية تنافسية محددة. 
ماهية إدارة التكلفة وأهميتها

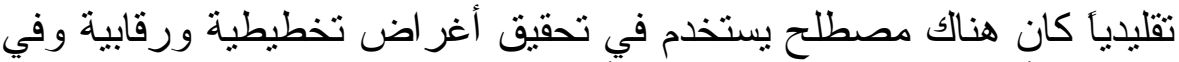

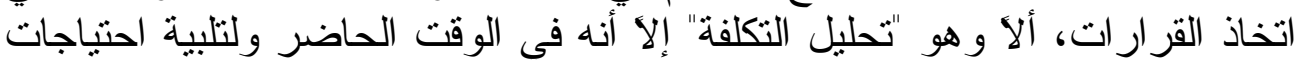

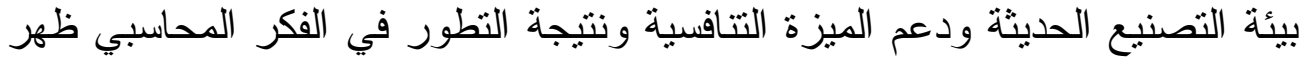

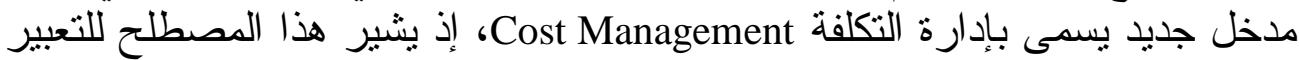

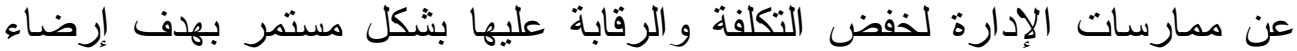
زبائنها. ولغرض تسليط الضوء على إدارة التكلفة فقد نم تقسيم المحور على بلى وفق التقاء

\section{Cost Management Concept} أولاً - مفهوم إدارة التكلفة

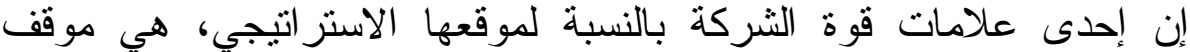

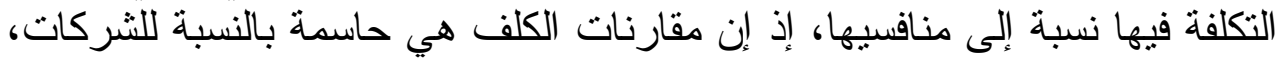
إذ يكون التتافس السعري سائداً وتكون الغلبة للثركات ذات ذات التكلفة الأدنى. (Johunson, et. al., 1993, 92)

وتمثل إدارة التكلفة إحدى الدداخل الحديثة للمحاسبة الإدارية، إذ يكون دورها

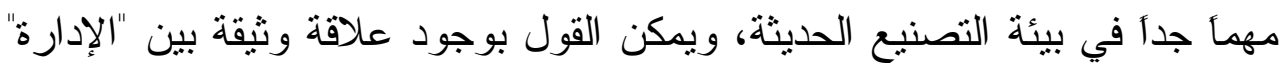

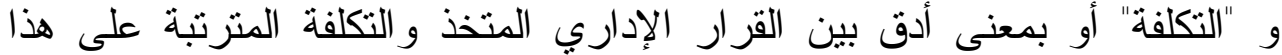

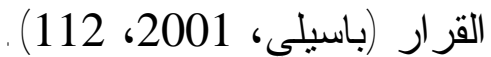

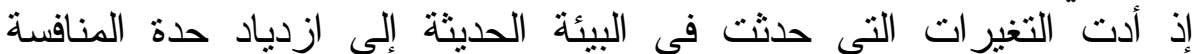

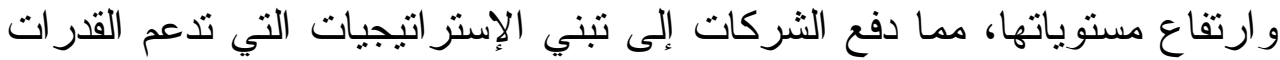

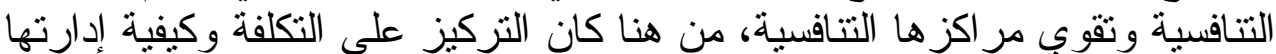

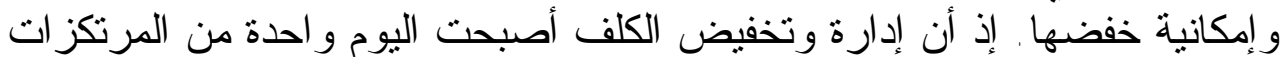

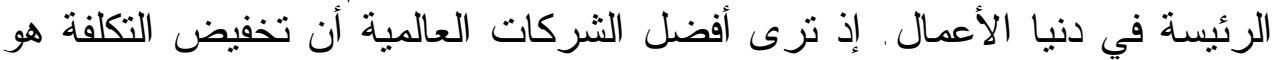

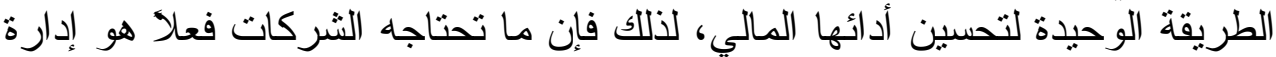
تكاليفها (الدقاف، 2004، وعليه ظهر في الآونة الأخيرة مصطلح إدارة التكلفة بشكل و اسع في شركات الإن الإنة

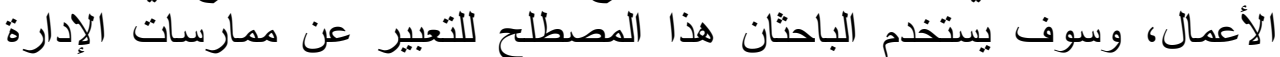

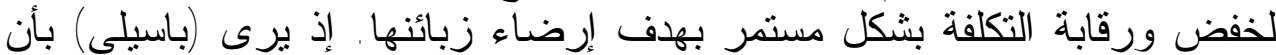

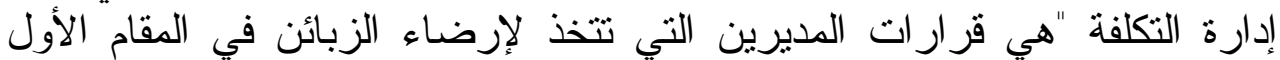

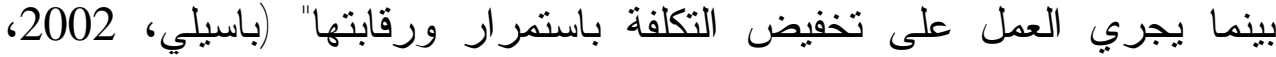

في حين برى آخرون بأنها "مجموعة الأعمال التي تتخذها الإدارة لإرضاء الإنهاء

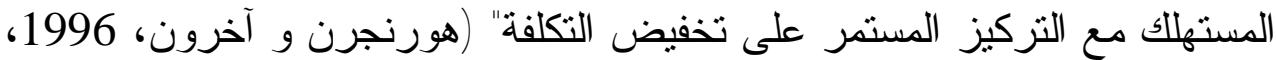

أما (بوجر وآخرون) فيرون بأن إدارة التكلفة هي "مفهوم واسع ينم فيه

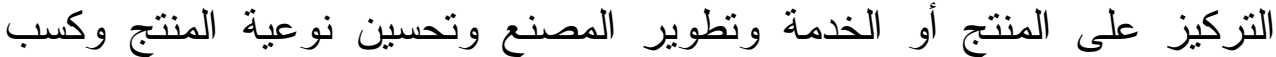
رضا الزبون" (Biocher, et. al., 1999, 3) . في حين يرى (Drury) بأن إدارة 
التكلفة هي "تلك الأفعال أو الأنشطة التي ينجز ها المدر اء لتخفيض الكلف بدلا من

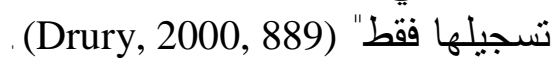
فيما يرى الباحثان أن إدارة التكلفة هي كل الجهود الر امية إلى تخفيض تكلفة

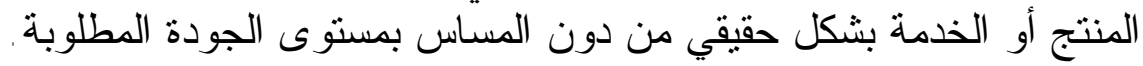

Cost Management Importance

ثانياً - أهمية إدارة التكلفة

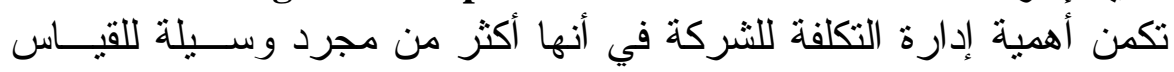

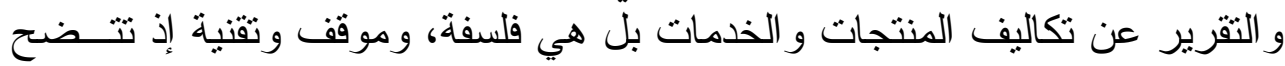

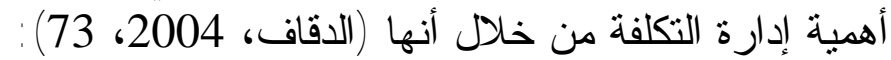

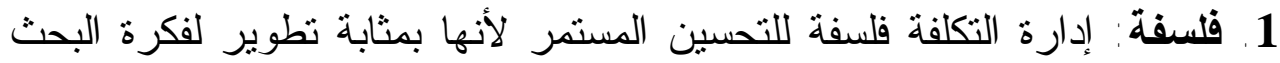

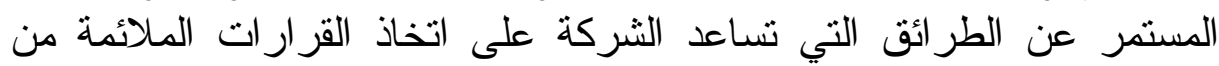

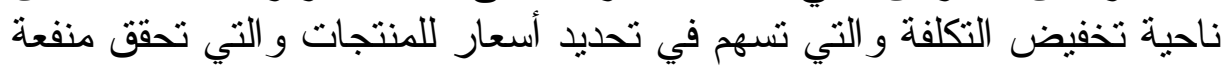

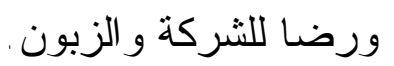

2. موقف: إن إدارة التكلفة موقف مسبق ومبادر من أن التكلفة الكلية للمنتجات

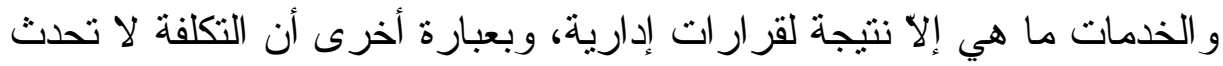

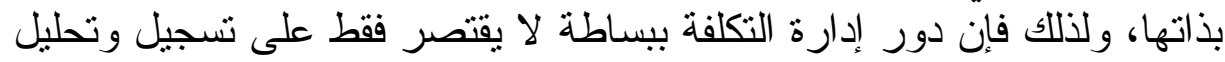

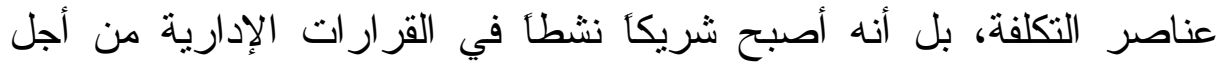
تحسين وتطوير المنتجات و الخدمات وتخفيض التهبر التكلفة.

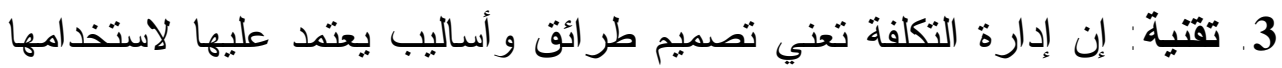

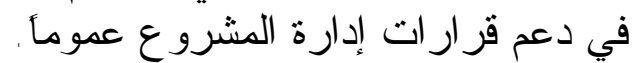

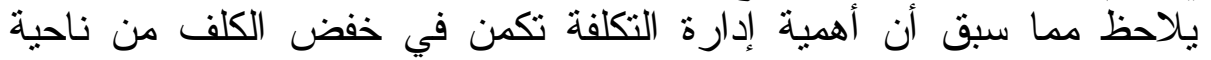

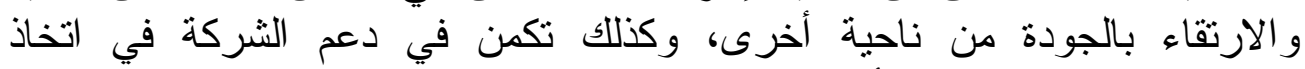
القرار ات المهمة من ناحية أخرى.

\section{Cost Management Objectives}

ثالثاً - أهداف إدارة التكلفة

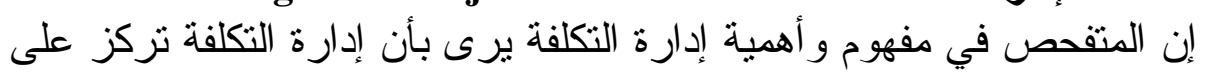
هدفين مهمين جدأ (و إن كانت هناك أهداف ثانوية أخرى) و وهذان الهدفان هما:

\section{Costs reducing}

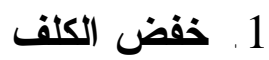

لاشك أن موضوع خفض التكلفة من الموضو عات التي تنتحوذ على اهتمام

الإدارة إذ إن تخفيض تكلفة الإنتاج إلى أدنى حد مدكن لان لان بد من أن يؤدي إلى زيلى زيادة

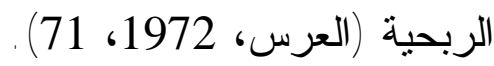

و أن أهمية خفض التكلفة تتتج من أن أية شركة هدفها الأساس هو التحكم

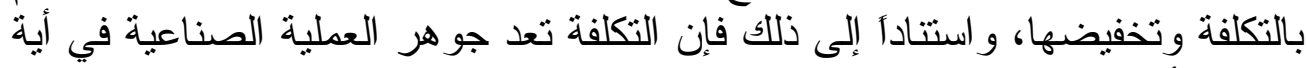

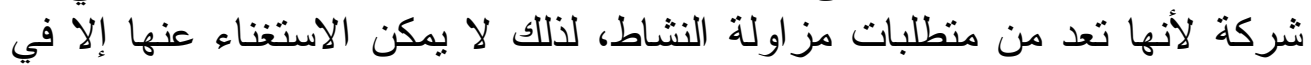

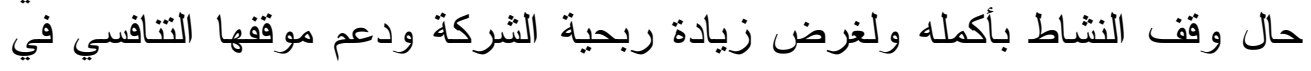




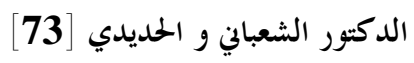

السوق نم اللجوء إلى خفض هذه التكلفة قدر الإمكان من دون المساس بجودة المنتج

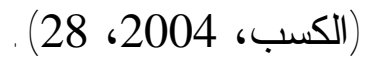

إذ أن مفهوم خفض التكلفة وإن كان يختلف في التعبير من كاتب إلى آخر إلا إلى

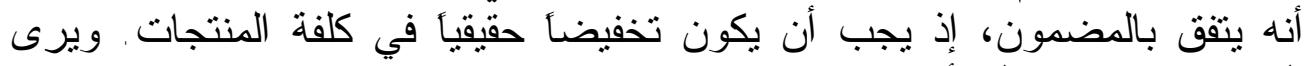

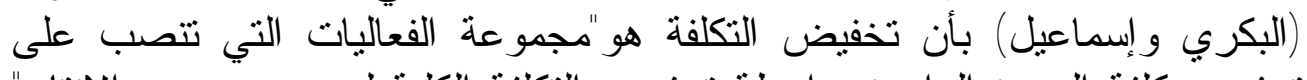

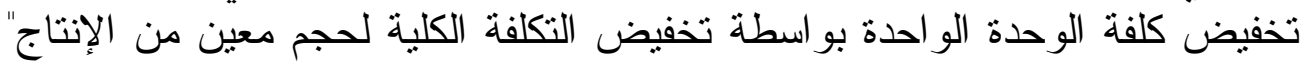

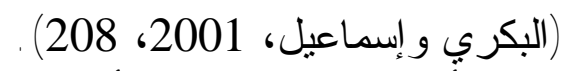
أما (إبراهيم) فيرى أن التخفيض هو "تخفيض حقيقي ودائمي على كلفة المنتجات التي تتعامل بها المنشآت بشرط بقاء مستوى الجودة على حالّه" (إبر اهيم،

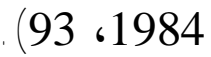

ويرى الثيخ تخفيض التكلفة على أنه "محاولة لجعل التكلفة في أدنى مستوى

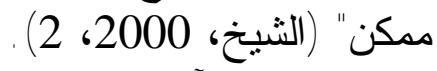
ويركز آخرون على أن تخفيض التكلفة يتطلب دائما تحدي المعايير وعلى فئى

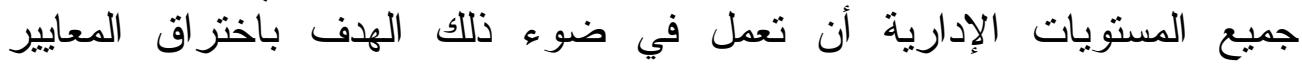

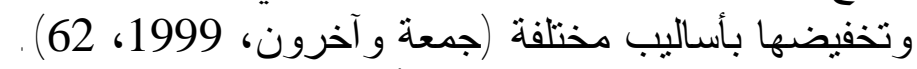

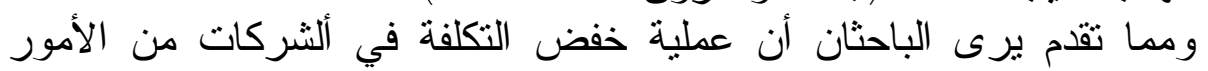

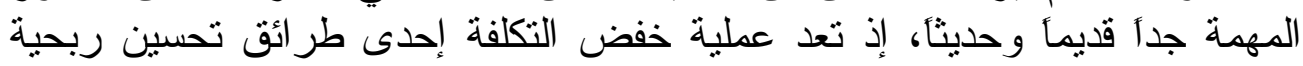

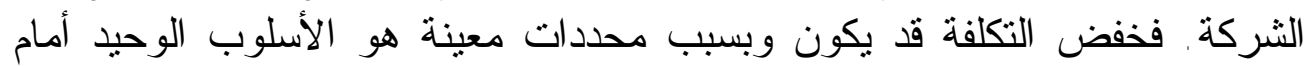

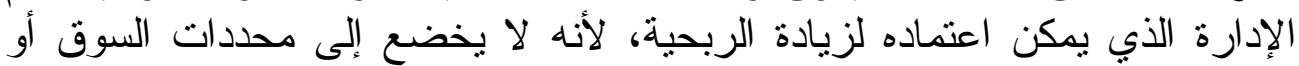
ويرى (الجزار) بأن تخفيض التكلفة يتم عن طريق عاملين هما (الجزار،

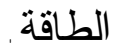

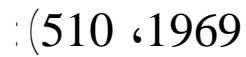
أ. تخفيض تكلفة الوحدة من المنتج بتخفيض كلف الإنتاج في ضوء حجم معين من النشاط.

ب. تخفيض تكلفة الوحدة من المنتج بزيادة الإنتاجية في ضوء حجم نفقات كنقات معينة.

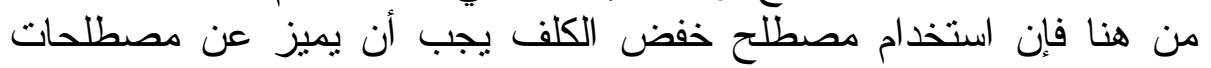
متداخلة عدة معه مثنال النغان 1. التمييز بين خفض التكلفة و الرقابة على التكلفة. 2. التمييز بين خفض التكلفة الحقيقي وخفض التفلين التكلفة الوهي.

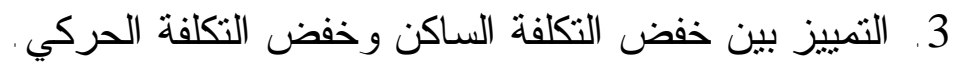
4. التمييز بين خفض التكلفة وتجنب التكلفة. إذ يجب التمييز بين خفض التكلفة وبين الرقابة على التكلفة، وان كان الان الاثنان

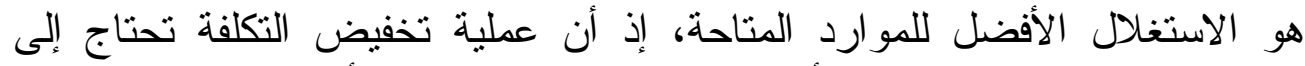
استر اتيجيات فعالة تختلف عن أساليب الرقابة على الإلى التكلفة، لأن الرقابة التهابة على التكلفة هي وضع نظم رقابية على عمليات ونشاطات الثركة بهدف تحسين الألئ لأداء من خلال 
متابعة الفروقات (من خلال وضع معيار ثم متابعة الفعلي و المقارنة بين الفعلي

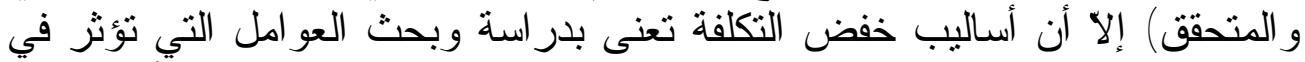
التكلفة و التغيرات و الانتقال من المستوى الحالي للتكاليف إلى مستوى ألى أدنى منها،

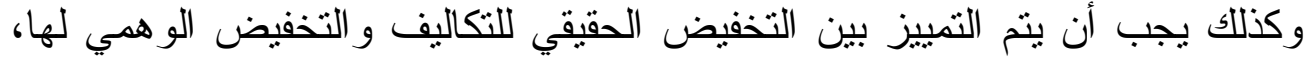

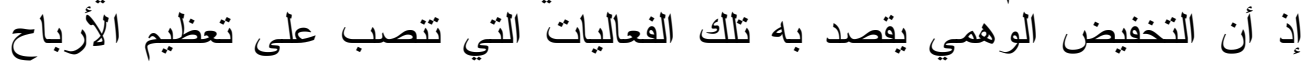

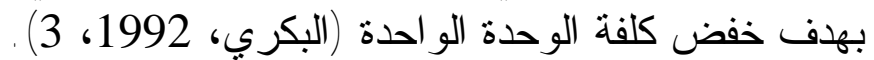

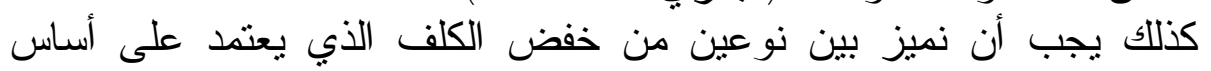

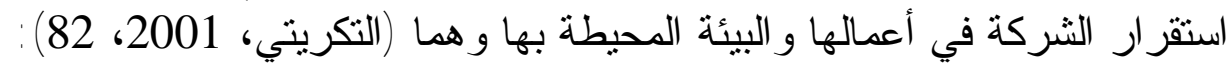

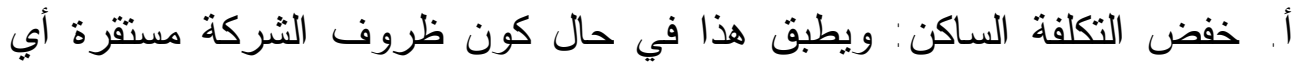

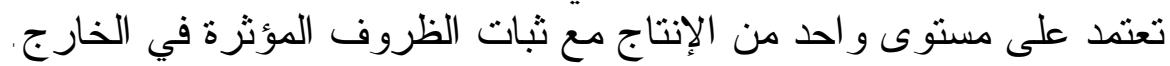

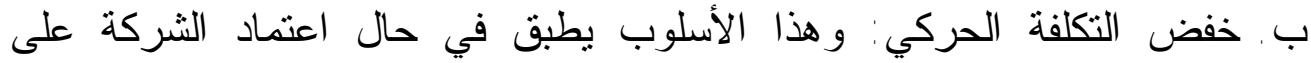

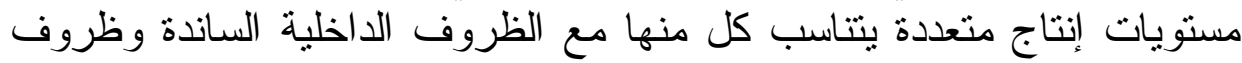
السوق المحيطة.

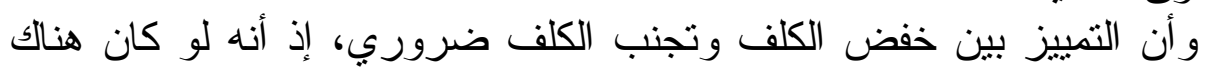

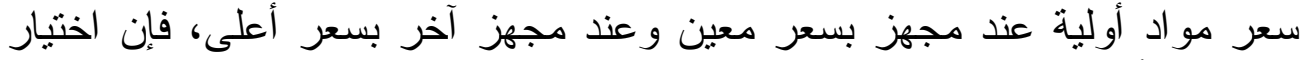

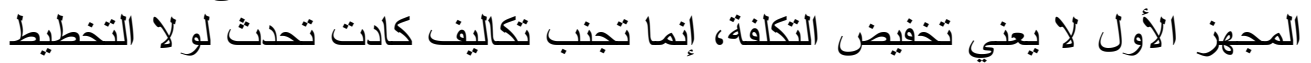

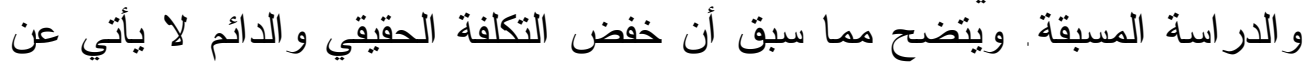

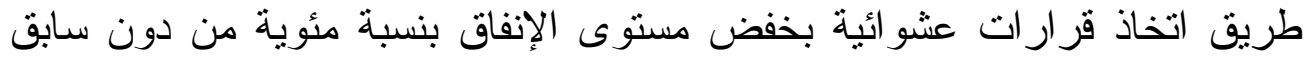

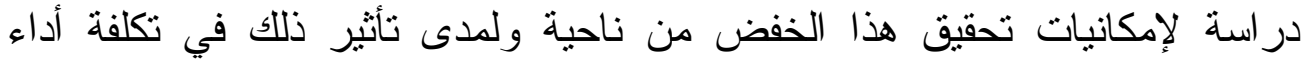
النشاط من ناحية ثانية، و على فاعليته وكفاءته من ناحية ثالثة (الجبر و ولئ عبد العزيز ،

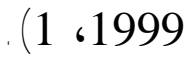
و عليه برى الباحثان أن خفض الكلف يعد أحد أهداف الإستر اتيجيات المهمة

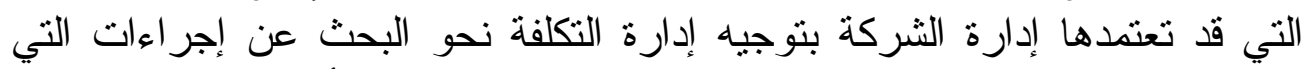

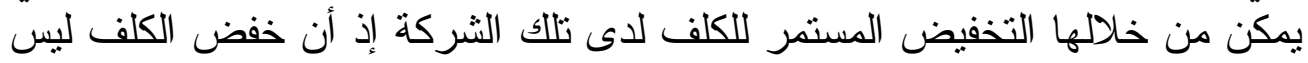

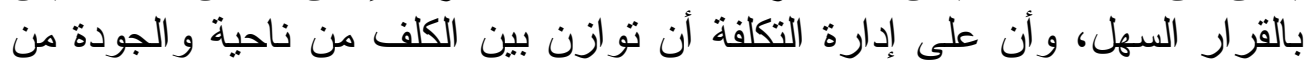

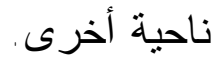
وقد أثرت التطورات في مجال التصنيع على هيكل التكلفة، ففي السبعينات

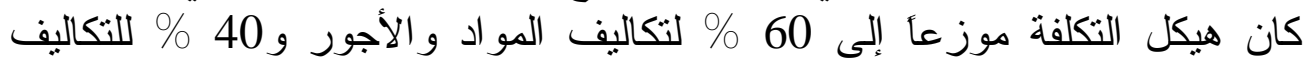

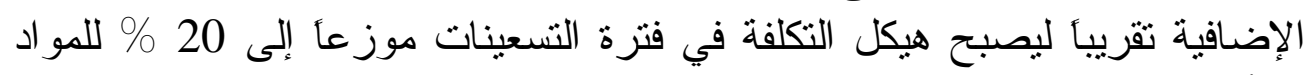

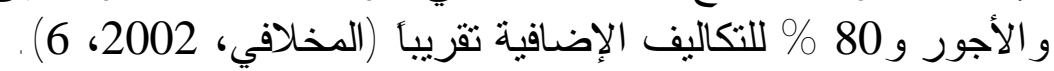

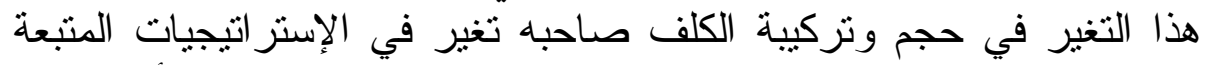

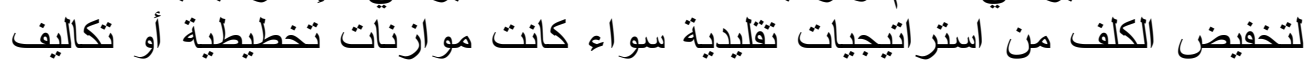

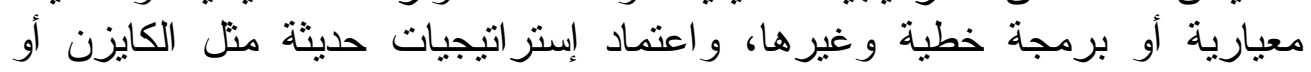
تحليلات هندسة القيمة أو إدارة الجودة الثناملة، أو التكلفة المستهدفة ولثئة وغير ها.

$$
\text { Quality الجودة } 2
$$


الجودة بشكل عام تعني بأن المنتج أو الخدمة يجب أن تلبي رغبة المستهلك

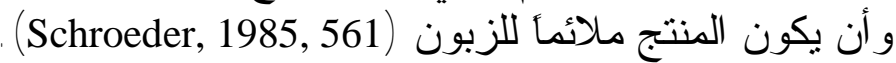

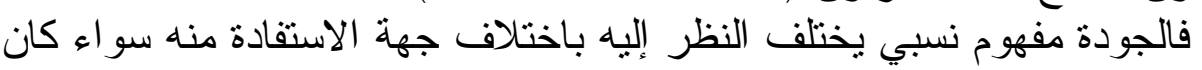

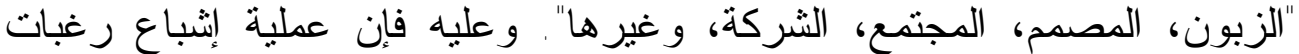

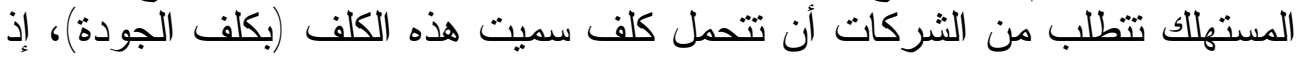

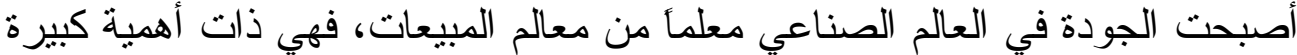

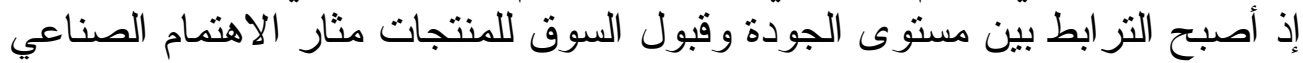

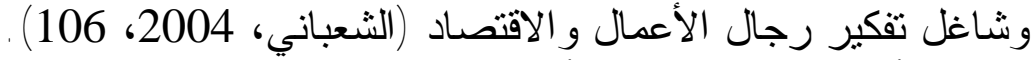

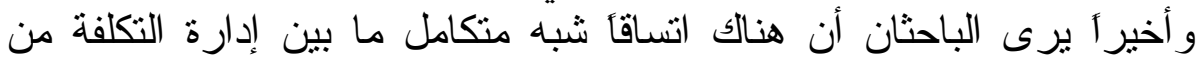

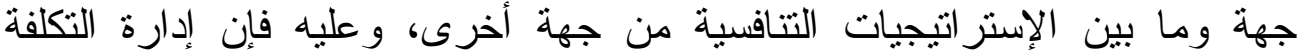

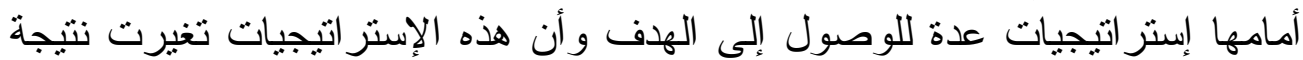

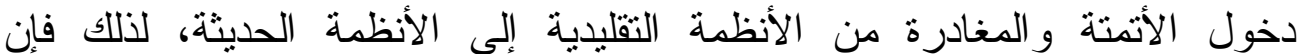

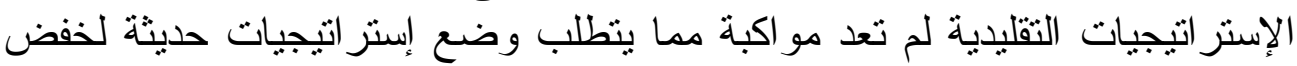
الكلف تتو اكب مع التغير ات التكنولوجية.

\section{Cost Reduction Strategies}

إستراتيجيات خفض الكلف مهما تعددت الإستراتيجيات إلا أنه يبقى الهدف واحدأ وهو خفض التهيت التكلفة، وتقليدياً فقد اعتمدت إستراتيجيات عدة منها إستراتيجيات محاسبة الكلف: Cost Accounting Strategies التخطيطية وطريقة التكلفة الكلية أو الإجمالية وطريقة التكلفة المتغيرة ومخططات التئية

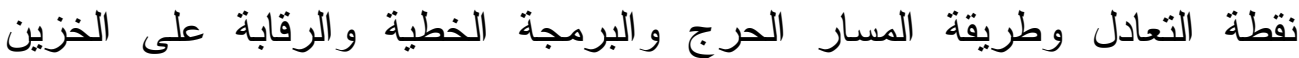

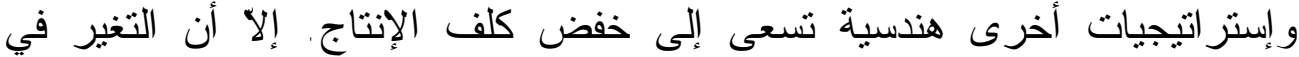
الأنظمة الإنتاجية أدى إلى تغير تركيبة كلف الإنتاج و عليه أصبحت الأنساجئ الأنمة الكلفوية

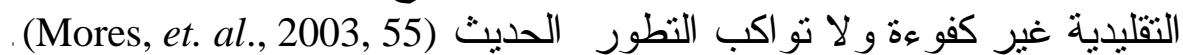

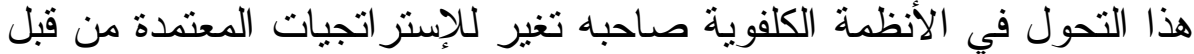

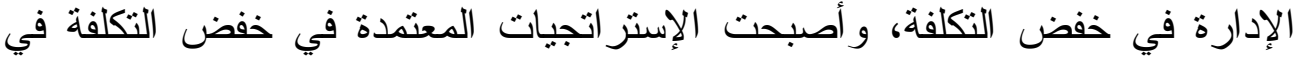

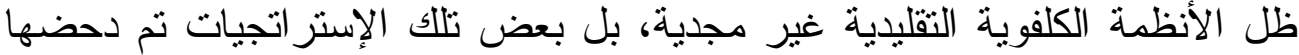

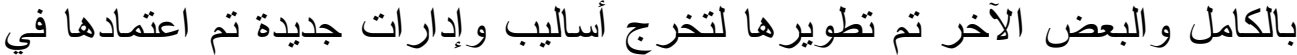

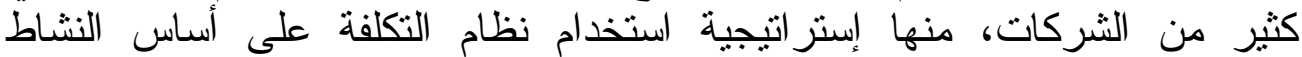
و وإستر اتيجية استخدام نظام كلفة التدفق التقام (Activity-Based Costing Strategy) الارتجاعي (Back Flush Strategy) و وإستر اتيجية استخدام إدارة التكلفة المستهدفة

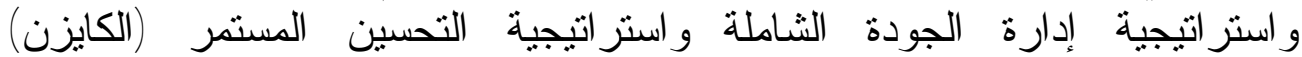
و إستراتيجية تحليلات هندسة القيمة وسيتم التركيز على الإنية الإستراتيجية الأخيرة بوصفها الإستر اتيجية المنتخبة للنطبيق في عينة البحثة

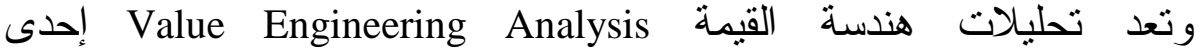
الإستر اتجيات المهمة لإدارة التكلفة التي تتوقف عليها إستر اتجيات عدة أخرى و هناك 
مصطلحات متقاربة ولكن لكل واحد معنى، إذ تتاول العديد من الباحثين موضوع الإنى

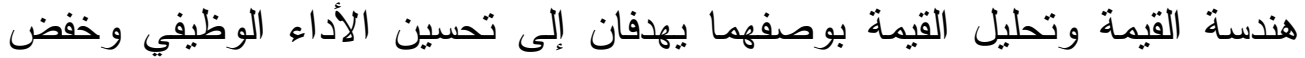

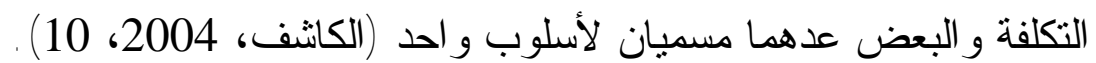

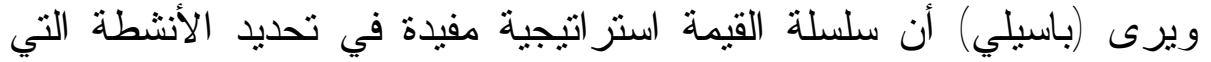
تضيف قيمة و الأنشطة التي لا تضيف قيمة داخل منظمة الأعمال . (باسيلي، 2002،

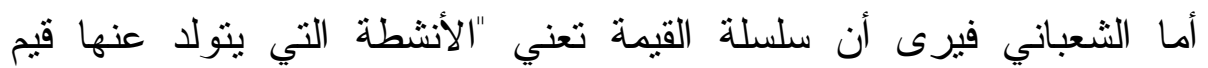
مضافة امتدادأ من المو اد الخام الأساسية وصو لا إلى المستهلك النهانية النهائي" (الثعباني، . 2005 ويرتكز مفهوم سلسلة القيمة على محورين رئيسين وهما (باسيلي، 2001، أ. تحديد الأشطة التي تضيف قيمة: وهي تلاك الأنشطة التي يقتتع المستهلكون أنها

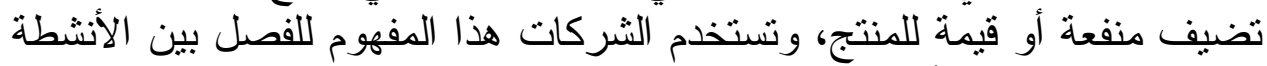

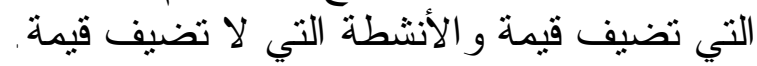

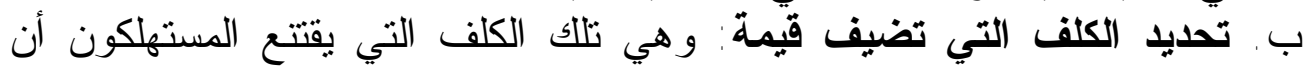

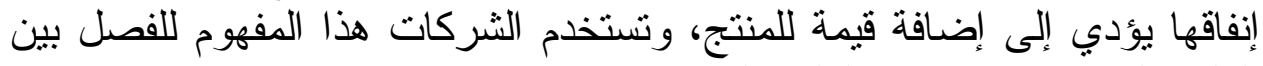

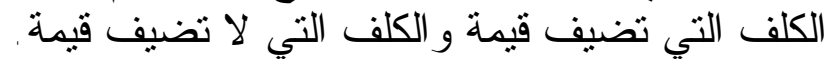
ويلاحظ أن العلاقة بين سلسلة القيمة وتحليل القيمة متداخلة إذ اتضحح مما تقام

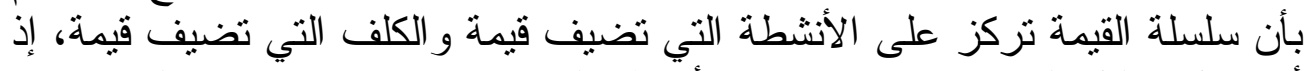
أن عمل تحليل القيمة يكون في تتمية الأنشطة التي تضيف قليفة قيمة و الإبقاء عليها و إبعاد الأنشطة الني لا تضيف قيمة وكذلك فيك الحال بالنسبة للتكاليف. وعليه يرى (باسيلي) أن تحليل القيمة أداة علمية منظمة تعمل بصفة دائمة لإنة لتحسين

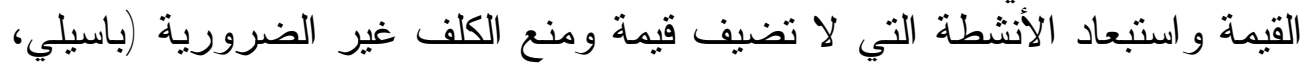

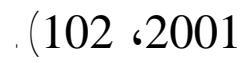

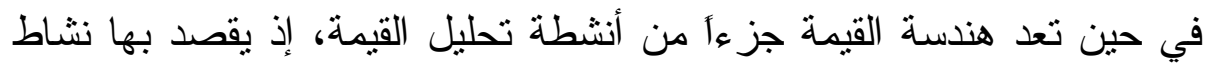

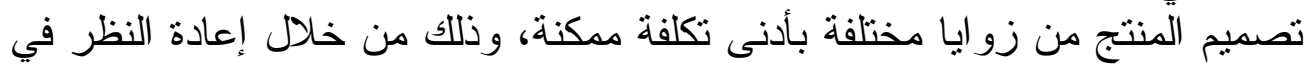

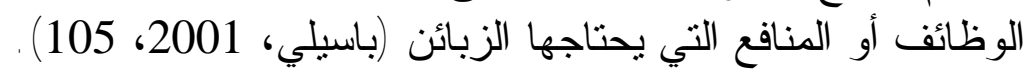

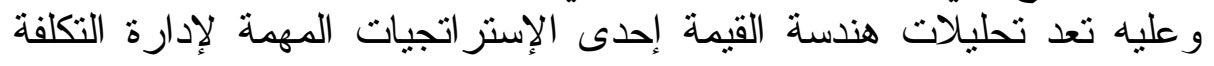

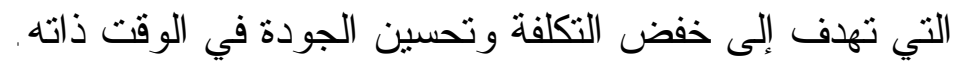

نبنويق سلسلة القيمة على الثركة اكز والمسارات التكنة لصناعة الأدوية والمستلزمات الطبية في

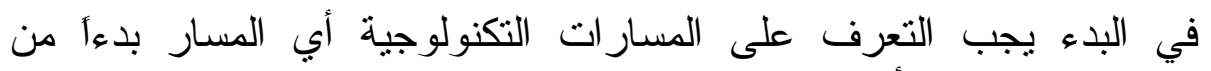
الحصول على المواد الأولية وانتهاءً بالمنتج التام التي في ضولئهئها ينت تحديد 
الدكتور الشعباني و الحديدي [77]

الأنشطة، حيث أن المتقحص للمسارات التكنولوجية يرى أن هناك تقارباً في

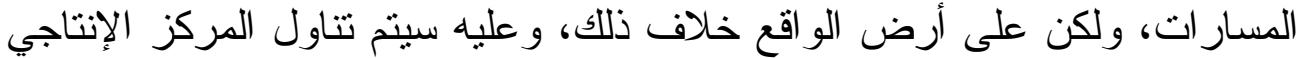
الأول هو قسم الحبوب والكبسولاته، إذ إذ يعد هذا القسم من أضخم الأقسام الإنتاجية

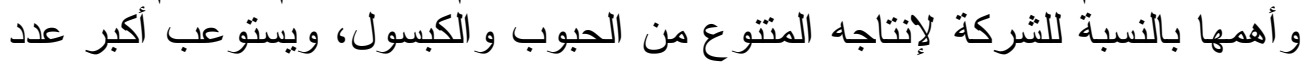
من العاملين قياساً إلى باقي الأقسام ويكون مساره التكنولوني لوني كما في الثكل 1:

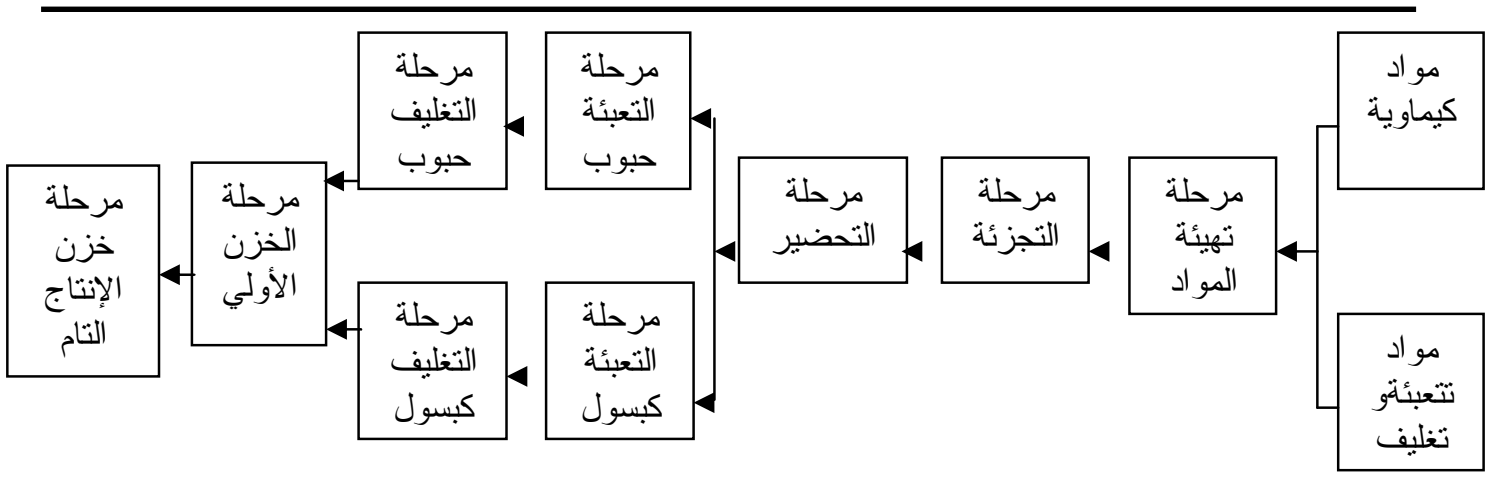

\section{الشكل 1}

المسار التكنولوجي لقسم الحبوب والكبسولات

المصدر : حمودي، 2006، 69.

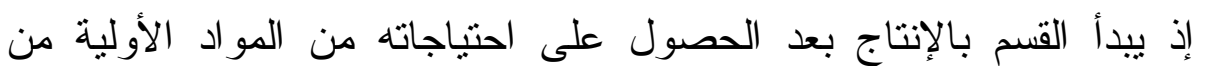

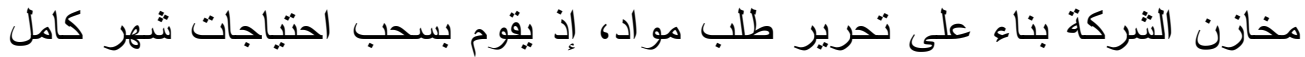

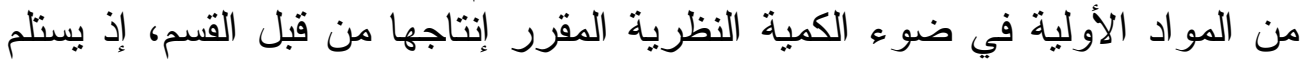

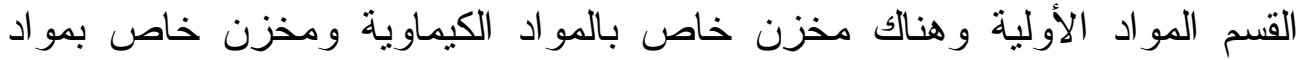
التعبئة والتغليف داخل القسم، وبعد أن تتم مرحلة تهيئة المواد الأولية تبدأ عملية التجزئة، إذ تختلف التركيبات على وفق نوع التهو الحب أو الكبسول وتكون التجزئة

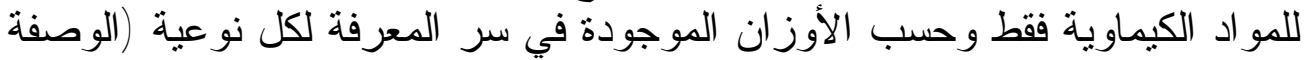

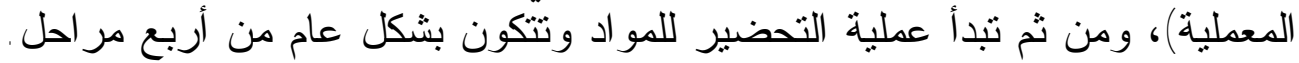

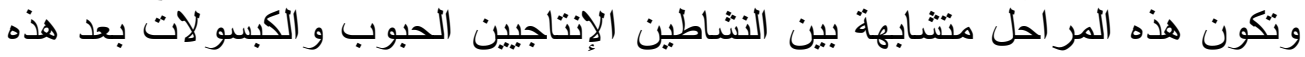

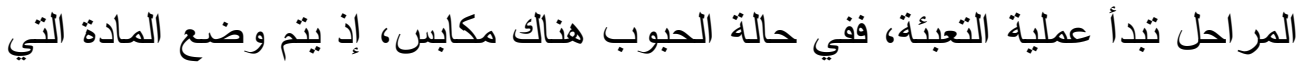

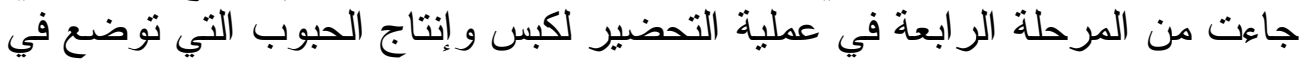

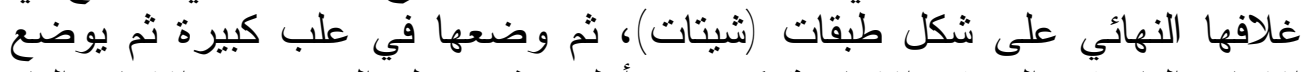

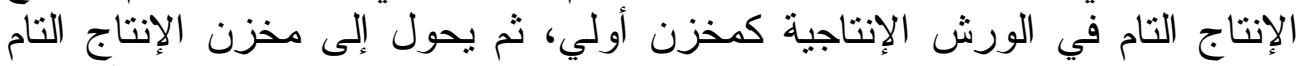
داخل القسم الإنتاجي ومن بعدها يرحل إلى الإنى مخزن الإنتاج التام الرئيس (مخازن

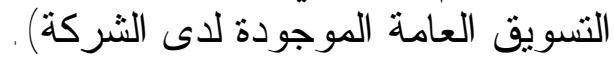




\section{بطاقة كلفة خاصة بقسم الحبوب}

\begin{tabular}{|c|c|c|c|c|c|c|c|}
\hline عنداصة الوحدةً من & القَّيمة & للاعر المادة & الكمية & 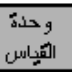 & الرَتم الرمزي & السم المـادة & $\Xi$ \\
\hline 0.004955 & 4954.8 & 12.387 & 400 & KG & 50549 & Sulfamethazole & 1 \\
\hline 0.014909 & 14908.8 & 186.36 & 80 & KG & 51906 & Trimethoprim & 2 \\
\hline 0.010197 & 10197.414 & 1699.57 & 6 & $\mathrm{KG}$ & 50537 & P.V.P & 3 \\
\hline 0.001685 & 1684.8992 & 2106.12 & 0.8 & $\mathrm{KG}$ & 50537 & Sodium Lauryl Sulfate & 4 \\
\hline 0.027877 & 27876.7107 & 637.911 & 43.7 & $\mathrm{KG}$ & 50519 & Maize Starch & 5 \\
\hline 0.004790 & 4789.55 & 957.91 & 5 & $\mathrm{KG}$ & 50551 & Talc & 6 \\
\hline 0.015642 & 15642.46 & 3128.49 & 5 & $\mathrm{KG}$ & 50303 & Magnesium Stearate & 7 \\
\hline 0.001207 & 120368 & 3018.42 & 0.4 & $\mathrm{KG}$ & 50314 & M.H.B & 8 \\
\hline 0.000001 & 1.0976 & 5.488 & 0.2 & $\mathrm{KG}$ & 50445 & P.H.B & 9 \\
\hline 0.08 & 81263.0995 & 11752.661 & 541.1 & \multicolumn{4}{|c|}{ اجمالي المو اد الكيكاوية } \\
\hline 0.4 & & & & & & |ألمثيوت & 1 \\
\hline 0.6 & & & & & & p.v.c & 2 \\
\hline 0.2 & & & & & & لييلن & 3 \\
\hline 0.5 & & & & & & الباكيت & 4 \\
\hline \multirow[t]{4}{*}{1.7} & 0 & \multicolumn{6}{|c|}{ 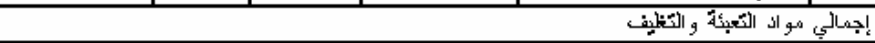 } \\
\hline & 0.08 & \multicolumn{5}{|c|}{ الدو اذد الكِيداوية } & + \\
\hline & 1.7 & \multirow{2}{*}{\multicolumn{5}{|c|}{ 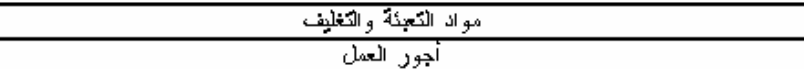 }} & - \\
\hline & 2.7 & & & & & & + \\
\hline 4.48 & & \multicolumn{5}{|c|}{ كلفة لنَصنيخ } & +\% \\
\hline & & & & & & & \\
\hline 2.84 & \multicolumn{6}{|c|}{ التَكاليف نُير الهجانشرة } & + \\
\hline 7.32 & \multirow{2}{*}{\multicolumn{6}{|c|}{ 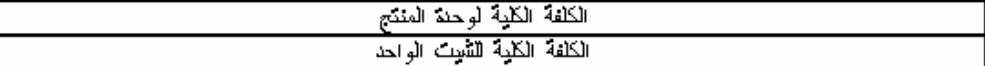 }} & $\& \&$ \\
\hline 73.2 & & & & & & & $\& \&$ \\
\hline
\end{tabular}

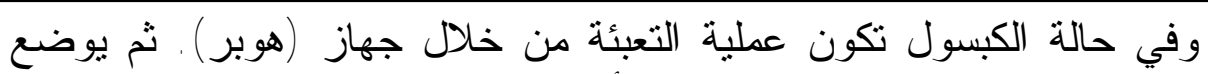

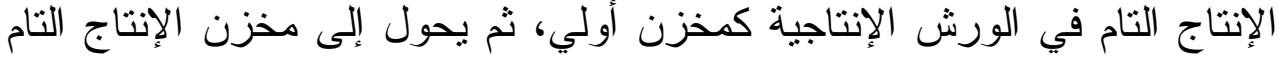
داخل القسم الإنتاجي ومن بعدها يرحل إلى الإنى مخازن التسويق العامة . وكذللك الحال

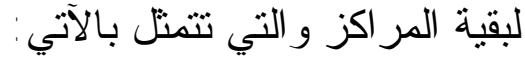
1 ـ المركز الإنتاجي الثاني قسم المر اهم و الكريمات والاتي و التحاميل .

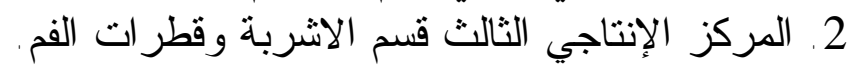
3. المركز الإنتاجي الر ابع قسم قطر ات التاجي العيون.

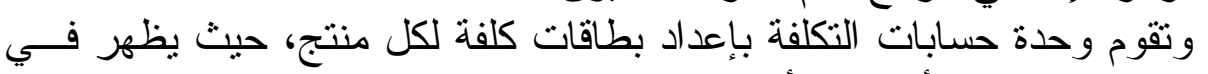

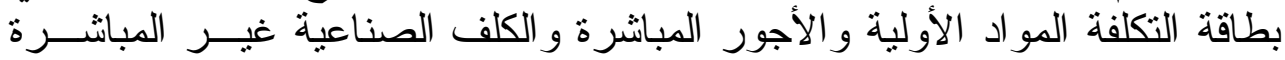

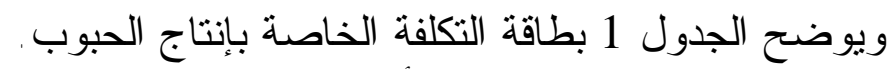
وكذلك الحال في بقية الأقسام حيث يتم مسك بطاقات كلف لفانف لكافة المنتجات سو اء كانت مر اهم أم أثربة أم قطر ات عيون التمام

ثاتياً - آلية احتساب كلف الإنتاج في الثركة عينة البحث 
الدكتور الشعباني و الحديدي [79]

تعتمد الثركة على نظام الأوامر الإنتاجية في عملها وعلى وفق النظرية

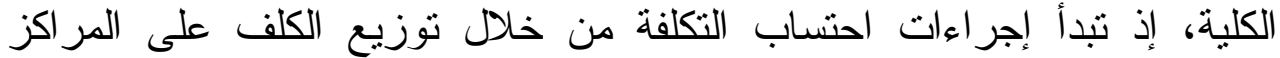

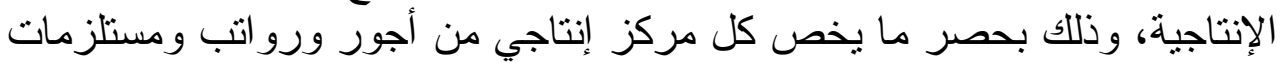

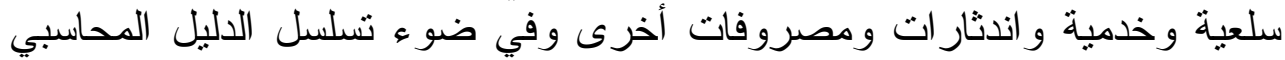

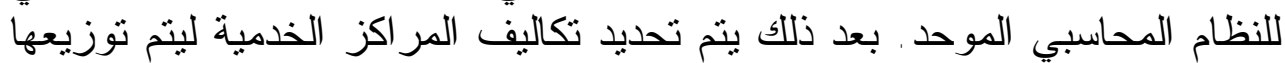

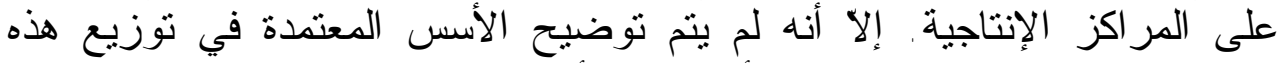

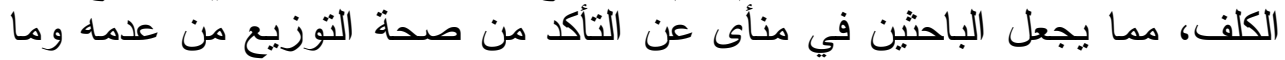
ينعكس من آثار على كلفة الوحدة المنتجة.

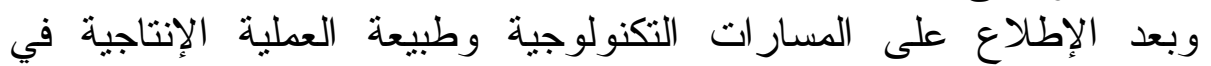
الثركة يرى الباحثان أن هنالك أكثر من إستر اتيجية يمكن اعتمادها في الثركة الثركة

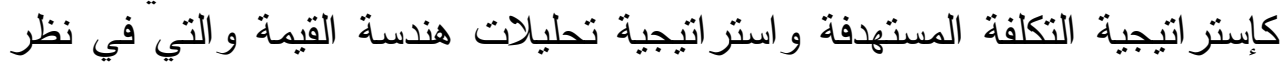

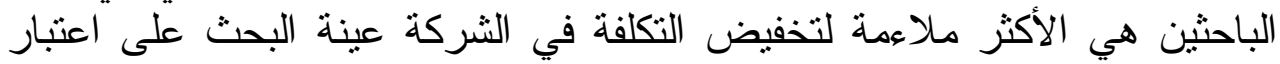

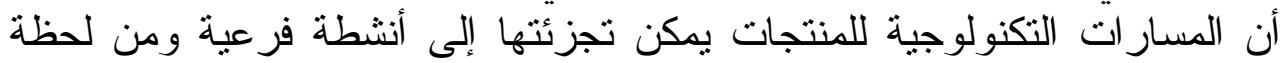

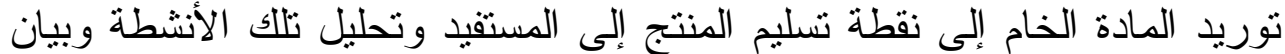

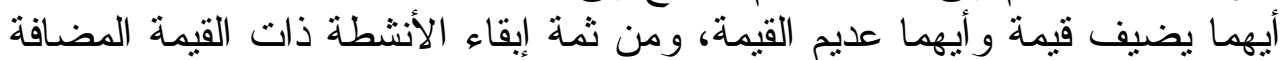

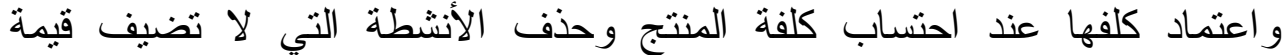
و التخلص من كلفها و وعليه سيتم تتاول هذا التطبيق من خلال جانبين وكالآتي:

\section{الجانب الأول - كلف الأشطة الرئيسة قبل التطبيق}

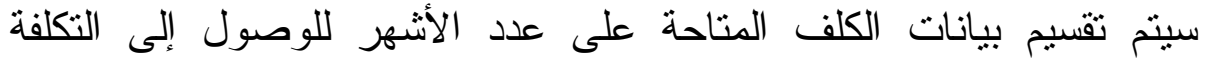

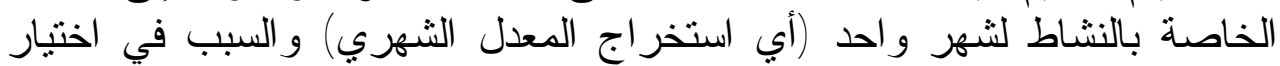

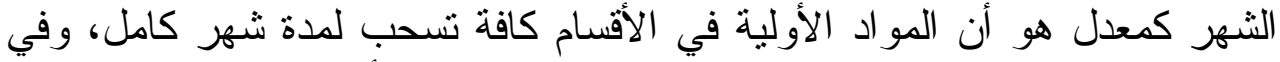

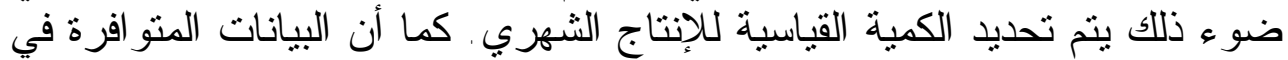

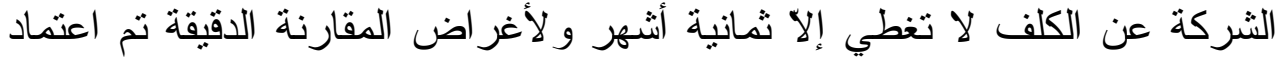
البيانات بوصفها معدلا شهريأ، وعليه فإن كلف الأنشطة نقليدياً تكون بالثكل

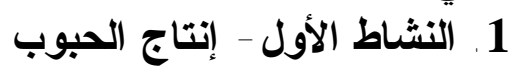

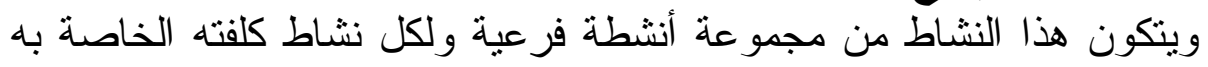

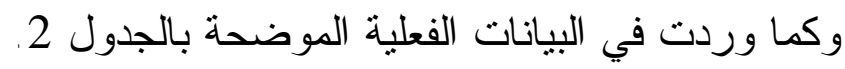




\begin{tabular}{|c|c|c|}
\hline بالغ بالدينار العر اقي) & تششاط الحبوب 2 & قائمة تكال \\
\hline \multirow[t]{5}{*}{ كلي } & جزئي & البيان \\
\hline & & كلفة المواد المباشرة: \\
\hline & 66807063.1125 & مو اد كيماوية \\
\hline & 28405307.975 & مو اد التعبئة المنداولة \\
\hline & 5415.4625 & مو اد التغليف \\
\hline 95217786.55 & & إجمالي كلفة المو اد المباشرة \\
\hline \multirow[t]{24}{*}{82142317.6875} & & كلفة العمل المباشر \\
\hline & & التكاليف الصناعية غير المباشرة: \\
\hline & 750 & مو اد نفطية \\
\hline & 2182159.175 & أدو ات احتباطية \\
\hline & 2802845.15 & ل لو ازم ومهمات \\
\hline & 241846.225 & مو اد إنشائية \\
\hline & 157331.45 & كساوي \\
\hline & 620551.6625 & مو اد غذائية \\
\hline & 904869.41 & مو اد طبية \\
\hline & 133177.2 & مياه \\
\hline & 136296.85 & كهرباء \\
\hline & 96000 & صيانة مباني وطرق \\
\hline & 985823.125 & صيانة آلات ومعدات \\
\hline & 14375 & صيانة وسائط النقل \\
\hline & 6875 & صيانة أثناث و أجهزة مكاتب \\
\hline & 87500 & خذمات أبحاث و استشار ات \\
\hline & 1330961.75 & نقل العاملين \\
\hline & 489131.4625 & سفر و إيفاد \\
\hline & 2308.3125 & مصروفات خدمية أخرى \\
\hline & 80375.4 & اندثار مباني وطرق \\
\hline & 784071.8625 & اندثار آلات ومعدات \\
\hline & 247238.075 & اندثار وسائط النقل \\
\hline & 213585.4125 & اندثار أثاث و أجهزة مكاتب \\
\hline & 987245.25 & إعانات للمنتسبين \\
\hline 12505317.77 & & إجمالي التكاليف الصناعية غير مباشرة \\
\hline 189865422.0075 & & إجمالي كلفة الصنع الشهرية \\
\hline
\end{tabular}

المصدر: من إعداد الباحثين بالاعتماد على بيانات الثركة، للفترة من 1/1 -2005/8/31 
المعدل الثهري للإنتاج الفعلي الخاص بنشاط الحبوب (26260750) حبة.

$$
\begin{aligned}
& \text { إذن كلفة الصنع للوحدة الواحدة }
\end{aligned}
$$

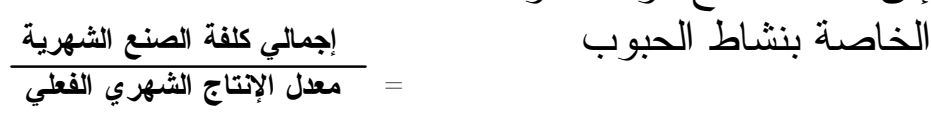

$$
\begin{aligned}
& \frac{189865422.0075}{26260750}=
\end{aligned}
$$$$
\text { إت } 7.23 \text { دينار /حبة. }
$$$$
\text { 2. النشاط الثاني - إنتاج الكبسولات }
$$

باعتماد الأسلوب السابق نفساه ستكون كلفة الوحدة المنتجة بالثنكل الآتي: المعدل الثهري للإنتاج الفعلي الخاص بنشاط الكبسو لات (9887488) كبسولة.

$$
\begin{aligned}
& \text { إذن كلفة الصنع للوحدة الواحدة }
\end{aligned}
$$

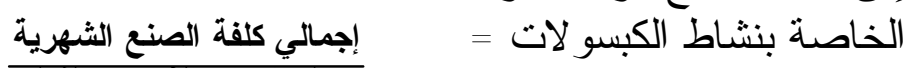

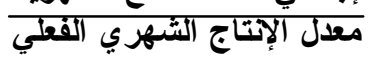

$$
\begin{aligned}
& \frac{50408503.06}{\mathbf{0 8 9 7 1 9 8}}= \\
& \text { = } 5.1 \text { دينار /كبسولة }
\end{aligned}
$$

3. النشاط الثالث - إنتاج المر اهم و الكريمات

كذلك باعتماد الأسلوب السابق نفسه ستكون كلفة الوحدة المنتجة بالثكل المعدل الثهري للإنتاج الفعلي الخاص بنشاط المر اهم و الكريمات (424420)

$$
\begin{aligned}
& \text { إذن كلفة الصنع للوحدة الواحدة }
\end{aligned}
$$

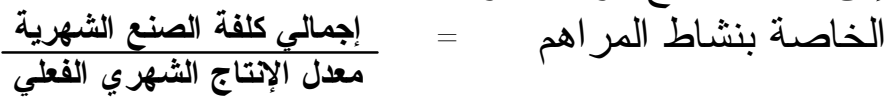

$$
\begin{aligned}
& \frac{94027583.95}{424420}= \\
& \text { 221.5 = = }
\end{aligned}
$$


باعتماد الأسلوب السابق نفسه ستكون كلفة الوحدة المنتجة بالثكل الآتي: المعدل الثهري للإنتاج الفعلي الخاص بنشاط التهاطئل التحاميل (1755625) تحميل.

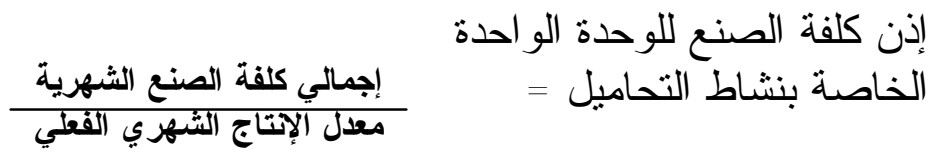

$$
\begin{aligned}
& \begin{aligned}
\frac{11267889.33}{1755625} & = \\
6.41= & =
\end{aligned}
\end{aligned}
$$

5. النشاط الخامس - إنتاج الاشربة

المعدل الثهري للإنتاج الفعلي الخاص بنشاط الإنة الشربة (467895) قنينة.

$$
\begin{aligned}
& \text { إذن كلفة الصنع للوحدة الواحدة }
\end{aligned}
$$

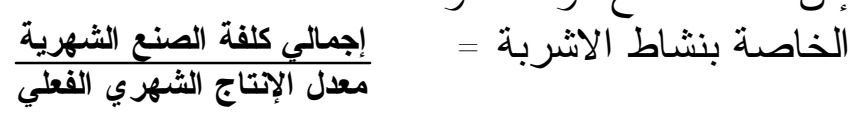

$$
\begin{aligned}
& 132998791.5= \\
& 467895
\end{aligned}
$$$$
284.25=
$$

6. النشاط السادس - إنتاج قطرات الفم

وباعتماد الأسلوب السابق نفسه ستكون كلفة الوحدة المنتجة بالثكل الآتي: المعدل الثهري للإنتاج الفعلي الخاص بنشاط قطر ات الفم الفئ (142422) قنينة.

$$
\begin{aligned}
& \text { الذاصة بلفة الصنّع للوحدة الواحدة } \\
& 30136442.03= \\
& 142422
\end{aligned}
$$

211.6 =

$$
\text { 7. النشاط السابع - قطرات العيون }
$$

كذلك باعتماد الأسلوب السابق نفسه ستكون كلفة الوحدة المنتجة بالثكل المعدل الشهري للإنتاج الفعلي الخاص بنشاط قطر ات العيون (298125) قنينة. 
الدكتور الشعباني و الحديدي [83]

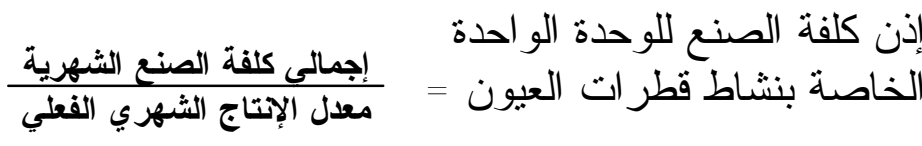

$$
\begin{aligned}
& \frac{70451660.36}{298125}= \\
& 236.31 \text { دينار /قطارة }
\end{aligned}
$$

الجاتب الثاني - كلف الأشطة الرئيسة بعد تطبيق استراتيجية تحليلات هندسة القيمة

من متطلبات تطبيق الإستر اتيجية المعينة تحديد ما يخص كل نشاط رئيس من النّاء أنشطة فرعية وكلف تلك الأنشطة ثم الحذف أو الإبقاء على وفق إنى إضافة القيمة من عدمه من قبل الأنشطة، وعليه سيتم تتاول في كل مركز إنتاجي رئيس النشاط المهم و الكبير فيه، وعليه ارتأى الباحثان أن يكون تطبيق إستر اتيجية تحلية التيلات هندسة القيمة على الأنشطة الآتية:

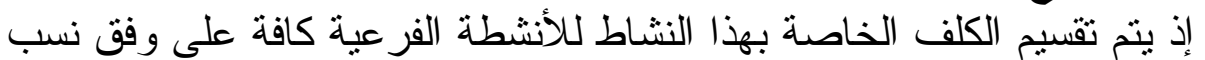

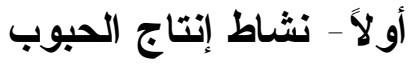

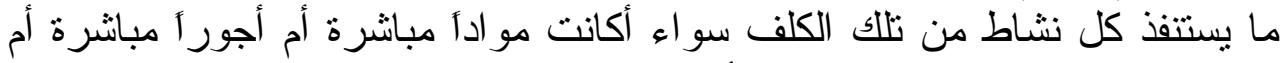
تكاليف صناعية غير مباشرة، والأنشطة الفرعية داخل هذا النشاط عددها سبعة أنها

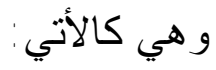

\section{أ. نشاط تهيئة المواد الأولية}

في هذا النشاط لا يوجد صرف لاولة للمواد إنما تهيئة، من هنا فإن كلفه أجور

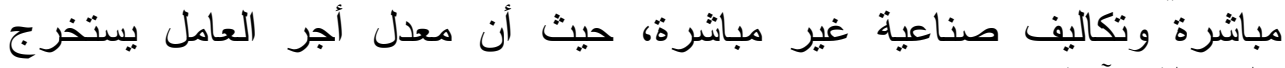

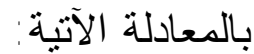

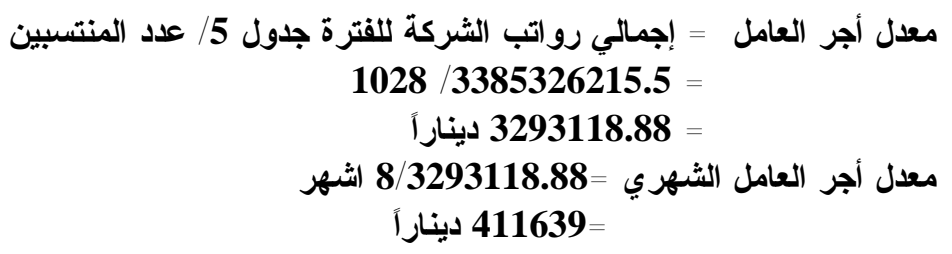

وتظهر الكلف كما في الجدول 3: 


\begin{tabular}{|c|c|c|c|c|}
\hline \multicolumn{5}{|c|}{ قائمة تكاليف لنشاط تهيئة المواد الجدول 3} \\
\hline \multicolumn{2}{|c|}{ ما يخص النشاط } & \multirow{2}{*}{ أساس التوزيع } & \multirow{2}{*}{ المبلغ المر اد } & \multirow{2}{*}{ 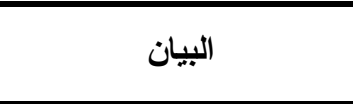 } \\
\hline كلي & جزئي & & & \\
\hline صفر & & & صفر & مو اد مباشرة: \\
\hline \multirow[t]{16}{*}{8232780} & $(20 \times 411639)$ & عدد العاملين & & أجور مباشرة \\
\hline & & & & ت.ص. \\
\hline & 34549.46 & عدد الأشطة & 241846.225 & مو اد إنشائية \\
\hline & 15733 & عدد العاملين & 157331.45 & كساوي \\
\hline & 62055 & عدد العاملين & 620551.6625 & مو اد غذائية \\
\hline & 90486.8 & عدد العاملين & 904869.41 & مو اد طبية \\
\hline & 13714.28 & عدد الأنشطة & 96000 & صبانة مباني وطرق \\
\hline & 1437.5 & عدد العاملين & 14375 & صيانة وسائط النقل \\
\hline & 982.14 & عدد الأنشطة & 6875 & صبانة أثناث و أجهزة مكاتب \\
\hline & 133096.17 & عدد العاملين & 1330961.75 & نقل العاملين \\
\hline & 48913.14 & عدد العاملين & 489131.4625 & سفر و إيفاد \\
\hline & 230.83 & عدد العاملين & 2308.3125 & مصروفات خدمية \\
\hline & 11482.2 & عدد الأنشطة & 80375.4 & اندثار مباني وطرق \\
\hline & 24723.8 & عدد العاملين & 247238.075 & اندثار وسائط النقل \\
\hline & 30512.2 & عدد الأنشطة & 213585.4125 & اندثار أنثاث \\
\hline & 98724.52 & عدد العاملين & 987245.25 & إعانات للمنتسبين \\
\hline 566641.04 & & & & إجمالي ت .ص.غ. \\
\hline 8799421.04 & & & & إجمالي كلفة النشاط \\
\hline
\end{tabular}

وقد نم اختيار أساس التوزيع الأكثر ارتباطأ، فعلى سبيل المثال يتم توزيع نقل

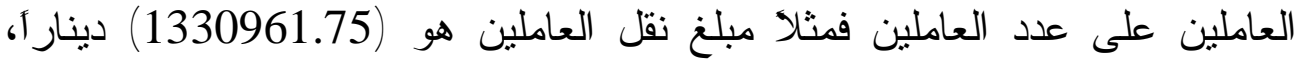

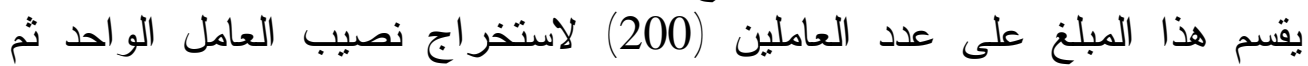

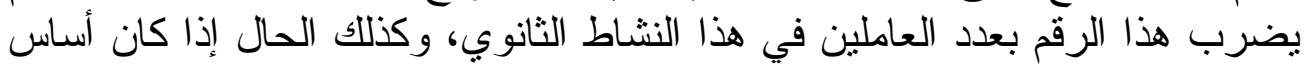

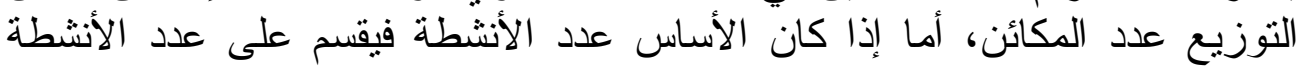

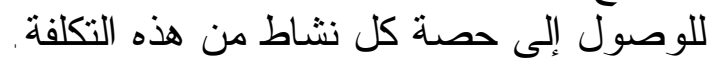


الدكتور الشعباني و الحديدي [85]

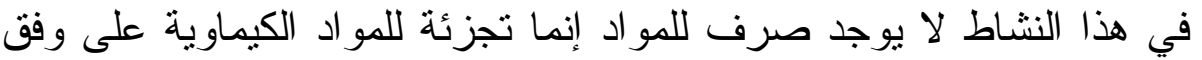
الأوزان القياسية الموجودة في سر المعرفة لكل نوع، لذلك فإن كلفه تثكون من أجور مباشرة وتكاليف صناعية غير مباشرة، وتظهر في الكلف كما في الجدول 4:

\section{الجدول 4}

قائمة تكاليف لنشاط التجزئة في إنتاج الحبوب

\begin{tabular}{|c|c|c|c|c|}
\hline \multicolumn{2}{|c|}{ ما يخص النشاط } & \multirow{2}{*}{ أساس التوزيع } & \multirow{2}{*}{ المبلغ المراد } & \multirow{2}{*}{ البيان } \\
\hline كلي & جزئي & & & \\
\hline صفر & & & صفر & مو اد مباشرة: \\
\hline 12349170 & (30X411639) & عدد العاملين & & أجور مباشرة \\
\hline & & & & ت ص. ص.غ. م: \\
\hline & 34549.46 & عدد الأنشطة & 241846.225 & مو اد إنشائية \\
\hline & 23599.71 & عدد العاملين & 157331.45 & كساوي \\
\hline & 93082.5 & عدد العاملين & 620551.6625 & مو اد غذائية \\
\hline & 135730.2 & عدد العاملين & 904869.41 & مو اد طبية \\
\hline & 13714.28 & عدد الأنشطة & 96000 & صيانة مباني وطرق \\
\hline & 2156.1 & عدد العاملين & 14375 & صيانة وسائط النقل \\
\hline & 982.14 & عدد الأنشطة & 6875 & مكاتبـبانة أثـــاث و أجهـززة \\
\hline & 199644 & عدد العاملين & 1330961.75 & نقل العاملين \\
\hline & 73369.5 & عدد العاملين & 489131.4625 & سفر و إيفاد \\
\hline & 346.2 & عدد العاملين & 2308.3125 & مصروفات خدمية أخرى \\
\hline & 11482.2 & عدد الأنشطة & 80375.4 & اندثار مباني وطرق \\
\hline & 37085.7 & عدد العاملين & 247238.075 & اندثار وسائط النقل \\
\hline & 30512.2 & عدد الأنشطة & 213585.4125 & 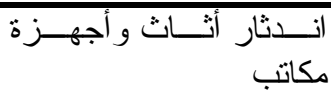 \\
\hline & 148086.6 & عدد العاملين & 987245.25 & إعانات للمنتسبين \\
\hline & 43750 & نشاطي(التجزئة & 87500 & و استشـار ات ات أبحــــــــــاث \\
\hline 848090.79 & & & & إجمالي ت ،ص.غ. م \\
\hline 13197260.79 & & & & إجمالي كلفة نشاط التجزئة \\
\hline
\end{tabular}

ج. نشاط التحضير

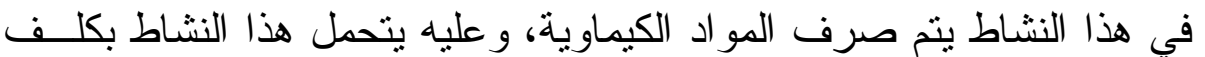

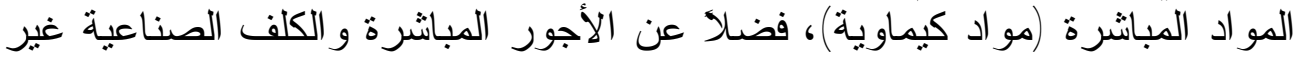

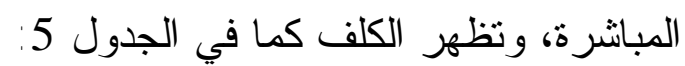




\begin{tabular}{|c|c|c|c|c|}
\hline \multicolumn{5}{|c|}{ قائمة تكاليف لتشاط التحضير في الجدول 5} \\
\hline \multicolumn{2}{|c|}{ ما يخص النشاط } & \multirow{2}{*}{ أساس التوزيع } & \multirow{2}{*}{ المبلغ المراد توزيعه } & \multirow{2}{*}{ البيان } \\
\hline كلي & جزئي & & & \\
\hline & & & & مو اد مباشرة: \\
\hline & 66807063.1125 & مخصصة بالكامل & 66807063.1125 & مو اد كيماوية \\
\hline 66807063.1125 & & & & إجمالي المو اد \\
\hline \multirow[t]{24}{*}{16465560} & (40X411639) & عدد العاملين & & أجور مباشرة \\
\hline & & & & ت.ص.ع.غ.م: \\
\hline & 300 & عدد المكائن & 750 & مو اد نفطية \\
\hline & 872863.67 & عدد المكائن & 2182159.175 & أدو ات احتياطية \\
\hline & 2802845.15 & مخصصة بالكامل & 2802845.15 & لو ازم ومهمات \\
\hline & 34549.46 & عدد الأنشطة & 241846.225 & مو اد إنشائية \\
\hline & 31466 & عدد العاملين & 157331.45 & كساوي \\
\hline & 124110 & عدد العاملين & 620551.6625 & مو اد غذائية \\
\hline & 180973.6 & عدد العاملين & 904869.41 & مو اد طبية \\
\hline & 133177.2 & مخصصية بالكامل & 133177.2 & 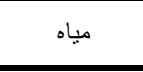 \\
\hline & 54518.74 & عدد المكائن & 136296.85 & كهرباء \\
\hline & 13714.28 & عدد الأشطة & 96000 & صيانة مباني \\
\hline & 394329.25 & عدد المكائن & 985823.125 & صيانة آلات \\
\hline & 2874.8 & عدد العاملين & 14375 & صيانة وسائط \\
\hline & 982.14 & عدد الأنشطة & 6875 & و أجهزة مكانت أثاث \\
\hline & 43750 & (التجزئة و التحضير ) & 87500 & خدمات أبحاث \\
\hline & 266192 & عدد العاملين & 1330961.75 & نقل العاملين \\
\hline & 97826 & عدد العاملين & 489131.4625 & سفر و إيفاد \\
\hline & 461.6 & عدد العاملين & 2308.3125 & خدمية أخرى مصرو \\
\hline & 11482.2 & عدد الأنشطة & 80375.4 & اندثار مباني \\
\hline & 313628.745 & عدد المكائن & 784071.8625 & اندثار آلات \\
\hline & 49447.6 & عدد العاملين & 247238.075 & اندثار وسائط \\
\hline & 30512.2 & عدد الأنشطة & 213585.4125 & و أجهزة مكاتب \\
\hline & 197448.8 & عدد العاملين & 987245.25 & إلمنتسنين \\
\hline 5657453.43 & & & & ت.ص. إجمالي \\
\hline 88930076.56 & & & & نشاط التحضير كلفة \\
\hline
\end{tabular}




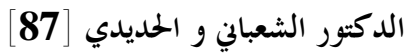

د. ن إط التعبئة

في هذا النشاط يتم صرف مو اد مباثرة (مو اد تعبئة)، من هنا فإن هذا النشاط مباط

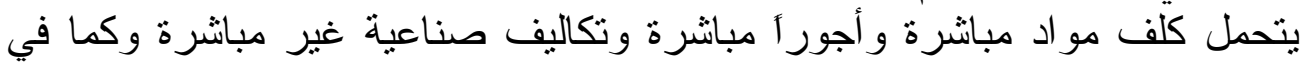
الجدول 6.

\begin{tabular}{|c|c|c|c|c|}
\hline \multicolumn{5}{|c|}{ 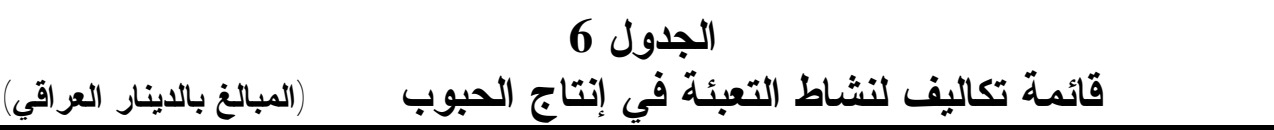 } \\
\hline \multicolumn{2}{|c|}{ ما يخص النشاط } & \multirow{2}{*}{ أنتوزيع } & \multirow{2}{*}{ المبلغ المر اد توزيعه } & \multirow{2}{*}{ البيان } \\
\hline كلي & جزئي & & & \\
\hline & & & & مو اد مباشرة: \\
\hline & 28405307.975 & مخصصة & 28405307.975 & مو اد تعبئة \\
\hline 28405307.975 & & & & إجمالي المو اد المباشرة \\
\hline \multirow[t]{21}{*}{12349170} & $(30 \times 411639)$ & عدد العاملين & & أجور مباشرة \\
\hline & & & & تص.ص. \\
\hline & 300 & عدد المكائن & 750 & مو اد نفطية \\
\hline & 872863.67 & عدد المكائن & 2182159.175 & أدو ات احتياطية \\
\hline & 34549.46 & عدد الأنشطة & 241846.225 & مو اد إنثائية \\
\hline & 23599.71 & عدد العاملين & 157331.45 & كساوي \\
\hline & 93082.5 & عدد العاملين & 620551.6625 & مو اد غذائية \\
\hline & 135730.2 & عدد العاملين & 904869.41 & مو اد طبية \\
\hline & 54518.74 & عدد المكائن & 136296.85 & كهرباء \\
\hline & 13714.28 & عدد الأنشطة & 96000 & صيانة مباني وطرق \\
\hline & 394329.25 & عدد المكائن & 985823.125 & صيانة آلات ومعدات \\
\hline & 2156.1 & عدد العاملين & 14375 & صبانة وسائط النقل \\
\hline & 982.14 & عدد الأنشطة & 6875 & صكاتب أثاث وأجهـزة \\
\hline & 199644 & عدد العاملين & 1330961.75 & نقل العاملين \\
\hline & 73369.5 & عدد العاملين & 489131.4625 & سفر و إيفاد \\
\hline & 346.2 & عدد العاملين & 2308.3125 & أخرى صـروفات خدميـــــة \\
\hline & 11482.2 & عدد الأنشطة & 80375.4 & اندثار مباني وطرق \\
\hline & 313628.745 & عدد المكائن & 784071.8625 & اندثار آلات ومعدات \\
\hline & 37085.7 & عدد العاملين & 247238.075 & اندثار وسائط النقل \\
\hline & 30512.2 & عدد الأنشطة & 213585.4125 & اككاتب أنتـاث وأجهــزة \\
\hline & 148086.6 & عدد العاملين & 987245.25 & إعانات للمنتسبين \\
\hline 2439981.19 & & & & إجمالي ت.ص.غ. م \\
\hline
\end{tabular}




\begin{tabular}{|c|c|c|c|c|}
\hline \multicolumn{2}{|c|}{ ما يخص النشاط } & \multirow{2}{*}{ ألتوزيع } & \multirow{2}{*}{ المبلغ المر اد توزيعه } & \multirow{2}{*}{ البيان } \\
\hline كلي & جزئي & & & \\
\hline 43194459.16 & & & & إجمالتي كلفة نثاط \\
\hline
\end{tabular}

في هذا النشاط يتم صرف مو اد مباشرة (مواد تغليف) لذلك ستكون الكلف لهذا النشاط كما في الجدول 7.

\begin{tabular}{|c|c|c|c|c|}
\hline \multicolumn{5}{|c|}{ 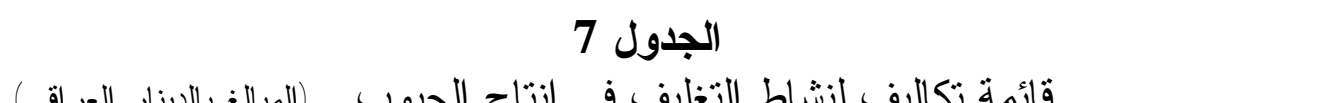 } \\
\hline \multicolumn{2}{|c|}{ ما يخص النشاط } & \multirow{2}{*}{ أساس التوزيع } & \multirow{2}{*}{ المبلغ المراد توزيعه } & \multirow{2}{*}{ البيان } \\
\hline كلي & جزئي & & & \\
\hline & & & & مو اد مباشرة: \\
\hline & 5415.4625 & مخصاملة & 5415.4625 & مو اد تغليف \\
\hline 5415.4625 & & & & إجمالي المو اد المباشرة \\
\hline \multirow[t]{19}{*}{24698340} & $(60 \times 411639)$ & عدد العاملين & & أجور مباشرة \\
\hline & & & & ت تص.غ.غ. \\
\hline & 150 & عدد المكائن & 750 & مو اد نفطية \\
\hline & 436431.8 & عدد المكائن & 2182159.175 & أدو ات احتباطية \\
\hline & 34549.46 & عدد الأنشطة & 241846.225 & مو اد إنشائية \\
\hline & 47199 & عدد العاملين & 157331.45 & كساوي \\
\hline & 186165 & عدد العاملين & 620551.6625 & مو اد غذائية \\
\hline & 271460.4 & عدد العاملين & 904869.41 & مو اد طبية \\
\hline & 27259.37 & عدد المكائن & 136296.85 & كهرباء \\
\hline & 13714.28 & عدد الأنشطة & 96000 & صيانة مباني وطرق \\
\hline & 197164.625 & عدد المكائن & 985823.125 & صيانة آلات ومعدات \\
\hline & 4312.2 & عدد العاملين & 14375 & صيانة وسائط النقل \\
\hline & 982.14 & عدد الأنشطة & 6875 & مكاتب \\
\hline & 399288 & عدد العاملين & 1330961.75 & نقل العاملين \\
\hline & 146739 & عدد العاملين & 489131.4625 & سفر و إيفاد \\
\hline & 692.4 & عدد العاملين & 2308.3125 & أخرى مسروفات خدميــــة \\
\hline & 11482.2 & عدد الأشطة & 80375.4 & اندثار مباني وطرق \\
\hline & 156814.3725 & عدد المكائن & 784071.8625 & اندثار آلات ومعدات \\
\hline & 74171.4 & عدد العاملين & 247238.075 & اندثار وسائط النقل \\
\hline
\end{tabular}


الدكتور الشعباني و الحديدي [89]

\begin{tabular}{|c|c|c|c|c|}
\hline \multicolumn{2}{|c|}{ ما يخص النشاط } & \multirow{2}{*}{ أساس التوزيع } & \multirow{2}{*}{ المبلغ المراد توزيعه } & \multirow{2}{*}{ البيان } \\
\hline كلي & جزئي & & & \\
\hline & 30512.2 & عدد الأنشطة & 213585.4125 & مكاتب انثار أنظـات و أجهــزة \\
\hline & 296173.2 & عدد العاملين & 987245.25 & إعانات للمنتسبين \\
\hline 2335261.04 & & & & إجمالي ت .ص.غ. \\
\hline 27039016.5 & & & & إجمالي كلفة نشاط \\
\hline
\end{tabular}

المصدر: من إعداد الباحثين بالاعتماد على بيانات الثركة.

و. نشاط الحزن أحن الأوني

في هذا النشاط يتم تحويل المنتج التام إلى مخزن أونام أولي داخل الورش الإنتاجية، لذلك فإن هذا النشاط يتحمل أجورَ مباشرة وتكاليف صناعية غير مباثرة

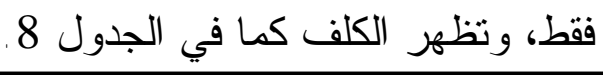

\section{الجدول 8}

قائمة تكاليف لنشاط الخزن الأولي في إنتاج الحبوب (المبالغ بالاينار العراقي)

\begin{tabular}{|c|c|c|c|c|}
\hline \multicolumn{2}{|c|}{ ما يخص النشاط } & \multirow{2}{*}{ ألتوزيع } & \multirow{2}{*}{ توبلغ المر اد } & \multirow{2}{*}{ البيان } \\
\hline كلي & جزئي & & & \\
\hline صفر & & & صفر & مو اد مباشرة: \\
\hline 4116390 & (10X411639) & عدد العاملين & & أجور مباشرة \\
\hline & & & & ت تص.غ. م: \\
\hline & 34549.46 & عدد الأنشطة & 241846.225 & مو اد إنشائية \\
\hline & 7866.5 & عدد العاملين & 157331.45 & 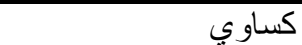 \\
\hline & 31027.5 & عدد العاملين & 620551.6625 & مواد غذائية \\
\hline & 45243.4 & عدد العاملين & 904869.41 & مو اد طبية \\
\hline & 13714.28 & عدد الأنشطة & 96000 & صبانة مباني وطرق \\
\hline & 718.7 & عدد العاملين & 14375 & صبانة وسائط النقل \\
\hline & 982.14 & عدد الأنشطة & 6875 & صكاتب أنثاث و أجهـزة \\
\hline & 66548 & عدد العاملين & 1330961.75 & نقل العاملين \\
\hline & 24456.5 & عدد العاملين & 489131.4625 & سفر و إيفاد \\
\hline & 115.4 & عدد العاملين & 2308.3125 & أخرى صـروفات خدميــــة \\
\hline & 11482.2 & عدد الأنشطة & 80375.4 & اندثار مباني وطرق \\
\hline & 12361.9 & عدد العاملين & 247238.075 & اندثار وسائط النقل \\
\hline & 30512.2 & عدد الأنشطة & 213585.4125 & انداتب أنتـاتث و أجهــزة \\
\hline & 49362.2 & عدد العاملين & 987245.25 & إعانات للمنتسبين \\
\hline 328940.38 & & & & إجمالي ت ،ص.غ. \\
\hline 4445330.38 & & & & إجمالى كلفـــة نـشـاط \\
\hline
\end{tabular}




\begin{tabular}{|c|c|c|c|c|}
\hline \multicolumn{2}{|c|}{ ما يخص النشاط } & \multirow{2}{*}{ التوزيع } & \multirow{2}{*}{ المبلغ المر اد } & \multirow{2}{*}{ البيان } \\
\hline كلي & جزئي & & & \\
\hline & & & & الخزن الأولي \\
\hline
\end{tabular}

\section{ز. نشاط خزن الإتتاج التام داخل القسم}

في هذا النشاط يتم خزن الإنتاج التام في مخزن داخد داخل القسم، لكي يحوّل فيما

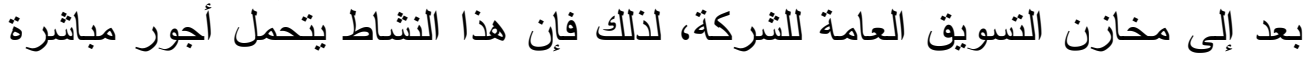
وتكاليف صناعية غير مباشرة فقط وتظهر الكلف كما في الجدول 9.

\section{الجدول}

قائمة تكاليف لنشاط خزن الإنتاج التام في إنتاج الحبوب (المبالغ بالدينار العراقي)

\begin{tabular}{|c|c|c|c|c|}
\hline \multicolumn{2}{|c|}{ ما يخص النشاط } & \multirow{2}{*}{ أساس التوزيع } & \multirow{2}{*}{ المبلغ المر اد توزيعه } & \multirow{2}{*}{ البيان } \\
\hline كلي & جزئي & & & \\
\hline صفر & & & صفر & مو اد مباشرة: \\
\hline 4116390 & $(10 X 411639)$ & عدد العاملين & & أجور مباشرة \\
\hline & & & & ت .ص.غ. \\
\hline & 34549.46 & عدد الأنشطة & 241846.225 & مو اد إنشائية \\
\hline & 7866.5 & عدد العاملين & 157331.45 & كساوي \\
\hline & 31027.5 & عدد العاملين & 620551.6625 & مو اد غذائية \\
\hline & 45243.4 & عدد العاملين & 904869.41 & مو اد طبية \\
\hline & 13714.28 & عدد الأنشطة & 96000 & صبانة مباني وطرق \\
\hline & 718.7 & عدد العاملين & 14375 & صيانة وسائط النقل \\
\hline & 982.14 & عدد الأنشطة & 6875 & صكاتب يـانة أنثـات و أجهــزة \\
\hline & 66548 & عدد العاملين & 1330961.75 & نقل العاملين \\
\hline & 24456.5 & عدد العاملين & 489131.4625 & سفر و إيفاد \\
\hline & 115.4 & عدد العاملين & 2308.3125 & مصروفات خدمية أخرى \\
\hline & 11482.2 & عدد الأنشطة & 80375.4 & اندثار مباني وطرق \\
\hline & 12361.9 & عدد العاملين & 247238.075 & اندثار وسائط النقل \\
\hline & 30512.2 & عدد الأنشطة & 213585.4125 & انــــثار أثتــاتث و أجهــزة \\
\hline & 49362.2 & عدد العاملين & 987245.25 & إعانات للمنتسبين \\
\hline 328940.38 & & & & إجمالي ت .ص.غ. \\
\hline 4445330.38 & & & & الإنتاج التام كلفة نشاط خــزن \\
\hline
\end{tabular}

تحليلات هندسة القيمة لنشاط إنتاج الحبوب

بعد التعرف على كلفة الأنشطة الثانوية داخل نشاط إنداط إنتاج الحبوب بالامكان

رسم سلسلة القيمة للنشاط كما في الثكل 2. 


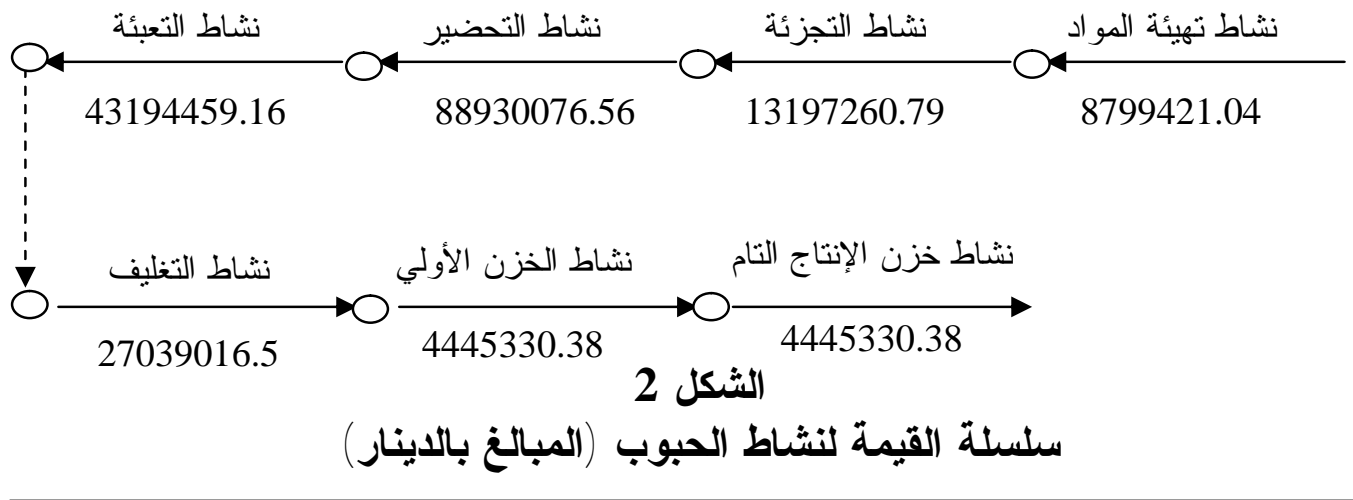

يلاحظ من الثكل السابق أن إجمالي كلفة الصنع هي (190050894.81)

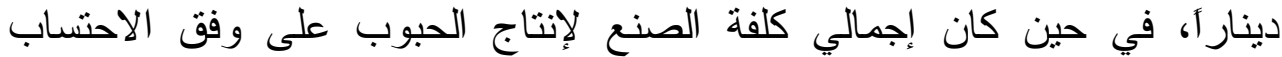

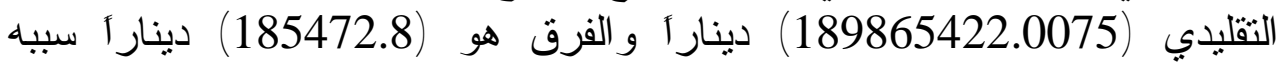
وجود أجرة عامل مشترك بين نشاطي (الحبوب والكبسول)، لذا فإن كل نشان لناط

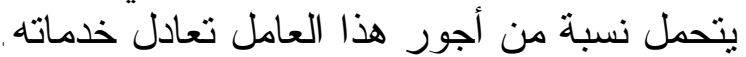

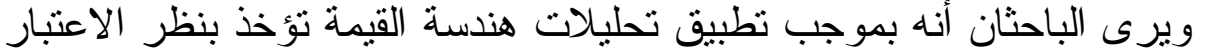

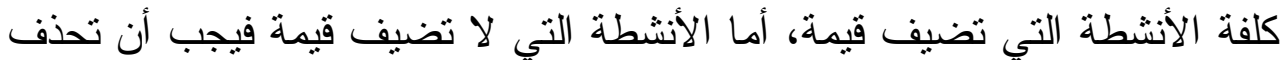

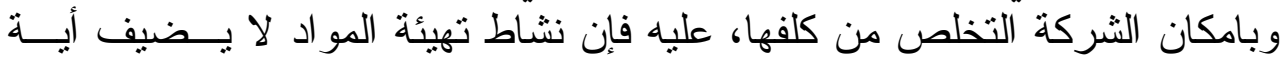

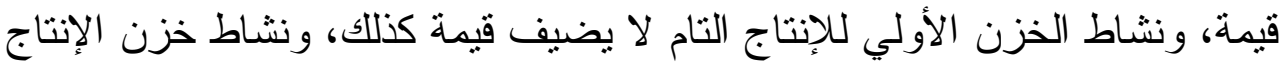

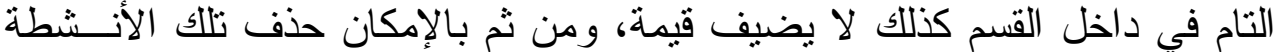
و التخلص من كلفها فتصبح كلفة إنتاج الحبوب على ونى وفق الآتي:

\begin{tabular}{|c|c|}
\hline كلقته & اسم النشاط \\
\hline 13197260.79 & نشاط التجزئة \\
\hline 88930076.56 & نشاط التحضير \\
\hline 43194459.16 & نشاط التعبئة \\
\hline 27039016.5 & نشاط التغليف \\
\hline 172360813 & إجمالي كلفة إنتاج الحبوب \\
\hline
\end{tabular}

ومن خلال المقارنة بين كلف إنتاج الحبوب قبل وبعد تطبيق تحليلات هندسة القيمة تكون النتيجة من حيث التخفيض كالأتي:

\begin{tabular}{|c|c|c|c|}
\hline مقدار التخفيض & بعد التطبيق & قبل التطبيق & البيان \\
\hline 17504609 17ينار & 172360813 & 189865422 & كلفة الإنتاج الثهري \\
\hline 210055308 2دينار & 2068329756 & 2278385064 & مقدار التخفيض السنوي \\
\hline 0.82 & 6.5 & 7.32 & كلفة الوحدة المنتجة \\
\hline
\end{tabular}


ثناتياً - نشاط إنتاج المراهم و الكريمات

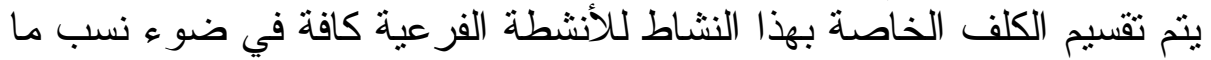

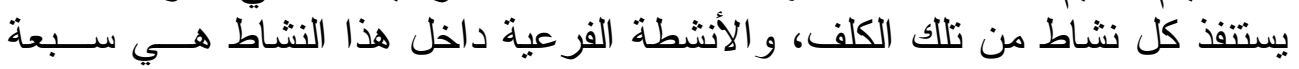

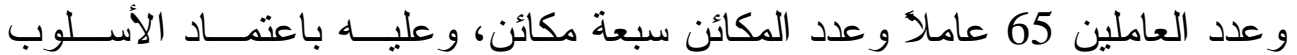
المعتمد نفسه في خط الحبوب سيكون رسم سلسلة القيمة للنشاط كما في الثكل 3.

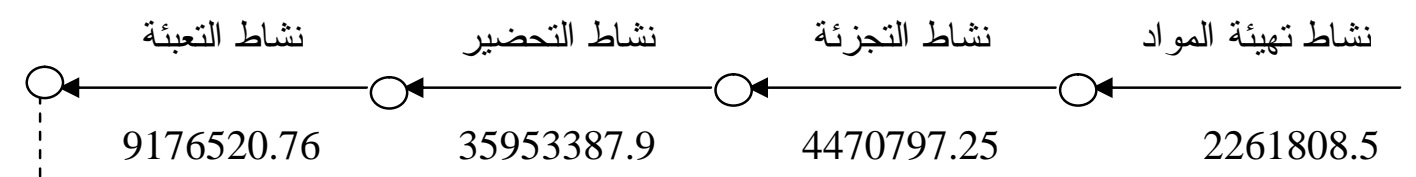

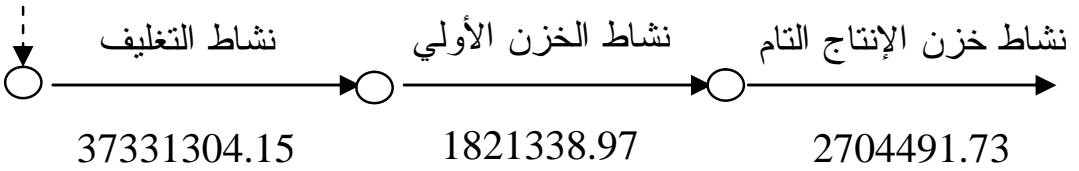

الشكل

سلسلة القيمة لنشاط إنتاج المراهم و الكريمات (المبالغ بالدينار)

المصدر : من إعداد الباحثين.

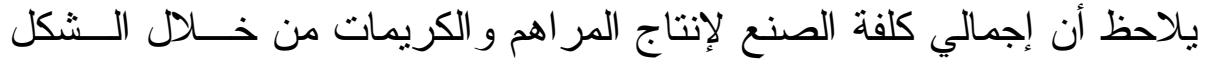

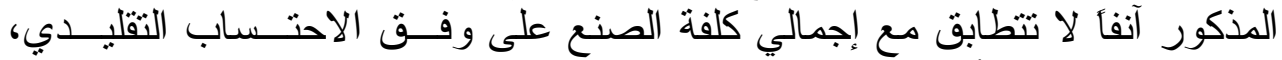

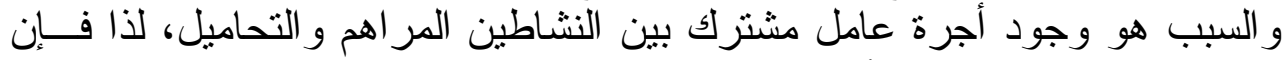
كل نشاط يتحمل نسبة من أجرة ذلاب الك العامل.

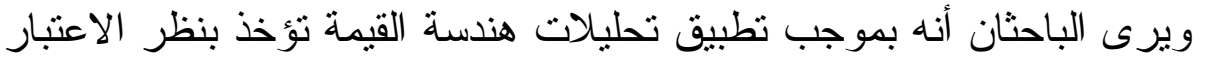

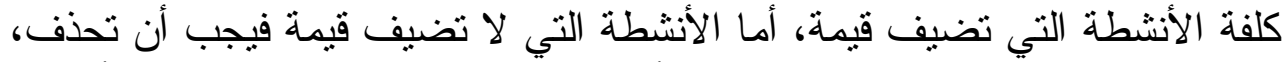

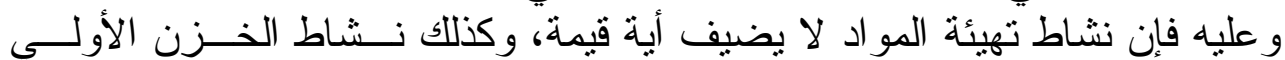

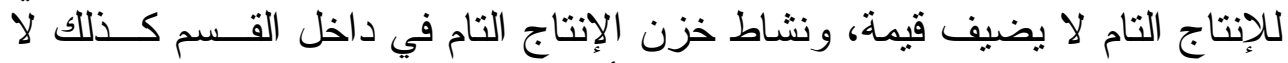

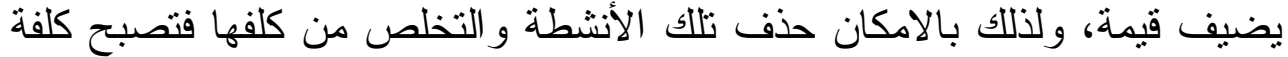
إنتاج المر اهم و الكريمات على ولالان الآتي: 


\begin{tabular}{|c|c|}
\hline كلقته & اسم النشاط \\
\hline 4470797.25 & نشاط التجزئة \\
\hline 35953387.9 & نشاط التحضير \\
\hline 9176520.76 & نشاط التعبئة \\
\hline 37331304.15 & نشاط التغليف \\
\hline 86932010.06 & إجمالي كلفة نشاط إنتاج المر اهم و الكريمات \\
\hline
\end{tabular}

ومن خلال المقارنة بين كلف إنتاج المر اهم و الكريمات قبل تطبيق تحلــيلات هندسة القيمة وبعده تكون النتيجة من حيث التخفيض كار بالثكل الآتي :

\begin{tabular}{|c|c|c|c|}
\hline مقدار التخفيض & بعد التطبيق & قبل التطبيق & البيان \\
\hline & 86932010.06 & 94027583.95 & كلفة الإنتاج الشهري \\
\hline 85146886.6دينار & 1043184120.7 & 1128331007.4 & مقدار التخفيض السنوي \\
\hline 16.68دينار & 204.82 & 221.5 & كلفة الوحدة المنتجة \\
\hline
\end{tabular}

ثالثاً - نشاط إنتاج الاشربة

وبالأسلوب نفسه سيكون رسم سلسلة القيمة لنشاط الاشربة كما في الثكل 4:

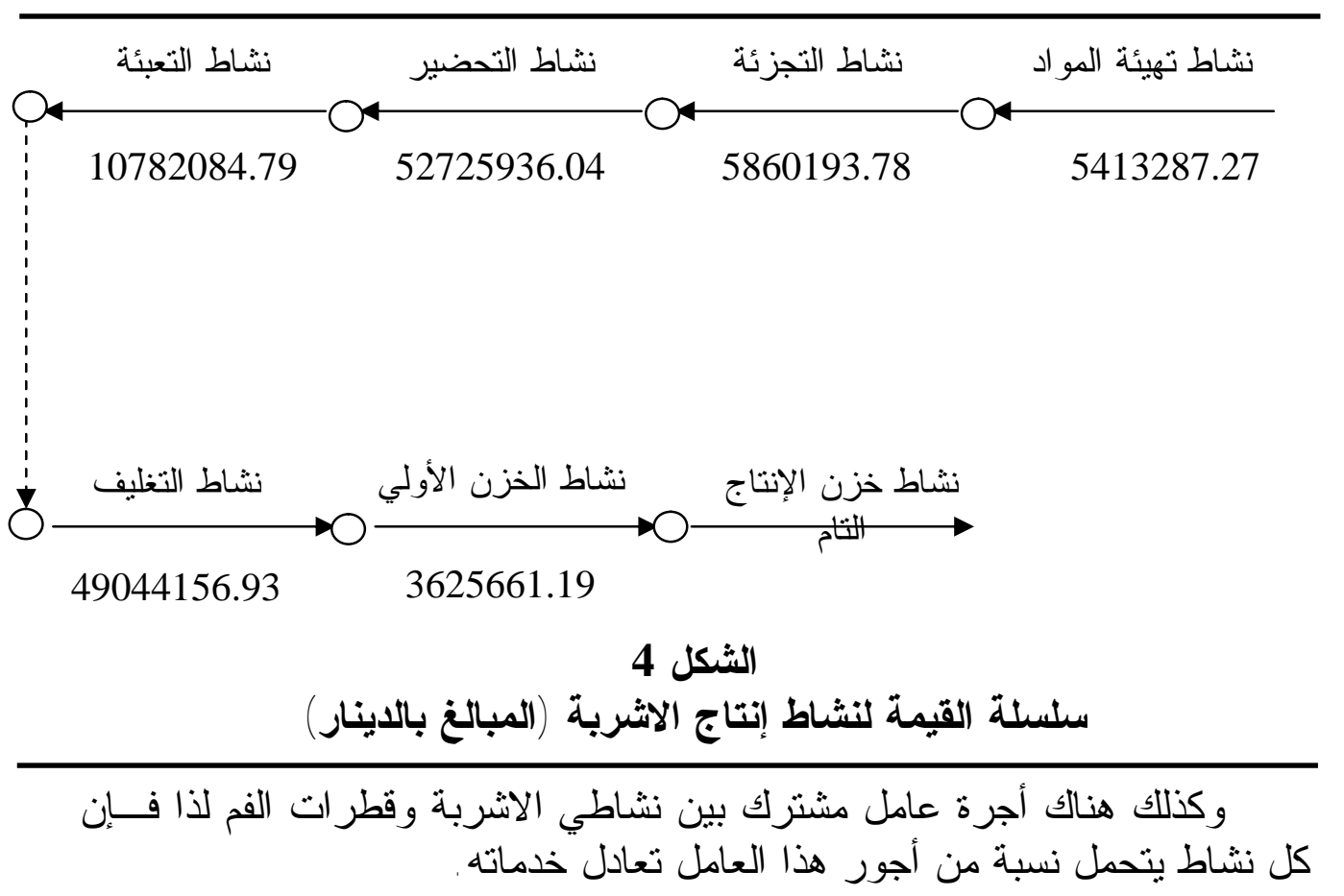




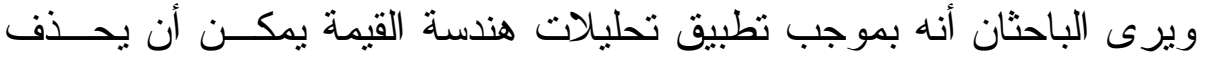

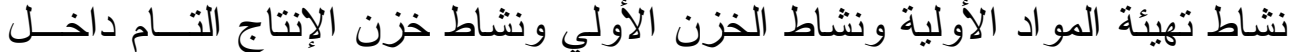

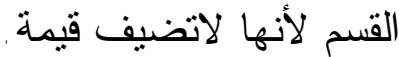
و وليه فإن الأنشطة التي تضيف قيمة هي التي تمثل كلفة التـصنيع الجديــدة

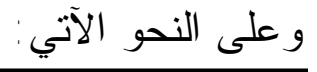

\begin{tabular}{|c|c|}
\hline كلقته & اسم النشاط \\
\hline 5860193.78 & نشاط التجزئة \\
\hline 52725936.04 & نشاط التحضير \\
\hline 10782084.79 & نشاط التعبئة \\
\hline 49044156.93 & نشاط التغليف \\
\hline 118412371.5 & إجمالي كلفة نشاط إنتاج الاثربة \\
\hline
\end{tabular}

ومن خلال المقارنة بين كلف إنتاج الاشربة قبل تطبيق تحليلات هندسة القيمة وبعده تكون النتيجة من حيث التخفيض بالثنكل الآتي:

\begin{tabular}{|c|c|c|c|}
\hline مقار التخفيض & بعد التطبيق & قبل التطبيق & البيان \\
\hline 14586420 & 118412371.5 & 132998791.5 & كلفة الإنتاج الثهري \\
\hline 175037040 & 1420948458 & 1595985498 & مقدار التخفيض السنوي \\
\hline 31.18 & 253.07 & 284.25 & كلفة الوحدة المنتجة \\
\hline
\end{tabular}

رابعاً - نثاط إنتاج قطر ات العيون

وكذا الحال سيكون التخفيض في كلف إنتاج القطر ات بعد تطبيق سلسلة القيمة

$$
\text { كما في الجدول } 6 .
$$

\begin{tabular}{|c|c|c|c|c|c|}
\hline \multicolumn{6}{|c|}{ الجدول 6} \\
\hline \multicolumn{2}{|c|}{ مقار التخفيض } & بعد التطبيق & قبل التطبيق & & 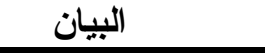 \\
\hline \multicolumn{2}{|c|}{11327944.99} & 59123715.37 & 70451660.36 & \multicolumn{2}{|c|}{ كلفة الإنتاج الثهري } \\
\hline \multicolumn{2}{|c|}{135935339.88} & 709484584.44 & 845419924.32 & \multicolumn{2}{|c|}{ مقدار التخفيض السنوي } \\
\hline \multicolumn{2}{|l|}{38} & 198.31 & 236.31 & \multicolumn{2}{|c|}{ كلفة الوحدة المنتجة } \\
\hline \multicolumn{6}{|c|}{ لآتي: فإن ملخص مقدار التخفيض و الذي يخص الأنشطة محل التطبيق كان على } \\
\hline نسبة التخفيض & & مقار التخفيض السنَ & ر التخفيض الشهري & & النشاط \\
\hline$\% 11$ & & 210055308 & 17504609 & & الحبوب - ل الحب \\
\hline
\end{tabular}


الدكتور الشعباني و الحديدي [95]

\begin{tabular}{|c|c|c|c|}
\hline$\% 7.5$ & 85146886.6 & 7095573.89 & المر اهم و الكريمات \\
\hline$\% 11$ & 175037040 & 14586420 & الاشربة \\
\hline$\% 16$ & 135935339.88 & 11327944.99 & قطر ات العيون \\
\hline$\cdots$ & 606174574.5 & 50514547.88 & إجمالي التخفيض \\
\hline
\end{tabular}

مع ملاحظة أنه لم يتم أخذ الأنشطة كافة للتقيد بمحدودية صفحات البحث ولو الأن أخذت الأنشطة كافة لأمكن عرض مقدار التخفيض السنوي في إجنا الجمالي كلف الإنتاج

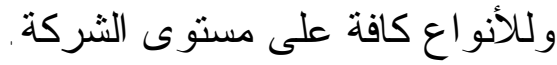

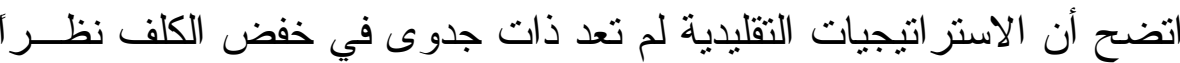

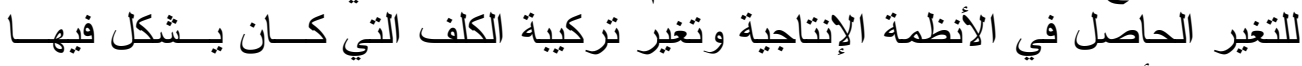

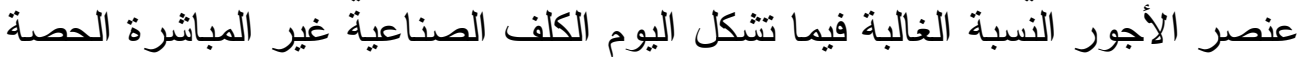

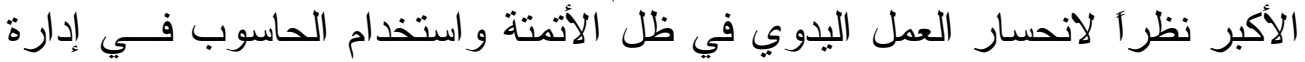

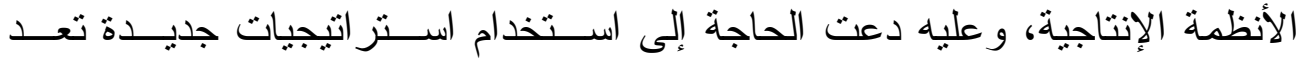

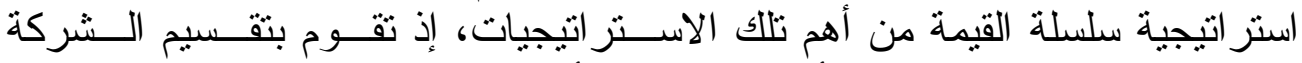

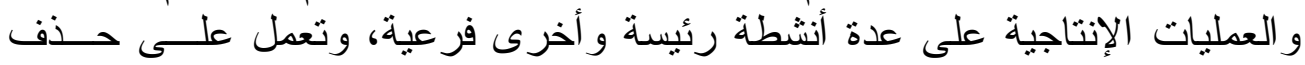

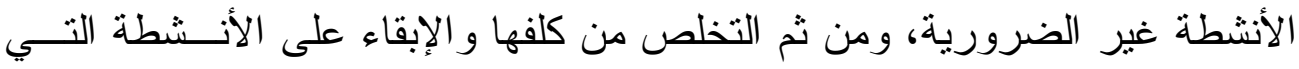

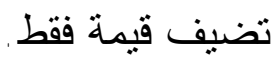
وقد تبين من خلال تطبيق هذه الاستر اتيجية على الصناعات العر اقية وبالذات

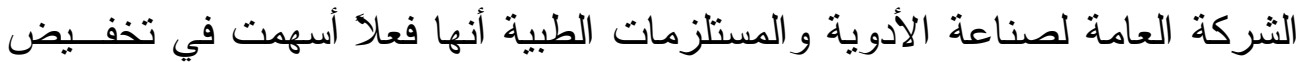
كلف الإنتاج من خلال التخلص من الأنشطة غير الضرورية وحذفها والهاء الأستغناء عن كلفها.

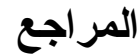

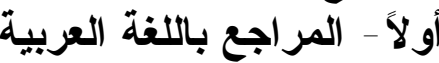

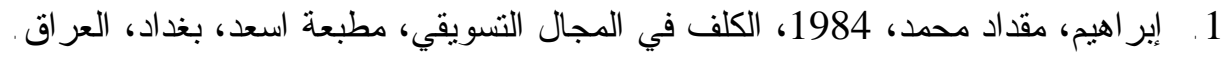

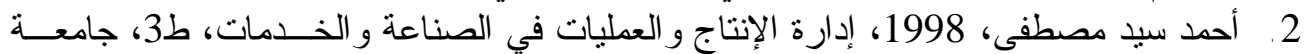

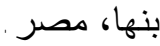

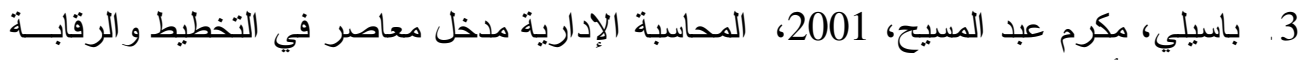

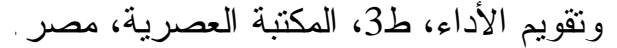

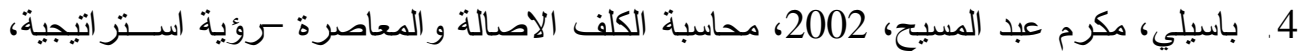

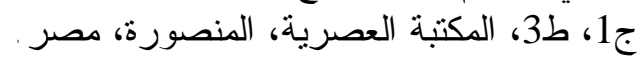

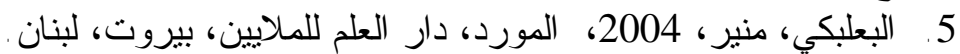

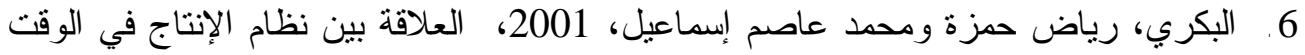

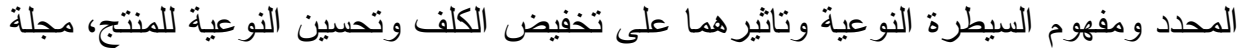
العلوم الاقتصادية و الإدارية، المجلد 8، العدد 28، كلية الإدارة و الاقتصاد، جالئ جامعة بغداد . 
7. البكري، رياض حمزة، 1992، التخفيض الوهمي و التخفيض الحقبقي للتكاليف، مجلة الإدارة

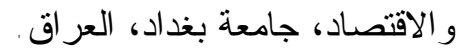

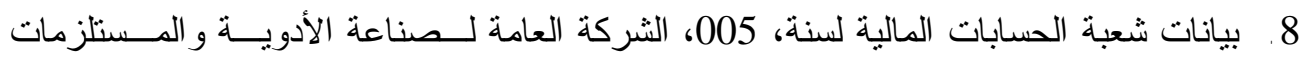

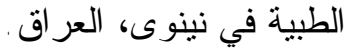

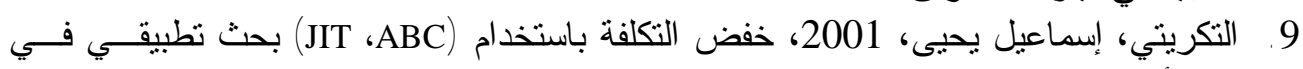
المنشأة العامة للصناعات الصوفية معمل 30 تموز، مجلة العلوم الاقتصسادية و الإدارية، العدد

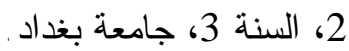
10. جبر ، نبيه وخالد عبد العزيز، 1999، تخفيض الكلف المجالات و الأساليب، مجلــة البحــوث

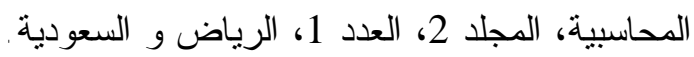

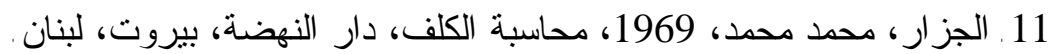

12. جمعة، احمد حلمي، عطا اله خليل و خالد إبر اهيم الطراونة، 1999، دحاسبة الكلف المتقدمة، لئه

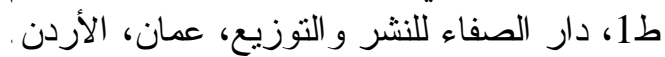

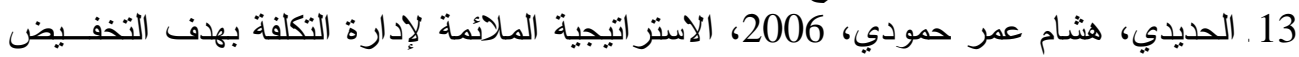

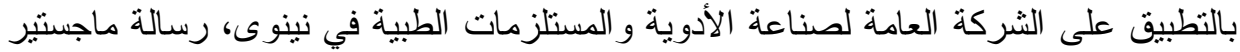

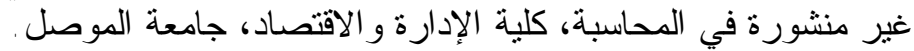

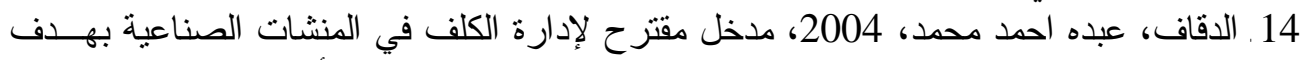

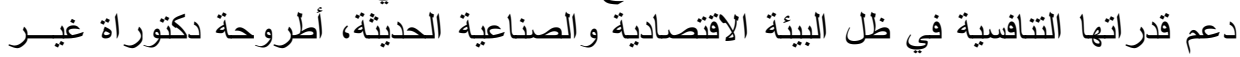

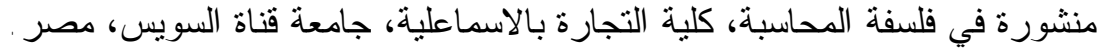

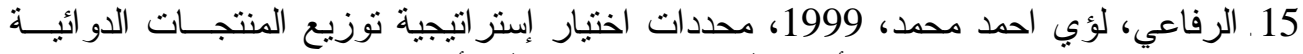

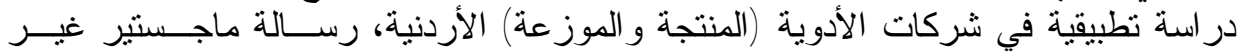

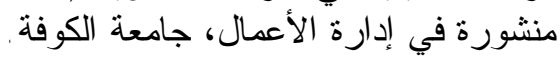

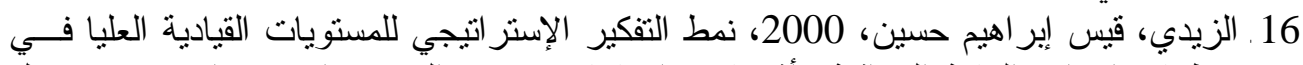

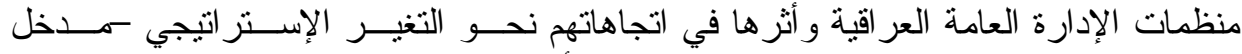

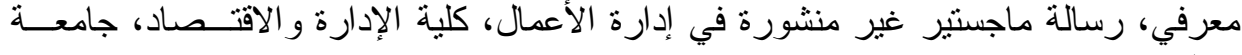

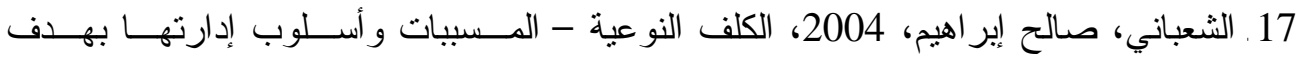

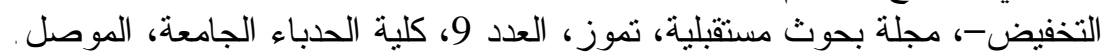

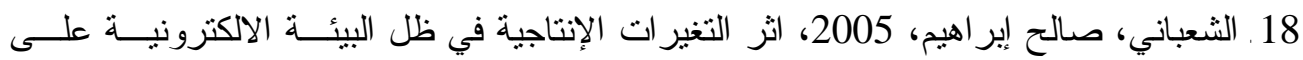

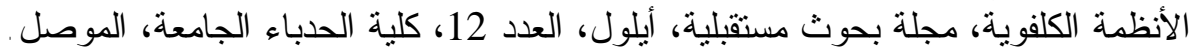

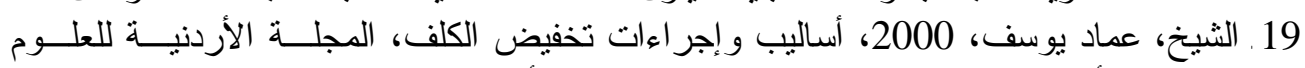

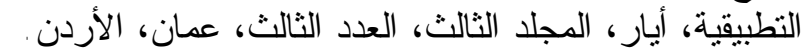

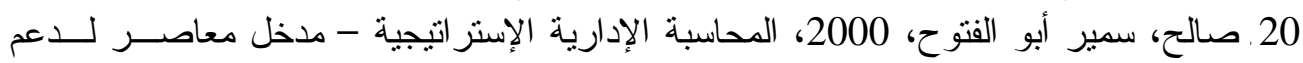

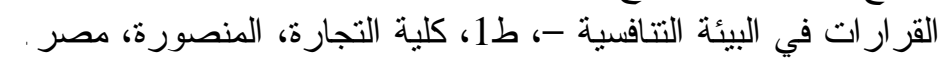

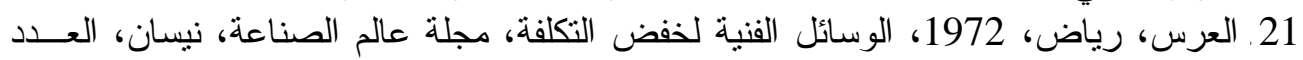

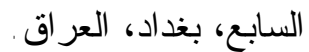

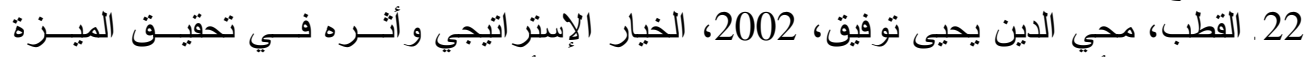

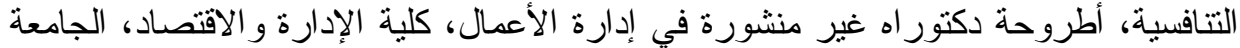




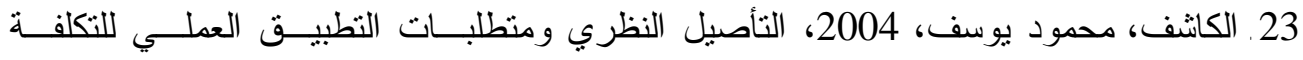

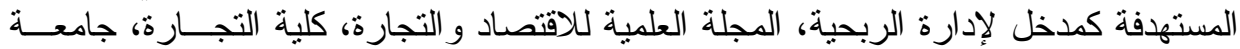

المنصورة.

24. الكسب، علي إير اهيم حسين، 2004، المعلومات المحاسبية اللازمة لاعتماد أسلوب التحسـسين

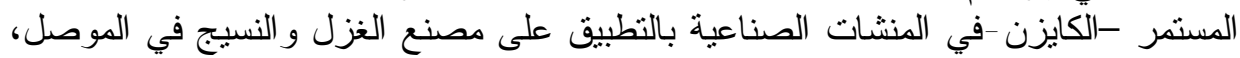

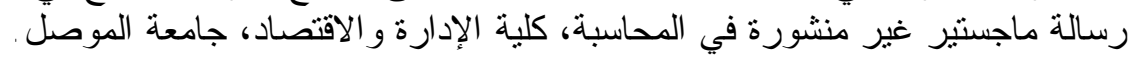

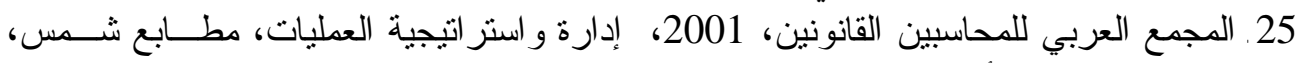

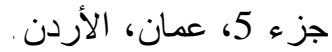

26. المخلافي، نجيب طاهر عبدا، 2002، استخدام نظام ABC في قياس تكاليف أنشطة المصارف

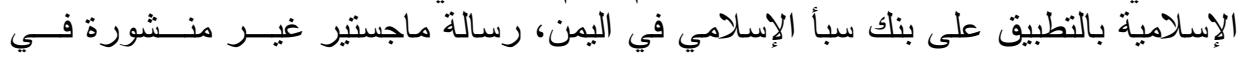

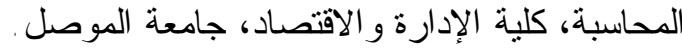

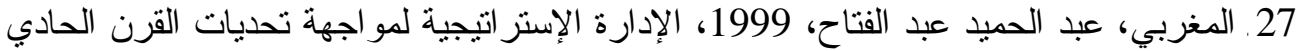

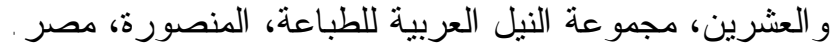

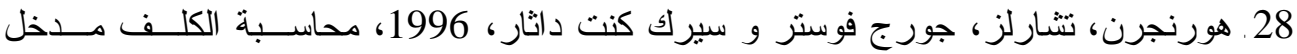

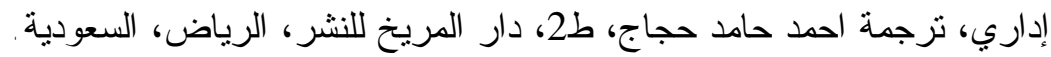

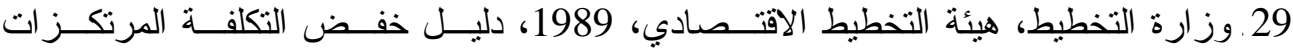

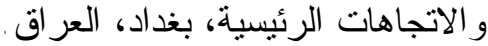

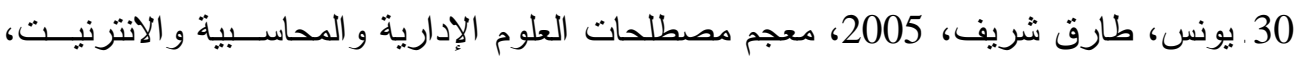

ط1، دار و ائل للنشر ، عمان، الأردن .

\section{ثانياً - المراجع باللغة الأجنبية}

1. Blocher, Edward, Chem, hing and Hin, Thomas, 1999, Cost Management: A strategic Emphasis, $1^{\text {st }}$ Ed, McGraw-Hill Co,USA.

2. Drury, Colin, 2000, Management and Cost Accounting, $5^{\text {th }}$ ed, Business Press, Thomson Learning.

3. Johanson, Gerry and Scholes, Kevan,1993,Expbring Corporate Strategy: TEXT and Cases, $3^{\text {rd }}$ ed., Prentice-Hall, New York,

4. Morse, Wayne, J \& Davis, James, R \& Hartgraves, 2003, AL- Management Accounting a Strategic Approach, 3rd, ed- Copyright by South Western -USA-.

5. Schroeder, Roger, G-Operations Management, Decision Making in the Operation Function, $2^{\text {nd }}$ ed-McGraw, Hillbook Company- Singapore-. 
ص ص [181-157]

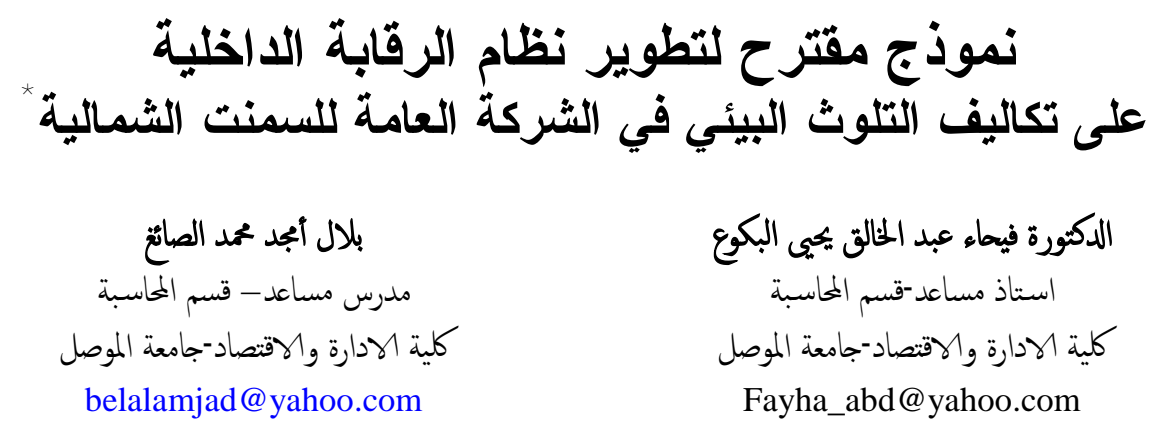

\section{المستخلص}

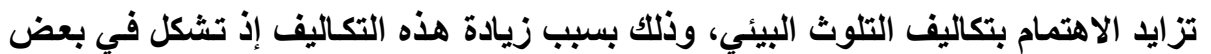

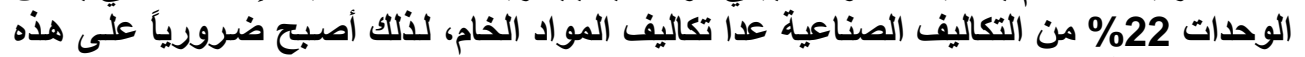

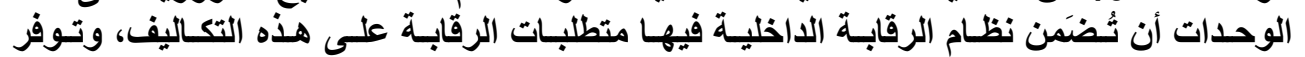

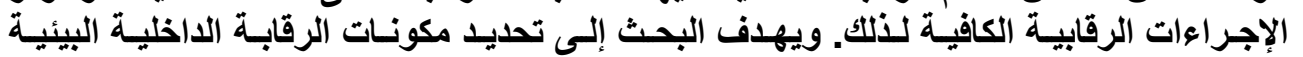

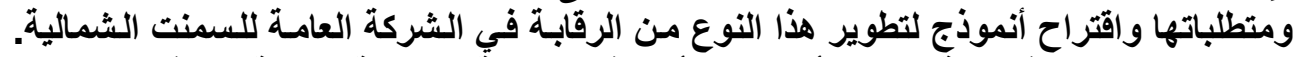

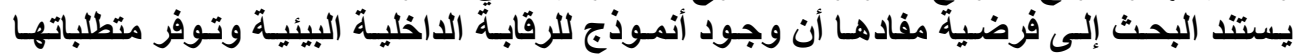

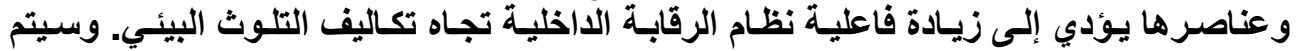

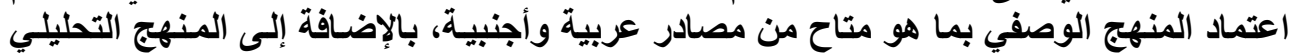

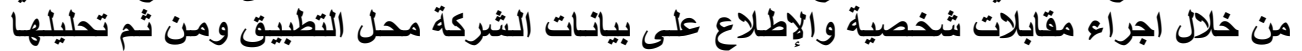

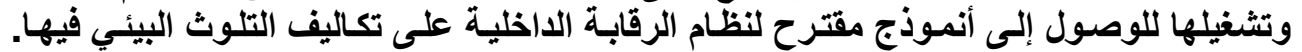

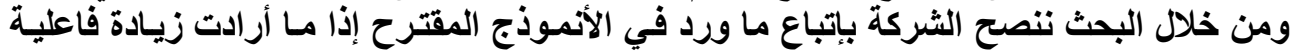

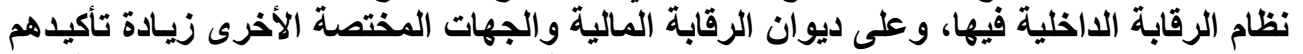

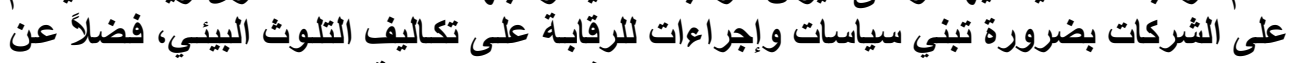

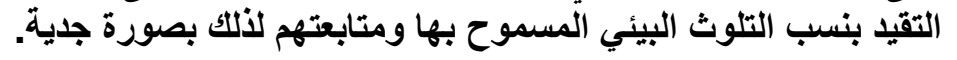

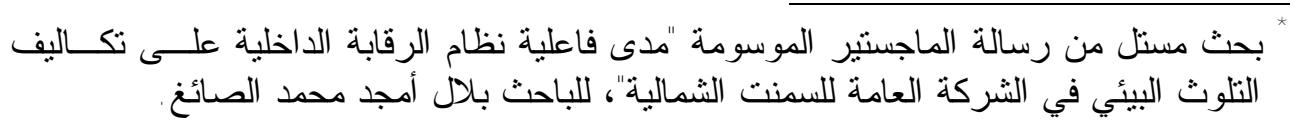


الدكتورة البكوع و الصائغ [158]

\title{
Suggested Model of Developing an Internal Control System on Environmental Pollution Costs in the Northern Cement General Company
}

\author{
Fayhaa A. Kh. Al-Bakkoa (PhD) \\ Assistant Professor \\ University of Mosul
}

\author{
Bilal A. Al-Saegh \\ Assistant Lecturer \\ University of Mosul
}

\begin{abstract}
The interest in environmental pollution has been magnificently increased for the increase in costs. Some units may constitute $22 \%$ of industrial costs except the raw materials. Therefore, units should be warranted an internal control system that is met by the cost control requirements and provide the sufficient control procedures. The current research also aims to specify the components of environmental internal control and the requirements and suggesting a model to develop this sort of control in the State Company of Northern Cement. It is hypothesized that the environmental internal control model and the provision of requirements may lead to the increase in the system of internal control towards the costs of the environmental pollution. The descriptive approach has been depended as for Arabic and foreign references. In addition to the analytical approach, the interviews and data of the company have been taken into consideration to reach to a suitable suggested model to the system of internal control to the costs of environmental pollution. It recommended that the company should follow the suggested model to increase the efficacy of internal control and the financial control has to ensure the policy and procedures of environmental control costs, as well as assisting the rates of allowed environmental pollution.
\end{abstract}

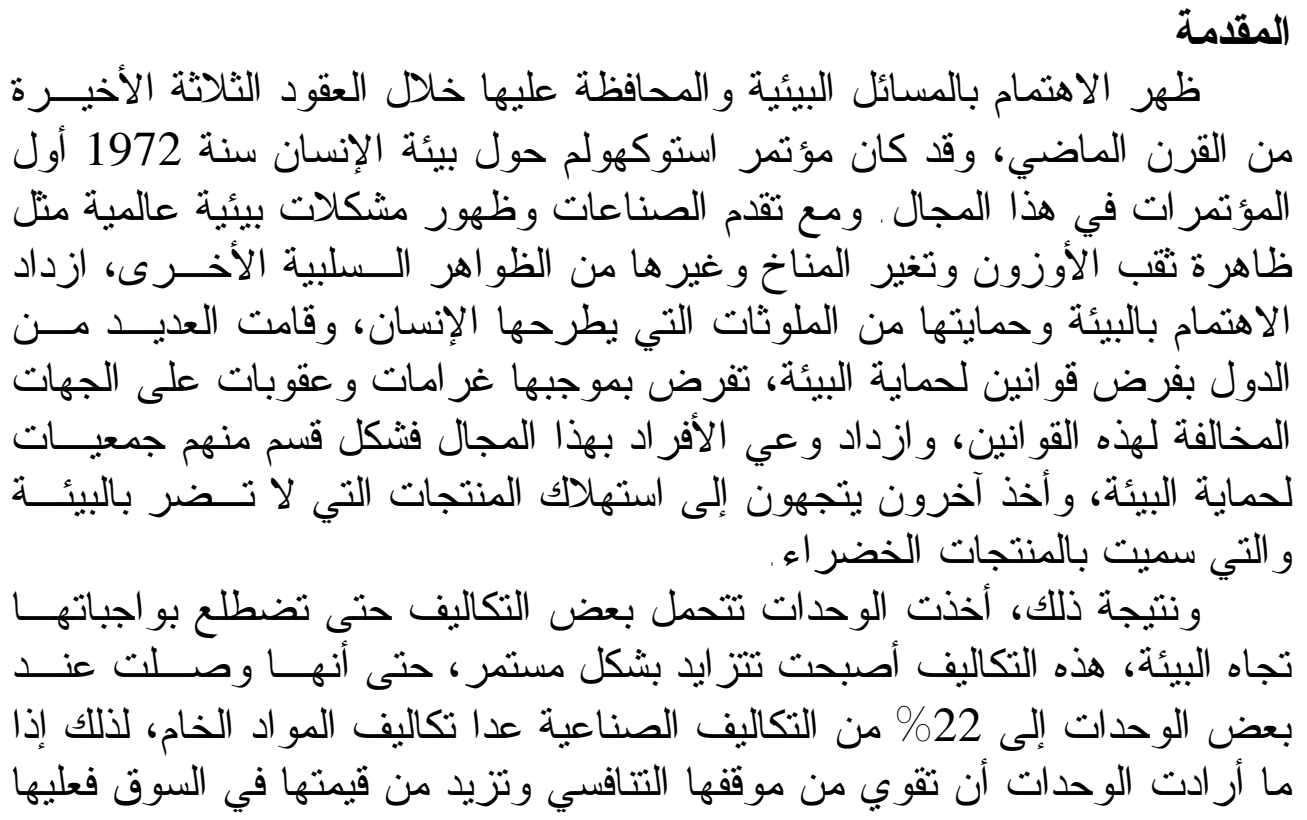




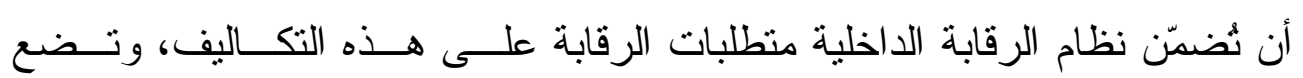
الإجر اءات الرقابية الكفيلة بتحقيق الفاعلية على هذه التكاليف.

مشكلة البحث الرثان

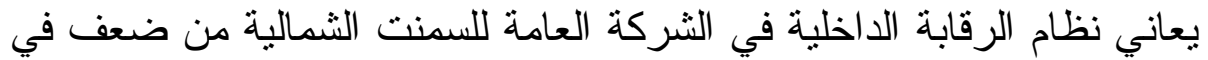

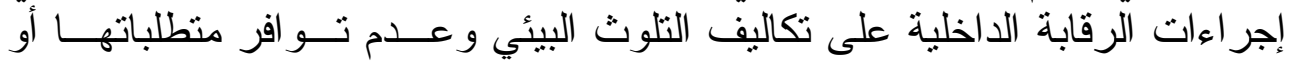
مكوناتها، مما يحول دون تطبيق رقابة داخلية فاعلة على تكاليف التلوث البيئي.

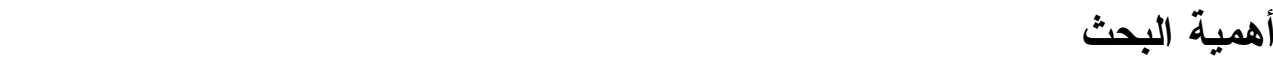

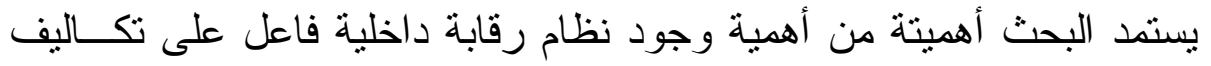

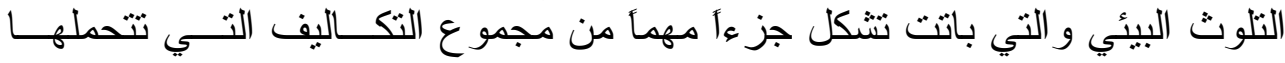

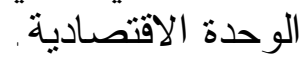

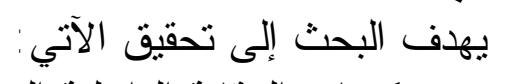

هدف البحث

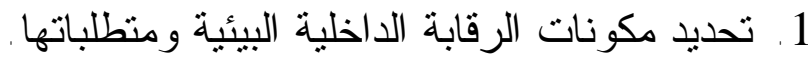

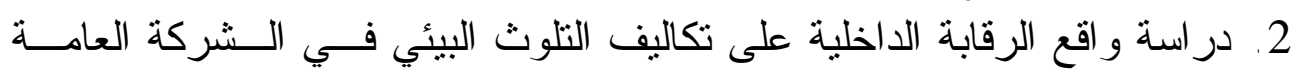
اللسمنت الثمالية.

3. اقتز اح أنموذج لتطوير نظام الرقابة الداخلية على تكاليف التلوث البيئسي فـي الثركة العامة للسمنت الثمالية.

$$
\text { بستتد البحث إلى الفرضية الآتية: }
$$

\section{فرضية البحث}

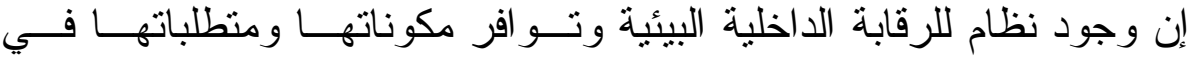

الوحدات يؤدي إلى زيادة فاعلية نظام الرقابة الداخلية تجاه تكاليف التلوث البئية البئي في

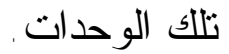

\section{سيتم اعتماد المنهجين الآتيين لتحقيق أهداف البحث:}

\section{منهجية البحث}

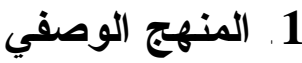

وذللك من خلاّل الاستعانة بما هو متاح من مر اجع عربية وأجنبية لها علاقــة بمجال البحث.

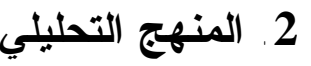

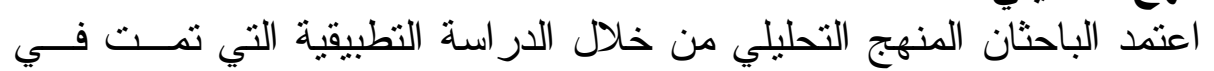

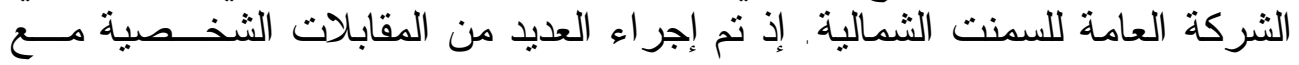
منتسبي الثركة و على مختلف اختصاصاتهم، ثم قام الباحثان بعد ذللك بتحليلها كـي التي 


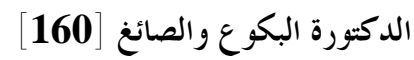

يتم الوصول إلى تقييم دقيق لنظام الرقابة الداخلية على تكاليف التلوث البيئي فـي الثركة العامة للسمنت الثمالية.

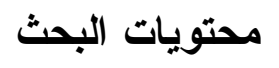

- طبيعة نظام الرقابة الداخلية على تكاليف النلوث البيئي.

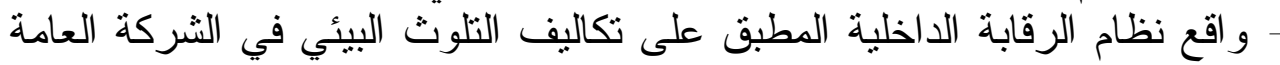
ل اللسمنت الثمالية.

- نطوير نظام الرقابة الداخلية على تكاليف التلوث البيئي فــي الــشركة العامــة

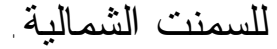

\section{طبيعة نظام الرقابة الاخلية على تكاليف التلوث البيئي}

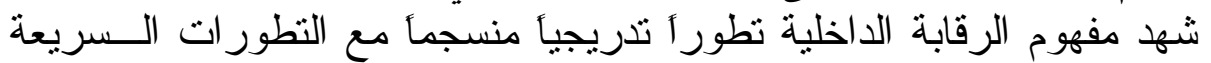

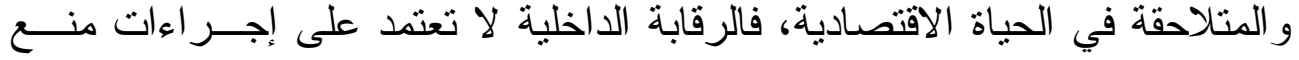

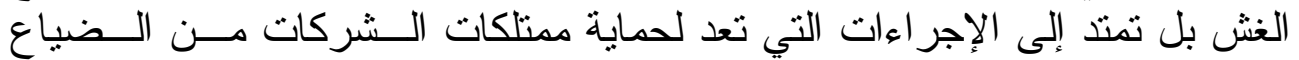

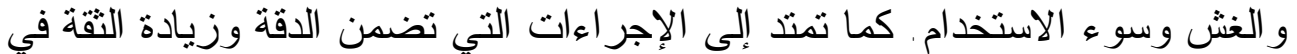

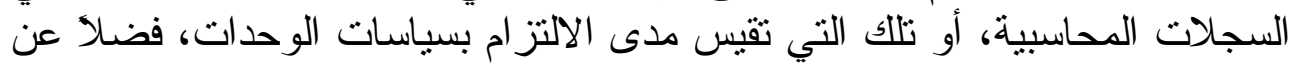
الإجر اءات اللازمة لتقويم كفاءة عملياتها (البيومي، 1992 1992، 5). 1 -1 1 تعريف نظام الرقابة الأخلية

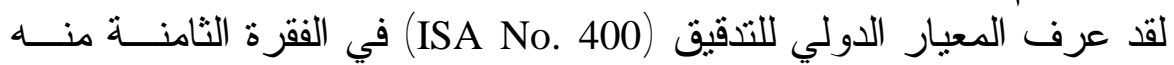

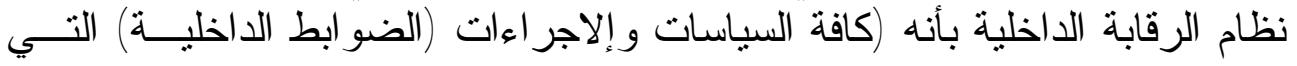

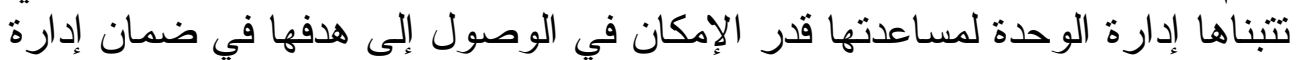

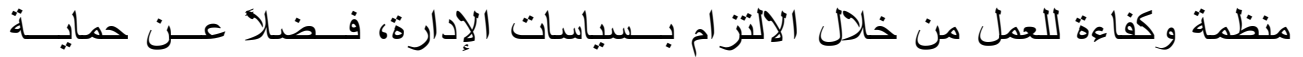

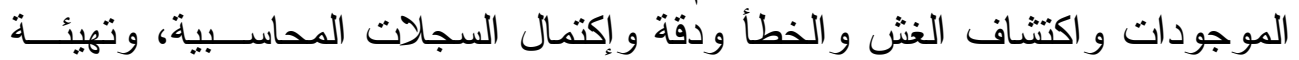

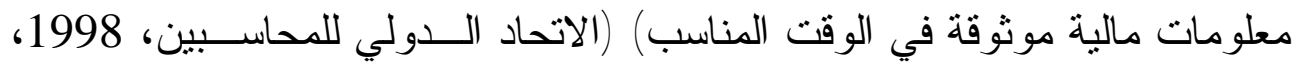

كذلك عرفت لجنة COSO المنبيقة عن لجنة Treadway نظام الرقابة الداخلية

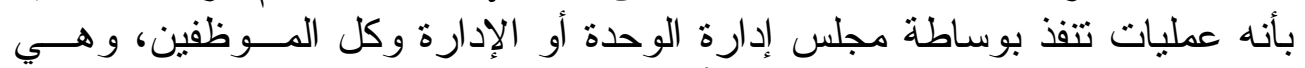
(Whitlington \& Pany, 1998, تصمح لتوفير ضمان معقول لتحقيق الأهداف الآنية الآنية

$$
\text { - - - الاعتماد على القو ائم المالية. }
$$

- كفاءة العمليات وفاعليتها. - - الالتز ام بتطبيق القو انين و النتريعات.

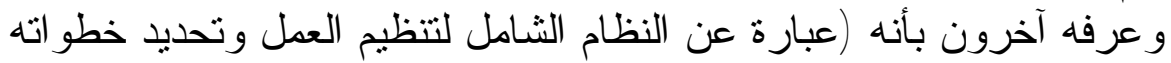

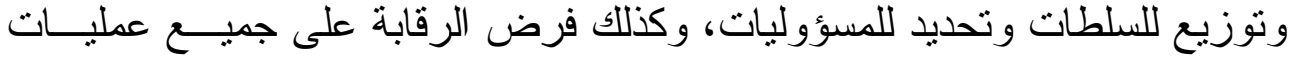
الوحدة) (أمين، 2001، 3نطئ ). 
ومن هذه التعاريف السابقة يمكن استخلاص الأهداف الرئيسة لنظام الرقابــة

$$
\text { الداخلية ومن أهم هذه الأهداف الآتي: الآنيك: }
$$

1. دث العاملين على الالتز ام بسياسات الإدارة وخططها.

2. 3. توفير حماية للموجودات.

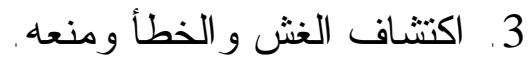

4. نوفير الدقة اللازمة في البيانات المحاسبية.

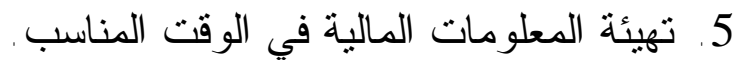

6. تنظيم العمل وتحديد خطو اته، وتوزيع للسلطات وتحات العديد للمسؤوليات.

7.

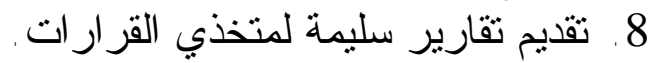

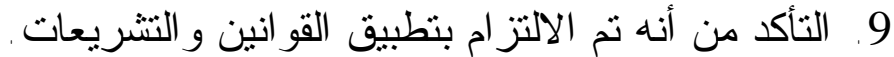

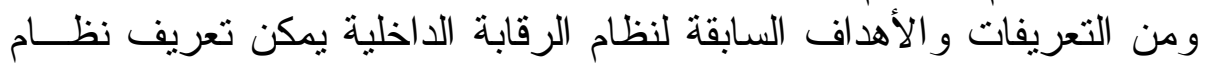

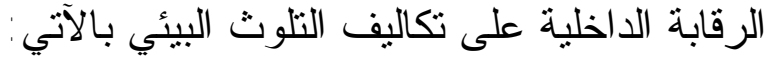

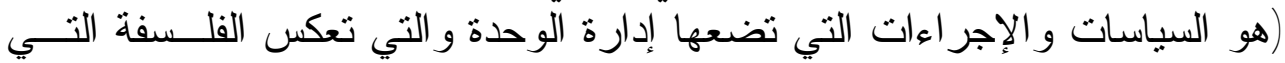

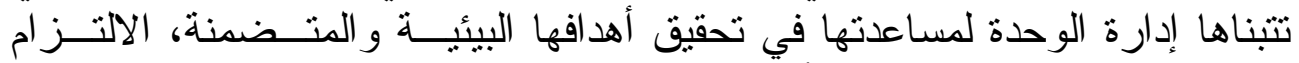

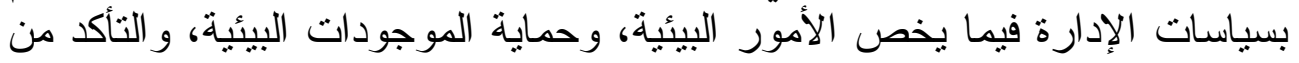

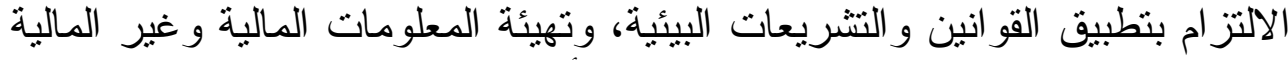

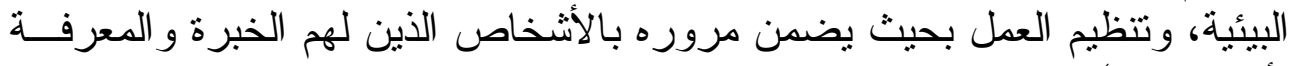
بأمور البيئة) .

1 -2 مكونات نظام الرقابة الداخلية

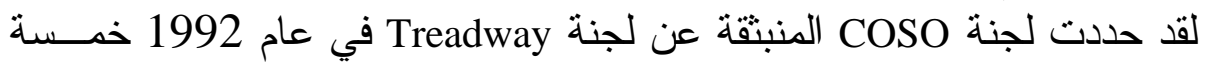
مكونات لنظام الرقابة الداخلية وهي (جمعة، 2000، 82) :

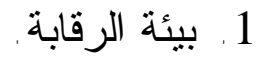

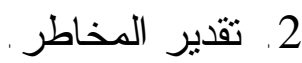

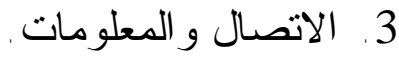

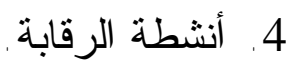
5. 5. 5 الثقييم (المتابعة).

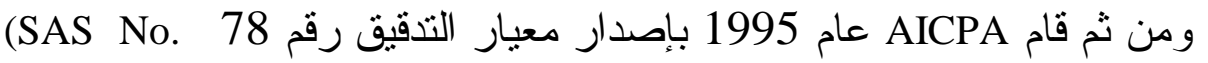

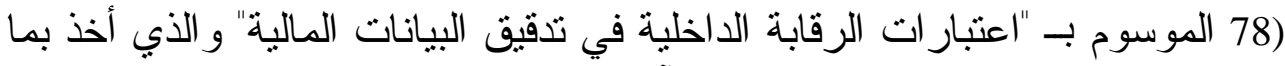

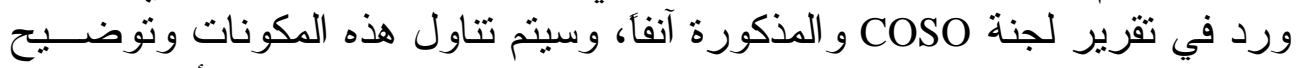
إنعكاساتها على نظام الرقابة الداخلية على تكاليف التلوث البنابة البيئي وكما يأني:

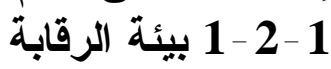

يقصد بييئة الرقابة السياسات و الإجر اءات التي تعكس اتجاهات الإدارة العليا

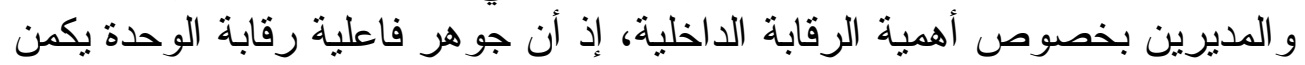




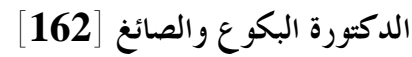

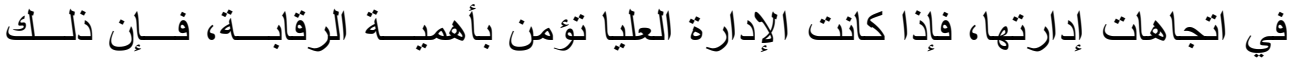

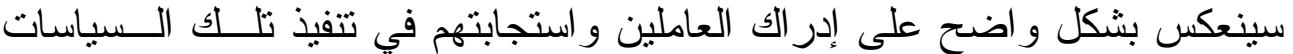

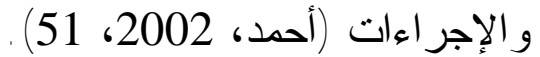

وتتضمن عوامل الحصول على فهم لبيئة الرقابة المتعلقة بالأمور البيئية الآتية

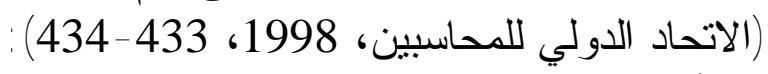
- ـ أداء وظائف مجلس الإدارة ولجانه، المتعلقة بالضو ابط البيئية للوحدة.

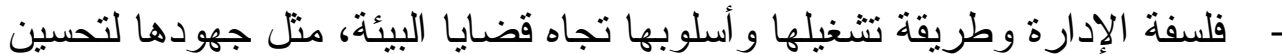

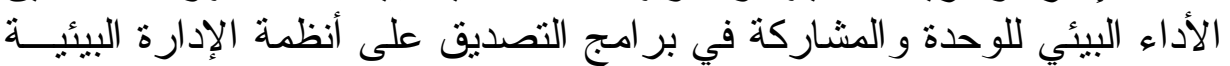

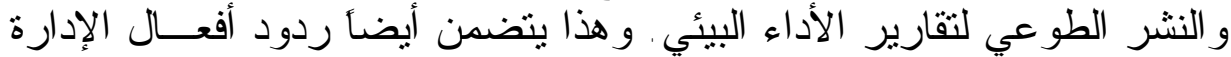

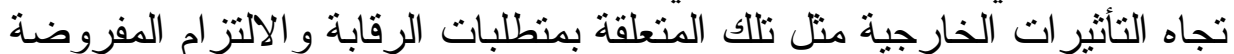

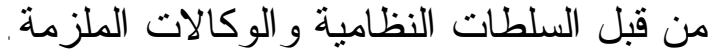
ـالهيكل التتظيمي للوحدة، وطر ائق إناطة الصلاحيات و المسؤوليات للتعامل مـــع الأنشطة و المتظلبات البيئية.

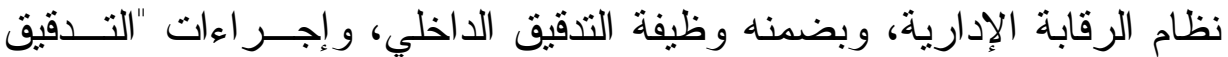

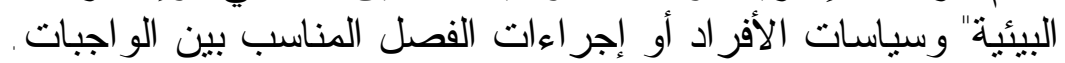

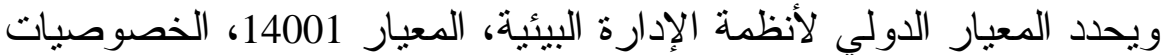

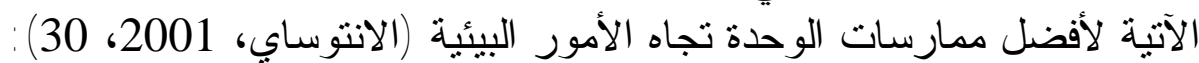

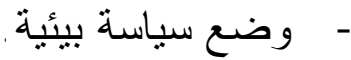

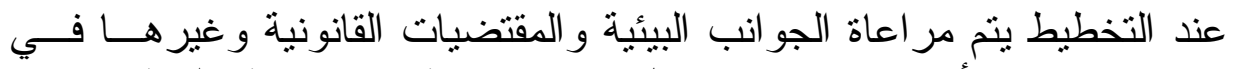

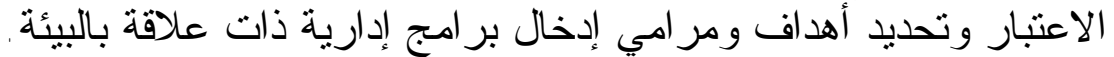

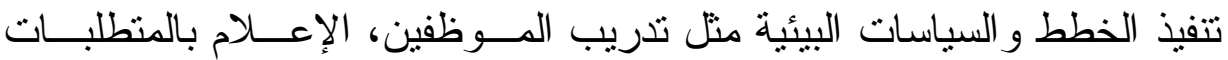

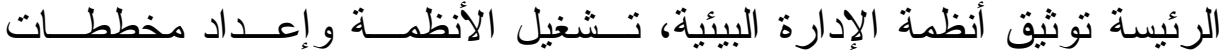

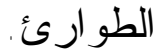

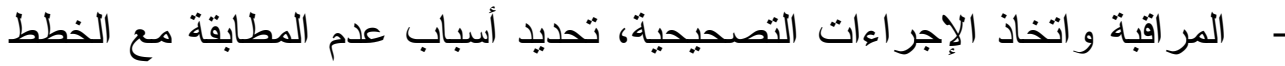
و اتخاذ الإجر اءات التصحيحية اللازمة ورقابة نظام الإدارة البيأئية. - - التذقيق الإداري لكافة جوانب النظام.

\section{2-2 1}

عرف الاتحاد الدولي للمحاسبين (IFAC) من خـــلال المعيــار رقــم (400)

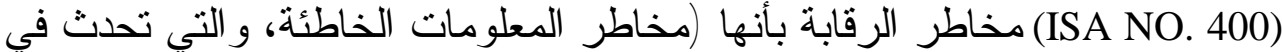

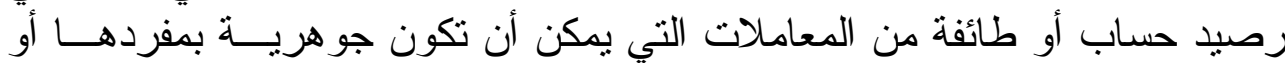

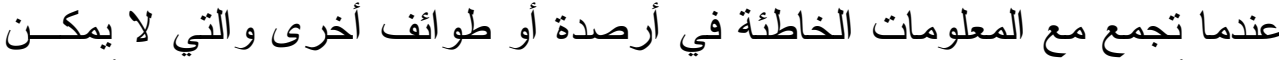

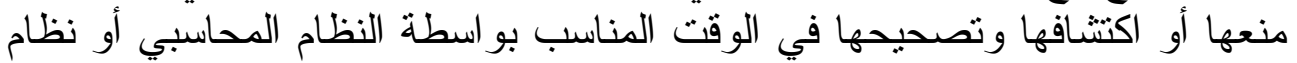

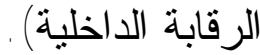




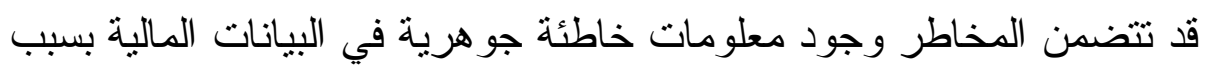

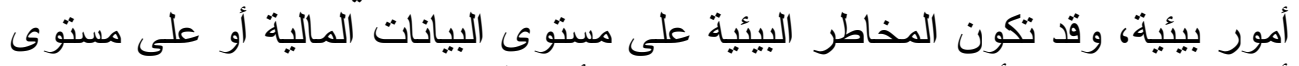

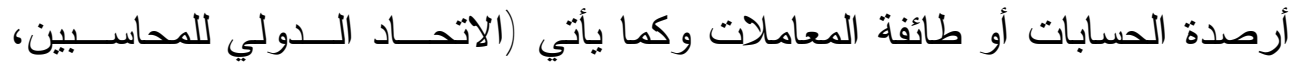
:432، 1998

أمثلة على المخاطر البيئية على مستوى البيانات المالية:

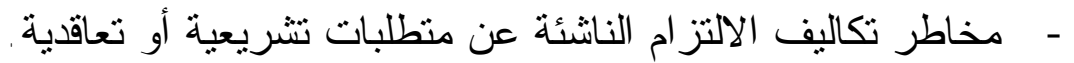

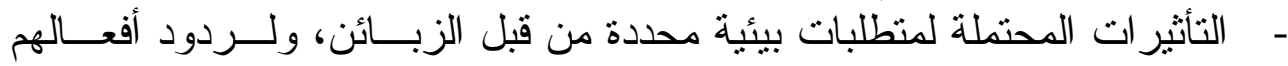
الممكنة حول التصرف البيئي للوحدة.

| 1

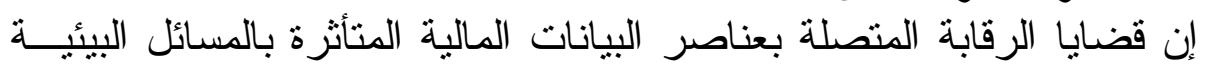

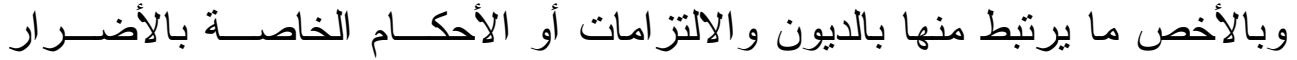

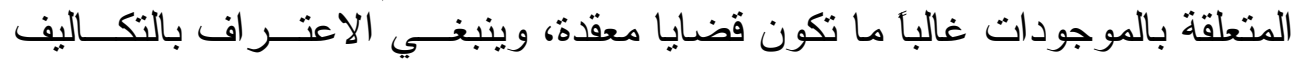

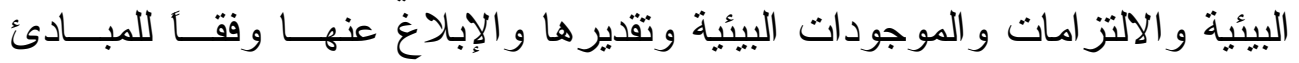

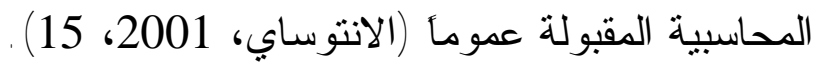

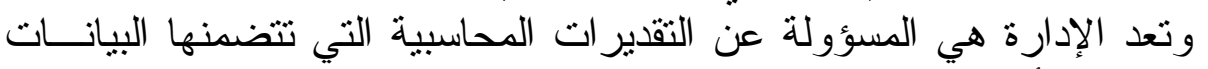

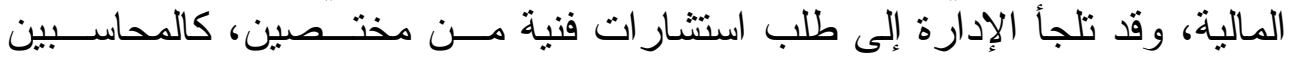

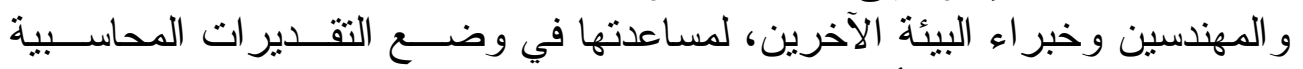

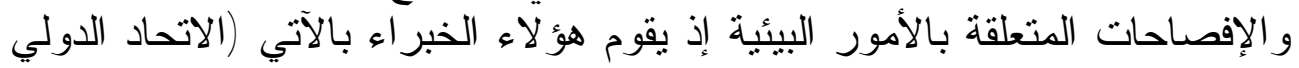
للمحاسبين، 1998، 437 -438)

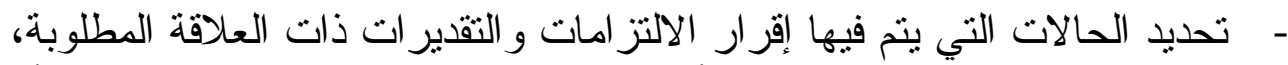

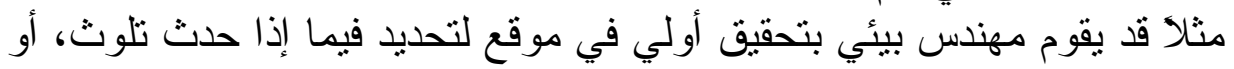

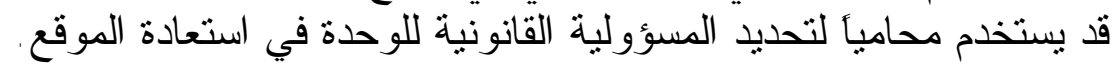

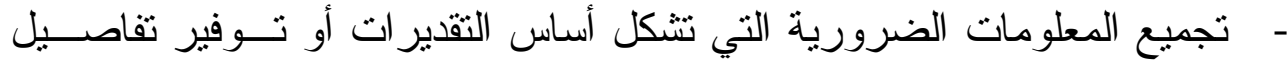

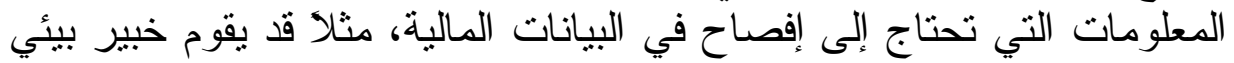

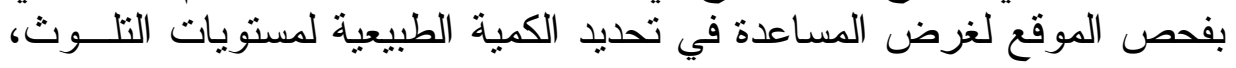
ودر اسة الطر ائق البديلة المقبولة في إصلاحة فيلاح الموقع.

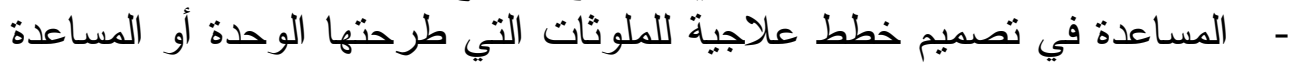
في احتساب تكاليف تلك الخطط. 4- 1 هي السياسات و الإجر اءات- فضلا عن بيئة الرقابة، التي وضعتها الإدارة لتحقيق أهداف الوحدة الاقتصادية (Elder \& Beasley, 2000, 295).

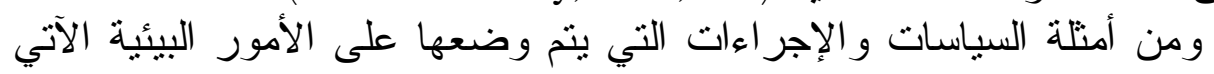

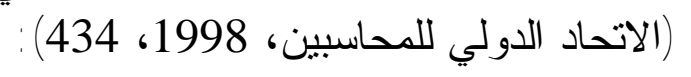




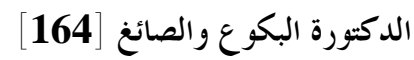

- مر اقبة الالتز ام بالسياسات البيئية للوحدة، فضلا عن الالتز ام بالقو انين و الأنظمة

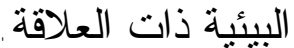

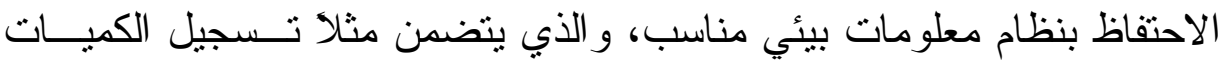

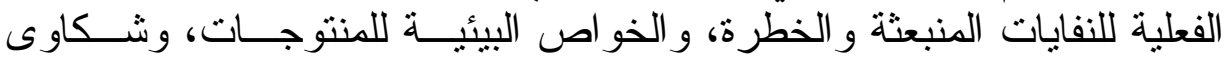

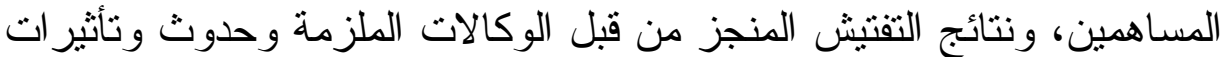

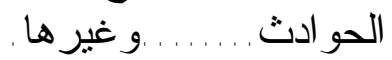

توفير مطابقات للمعلومات البيئية مع المعلومات المالية المناسبة، مثلا الكميات

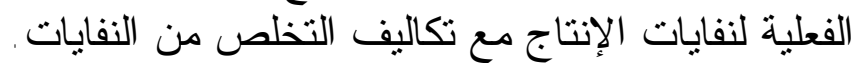
- ـ - تحديد الأمور البيئية المحتملة والطارئة ذات العلاقة التي تؤثر على الوحدة. 2- 1

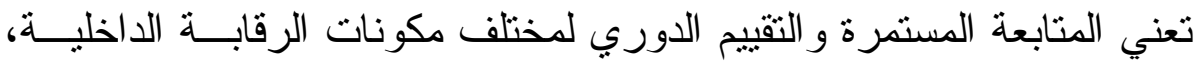

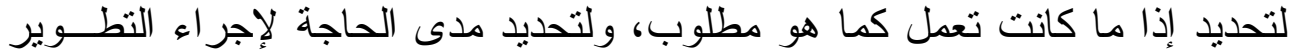

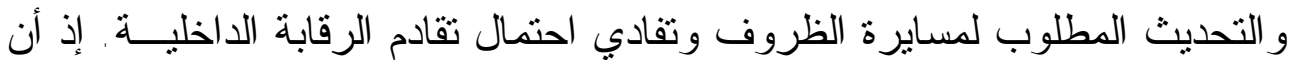

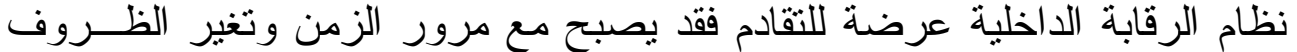

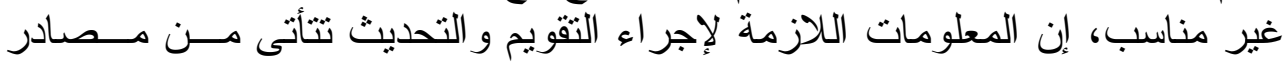

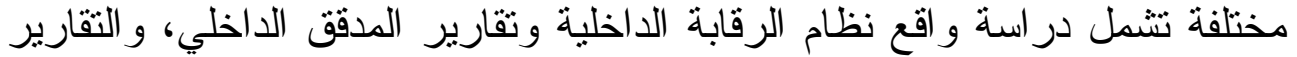

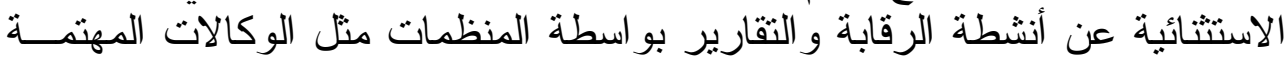

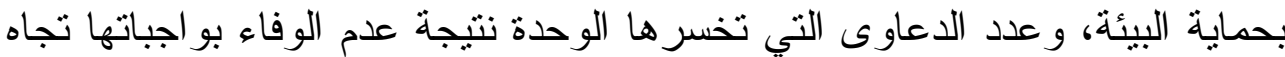
البيئة (Wiley \& Sons, 1997, 249).

\section{1 -3 متطلبات نظام الرقابة الاخلية على الأمور البيئية}

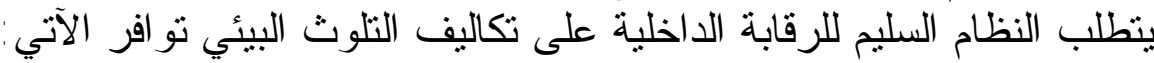

\section{| 1 - 1 - قو انين ومعاييير بيئية النظاية}

تهدف القوانين و المعايير البيئية إلى تحسين نوعية الحياة وظروفها للمو اطنين

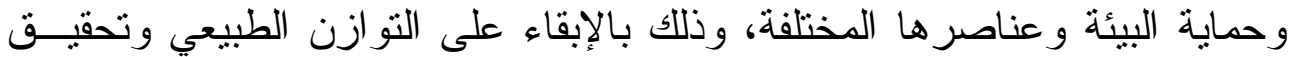

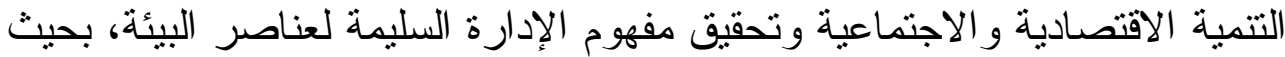

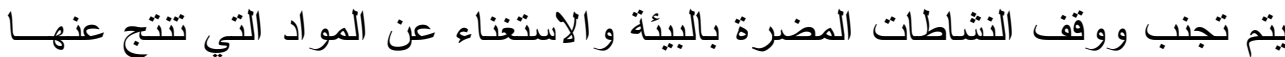

$$
\text { أخطار بيئية (الثراري، 1996، 19 10). }
$$

| 1

عرفت الإدارة البيئية من قبل البعض بأنها (جزء من الإدارة الكلية للوحسدة

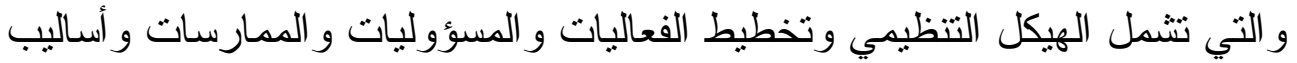

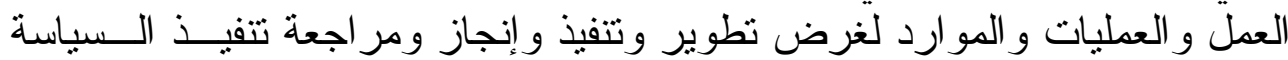

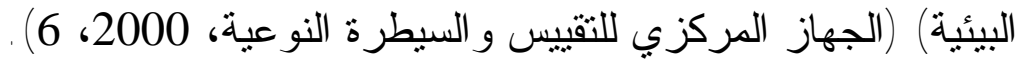




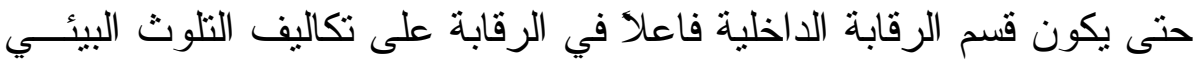

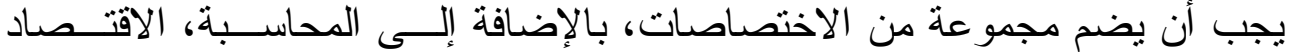

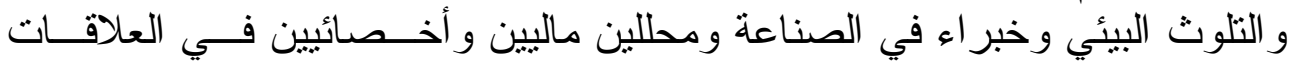
العامة (السقا، 1999، 330).

\section{| 3- 1}

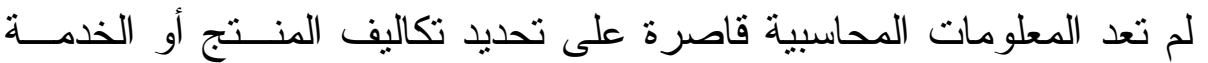

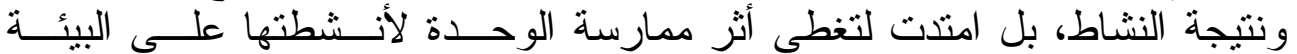

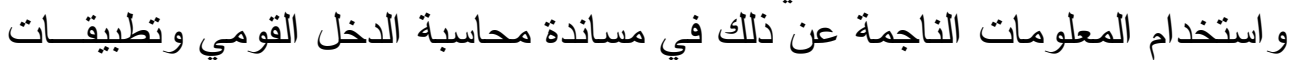

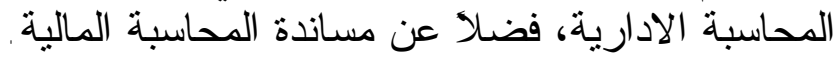

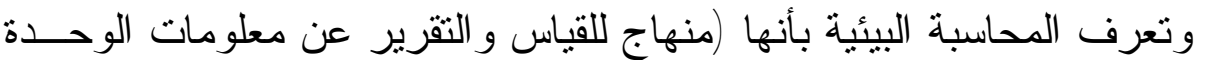

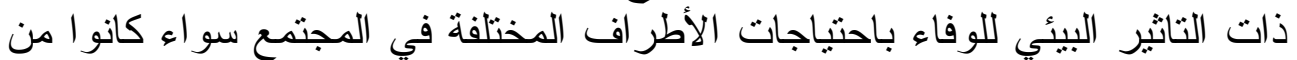

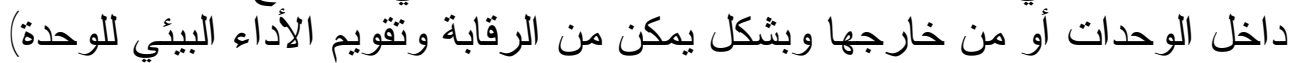

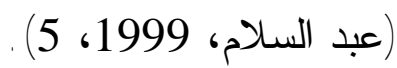

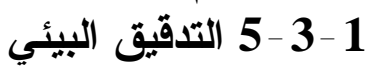
لقد عرفت وكالة حماية البيئة الامريكية / EPA التدقيق البيئي بأنه (عبارة عن

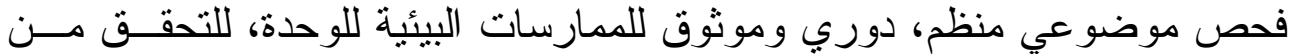

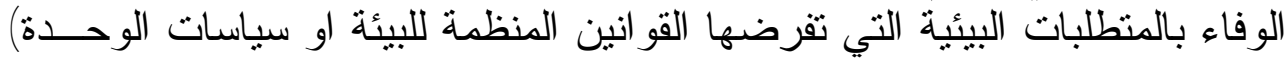
. (www.epa.gov/sbo/auditbook_500.pdf) ويرى الباحثان إمكانية تعريف التذقيق البئي الداخلي بأنـــهـ (أداة تــستخدمها

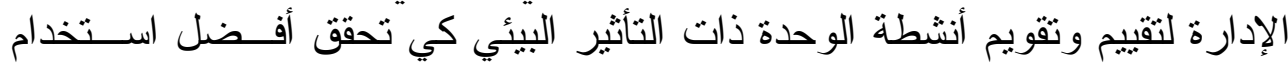

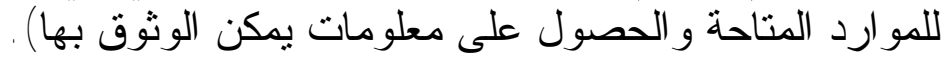

\section{و اقع نظام الرقابة الداخلية المطبق على تكاليف التلوث البيئي في الثركة العامــة}

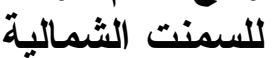

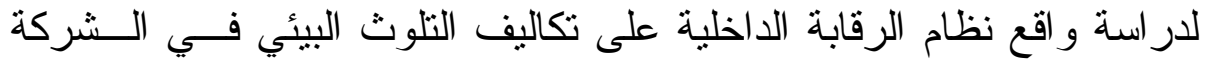

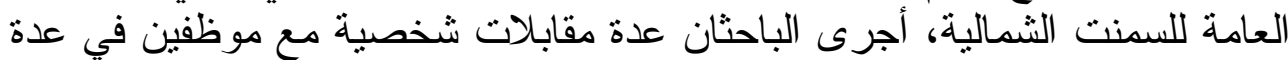

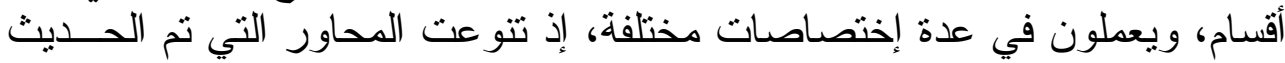

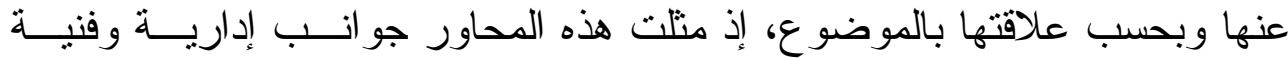

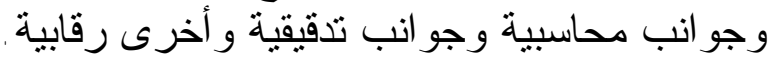
وسيتم التعليق على المقابلات الثخصية التي أجر اها الباحثنان مع الكابنة الكادر الفني

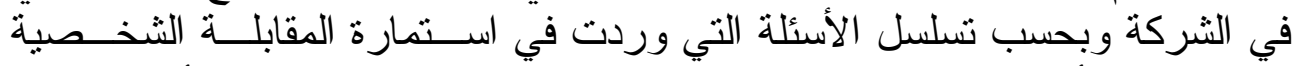

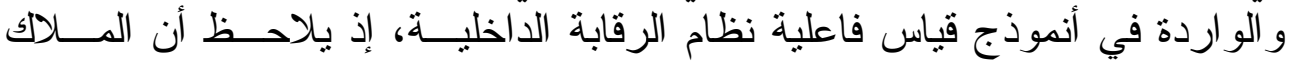

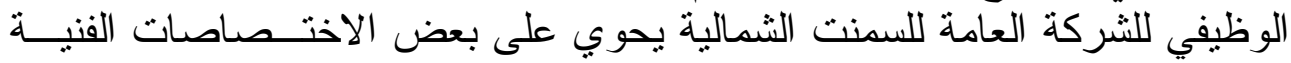

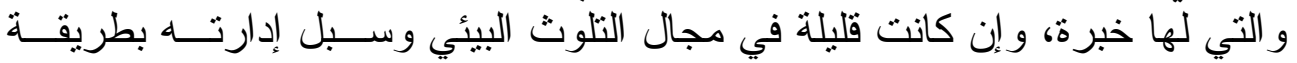

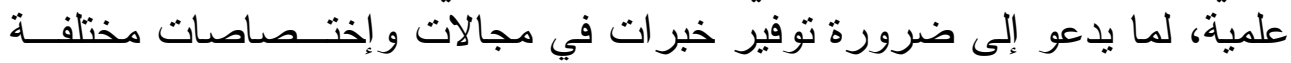




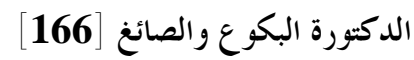

فضلا عن المحاسبة، منل الكيمياء و الطب و الهندسة وغيرها مــن الاختـ صاصات

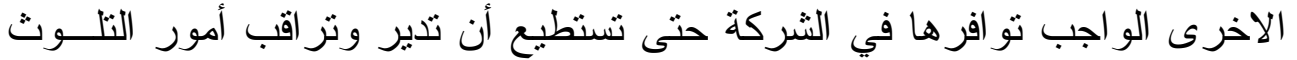

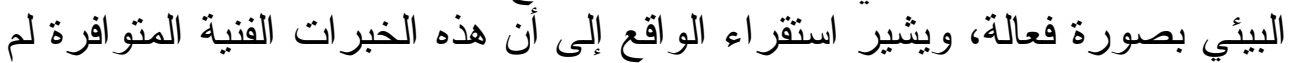

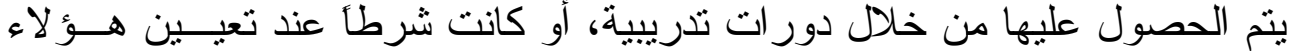

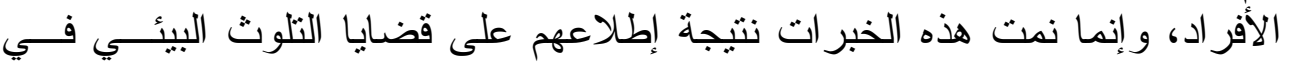

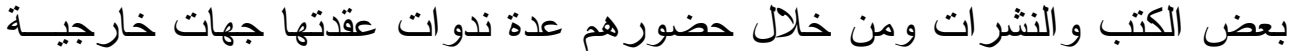

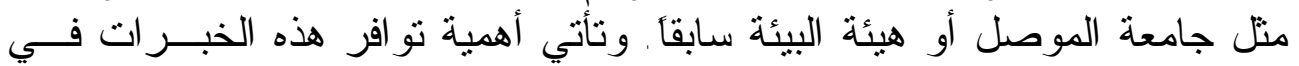

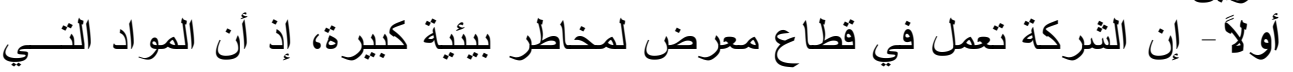

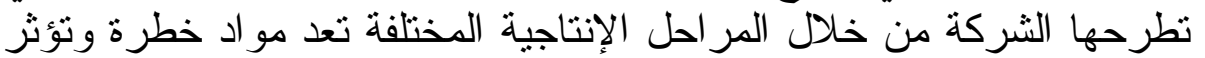

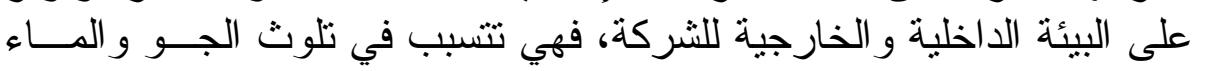

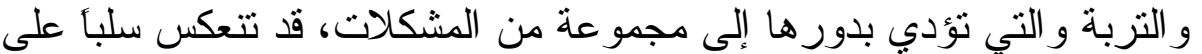

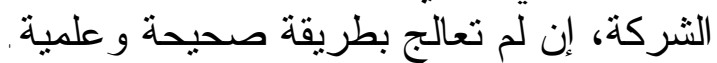

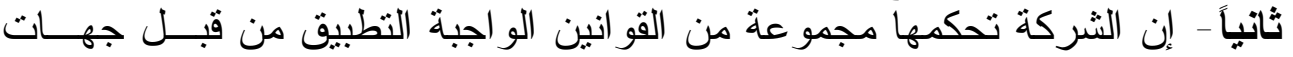

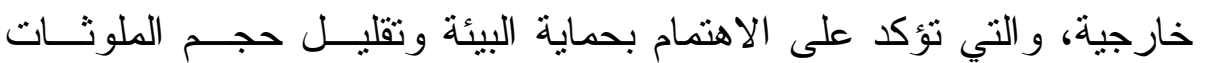
و النفايات التي تطرحها الثركة أثناء العملية الإنتاجية و إلا تعرضت لتراتية لمخاطر فرض غر امات و عقوبات.

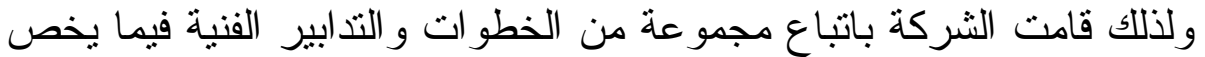

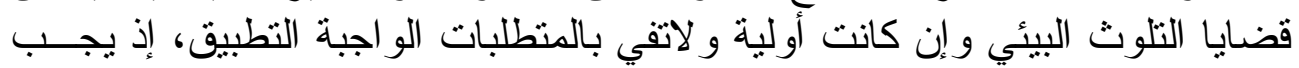

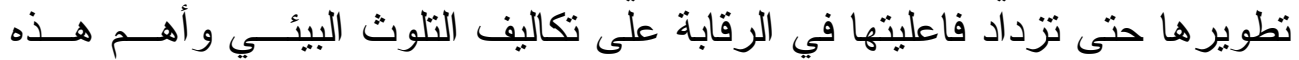

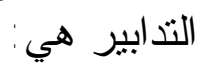
1. إنشاء قسم أو شعبة خاصة بكل معمل تابع لها مهتها الاهتمام ومتابعة قضايا

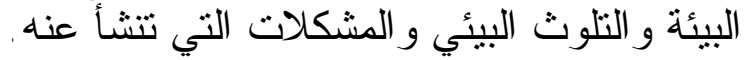

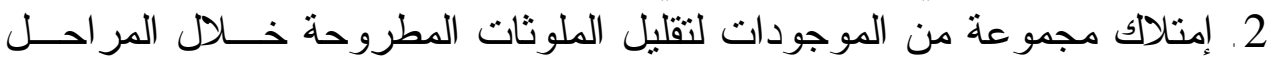

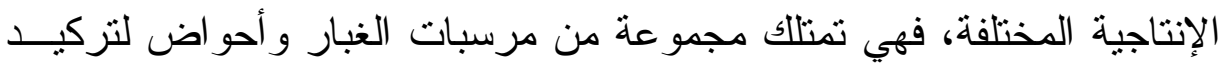

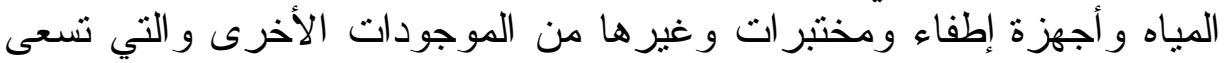

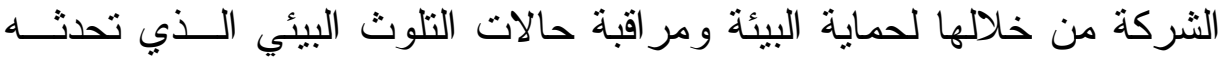

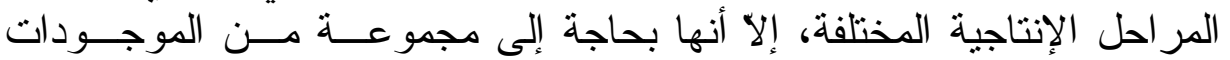

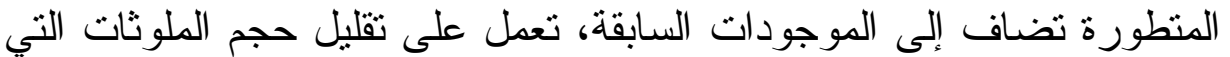

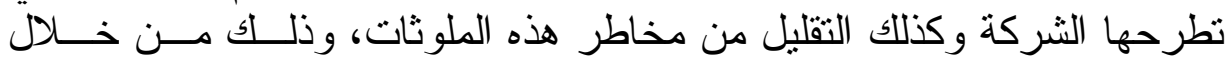
معالجتها بطر ائق علمية.

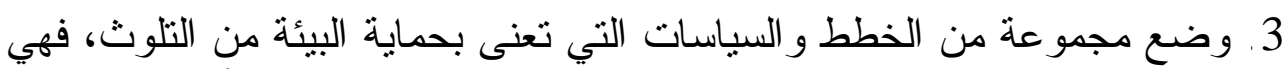

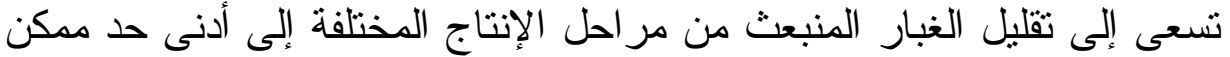

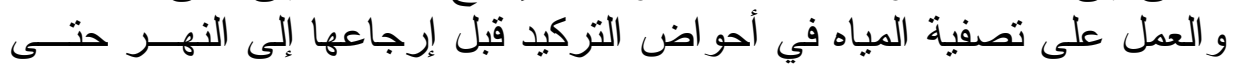
تخلي الثركة من مسؤولياتها تجاه الغير ل الغراه 


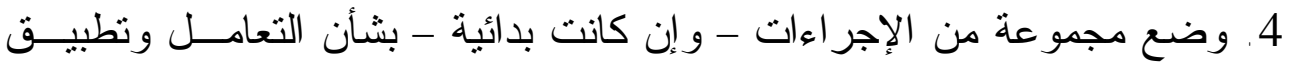

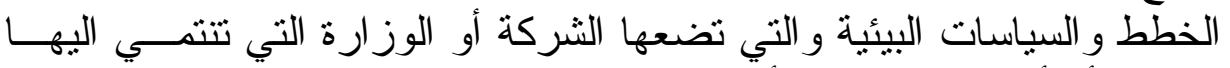
الثركة أو أي جهة خارجية أخرى تكلفها الدولة الاهتمام ومتابعة قضاياً التلوث الثيات

5. نشر بعض الاحصاءات عن مقادير الملوثات البيئية التي تطرحها الـشركة، إلائ

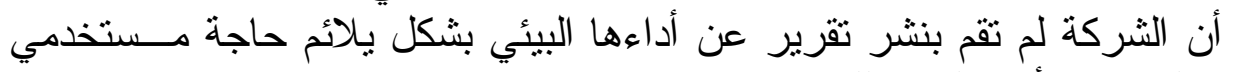

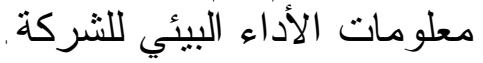

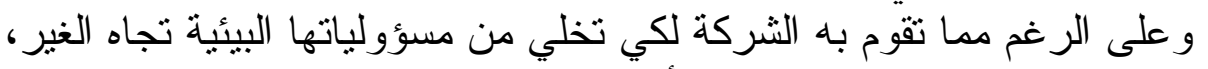

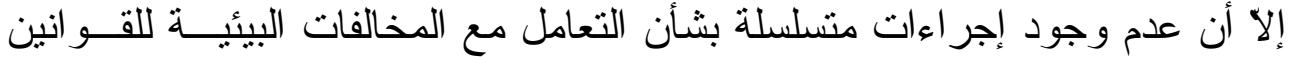

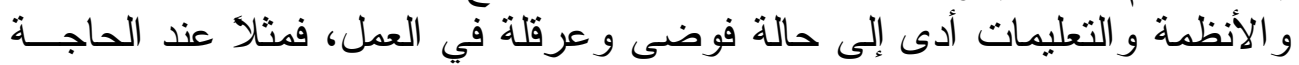

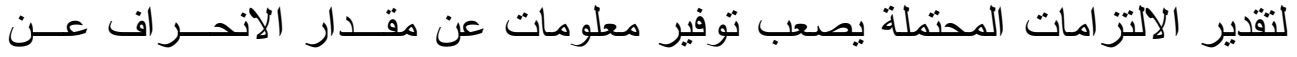

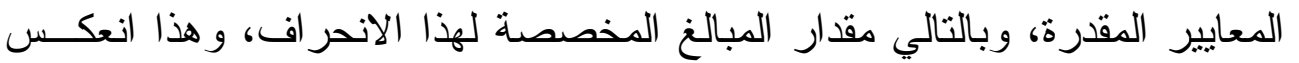

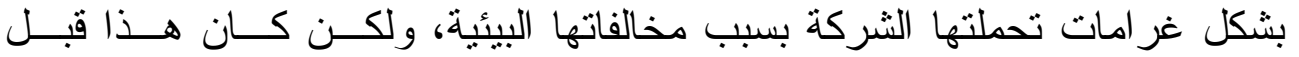

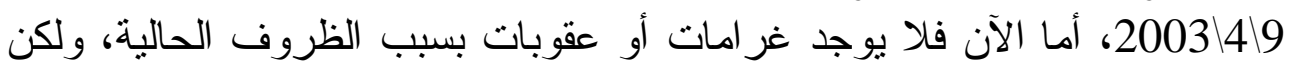

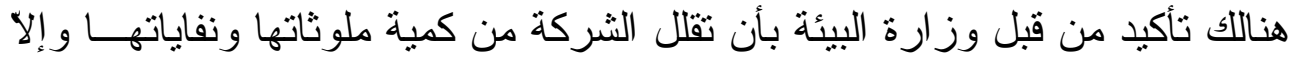

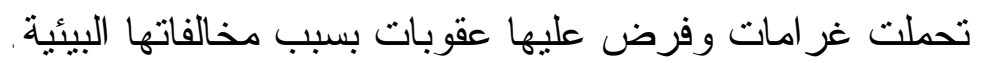

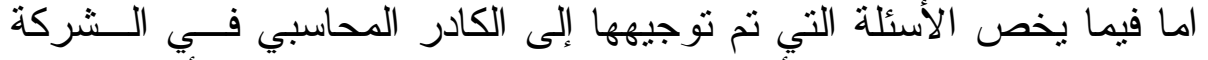

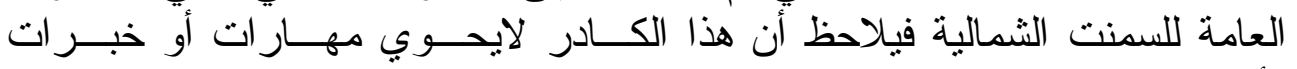

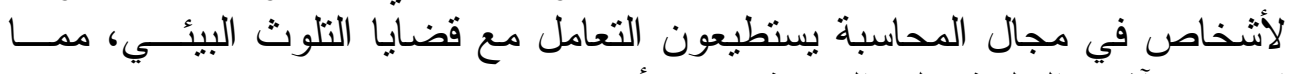

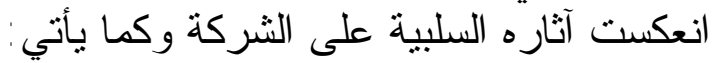

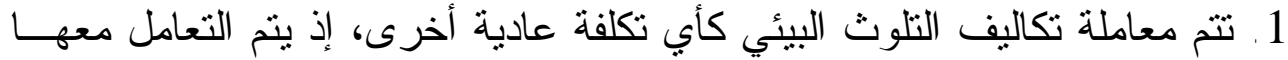

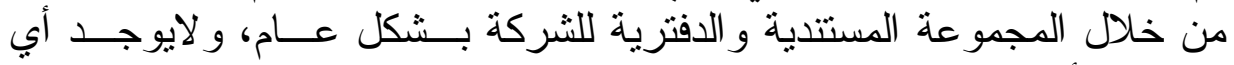

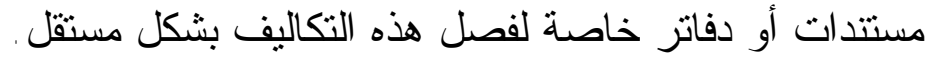

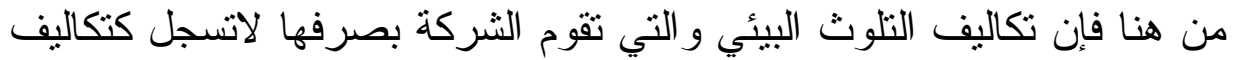

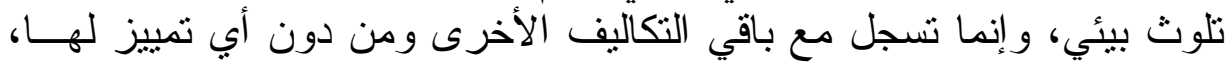

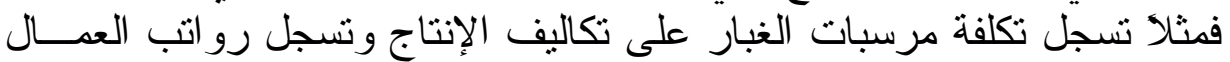

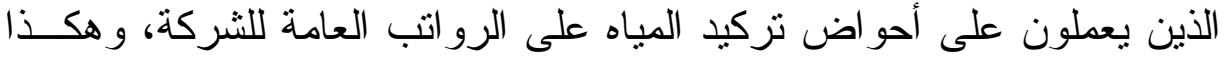

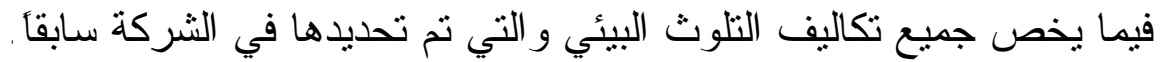

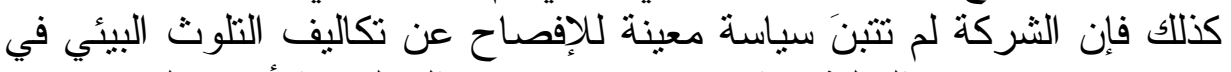

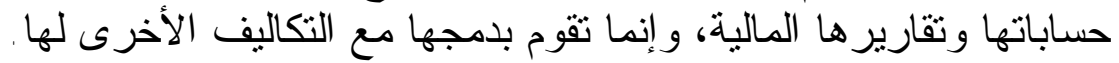

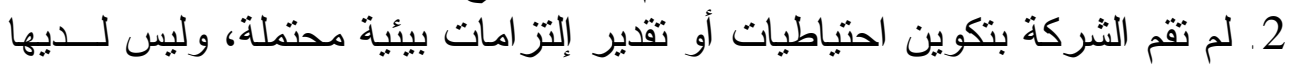

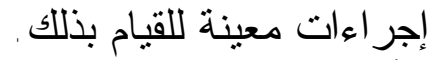

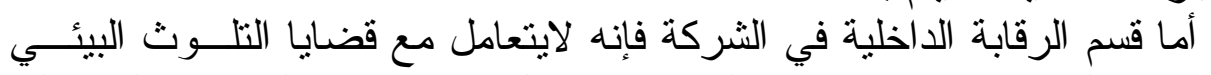

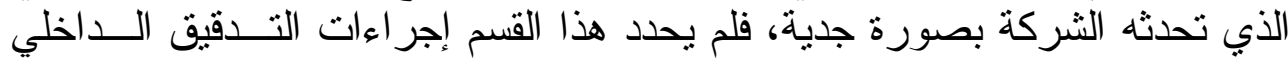
التي يفترض ممارستها، ولم يحدد حتى مجالات التنقيق البيئي التي يفترض القيــام 
[168] [الدكتورة البكوع و الصائغ

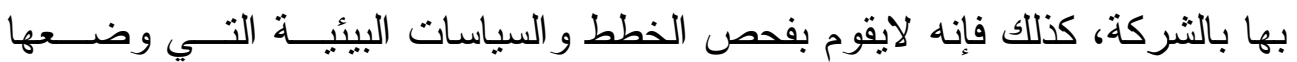

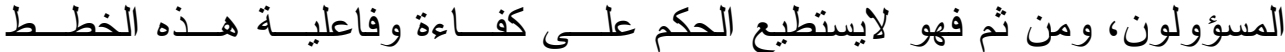

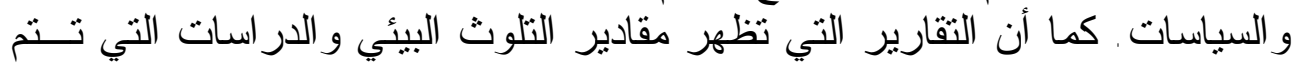
عن الملوثات البيئية وسبل معالجتها لايؤخذ رأي قسم الرقابة الداخلية فيها لئية

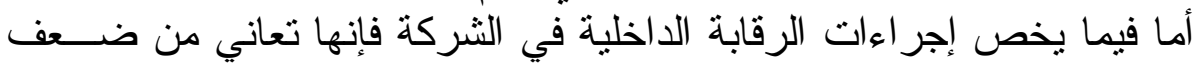
شديد فيما يخص تكاليف التلوث البيئي، ويبدو ذلك و اضحاً من خلابل الله الآتي:

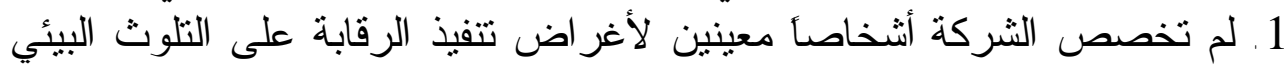
في الثركة.

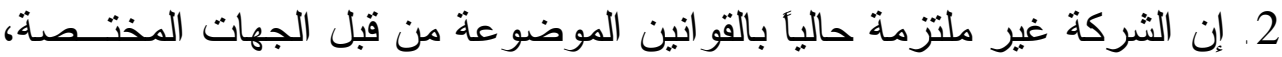

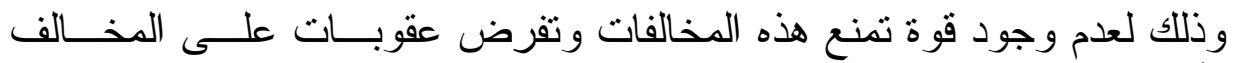
لأحكام القو انين و التعليمات .

3. فيما يخص الثكاوى البيئية التي ترفع ضد التئ الثركة، فلا توجد إجر اءات رقابيـــة

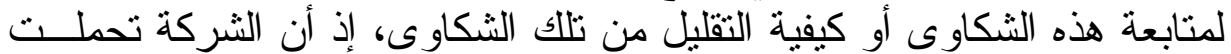

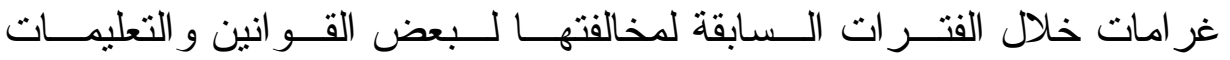
الموضو عة أمات.

4. ليس للشركة أي تعليمات أو نظام إداري أو نظام محاسبي مكتوب يعد مرجعـاً

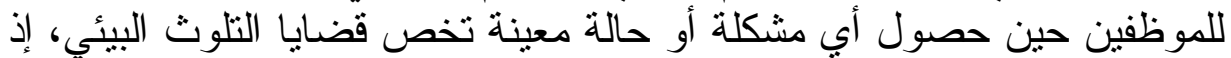

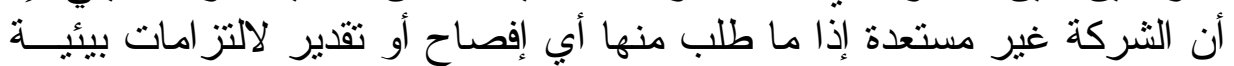

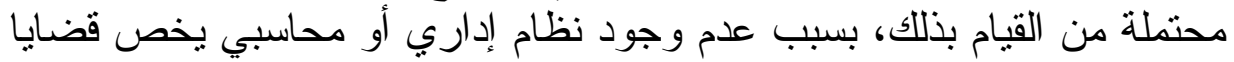

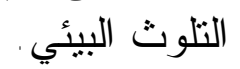

قياس درجة فاعلية نظام الرقابة الداخلية في الثركة على تكاليف التلوث البيأي

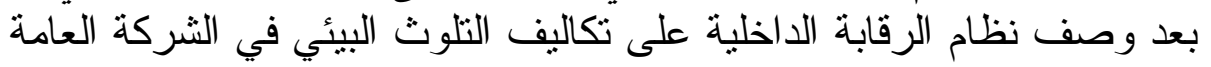
للسمنت الثمالية، سيقوم الباحثان بقياس فاعلية هذا النظام عن طريق المعادلة الآتية (عبد الله، 2000، 179): درجة الفاعلية = مجموع القيم المعطاة لأسئلة المجال نتيجة المقابلة/القيمة القياسية للمجال ×100

وقد قام الباحتثان بإعطاء أوز ان لكل مجال من مجالات الرقابة على تكــاليف

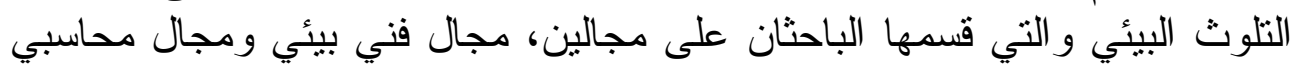
فضلا عن ذلك استخدم الباحثنان المدى من 1 - 5، إذ اعطى المجال الفنـي

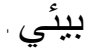
البيئي قيمة (4) و المجال المحاسبي البيئي قيمة (5) وكالآتي : 
- تحديد درجة فاعلية نظام الرقابة الداخلية على تكاليف التلوث البيئي فيما يخص

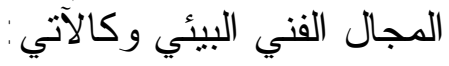

\begin{tabular}{|c|c|c|c|}
\hline \multicolumn{2}{|c|}{ الإجابة نتيجة } & \multirow{2}{*}{ القياسية } & \multirow[t]{2}{*}{ المجال : القني البيئي } \\
\hline$y$ & ن نعم & & \\
\hline 0 & 4 & 4 & 1. هل هناك قو انين و أنظمة ومعايير بيئية و اجبة النطبيق على \\
\hline 0 & 4 & 4 & 2. هل التلوث بكل شعبة خاصلة أو قسم خاص يهتم بأمور حماية البيأـــة \\
\hline 0 & 4 & 4 & 3. هل هناللك خطط معينة تعنى بحماية البيئة من التلوث . \\
\hline 0 & 4 & 4 & 4. هل هناللك إجر اءات معينة ومتسلسلة بشأن نطبيــق الــسياسات \\
\hline 0 & 0 & 4 & 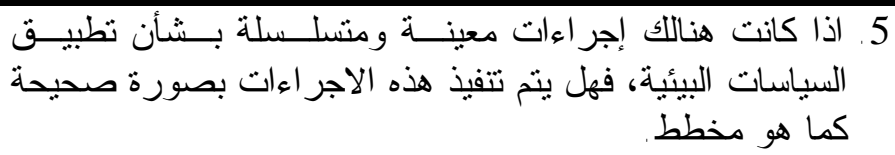 \\
\hline 0 & 4 & 4 & 6. هل معمل هنالك تقارير خاصة تظهر مقادير التلوث البيئي الناتج عن \\
\hline 0 & 0 & 4 & 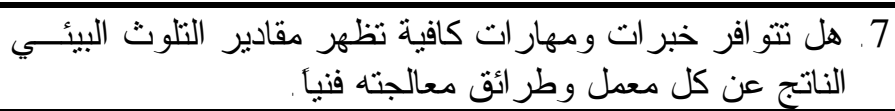 \\
\hline 0 & 0 & 4 & 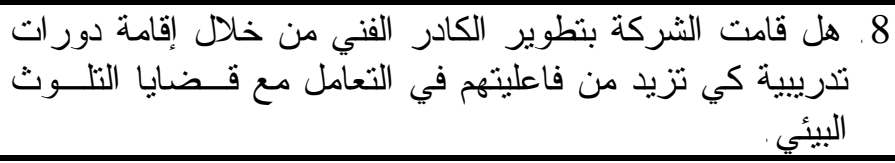 \\
\hline 0 & 0 & 4 & 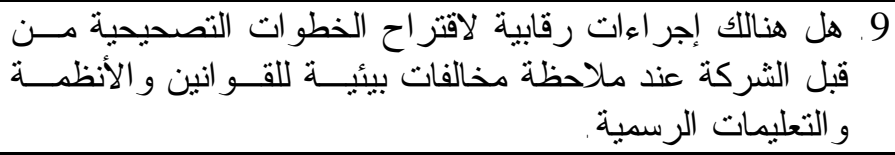 \\
\hline 0 & 0 & 4 & 10 فضائية بسبق للشبركة أنور بيئية. تحملت غر امات أو كان هنالك دعـاوى \\
\hline 0 & 0 & 4 & 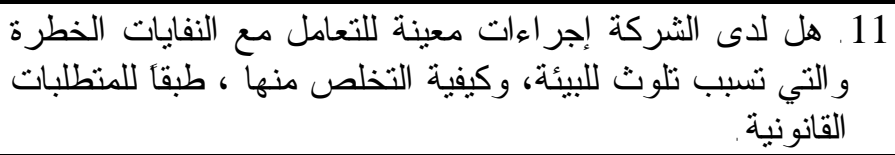 \\
\hline 0 & 0 & 4 & 12. هل قامت الثركة بنشر تقرير عن إدائها البيئي. \\
\hline 0 & 4 & 4 & 13. هل تمنلاك الشركة موجودات معينة لتقليـلـل حــالات التلـــوث \\
\hline
\end{tabular}


[170] الدكتورة البكوع و الصائغ

درجة فاعلية المجال الفني البيئي= مجموع الاجابة بنعم نتيجة المقابلة/القيم القياسية $100 \times$

$$
\begin{array}{r}
100 \times 52 / 24= \\
\% 46=
\end{array}
$$

- تحديد درجة فاعلية نظام الرقابة الداخلية على تكاليف التلوث البيئي فيما يخص

\begin{tabular}{|c|c|c|c|}
\hline \multicolumn{2}{|c|}{ الإجابة نتيجة المقابلة } & القيمة & \multirow{2}{*}{ المجال : المحاسبي البيئي } \\
\hline ע & نعم & القياسية & \\
\hline 0 & & 5 & 1. هل هنالك آلية معينة لتحديد المصاريف التي تخــص حمايــة \\
\hline 0 & & 5 & 2. هل تسيئة. بل الدصاريف التي تصرف لحماية البيئة كمـصـاريف \\
\hline 0 & & 5 & 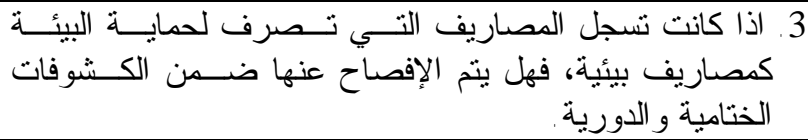 \\
\hline 0 & & 5 & 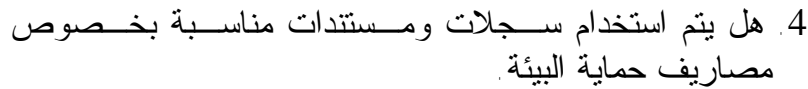 \\
\hline 0 & & 5 & 5. هلاليف تبنت حماية البيئةة. \\
\hline 0 & & 5 & 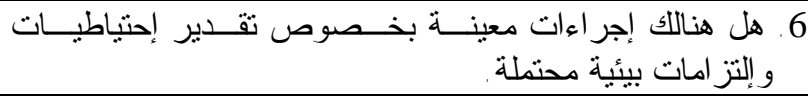 \\
\hline 0 & & 5 & 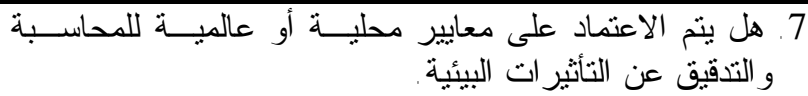 \\
\hline 0 & & 5 & 8. هل يتئ فحص وفليتها. الخطط البيئية لاختبار كفاءة البرامج و الانشطة \\
\hline 0 & & 5 & 9. هل يتم التأكد من صحارية البيئة. \\
\hline 0 & & 5 & 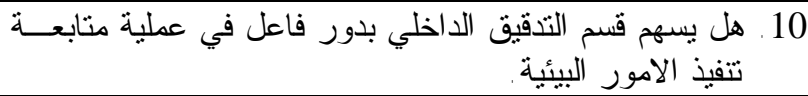 \\
\hline & 5 & 5 & 11. عند اتخاذ قرار استتماري كثر اء مكائن معينة، هل يتم أخـــذ \\
\hline 0 & & 5 & 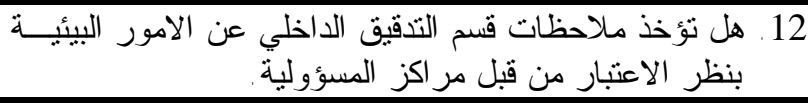 \\
\hline & 5 & 5 & 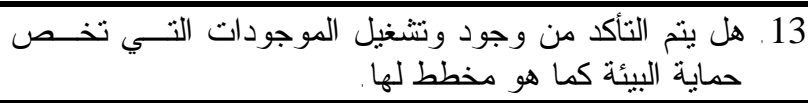 \\
\hline 0 & & 5 & 14. هل لدى الوحدة نظام إداري ومحاسبي محدد ومكتوب يعـــ \\
\hline
\end{tabular}
المجال المحاسبي البيئي وكالآتي: 


\begin{tabular}{|c|c|c|c|}
\hline \multicolumn{2}{|c|}{ الإجابة نتيجة المقابلة } & القيمة & \multirow{2}{*}{ المجال : المحاسبي البيئي } \\
\hline $\bar{y}$ & نعم & القياسية & \\
\hline & & & 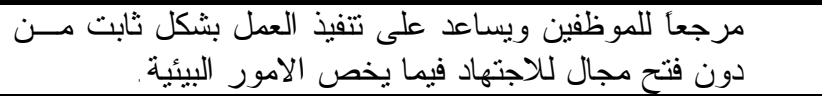 \\
\hline 0 & & 5 & 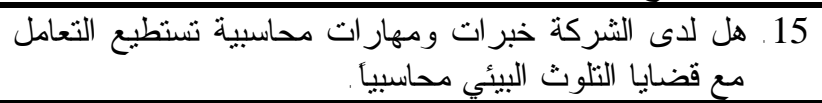 \\
\hline 0 & & 5 & 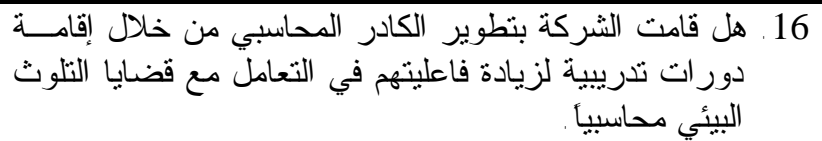 \\
\hline \multirow[t]{3}{*}{0} & & 5 & 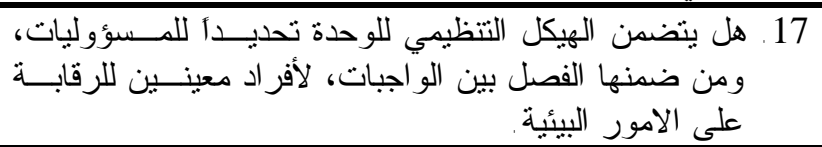 \\
\hline & 5 & 5 & 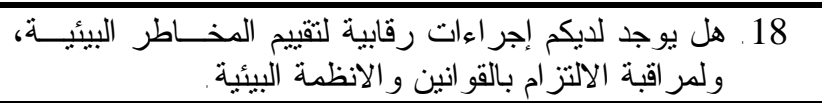 \\
\hline & 5 & 5 & 19 ـ هل لديكم إلجعراءة بأمور بيئية. لمعالجة من داخـلـل الــشركة أو \\
\hline \multirow[t]{2}{*}{0} & & 5 & 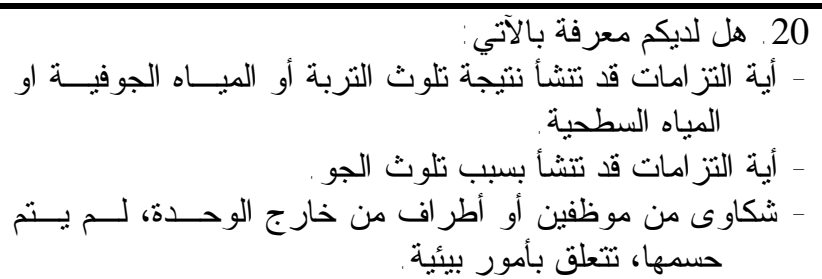 \\
\hline & 20 & 100 & مجموع القيم القياسية للمجال \\
\hline
\end{tabular}

درجة فاعلية المجال المحاسبي البيئي = مجموع الاجابة بنعم نتيجة المقابلة/القيم

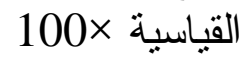

$$
\begin{array}{r}
100 \times 100 / 20= \\
\% 20=
\end{array}
$$

درجة فاعلية نظام الرقابة الداخلية على تكاليف التلوث البيئي = مجمــوع ع الاجابـــة

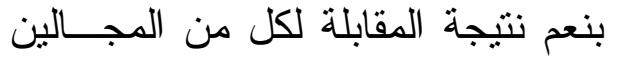

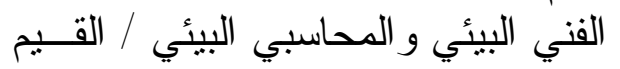

$$
\text { القياسية × } 100
$$

$$
100 \times 152 / 44=
$$

$$
\text { \% } 29=
$$

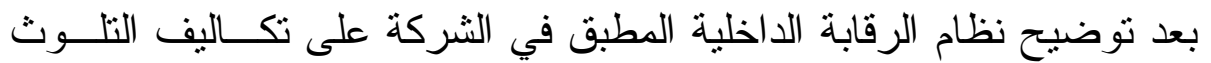

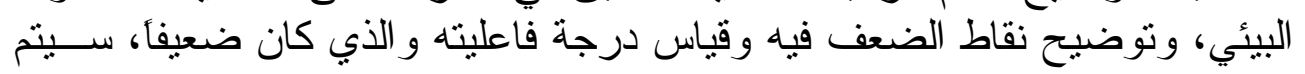




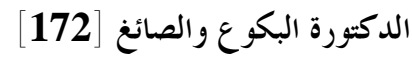

في فيما يأتي تطوير هذا النظام كي يصبح أكثر فاعلية في الرقابة علــى تكــاليف

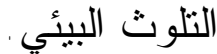

تطوير نظام الرقابة الداخلية على تكاليف التلوث البيئي في الثركة العامة للسمنت

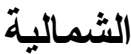

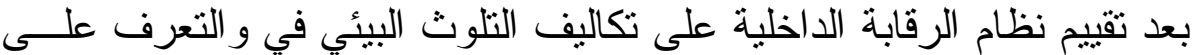

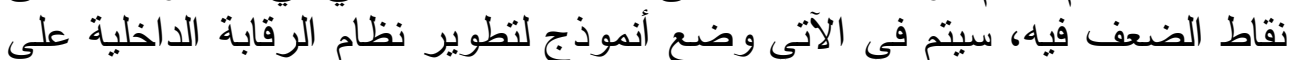

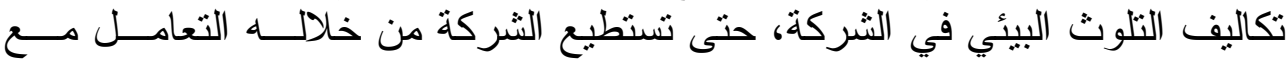

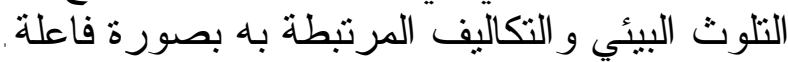
وسيقوم الباحثان بعرض الأنموذج على وفق الآتي:

1-3 أهداف الأنموذج المقترح

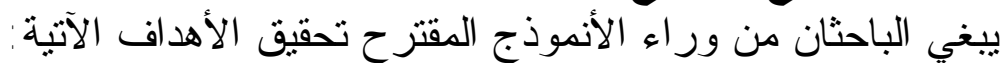

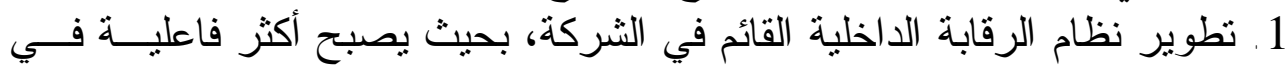
الرقابة على تكاليف التلوث البيئي.

2. تحديد عناصر تكاليف التلوث البيئي في الثركة و التني سيتم معالجتها من خلال إجر اءات الأنموذج المقتر ح.

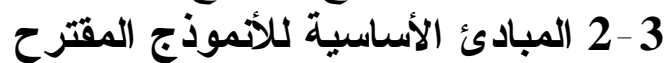

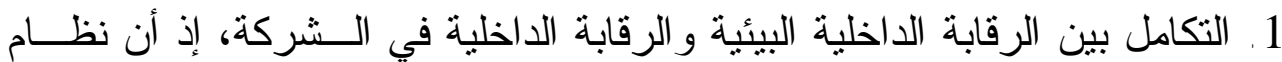

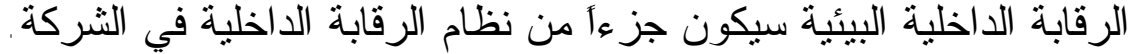

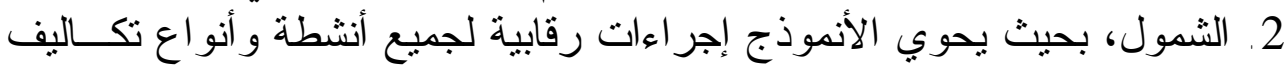
التلوث البيئي.

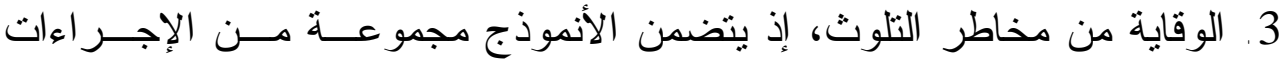

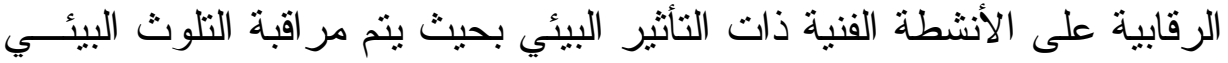

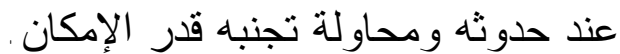
3 -3 تصنيف وترميز تكاليف التلوث البيئي

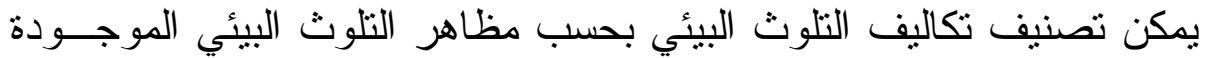

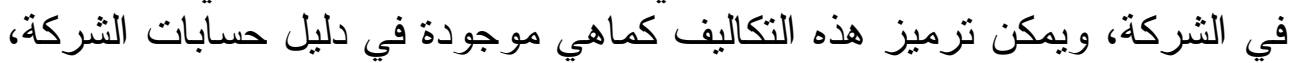

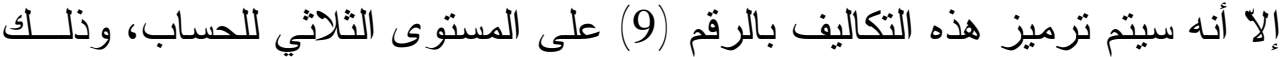

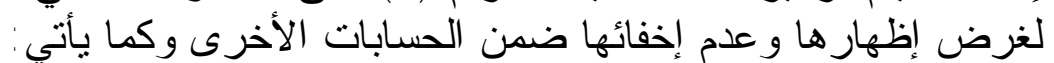

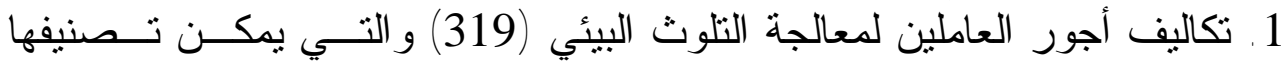

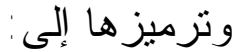

- أجور العاملين لمعالجة التلوث الجوي، ويرمز لها بالرقم (3191) .

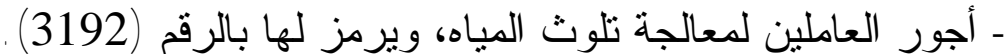


- أجور العاملين لمعالجة التلوث الضوضائي، ويرمز لها بالرقم (3193) .

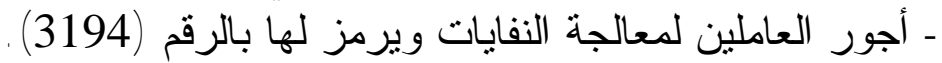

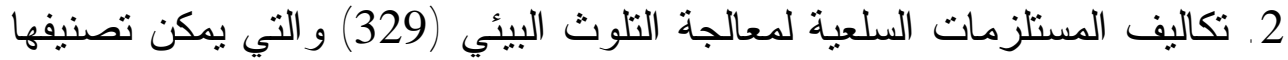

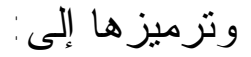

- تكاليف المستلزمات السلعية لمعالجة التلوث الجوي، ويرمز لهــا بــالرقم

ـ تكاليف المستلزمات السلعية لدعالجة تلوث المياه، ويرمـز لهــا بــالرقم

ـ تكاليف المستلزمات السلعية لمعالجة التلوث الضوضائي، ويرمـز لهـــا

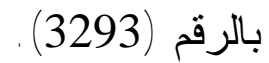

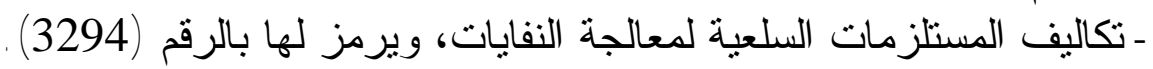

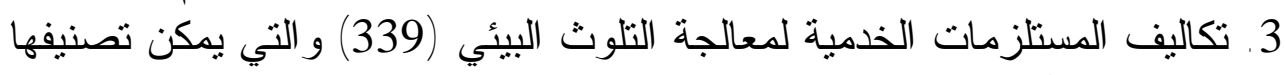

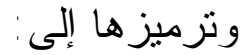
ـ تكاليف المستلزمات الخدمية لمعالجة التلوث الجوي، ويرمز لها بــالرقم ـ تكاليف المستلزمات الخدمية لمعالجة تلوث المياه، ويرمـز لهــا بــالرقم . (3392) ـ تكاليف المستلزمات الخدمية لمعالجة التلوث الضوضائي، ويرمـز لهــا

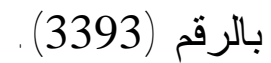
ـ تكاليف المستلزمات الخدمية لمعالجــة النفايــات، ويرمــز لهــا بــالرقم . (3394) 4. تكاليف اندثار الموجودات المخصصة لمعالجة التلوث البيئي (379) و التي يمكن تصنيفها وترميز ها إلى: ـ تكاليف اندثار الموجودات المخصصة لمعالجة التلوث الجوي، ويرمز لها

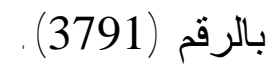
ـ تكاليف اندثار الموجودات المخصصة لمعالجة تلوث المباه، ويرمز لهــا

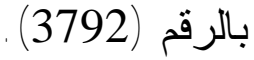

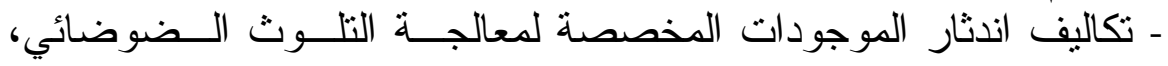

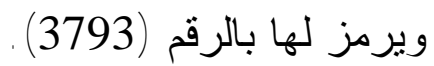
- تكاليف اندثار الموجودات المخصصة لمعالجة النفايات، ويرمز لها بالرقم 5. تكاليف الغرامات و العقوبات التي تتحملها الثركة بسبب التلوث البيئسي الـــي تحدثه (389) و التي يمكن تصنيفها وترميز ها إلى: 


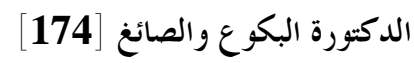

- تكاليف الغرامات و العقوبات التي تتحملها الثركة بسبب التلوث الجوي،

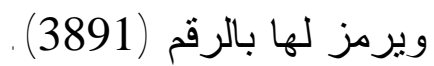

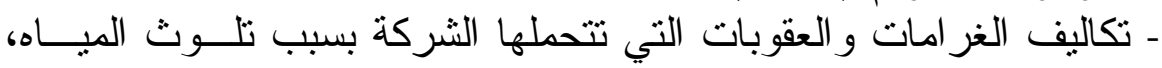

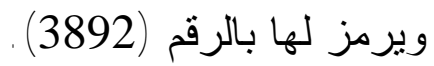

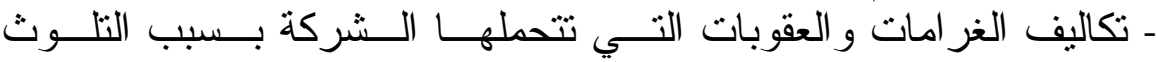

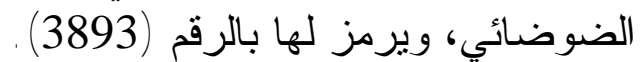

ـ تكاليف الغر امات و العقوبات التي تتحملها الثركة بسبب النفايات، ويرمز

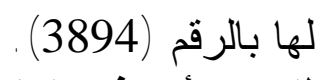

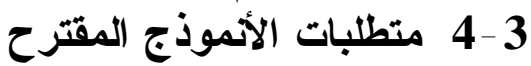

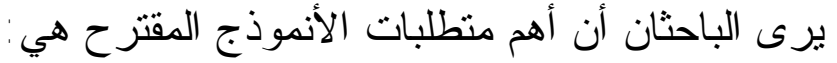

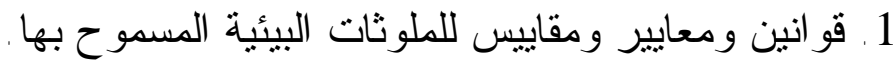

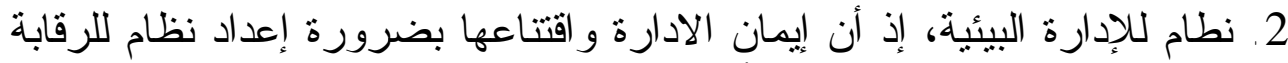
على تكاليف النلوث البيئي يعد أمرأ مهمأ. 3. كادر وظيفي له الخبرة و الكعرفة الكافية بأمور الرقابة البيئية. 4. نظام للمحاسبة عن تكاليف التلوث البيائي.

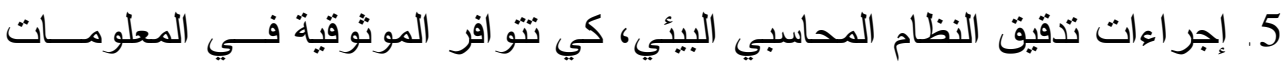

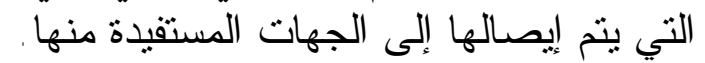

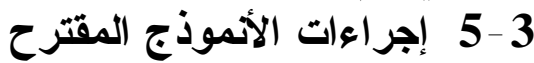

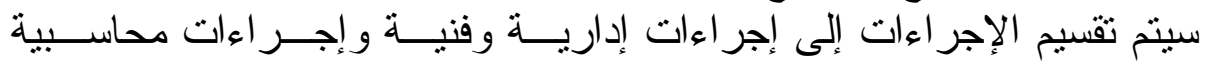

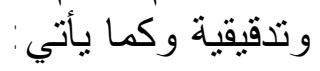

أو 3 - 3 - الإجراءات الإدارية و والفنية

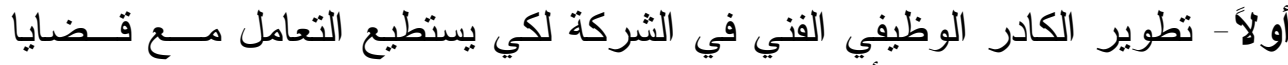

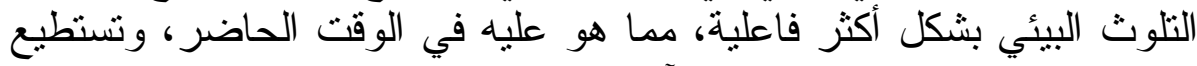
الثركة تطوير الكادر من خلاد الآتي: الكادئ 1. زيادة اختصاصات الكادر الفني، متل تعيين أطباء وكيميائيين لهم معرفة وخبرة في قضايا النلوث البيئي.

2. إقامة دور ات داخلية ولمختلف الاختصاصات الفنية، وذللك من خلال الاســتعانة

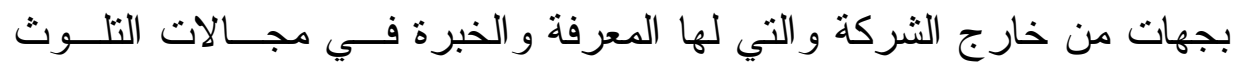
البيئي.

3. المشاركة في ندو ات تكون أهدافها زيادة الوعي لدى الكادر الفني فــي قــــايا

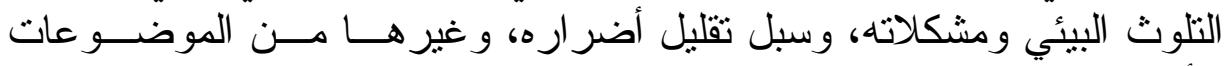

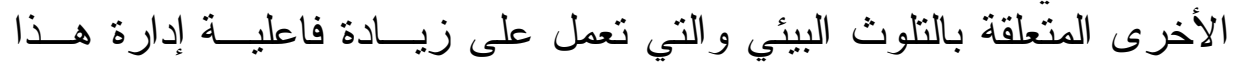

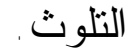


4. الاستعانة بجهات استشارية لها الخبرة و المعرفة في مجالات التلوث البيئي كـي لئي

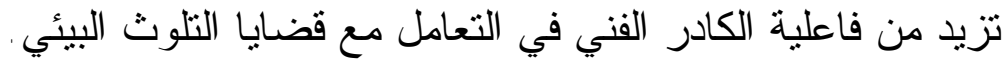
5. انشر الك الثركة ببعض المجلات و النشرات التي تهتم بقضايا التلوث البيئي.

ثانياً - تطوير الاجر اءات و التنابير الفنية التي تتبعها الــشركة لغـرض الــسيطرة و إدارة التلوث البيئي كما يأتي:

1. فيما يخص القسم الذي يهتم بقضايا التلوث البيئي بكل معمل، علـى الــشركة تطويره من النواحي الآتية: أ. تتويع الاختصاصات التيات التي تعمل فيه، و التي يكون لها القدرة على التعامل مع

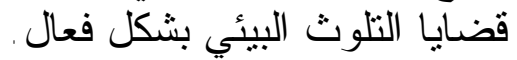

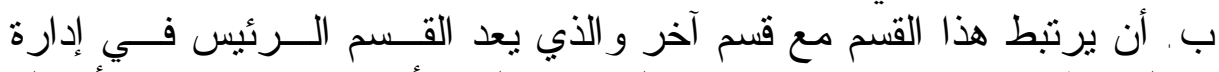

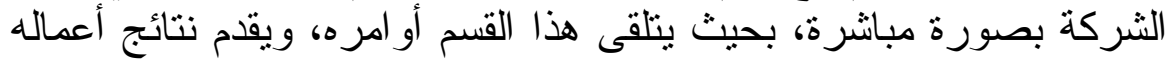

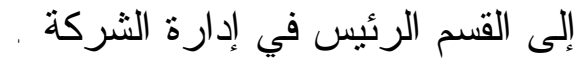

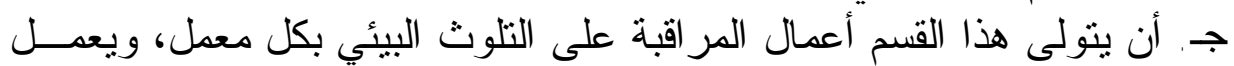

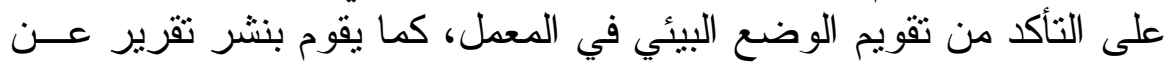

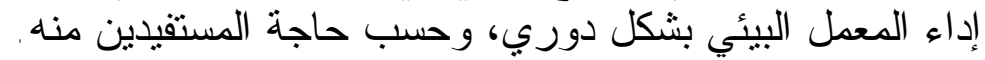

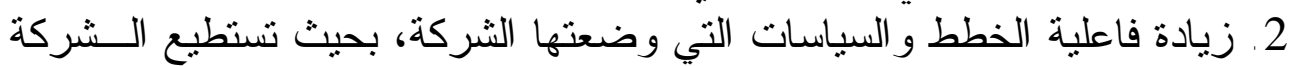

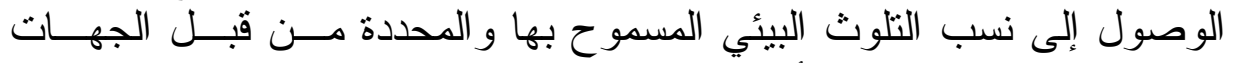

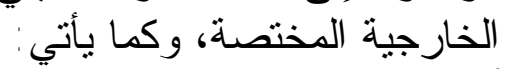
أ. تخفيض الملوثات الني تطرحها الثركة بحيث تصل إلى النسب المسـسوح

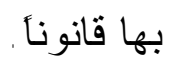

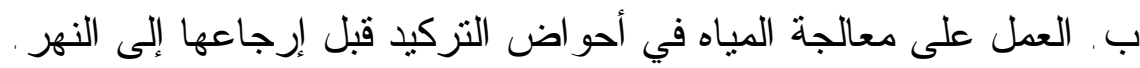

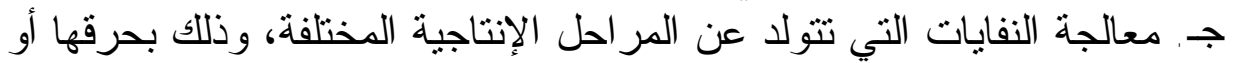

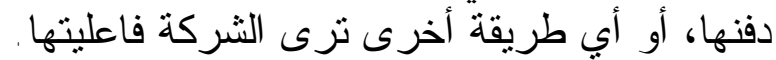

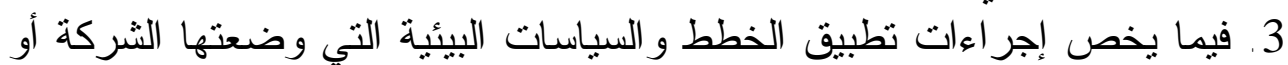

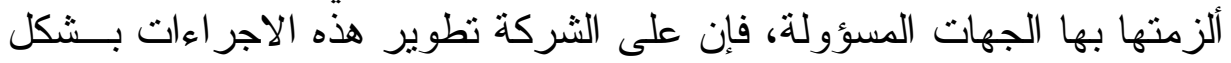

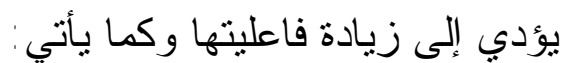

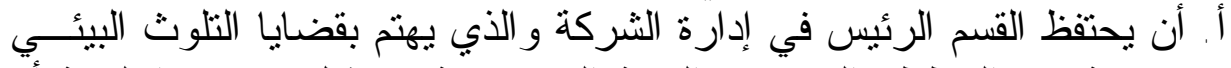

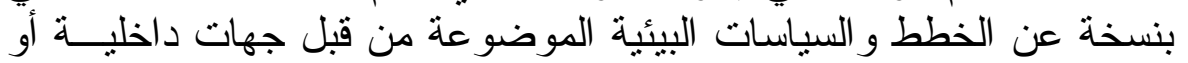

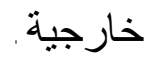

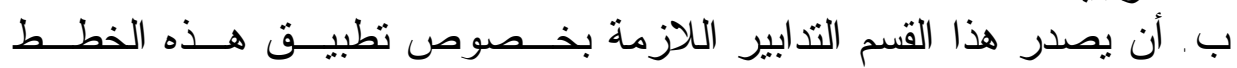

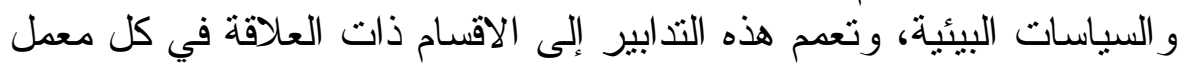

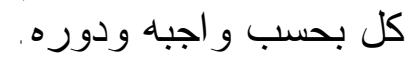
جـ. أن ترفع هذه الاقسام تقارير دورية إلى القسم الرئيس فــي إدارة الــشركة

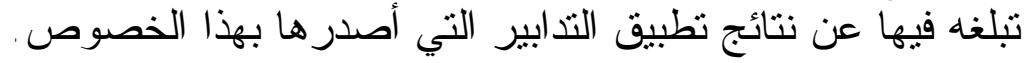




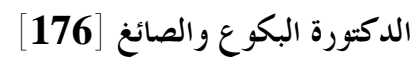

د. . يرفع القسم الرئيس تقريره إلى الرقابة الداخلية في الثركة، حتى يتم تدقيقها

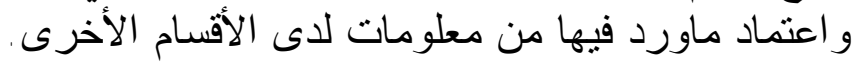

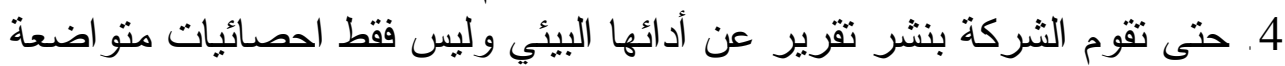
عن ملوثاتها البيئية عليها القيام بالآتي:

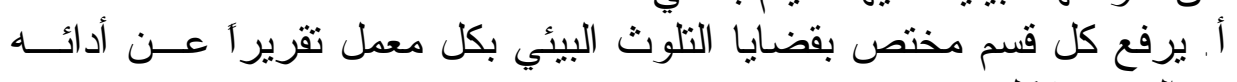

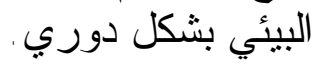
ب. يقوم القسم الرئيس المسؤول عن قضايا التلوث البيئي فـي إدارة الــشركة بتجميع تقارير الاقسام بكل معمل بتقرير واحد، ويصدر عن الثنائ الثركة بصورة

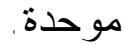
جـ. يقوم قسم الرقابة الداخلية في الثركة بتدقيق ما ورد في التثرير الموحد من

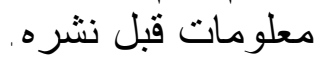

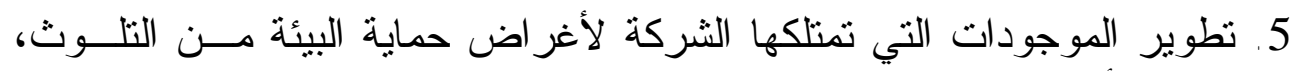

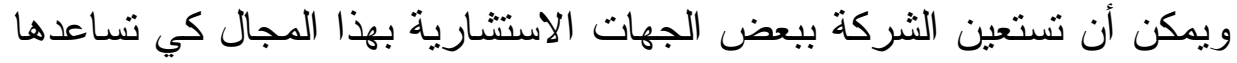

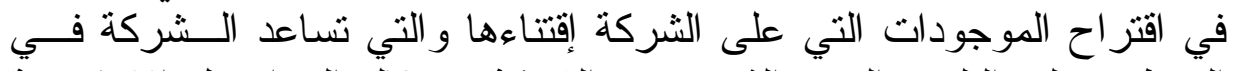

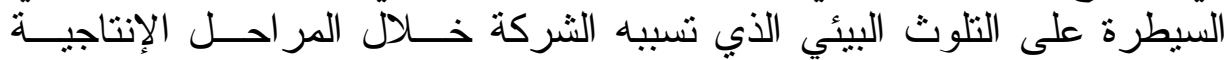

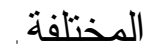

3 -5 -2 الاجر اءعات المحاسبية والتدقيقية

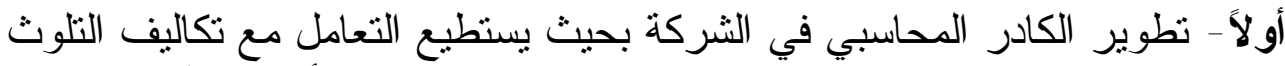
البيئي و الصعو بات التي تحكمها، ويتم ذللك بعدة طر ائق أهمها الآتي:

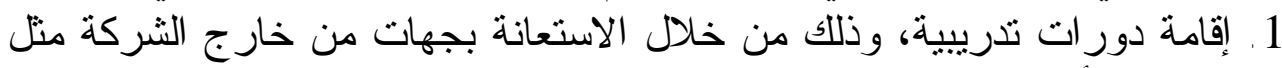

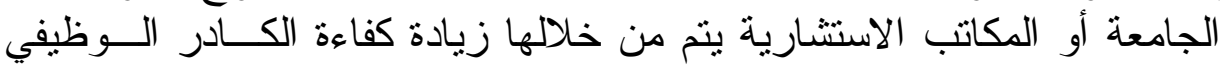

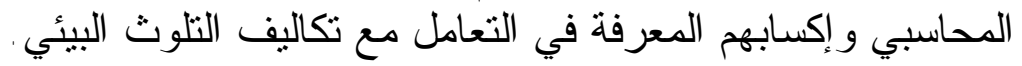

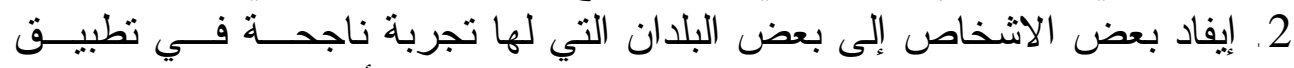

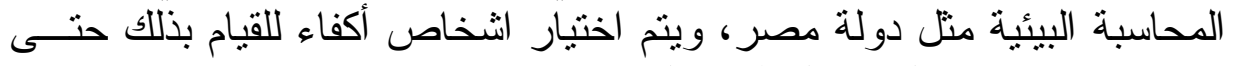

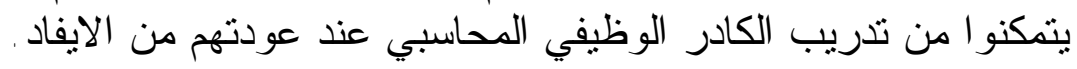

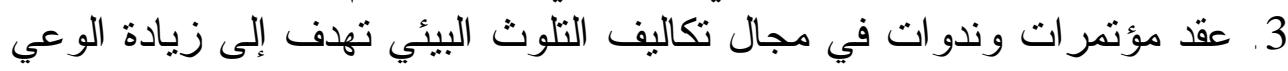
و و المعرفة بقضايا التلوث البيئي .

4. تعيين أفر اد أكفاء يحملون مؤهلات وخبا لتون الئير ات في مجالات التلوث البيئي وكيفيــة التعامل معه محاسبياً. 5. اثشتر الك الثركة ببعض المجلات و النشر ات التي تهتم بقضايا التـــوث البيئـي محاسبياً.

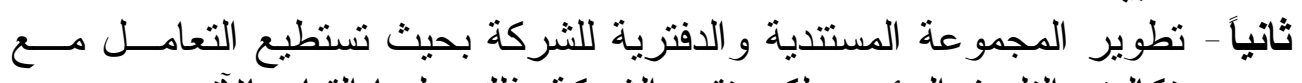
تكاليف التلوث البيئي، ولكي تقوم الثركة بذللك عليها القيام بالاتي: 
1. تحديد الانشطة و الأهداف و السياسات البيئية للشركة، ويتم ذلك من خلال إعداد

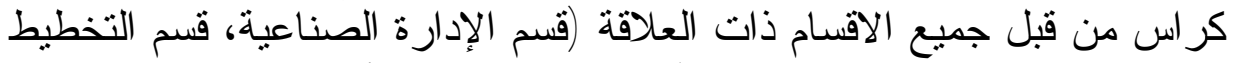

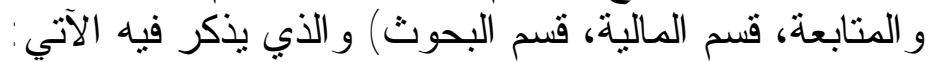

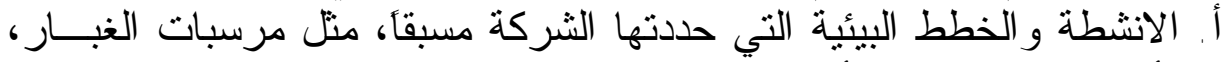

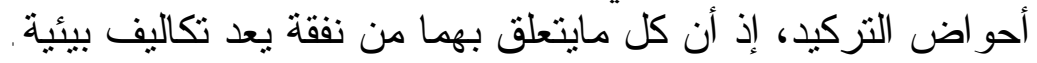

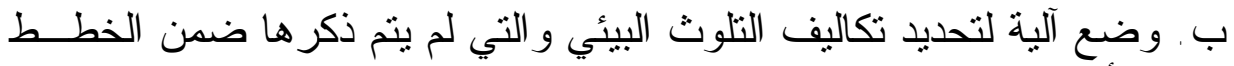

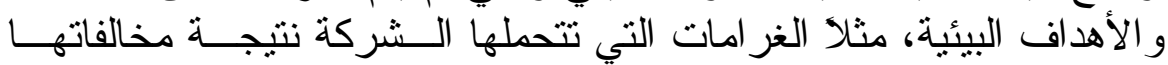

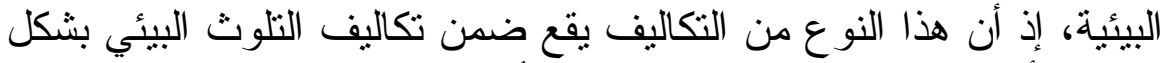

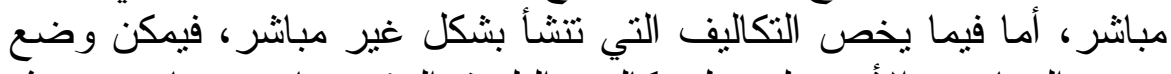

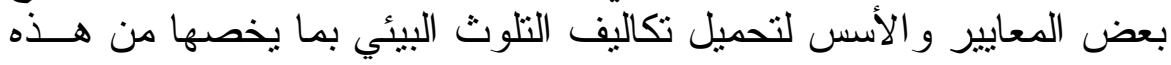
التكاليف. 2. إثبات التكاليف السابقة في مستتدات خاصة، ويخصص لهذه المـستتـات لـــون خاص بها يميز ها عن بقية المستتدات في الثركة.

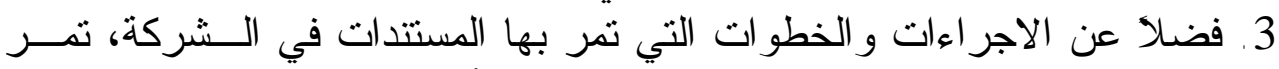
3ستتدات تكاليف التلوث البيئي إلى قسم البيئة للتأكد من صحة ما جاء التهاء بها مــن معلومات. 4. تقدير تكاليف التلوث البيئي المحتملة على وفق أسس معينة، إذ أن على الثركة

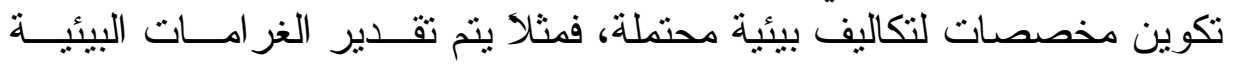

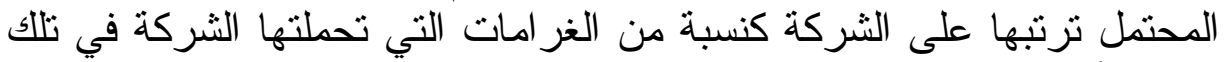

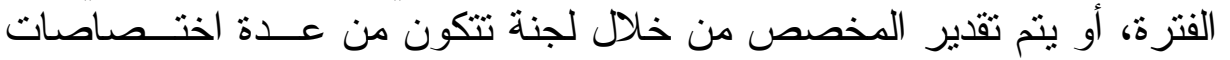

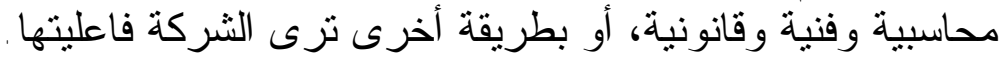

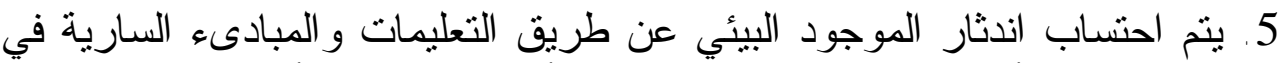

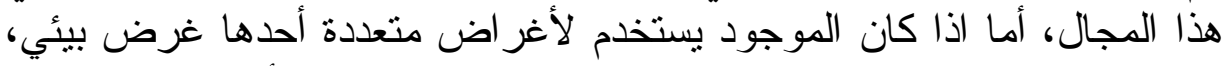

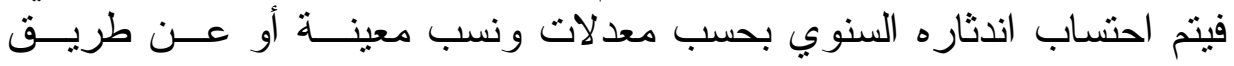
التقدير .

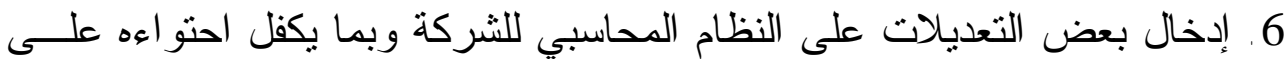

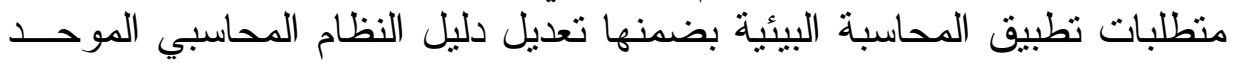
كما اقترحه الباحثنان. 7. تسجل تكاليف التلوث البيئي إما بسجلات الثركة الموجودة أصلا أو من خــانلال

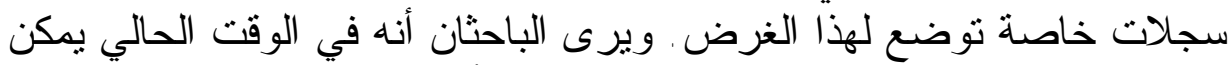

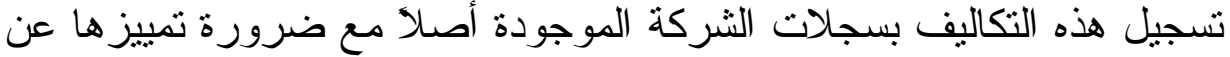

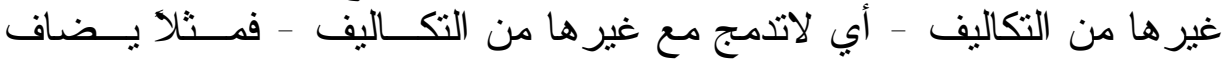

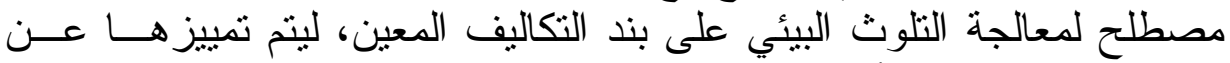

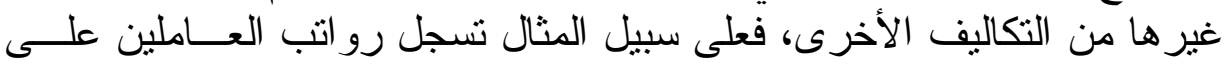


الدكتورة البكوع و الصائغ [178]

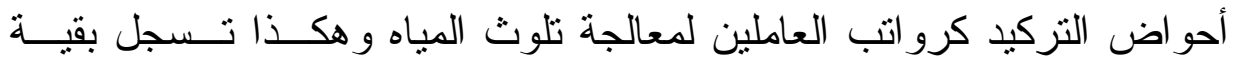

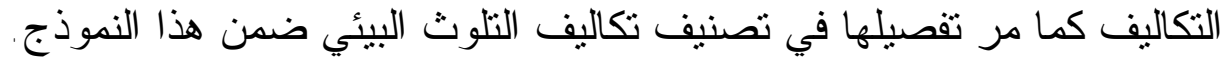

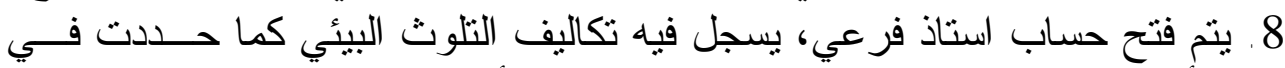

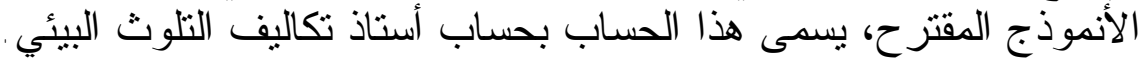

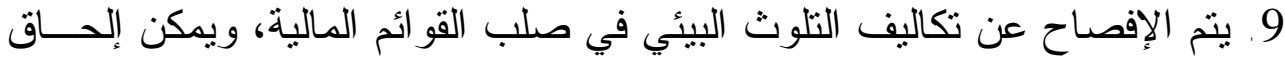

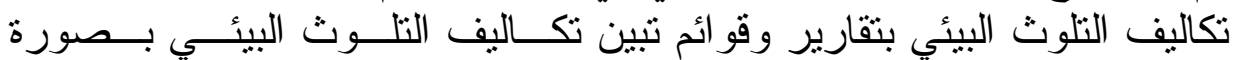
تفيلية، أما فيما يخص الاستخدامات الداخلية لتكاليف التلوث البيئي فإنه يمكن

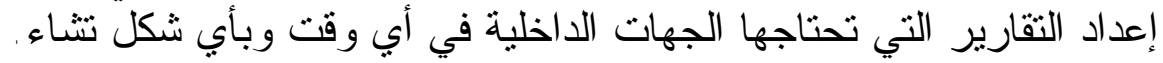
10 . اعتماد كر اس يتم فيه تتبيت المعايير ونسب النلوث البيئي المسموح بها و القو انين و التشريعات البيئية و الخطط و السياد لتهات البيئية التي اعتمدتها الثركة.

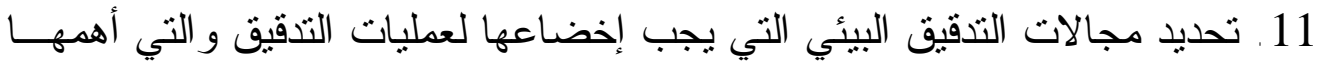

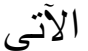
أ. التأكد من الالتز ام بالقو انين و المعايير و المقاييس البيئية الموضو عة من قبل

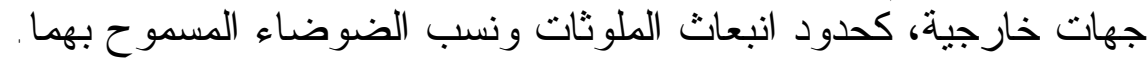

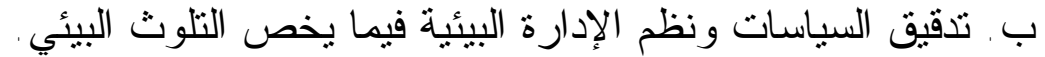
ج. تدقيق المستتدات و السجلات التي يتم تثبيث وتسجيل تكاليف التلوث البئئي فيها. د. تدقيق التقارير و القو ائم التي يتم الإفصاح عن مستويات وتكاليف التلــوث البيئي فيها.

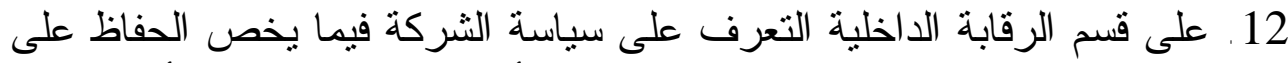
البيئية الداخلية و الخارجية بصورة كافية، إذ أن عليه الاطلاع على النى أهداف هذه

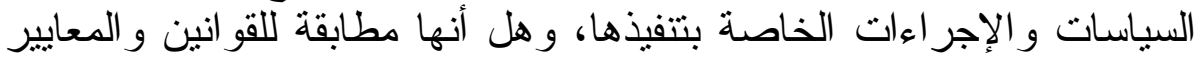
الخاصة بذلك .

13. وضع بعض المؤشر ات و المقاييس الخاصة بأداء الثركة البيئي، ووضع الآلية

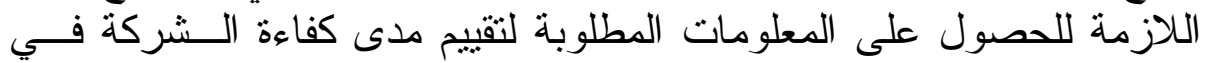
تطبيق السياسات البيئية.

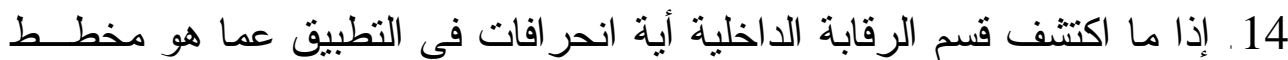

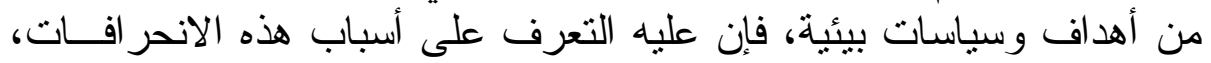
ومن ثم إيصال توصياته إلى الجهات المعنية بذلك.

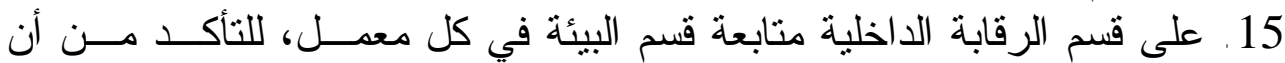

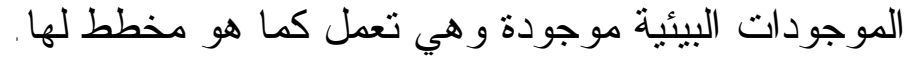

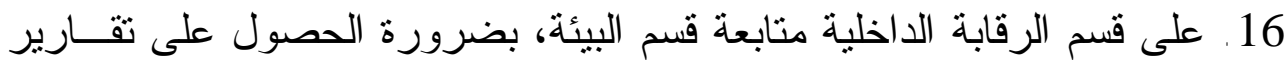

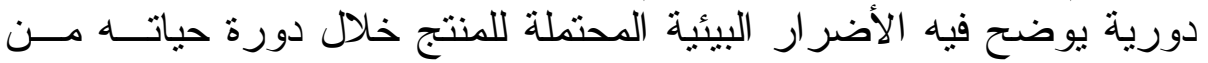

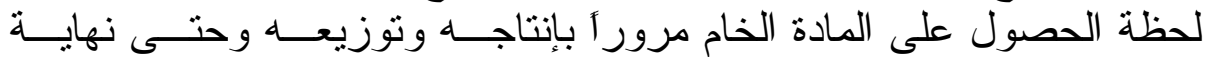




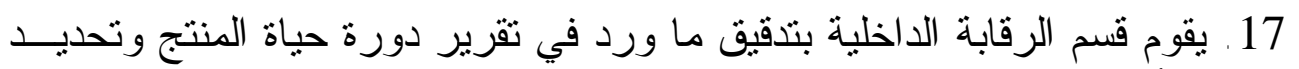

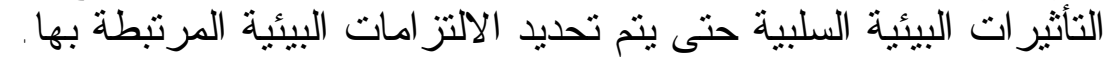

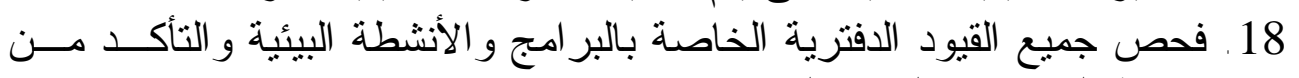
صحة المستندات المؤيدة لها. 19 ـ فحص جميع المستتدات المؤيدة للأحداث المالية وغير المالية المتعلقة بالجوانب المبات البيئية للثركة.

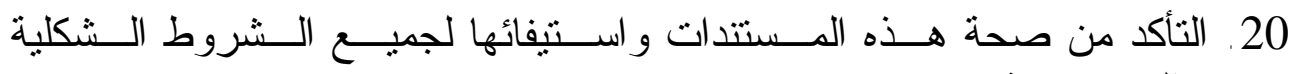
و الموضو عية.

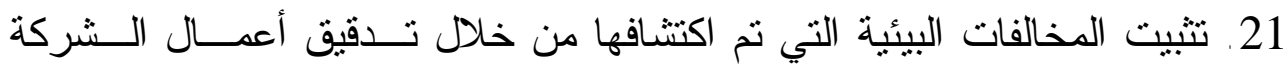

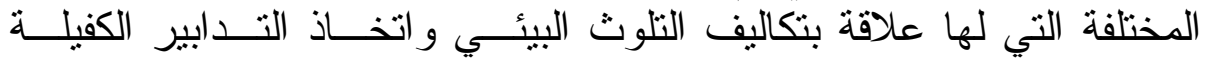
بمعالجنها. 22. متابعة الإجر اءات التصحيحية للمخالفات التي تم اكتثافها وتثبيتها مــن قبــل

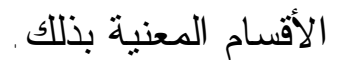

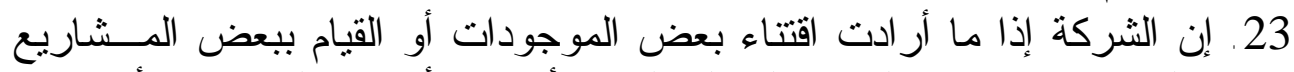

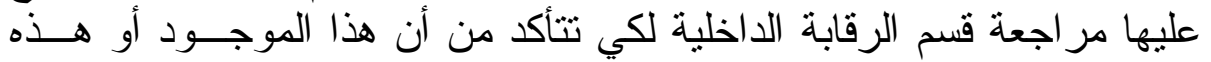

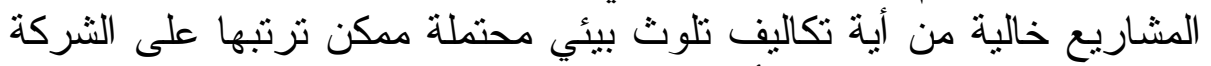

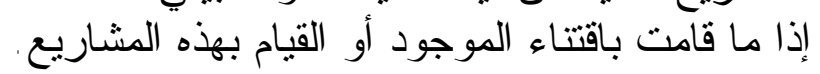

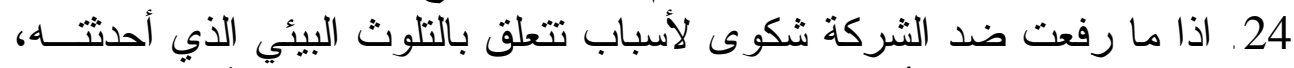

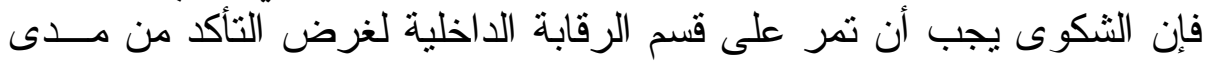

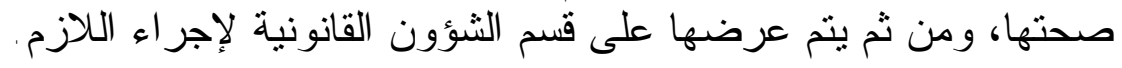

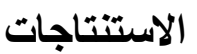

1. إن الاهتمام بالبيئة ومسائل التلوث البيئي ماز ال ضعيفاً، إذ أن هذه المواضيع تعد من الأمور الثنانوية في الثركة.

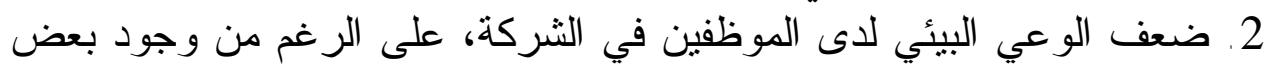

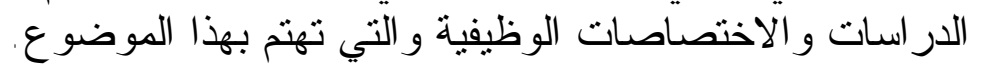

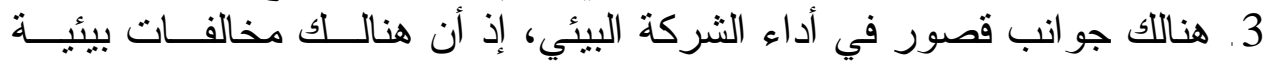

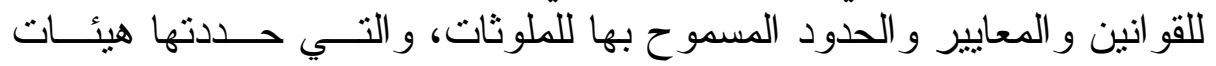

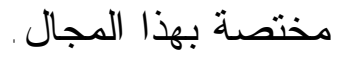
4. إن أنشطة الثركة لها نأثيرات سلبية على البيئة، إذ ينولد عن أنشطتها ملوثات

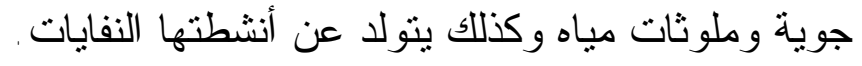

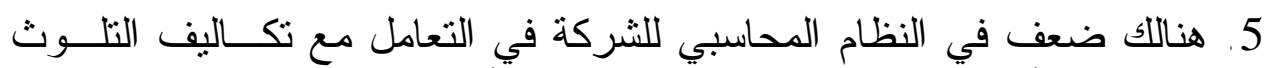
البيئي، إذ أن النظام المحاسبي فيها لا يحوي أية آلية معينة للقياس و الإفصاح 


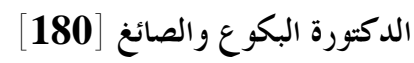

عن هذه التكاليف بشكل و اضح، إذ يتم إخفاء تكاليف النلوث البيئي، وذللك من

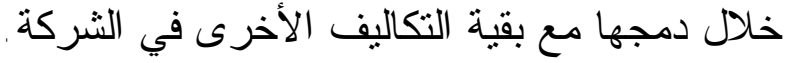

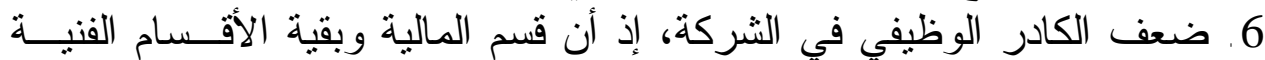

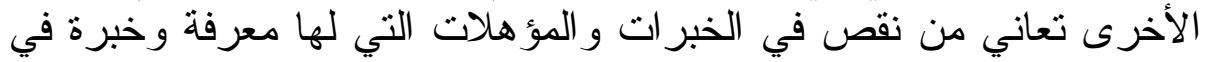
مجالات التلوث البيئي و التعامل معه محاسبياً وفنياً.

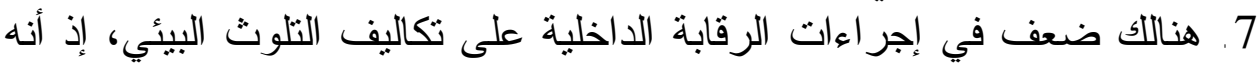

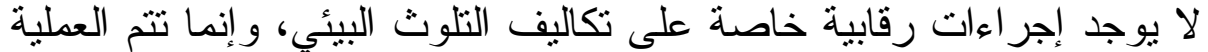

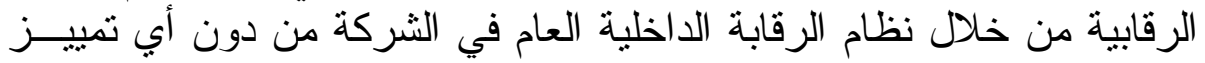
لإجر اءات الرقابة على تكاليف التلوث البيئي.

التوصيات

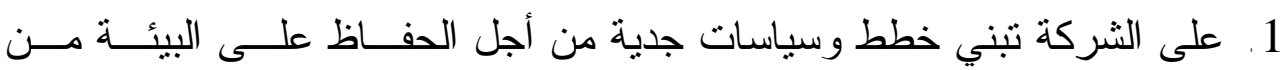

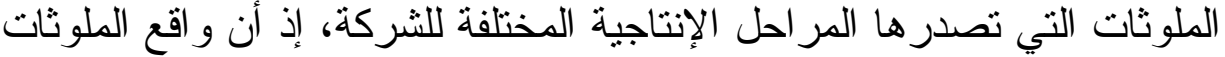

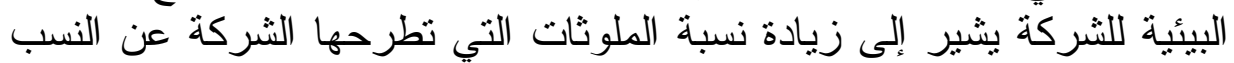
المسموح بها.

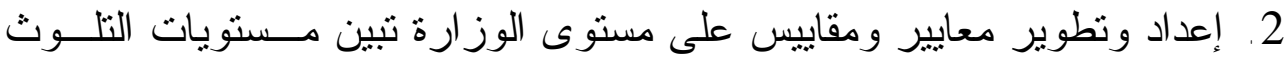

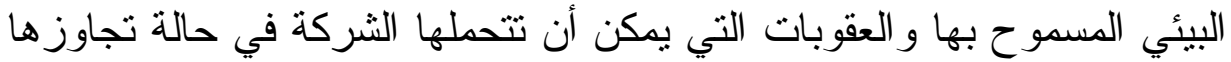
لهذه النسب المسموح بها.

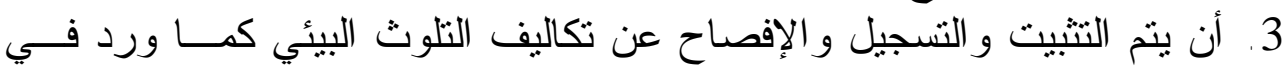

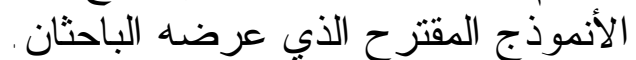

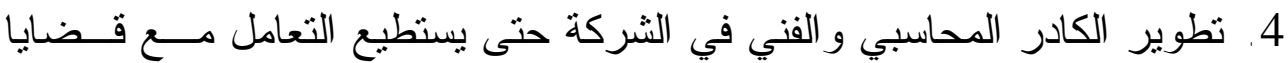

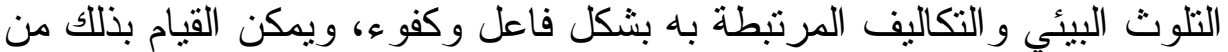

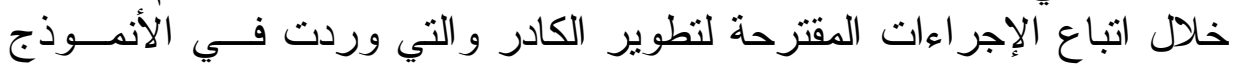

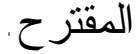
5. على ديوان الرقابة المالية و الجهات المختصة الأخرى بقضايا التلـــوث البيئيسي

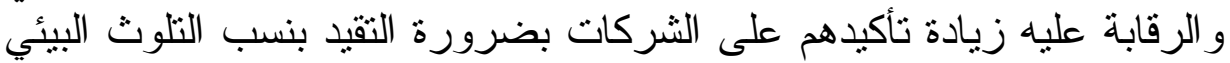

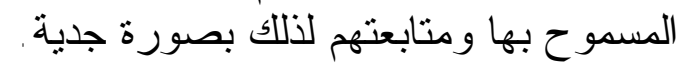

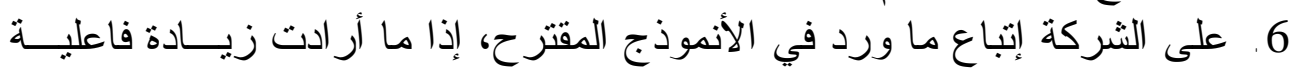
نظام الرقابة الداخلية فيها.

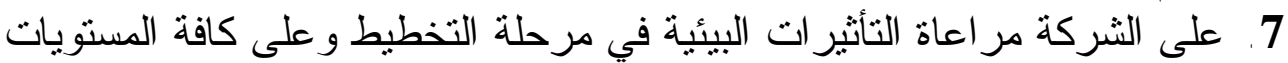

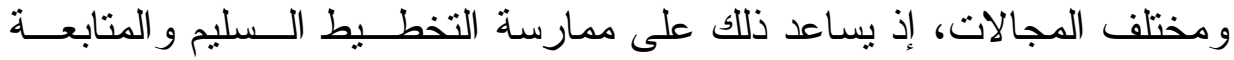

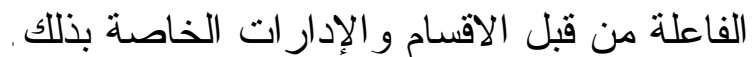




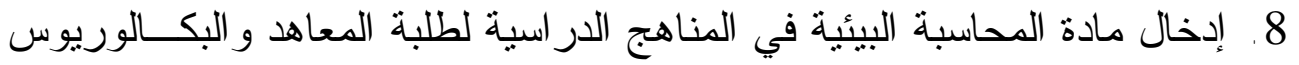

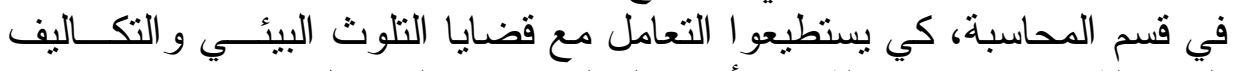

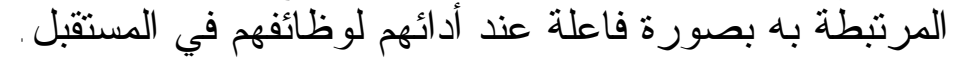

\section{المر اجع

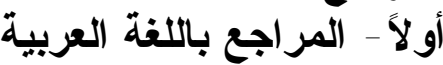

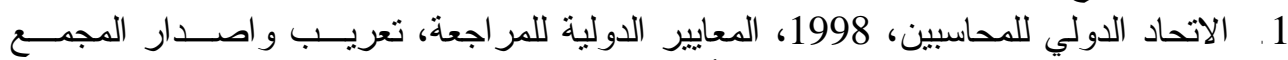

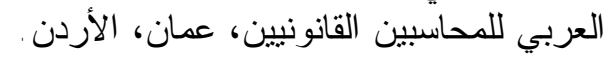

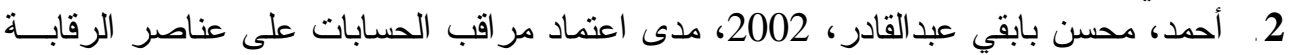

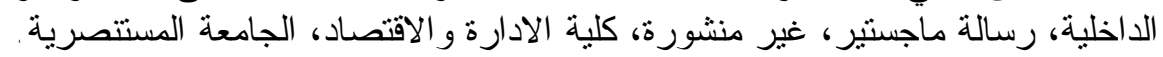

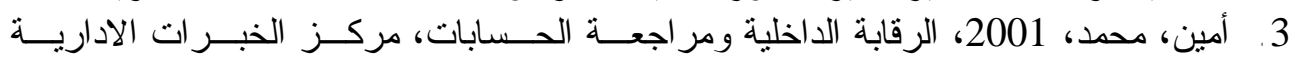

و المحاسبية.

4. الانتوساي، 2001، توجيهات بخصوص تلتفيذ العمليات الرقابية على النشاطات ذات المنظور

البيئي، مجمو عة عمل للرقابة البيئية.

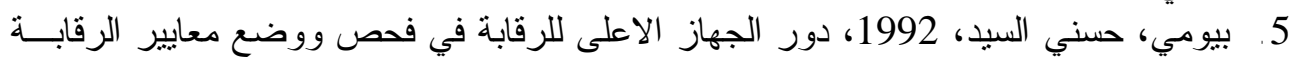

الداخلية، مجلة الرقابة المالية، نونس، العند، دون العدد 2.

6. جععة، احمد حلمي، 2000، الدذخل الحديث لتدقيق الحسابات، الطبعة الاولى، دار صــفاء

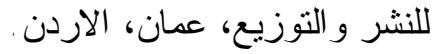

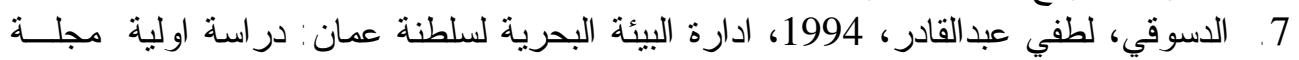

الاداري، العدد الطمي، 59.

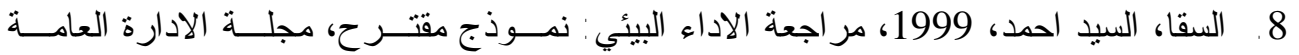

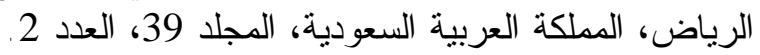

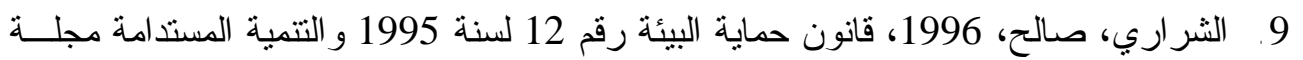

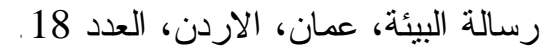

10. عبد السلام، كمال عبد السلام، 1999، الماردة الماسبة البيئية احد المتطلبات الاساسية للمر اجعـة،

مجلة الرقابة المالية، تونس، العدد 35.

\section{ثانياً - المر اجع باللغة الاجنبية}

1. John Wiley \& Sons, 1998, Practical Pollution Prevention Activity-Based Costing For EHS, Pollution Prevention Review .

2. Randal J. Elder, Mark S. Beasley, 2000, Auditing An Integrated Approach, United States Of American, New Jersy .

3. Whittington, O. Ray, Pany, Kurt, 1998, Principles Of Auditing 12th edition, Mccraw-Hill Calnc, New York .

www.epa.gov/sbo/auditbook 500.pdf . 
ص ص21-9]

$$
\begin{aligned}
& \text { محدداث تدفقاث رأس المال الخاص } \\
& \text { في عدد من دول شرق أسيا }
\end{aligned}
$$

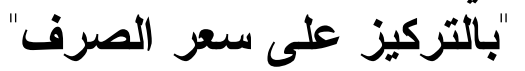

$$
\begin{aligned}
& \text { الدكتور سعدون حسين فرحان } \\
& \text { مدرس-قسم الاقتصاد } \\
& \text { كلية الادارة والاقتصاد-جامعة الموصل }
\end{aligned}
$$

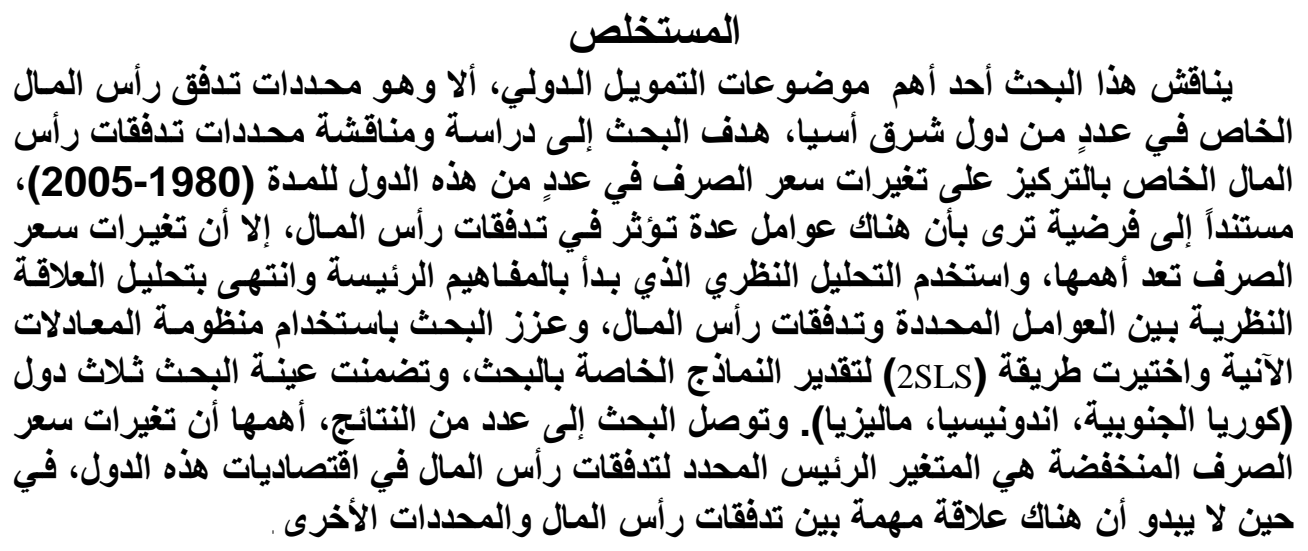

\title{
Determinants of Private Capital Flows in a Number of East Asian Countries with Special Reference to Exchange Rate
}

\author{
Sadoon Husieen Farhan (PhD) \\ Department of Business Administration \\ University of Mosul \\ Saadoonhuseen@yahoo.com
}

\begin{abstract}
This research discusses one of the most important subjects of international finance, the determinants of private capital flows in a number of East Asian Countries. The research aimed at studying and discussing the determinants of the Private Capital's Flows through focusing on the variations of Exchange Rate in several East Asian Countries for the period (1980 - 2005). It is hypothesized that there are many factors affecting the capital flows, and
\end{abstract}


the changes of Exchanges Rate are the most important among them. The research used the theoretical analysis started by the main concepts and ended with the analysis of the theoretical relationship between the determinant factors of the capital flows. The research is enhanced by using a set of instantaneous equations, (2SLS) method is selected to estimate the models of the research. The sample of this research involved three countries (South Korea, Indonesia and Malaysia). The research concluded some results; the most important is that the low variation in Exchanges rate is the main variable which determines the capital flows in the economies of these countries, while it is not seem that there is a significant relationship between Capital's Flow and the other determinants.

المقدمة

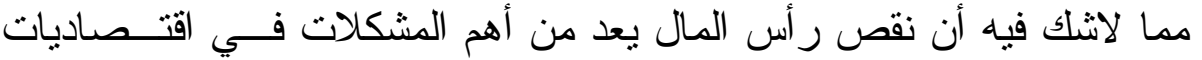

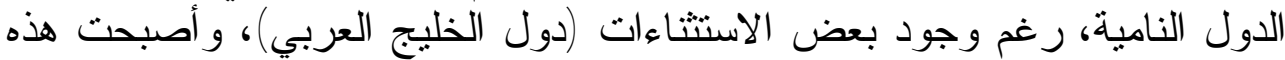

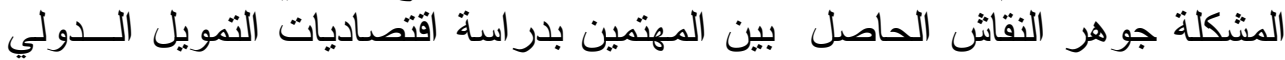
سو اء كانو ا باحثين أم هيئات ومنظمات دولية (صندوق النقا و البنك الدوليين)، وقدات

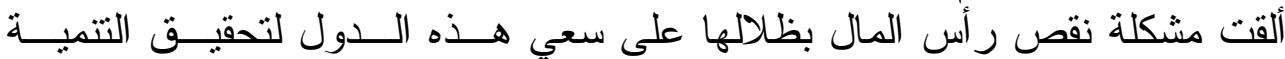

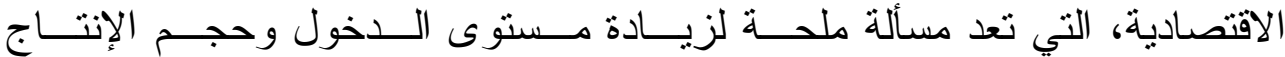

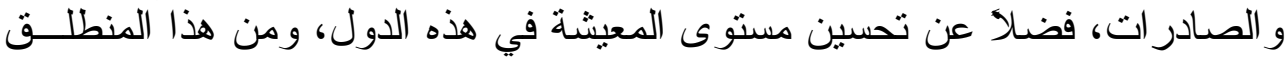

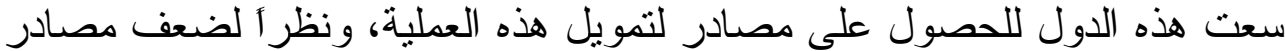

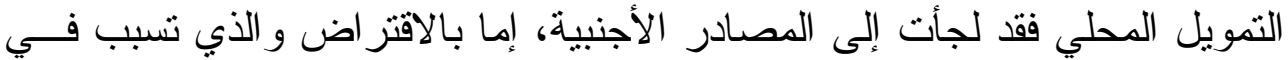

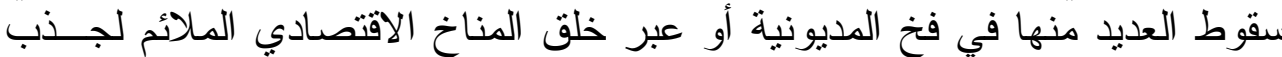

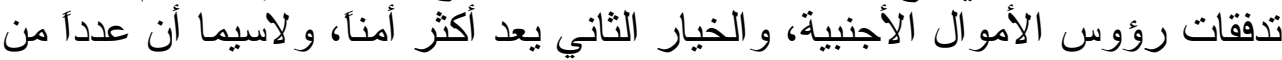

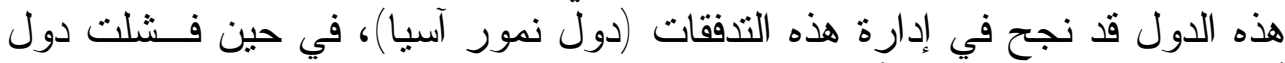

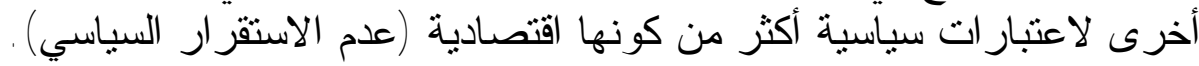

تعد در اسة محددات تدفقات رأس المال الخاص (بالتحديد ســعر الــصرف) أهمية البحث

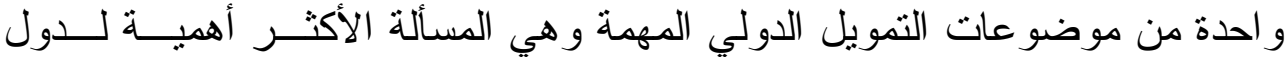

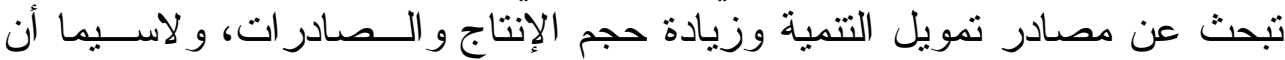

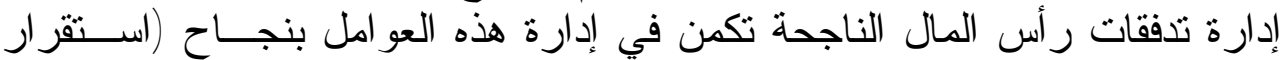

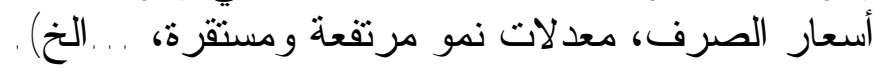

تتلخص مشكلة البحث في أن السير بعملية التتمية في العديد من الدول النامية

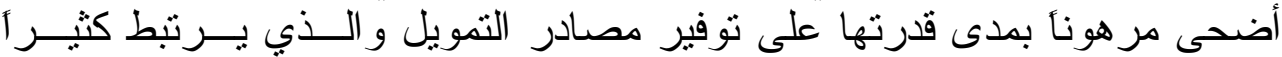

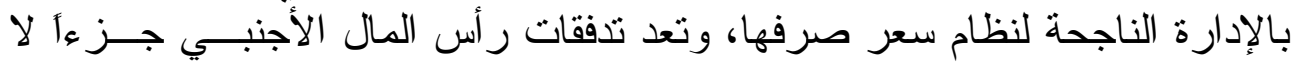
يتجز أ من هذه المصادر ، شرط أن تهدف إلى الاستثمار وليس إلى المضارئارية. 
يهدف البحث إلى دراسة وتحليل العوامل المؤثزة في تــدفقات رأس المــال

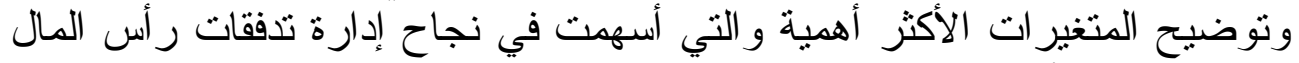
في دول شرق آسيا استتادأ إلى التحليل النظري و التجريبي.

فرضية البحث

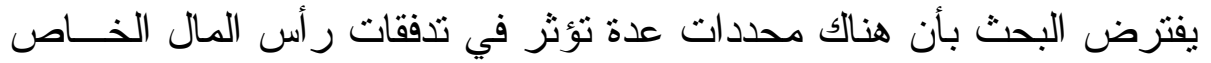
في دول شرق أسيا، إلا أن سعر الصرف يعد أهم هذه المحددات في هذه الدول.

ربط البحث بين جانبين، الأول: الإطار النظري الذي ابتدأ بالمفاهيم الأساسية

\section{منهج البحث}

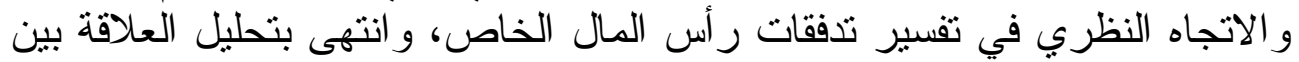

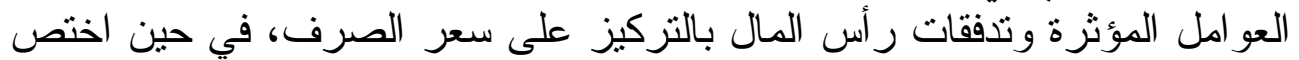

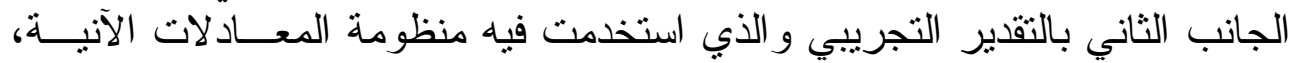

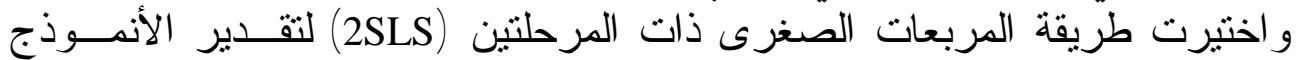

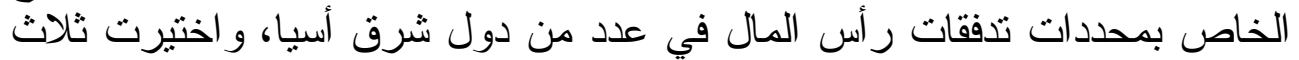

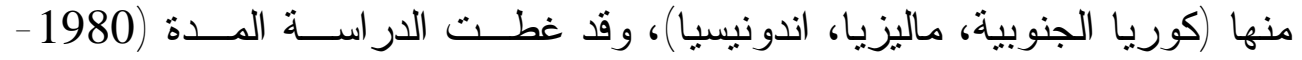
. (2005

الأسس النظريسـة لار اســـة تدفقات رأس المــال الخاص في دول شرق آسيا أولاً - مفهوم تدفقات رأس المال

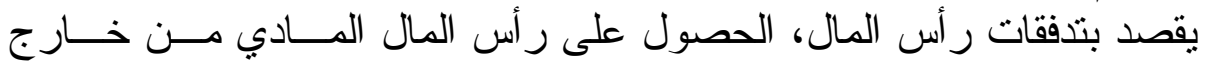

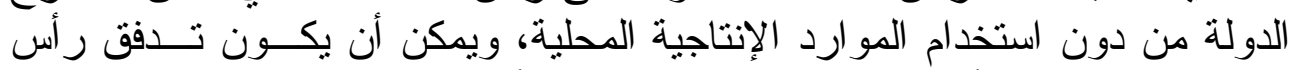

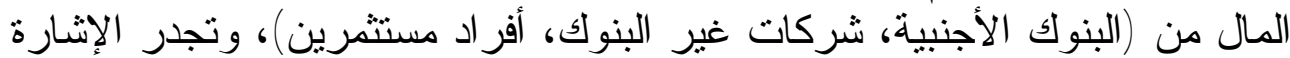

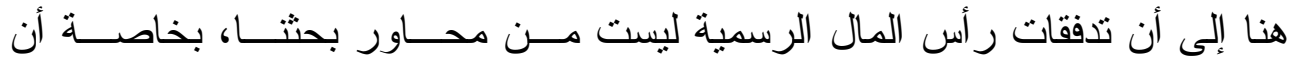

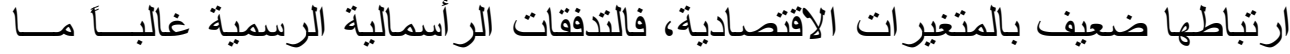

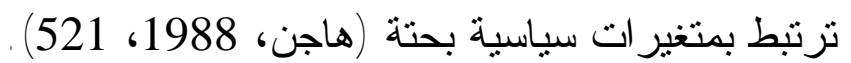
ثنانياً - أشكال تدفقات رأس المال الخاص تتخذ تدفقات رأس المال الخاص ثلاثة أثنكال رئيسة وهي بالثنكل الآتي:

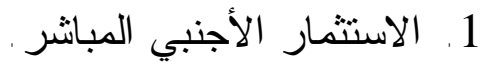

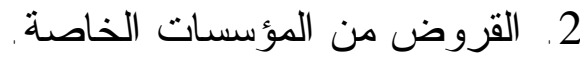
3. تدفقات رأس المال لأغر اض المضات الفاربة (تدفقات المدى القريب).

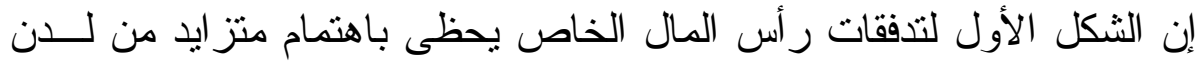

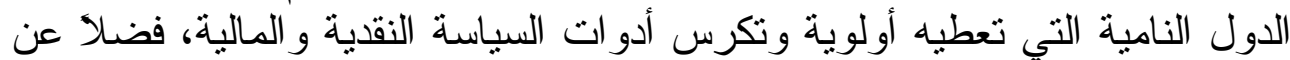

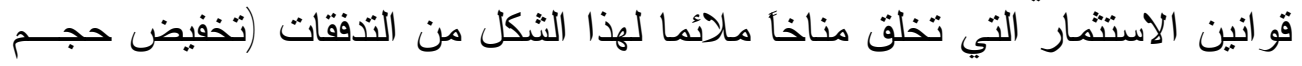




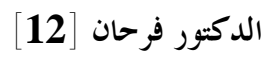

الضر ائب، رفع بعض الرسوم التي تعيق تدفق الاستثمار الأجنبي... و غير ها مـنـ

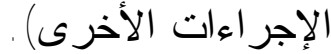

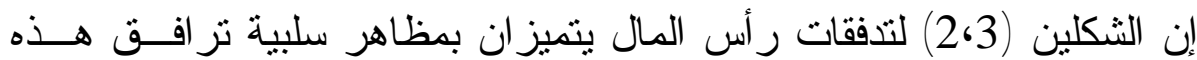

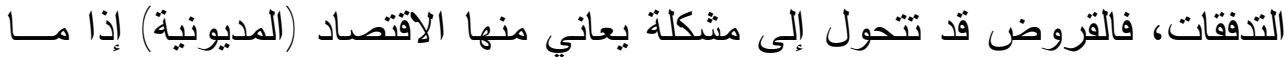

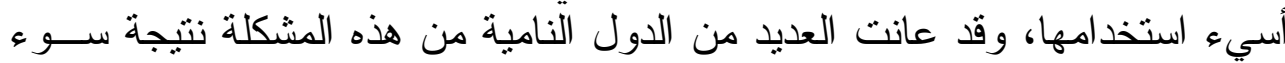

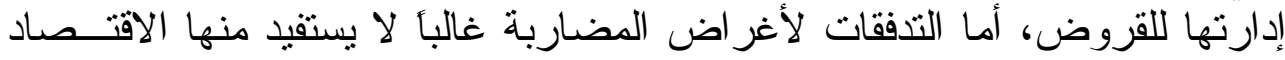

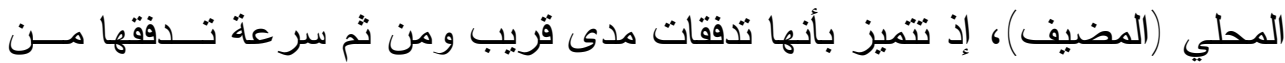

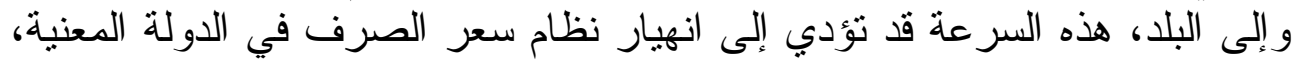

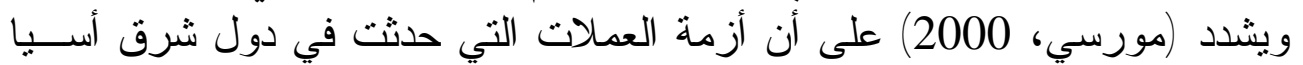

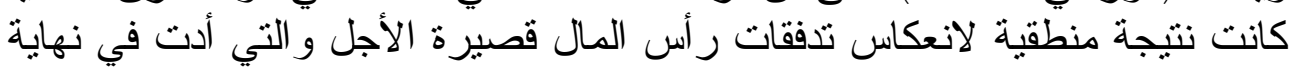

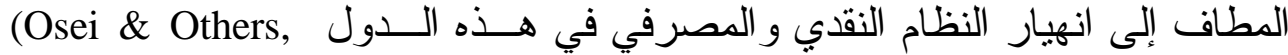
.2002, 1-4)

ثالثاً - نظرية تدفقات رأس المال الخاص (دوافع تدفق رأس المال)

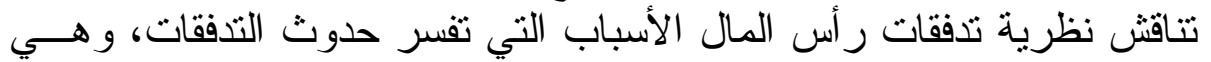

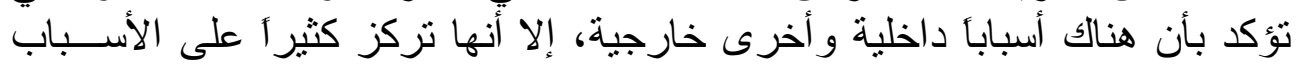

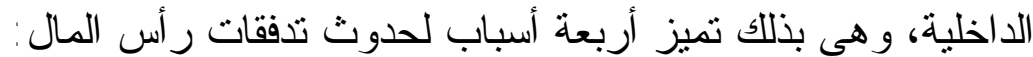

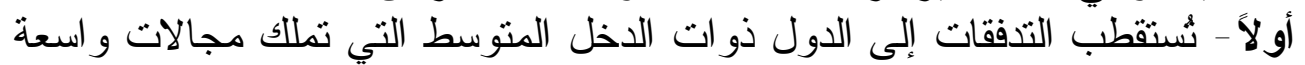

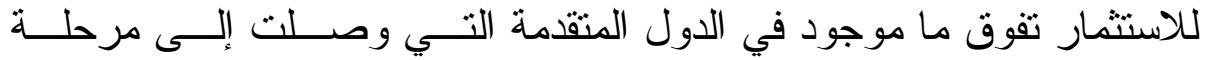

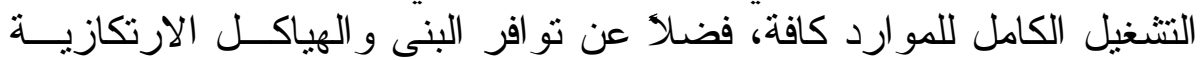
بخلاف الدول منخفضة الاخل التي تشكو من نقص كبير فيها.

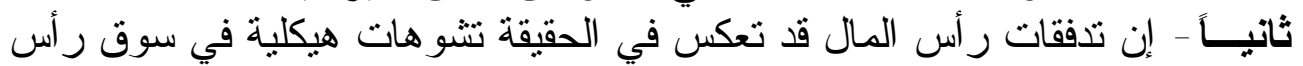

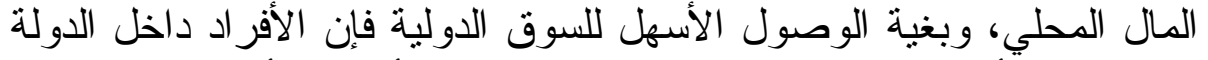

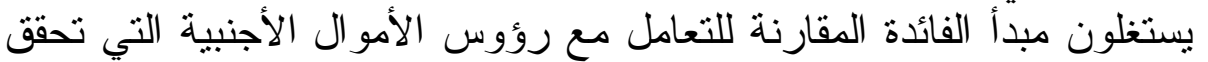

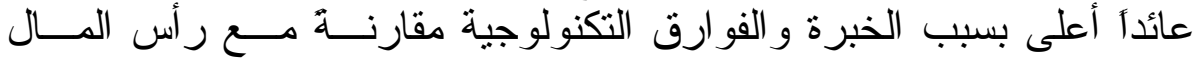
المحلي.

ثالثاً - قد لا تكفي مصادر التمويل المحلي لتغطية تكاليف التتمية الاقتصادية لــذلك فئل

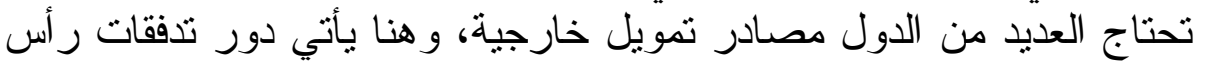

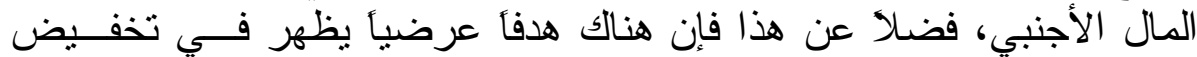

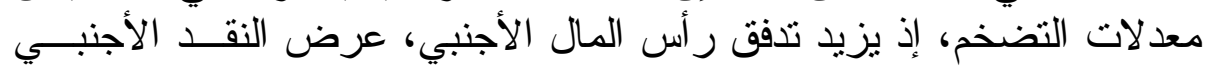
ومن ثم يزداد عرض النقد الحقيقي المحلي، وهذا يزيد من قيمة العملة العلة المحلية

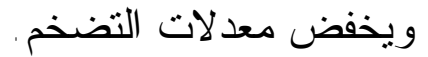

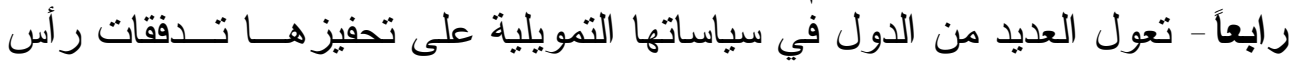

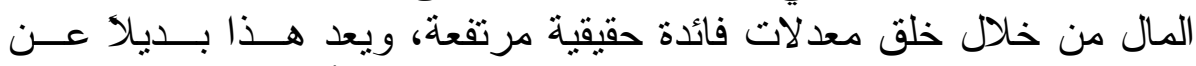

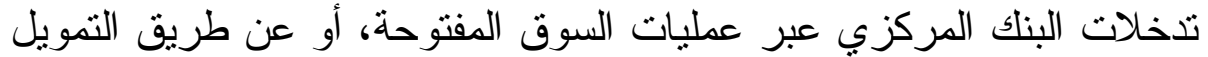

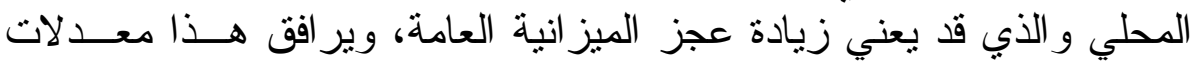




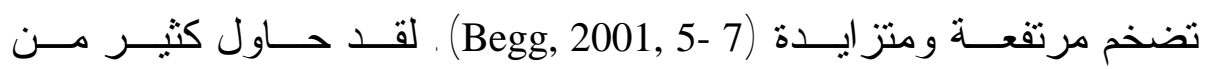

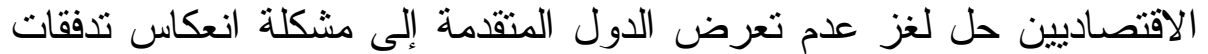

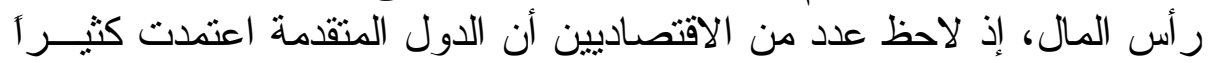

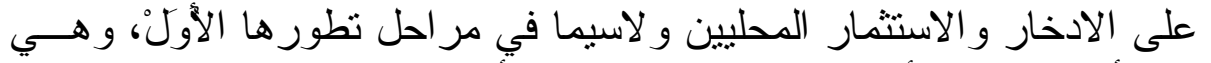

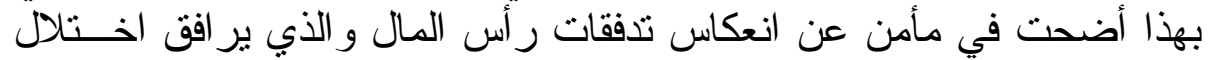

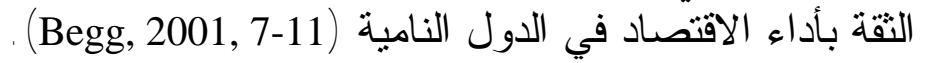

الاتجاهات التأثيرية للعو امل المحددة في تدفقات رأس المال الخاص التاص

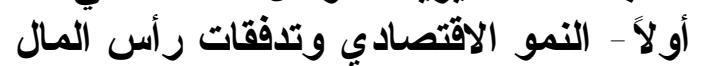

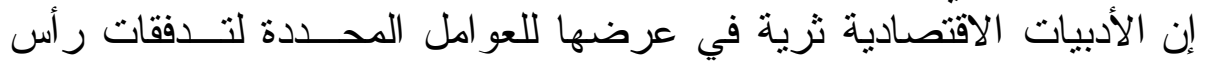

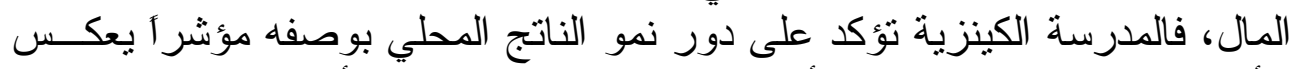

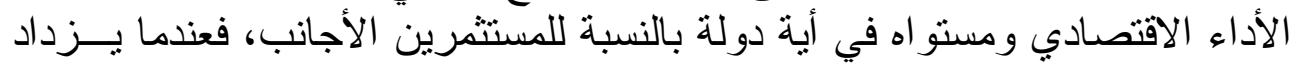

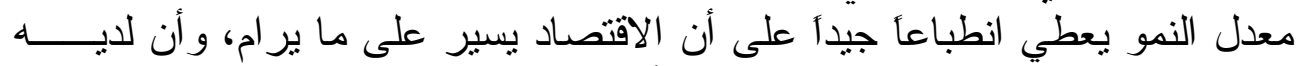

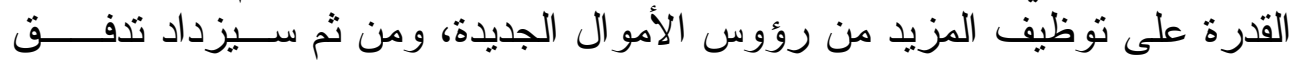

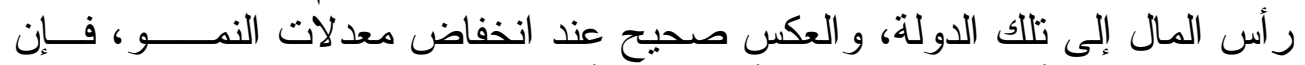

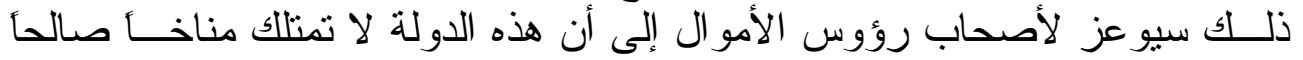

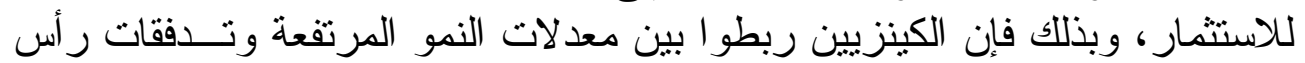

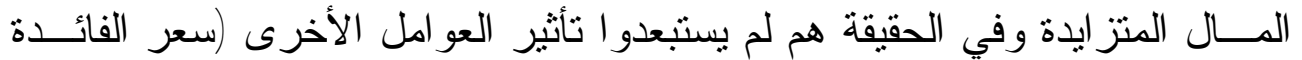

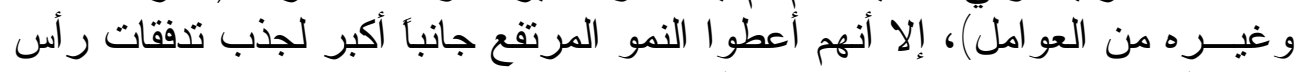

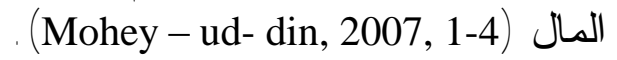

ثانياً - سعر الفائدة وتدفقات رأس المال الخاص

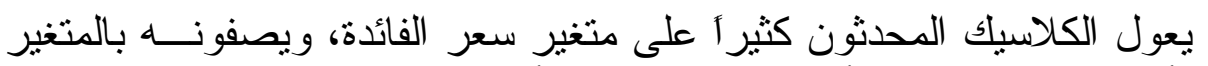

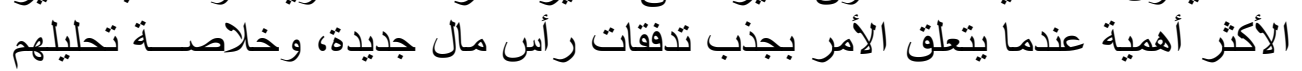

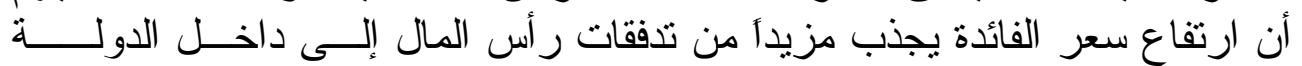

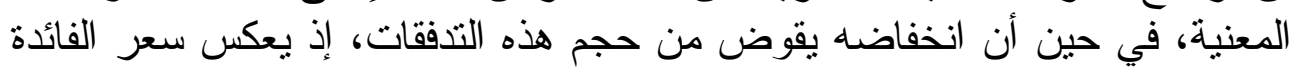

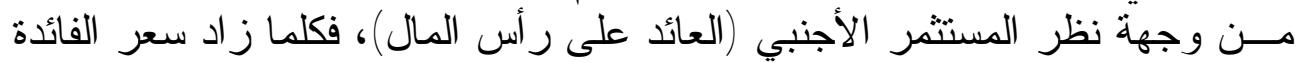

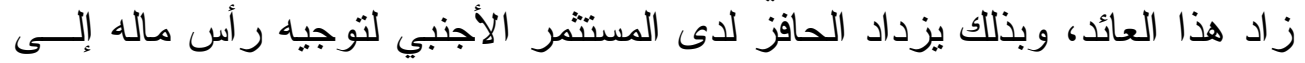
هذه الدولة (عبد العظيم، 2002، 7 -3 -3).

ثالثاً - تغيرات سعر الصرف وتدققات رأس المال

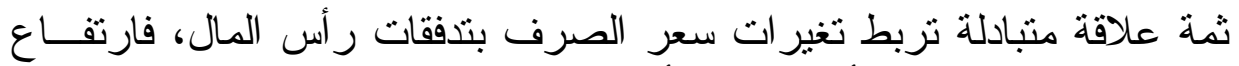

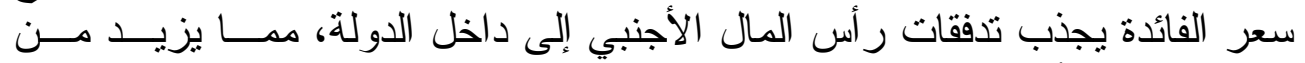

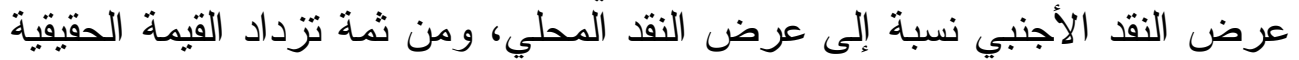

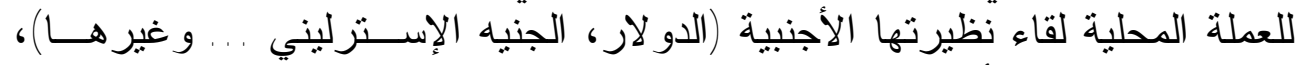

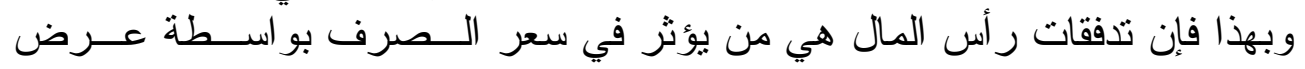




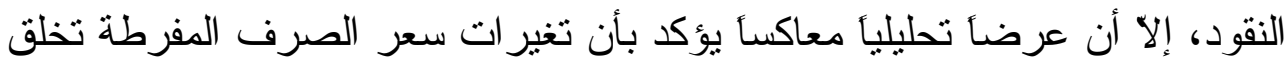

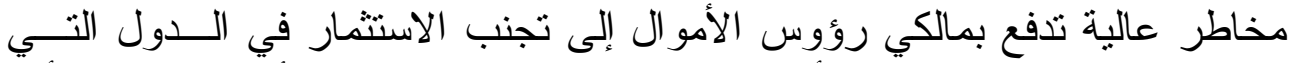

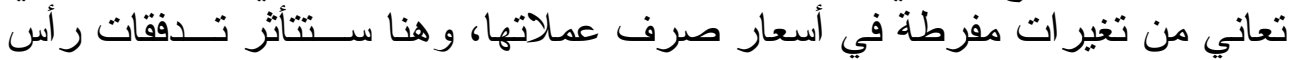

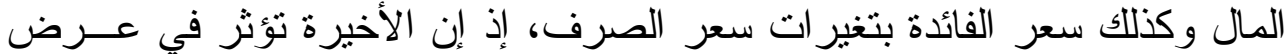

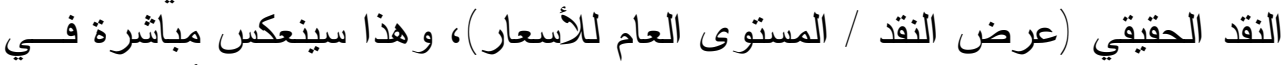

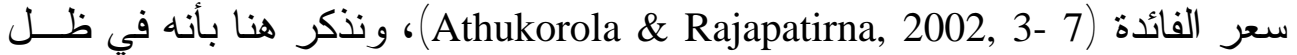

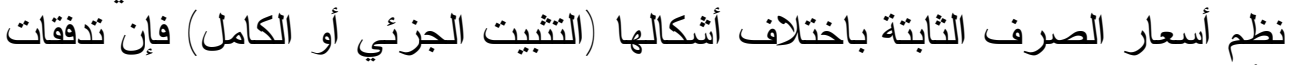

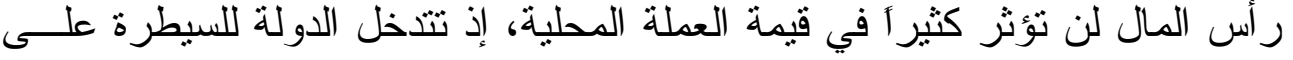

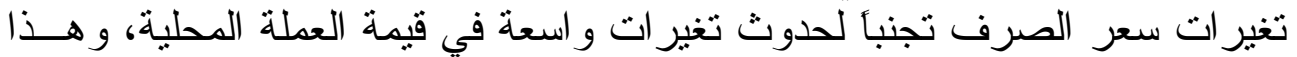

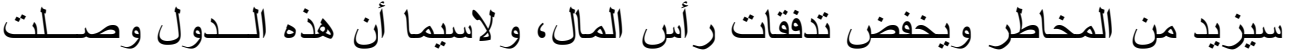

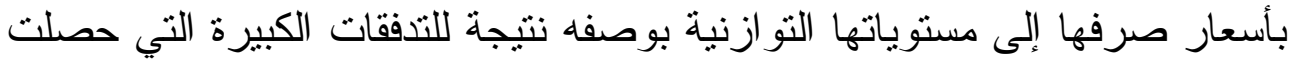
عليها في مر احل تطور ها الأول . لئل

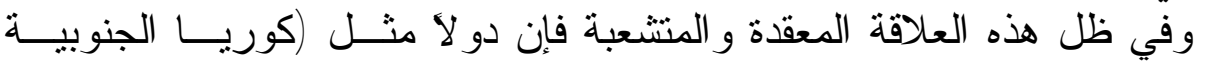

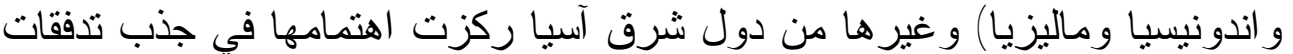

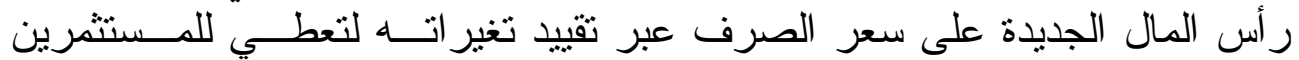

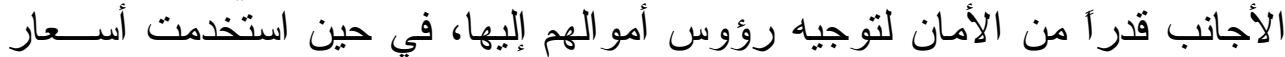

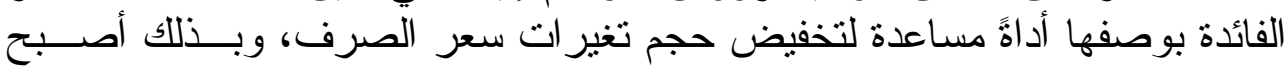

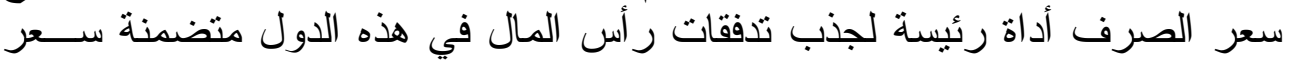

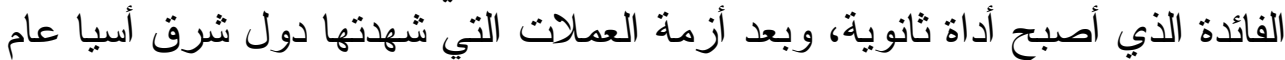

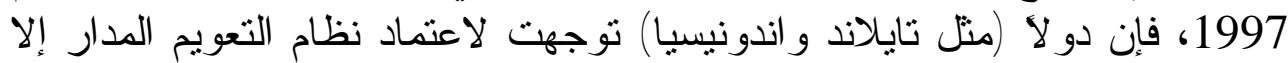

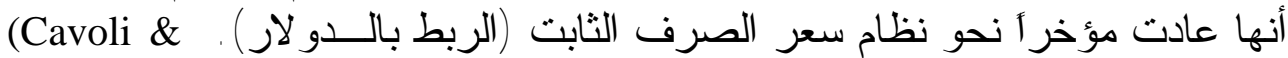

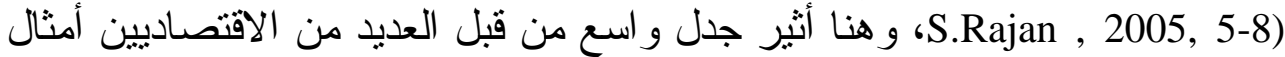

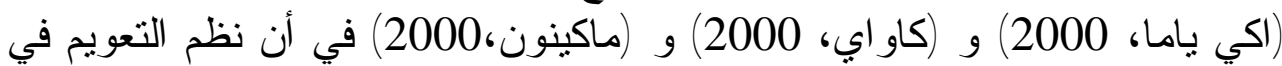

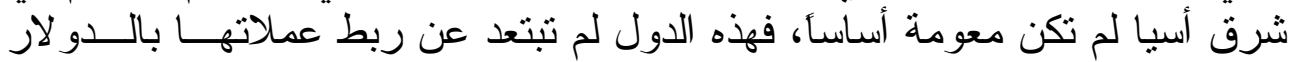
حتى بعد أزمة العملات عام (1997) (Fukuda, 2004, 71-75).

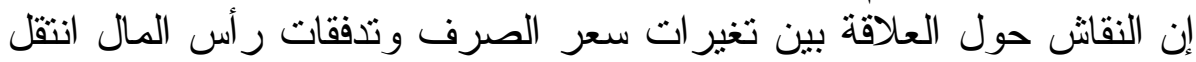

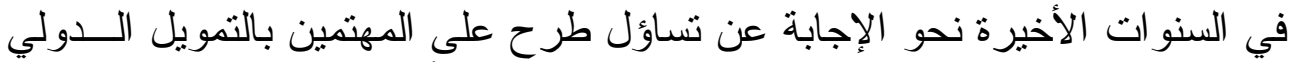

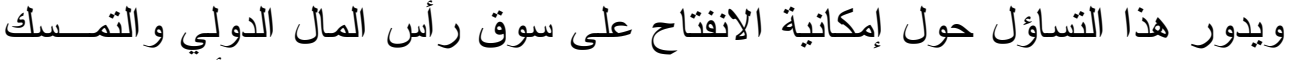

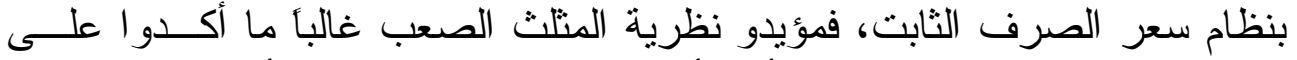

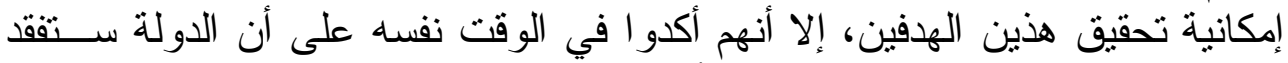

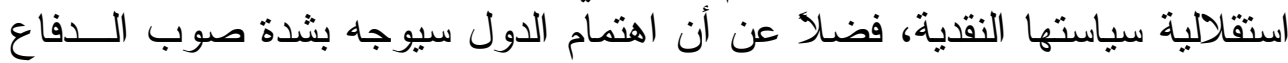
عن المثنتات (Joshi, 2003, 2-4)، إن أزمة العملات في شرق النيات أسيا كثفت استحالة

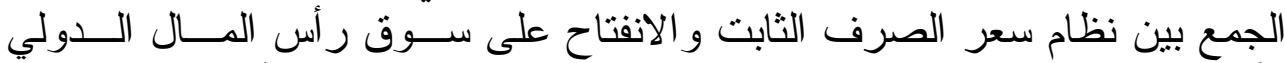

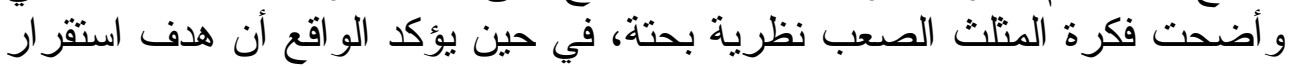

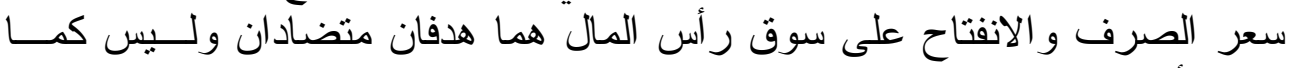
يدعي أنصار نظرية المتلث الصعب بإمكانية تحقيقهما معأ. 


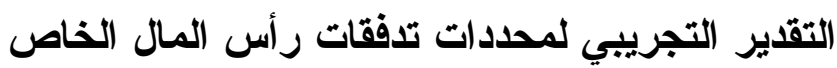

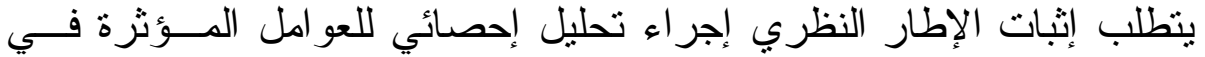
تدفقات ر أس المال، وقد وصف الأنموذج والجراء اختيرت متغير اته اعتماداً على النظرية

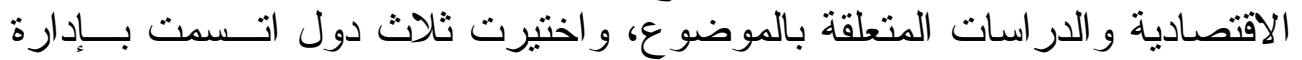

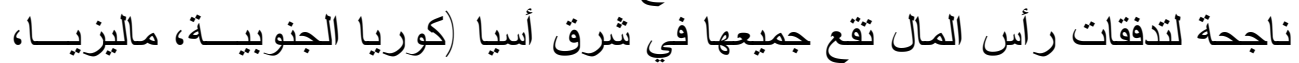

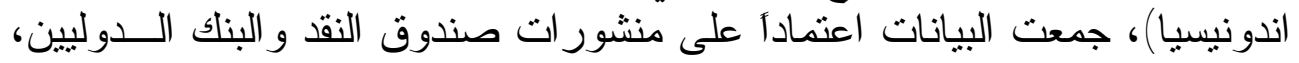
فضلا عن تقرير الاستثمار العالمي للعام 2006 الذي تصدرهات التهاد الاونكتاد .

أولاً - توصيف الأنموذج الإحصائي

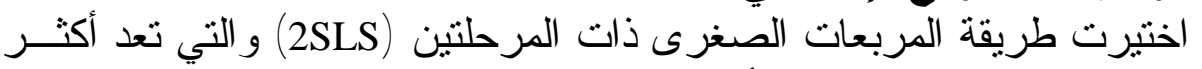
انسجاماً مع در استتا وقد وصف الأنموذج الإحصائي بالثكل الآتي: $\mathrm{EX}_{\mathrm{t}}=\mathrm{a}_{0}+\mathrm{b}_{1} \mathrm{G}+\mathrm{b}_{2} \mathrm{M}_{\mathrm{t}}+\mathrm{b}_{3} \mathrm{Cap}+\mathrm{e}_{\mathrm{i}}$

$\mathrm{Cap}=\mathrm{a}_{0}+\mathrm{b}_{1} \mathrm{gr}+\mathrm{b}_{2} \mathrm{r}+\mathrm{b}_{3} \mathrm{EX}_{\mathrm{t}}+\mathrm{e}_{\mathrm{i}}$

حيث ان:

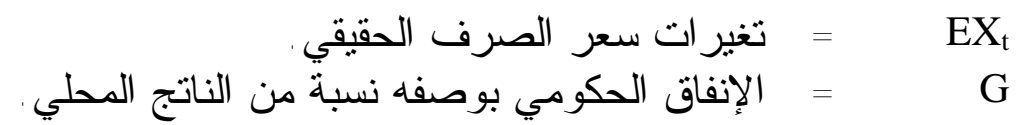

= عرض النقود بوصفه نسبة من الناتج المحلي.

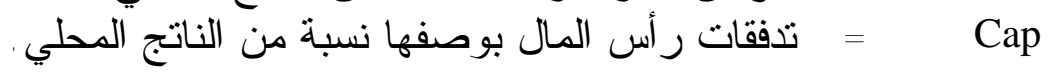

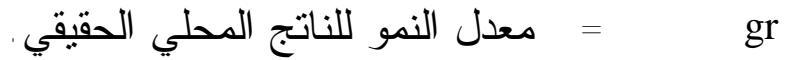
= r

= تغير ات سعر الصرف الحقيقي التي قدرت بالمرحلة 1 = EX = $=\left(b_{1}-b_{3}\right)$

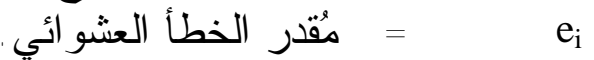
ثانياً - تفسير النتائج الخاصة بكورياً الجنوبية

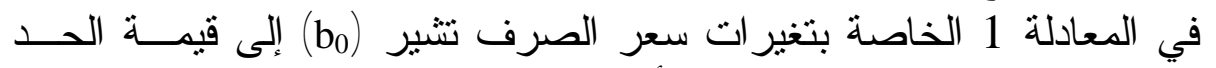

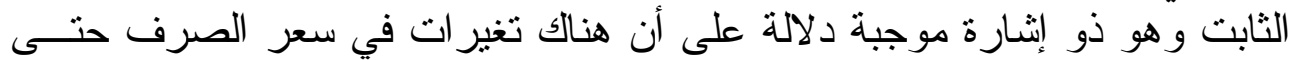

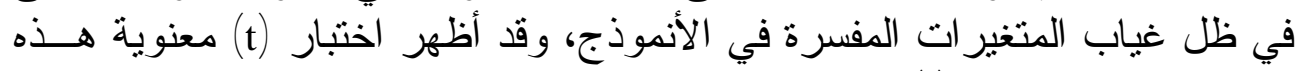

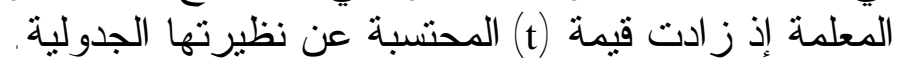

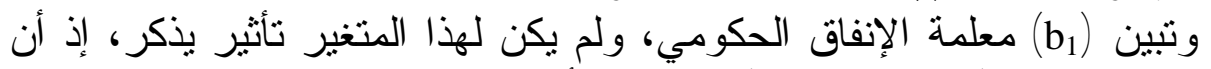

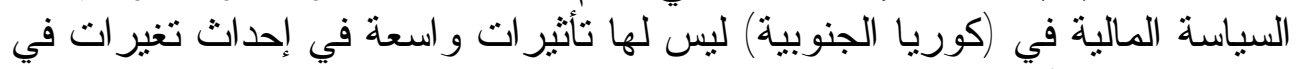

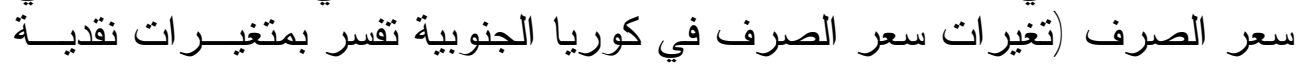

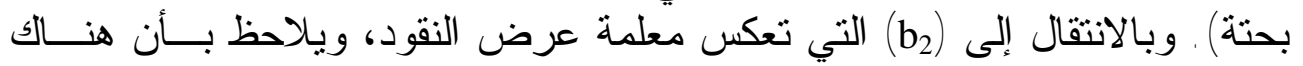
تأثير ات ايجابية ومعنوية لعرض النقان النقود في تغير ات سعر الصرف، وقد بلغنت قيمة 


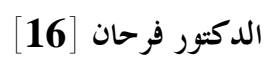

هذه المعلمة (0.77)، أي إن زيادة عرض النقود بنسبة (17\%) ثُحدِث تغيرات فـي

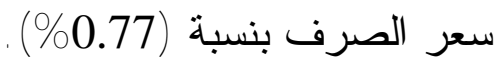
وتبين (b3) معلمة تدفقات رأس المال، ولم يكن لهذا المتغير أهمية تذكر، أي لهي

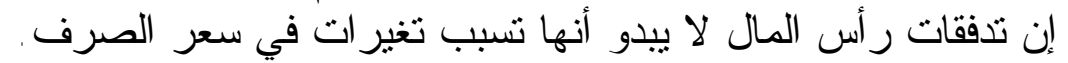

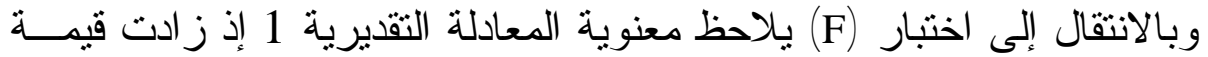

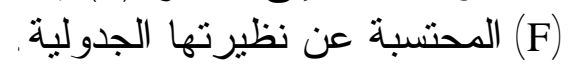

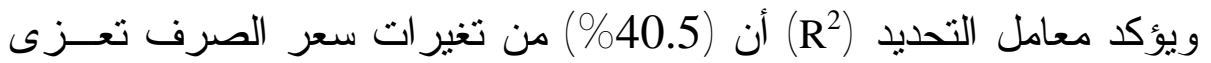

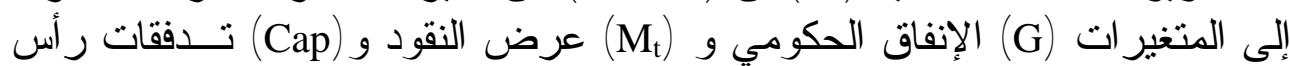

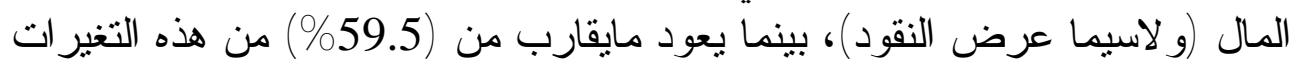

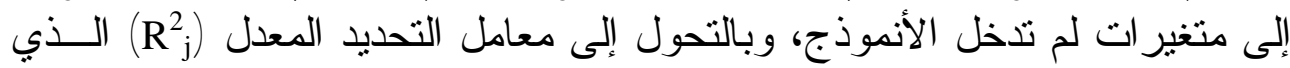

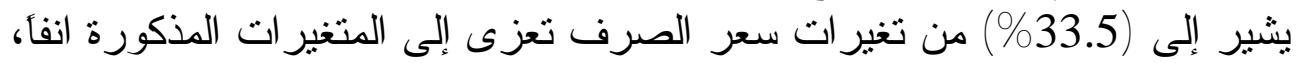
في حين تعزى (66.5\%) إلى متغير ات ات لم تدخل الأنموذج.

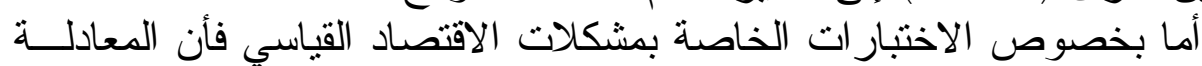

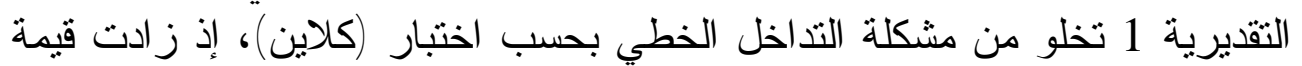
معامل الارتباط الكلي (R) عن معاملات الأرتباط الجزئي.

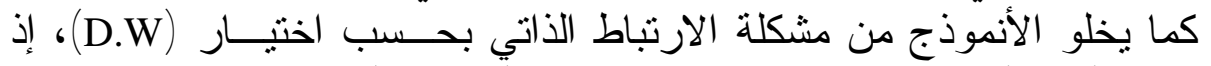
وقعت قيمة (D.W) في منطقة قبول فرضية العدم (H) وجود هذه المشكلة.

وبالانتقال إلى المعادلة التقديرية الثانية:

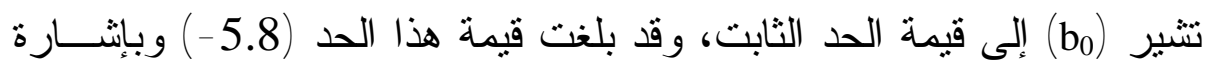

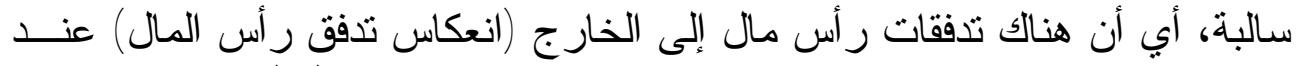

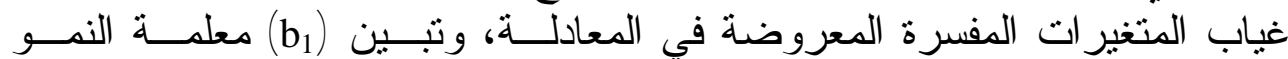

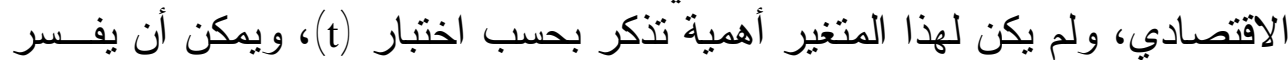

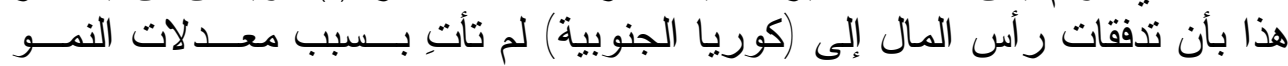

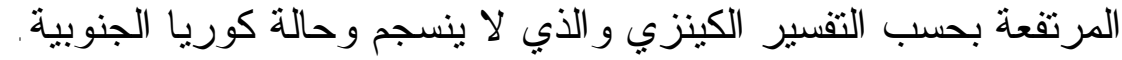

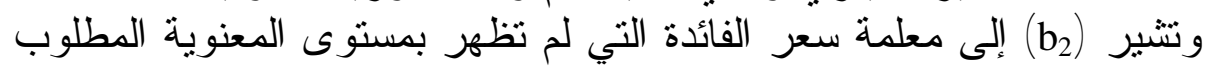

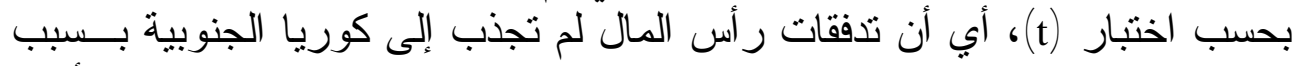

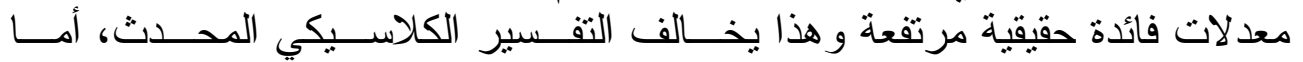

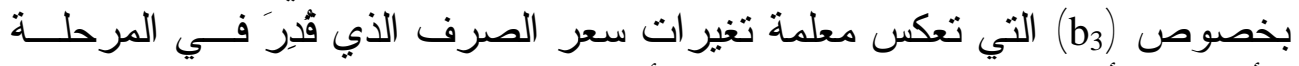

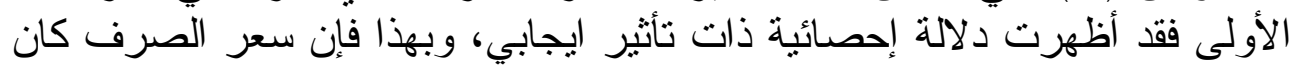

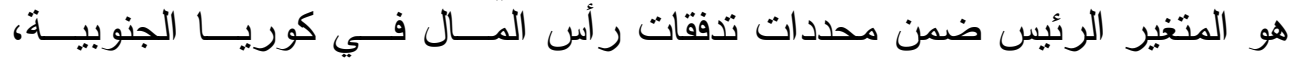

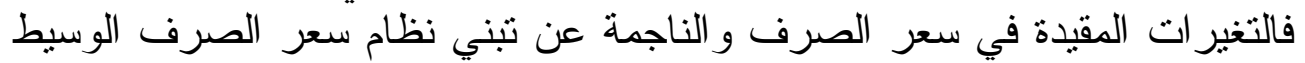

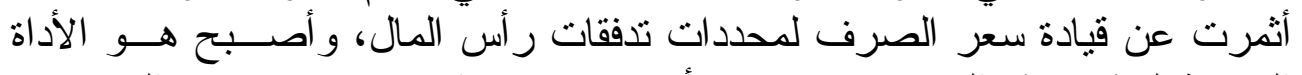

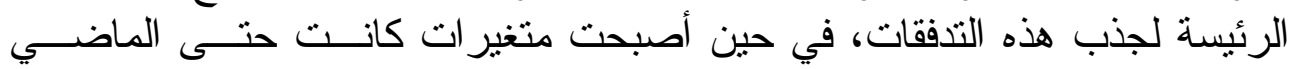


القريب تعد نواة هذه المحددات (سعر الفائدة) متغير ات مساعدة لسعر الصرف فـي

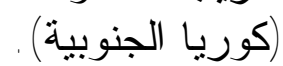

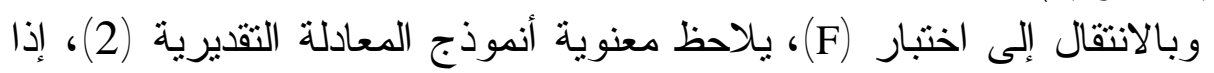

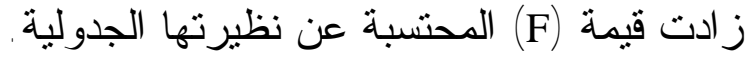

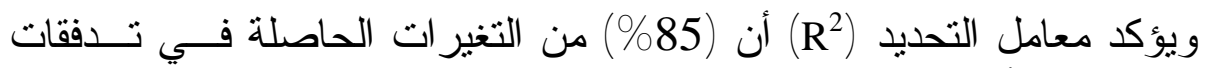

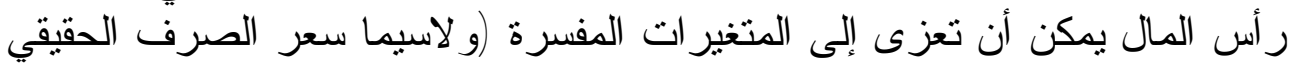

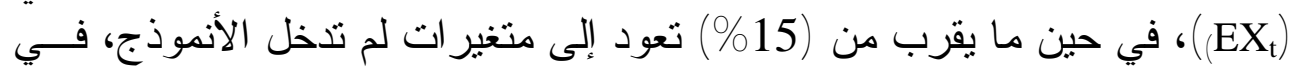

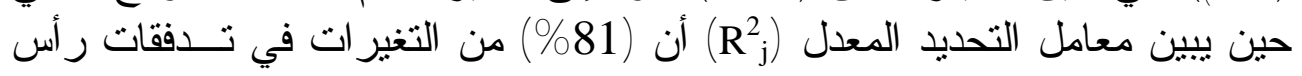

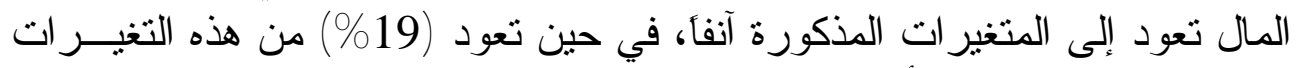
إلى متغير ات لم تدخل الأنموذج المبن.

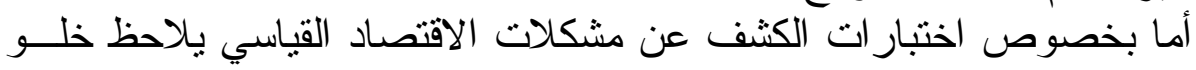

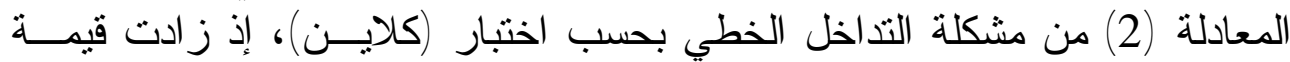

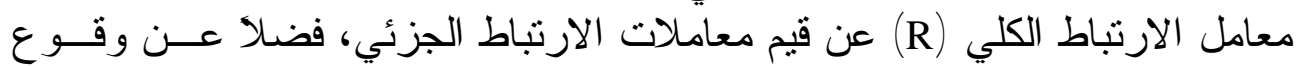

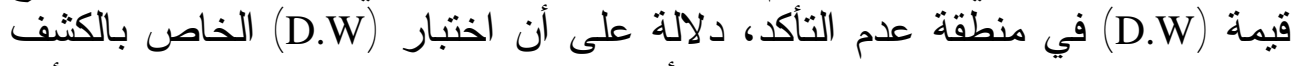

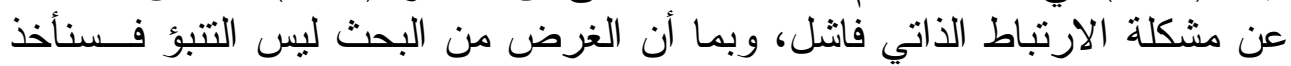
بمقدر ات هذه المعادلة.

ثالثاً - تفسير النتائج الخاصة بماليزيا

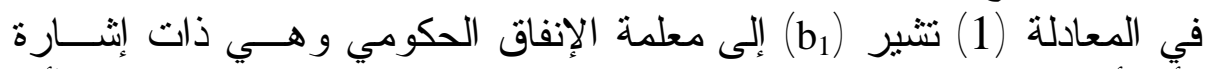

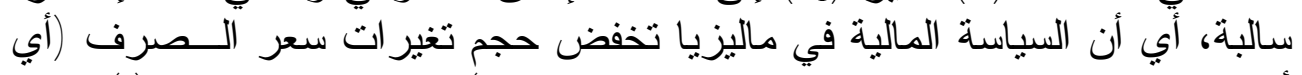

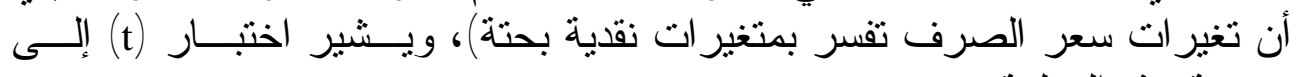
معنوية هذه المعلمة.

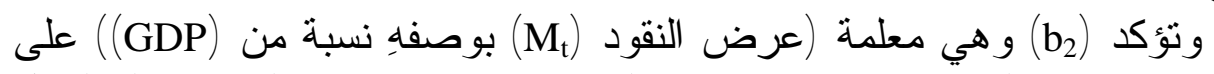

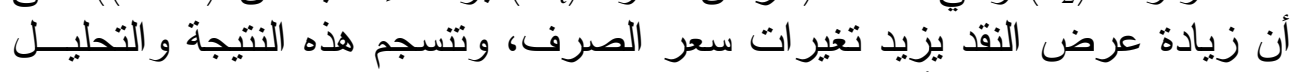

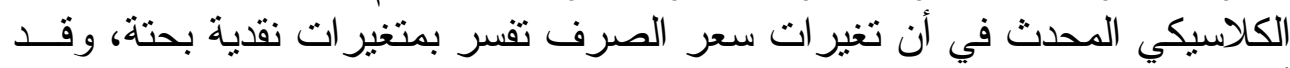

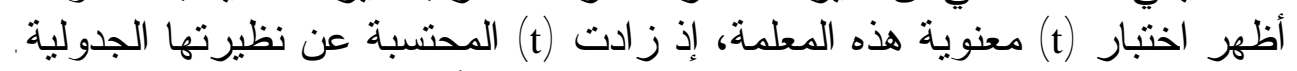

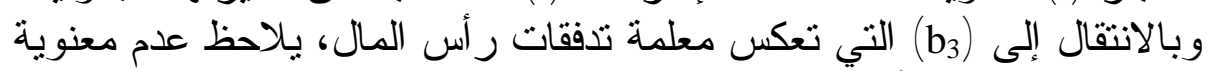

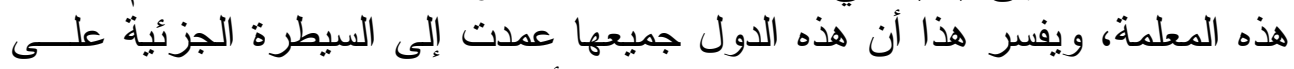

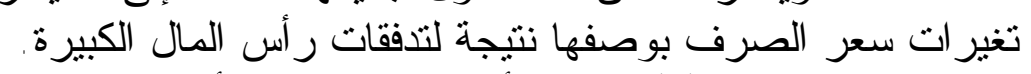

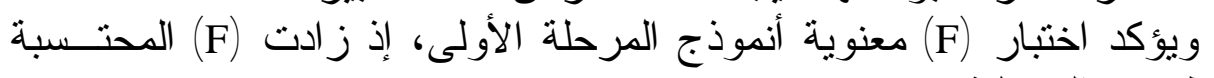

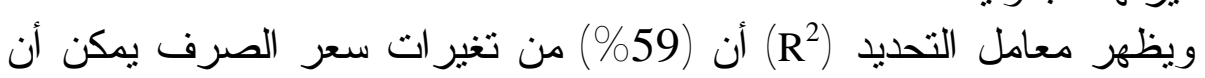

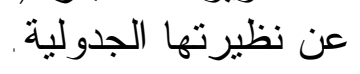

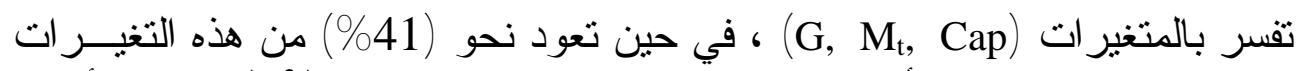

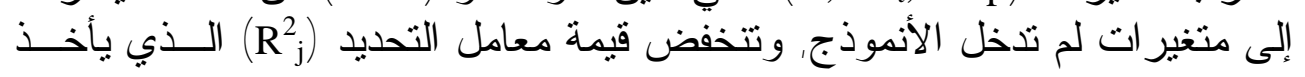

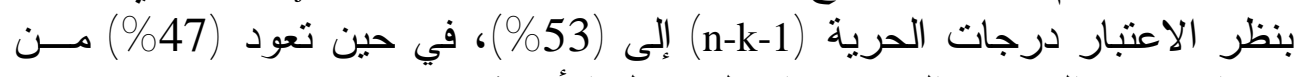
تغير ات سعر الصرف إلى متغير ات لم تدخل الأنموذج. 


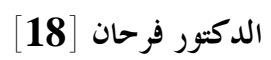

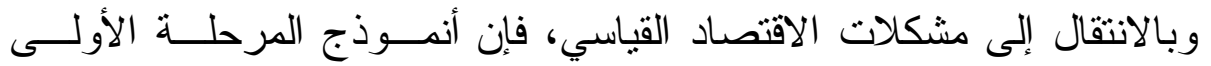

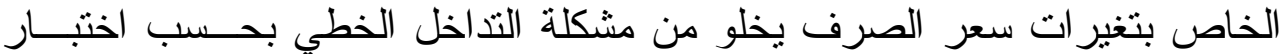

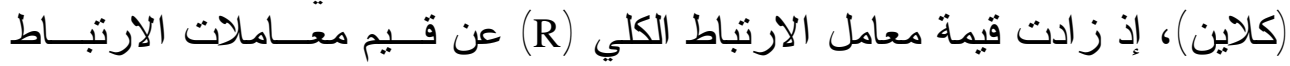
ويشير اختبار داربن وانسن (D.W) إلى أنه لا يمكن الجزم بوجود المشكلة

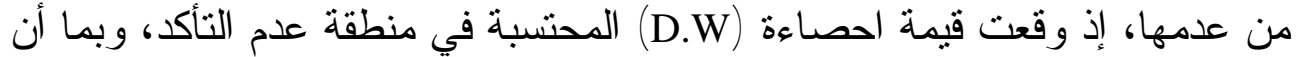

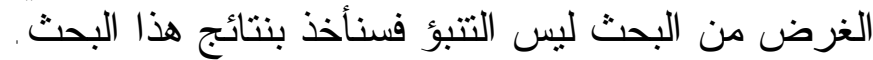

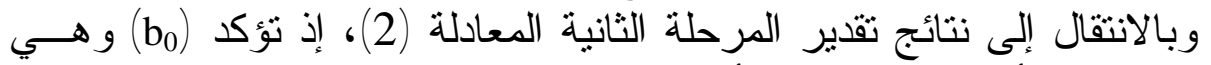

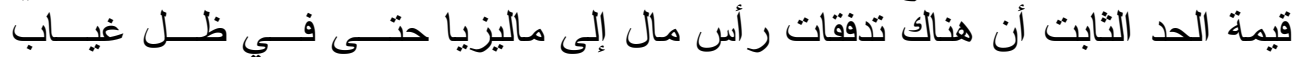

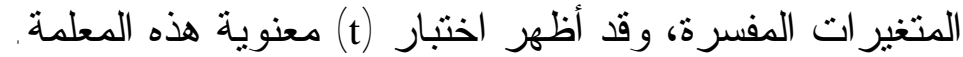

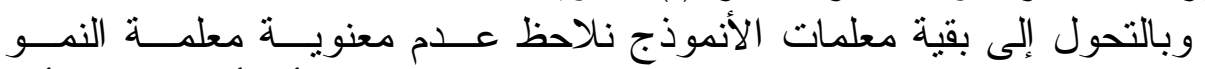

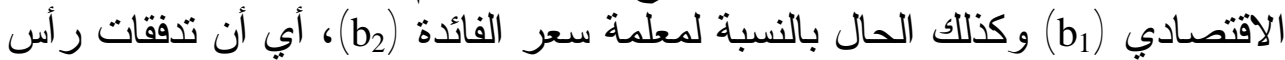

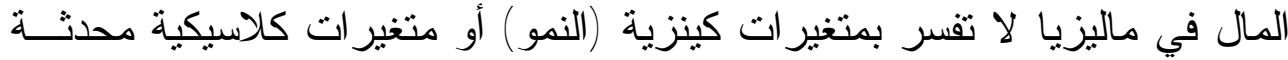

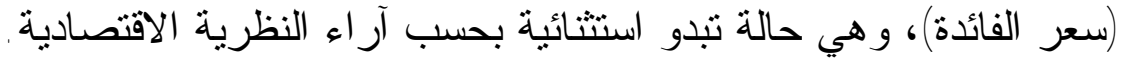

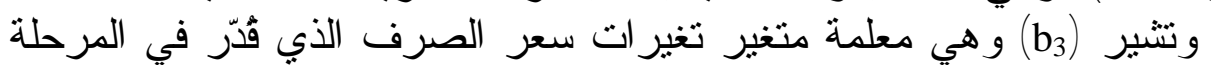

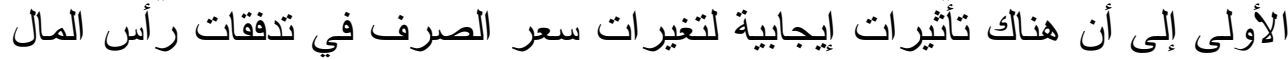

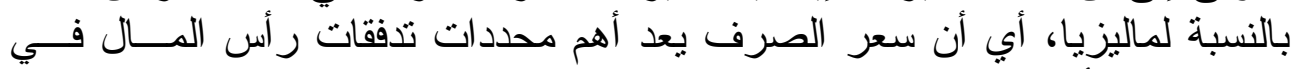

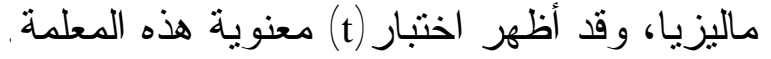

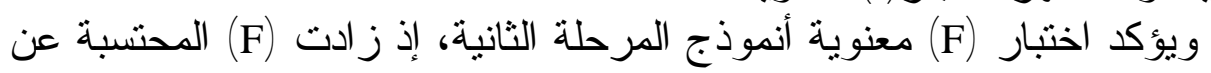

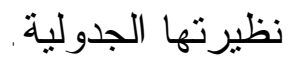

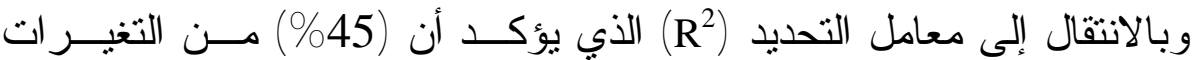

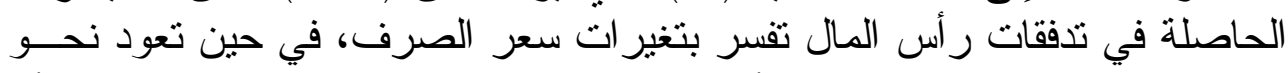

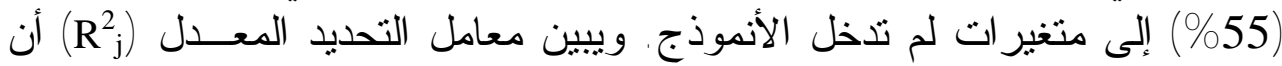

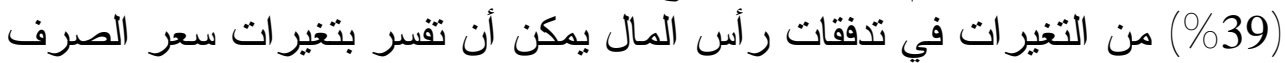

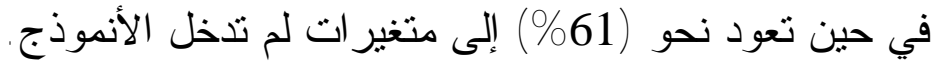

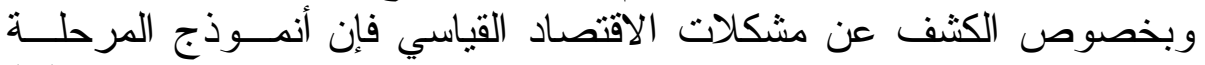

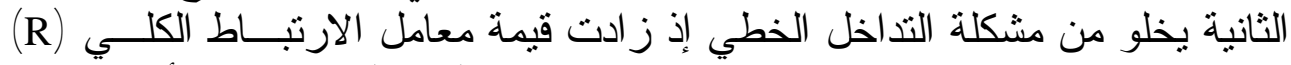

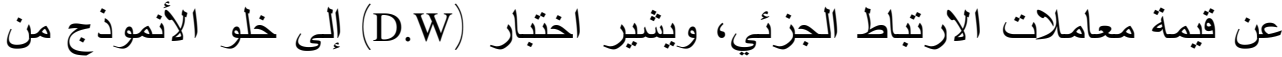

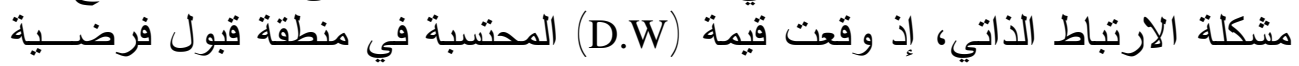

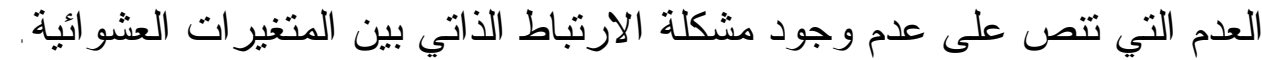

\section{رابعاً - تفسير النتائج الخاصة بأندونوسيا}

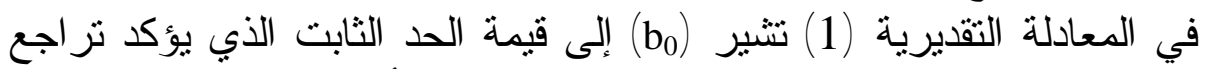

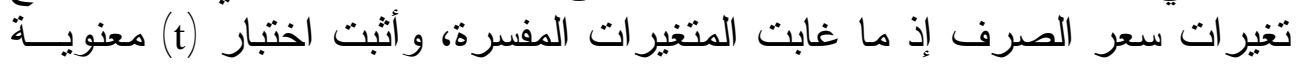




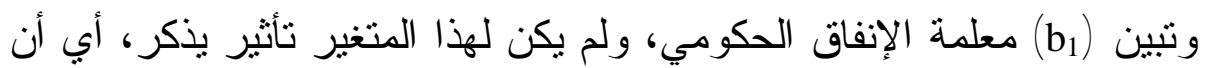

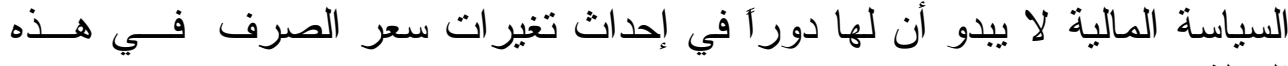

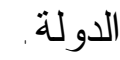

ونتير (b2) إلى معلمة عرض النقود (Mt) وقد كان تأثير هذا المتغير إيجابياً

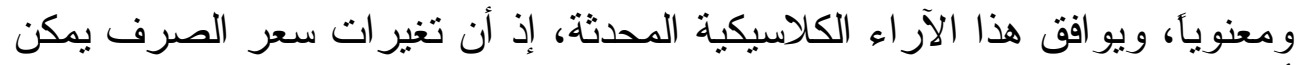

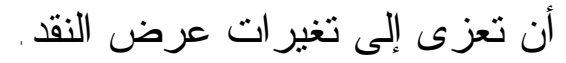

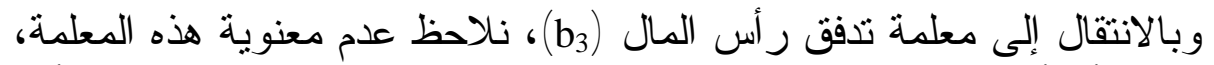

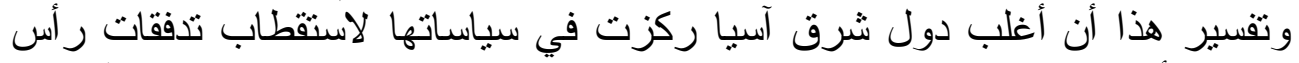

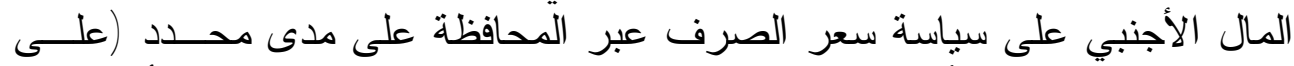

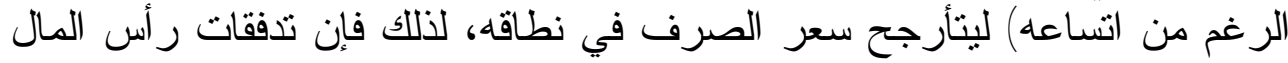

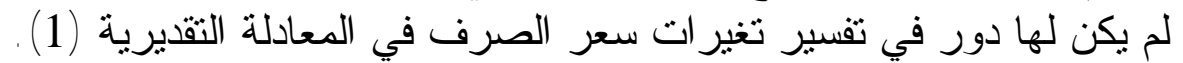

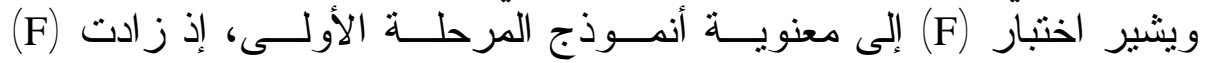

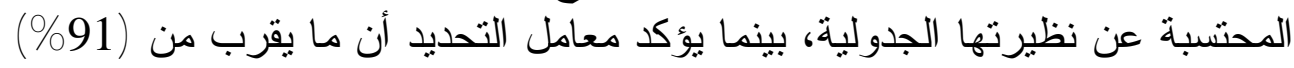

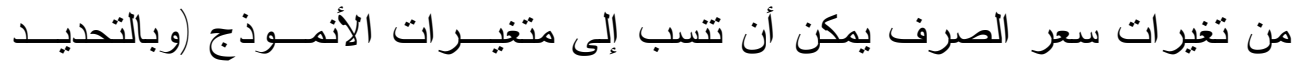

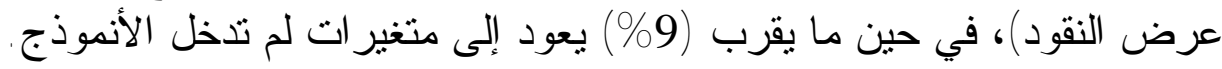

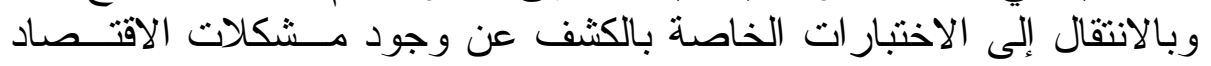

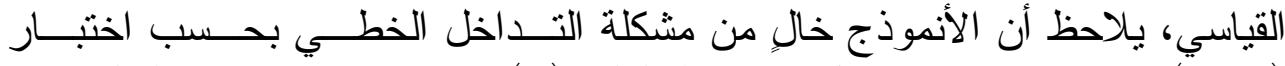

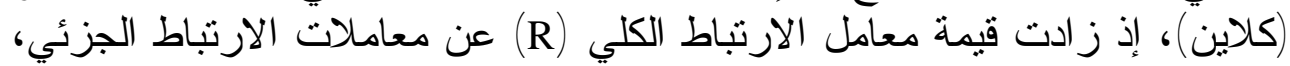

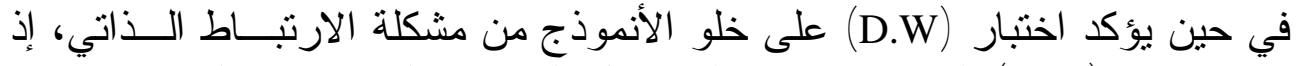

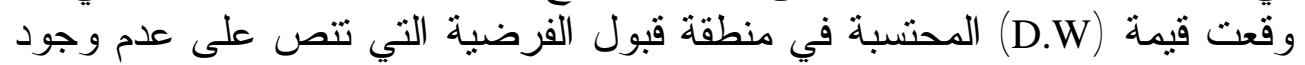
هذه المشكلة (بخيت وفتح الله ، 2002، 188 الهن -223).

\begin{tabular}{|c|c|c|c|c|c|c|c|c|}
\hline \multicolumn{9}{|c|}{ 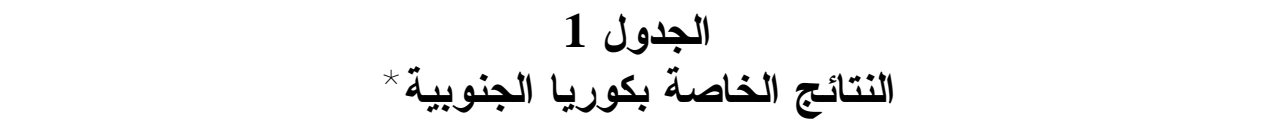 } \\
\hline المعادلة & $b_{0}$ & $b_{1}$ & $\mathbf{b}_{2}$ & $\mathbf{b}_{3}$ & $\mathbf{F}$ & $\mathbf{R}^{2}$ & $\overline{\mathbf{R}_{\mathrm{j}}}$ & D.W \\
\hline $\begin{array}{c}1 \\
(\mathrm{t})\end{array}$ & $\begin{array}{l}3.75 \\
(2.4)\end{array}$ & $\begin{array}{r}-0.12 \\
(0.17)\end{array}$ & $\begin{array}{c}0.77 \\
(1.77)\end{array}$ & $\begin{array}{c}0.14 \\
(0.55)\end{array}$ & 6.4 & 43.5 & 35.5 & 1.99 \\
\hline $\begin{array}{l}2 \\
(\mathrm{t})\end{array}$ & $\begin{array}{c}-5.8 \\
(-5.4)\end{array}$ & $\begin{array}{c}(-0.4) \\
(-0.74)\end{array}$ & $\begin{array}{l}0.07 \\
0.85\end{array}$ & $\begin{array}{c}1.15 \\
(7.65)\end{array}$ & 24.5 & $\% 85$ & $\% 81.3$ & 1.57 \\
\hline
\end{tabular}

* استخدت الدالة الخطية الني أعطت أفضل توفيق لمعادلة الانحدار .

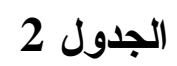

النتائج الخاصة بماليزيا

\begin{tabular}{|c|c|c|c|c|c|c|c|c|}
\hline المعادلة & $\mathbf{b}_{\mathbf{0}}$ & $\mathbf{b}_{\mathbf{1}}$ & $\mathbf{b}_{\mathbf{2}}$ & $\mathbf{b}_{\mathbf{3}}$ & $\mathbf{F}$ & $\mathbf{R}^{\mathbf{2}}$ & $\mathbf{R}_{\mathbf{j}}$ & D.W \\
\hline 1 & 1.54 & -0.61 & 0.3 & 0.06 & 9.63 & 59 & 53 & 1.54 \\
\hline
\end{tabular}




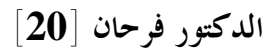

\begin{tabular}{|c|c|c|c|c|c|c|c|c|}
\hline$(\mathrm{t})$ & $(1.6)$ & $-(3.4)$ & $(2.64)$ & $(0.64)$ & & & & \\
\hline 2 & 1.12 & -0.05 & 0.04 & 0.11 & \multirow{2}{*}{12.5} & 45 & 3 & \multirow{2}{*}{1.87} \\
$(\mathrm{t})$ & 1.82 & -0.3 & 0.26 & 2.41 & & & \\
\hline
\end{tabular}

الجدول 3

النتائج الخاصة بأندونوسيا

\begin{tabular}{|c|c|c|c|c|c|c|c|c|}
\hline (المعادل| & $\mathbf{b}_{\mathbf{0}}$ & $\mathbf{b}_{\mathbf{1}}$ & $\mathbf{b}_{\mathbf{2}}$ & $\mathbf{b}_{\mathbf{3}}$ & $\mathbf{F}$ & $\mathbf{R}^{\mathbf{2}}$ & $\mathbf{R}_{\mathbf{j}}$ & $\mathbf{D . W}$ \\
\hline $\begin{array}{c}1 \\
(\mathrm{t})\end{array}$ & $\begin{array}{c}-5.5 \\
(-2.55)\end{array}$ & $\begin{array}{c}1.97 \\
1.6\end{array}$ & $\begin{array}{c}1.9 \\
(6.8)\end{array}$ & $\begin{array}{c}0.1 \\
0.76\end{array}$ & 67.8 & 91.1 & 89.5 & 1.41 \\
\hline $\begin{array}{c}2 \\
(\mathrm{t})\end{array}$ & $\begin{array}{c}-5.73 \\
(-6.27)\end{array}$ & $\begin{array}{c}0.22 \\
(-1)\end{array}$ & $\begin{array}{c}-0.35 \\
-1.66\end{array}$ & $\begin{array}{c}1.05 \\
(7.7)\end{array}$ & 23 & 79.3 & 76 & 1.85 \\
\hline
\end{tabular}

النتائج و والمقترحات

أولاًا - النتائج

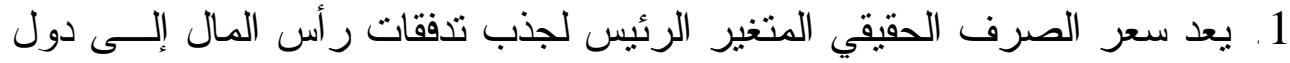

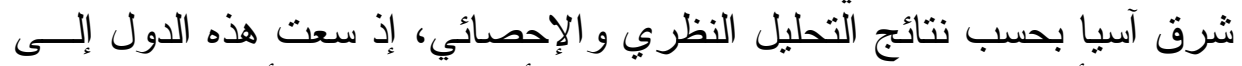

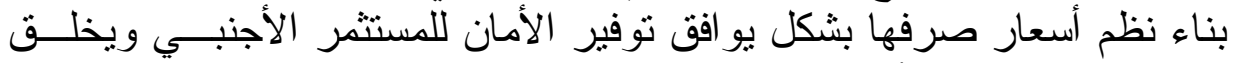

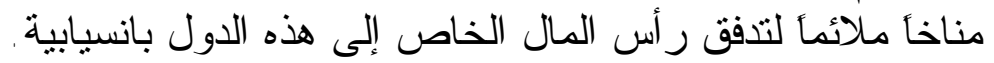

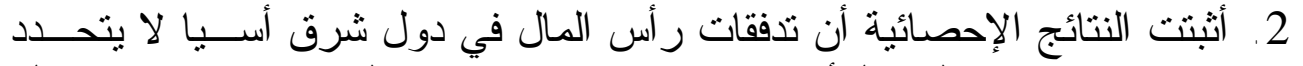

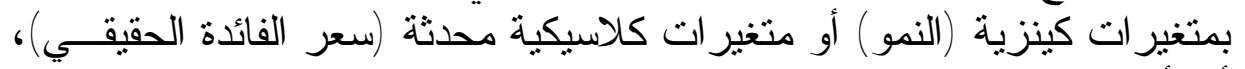

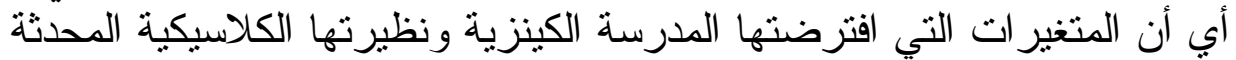

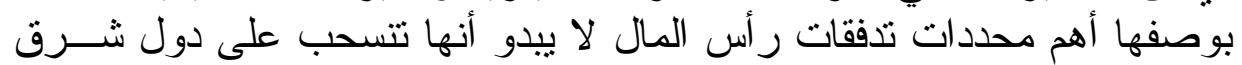
3. تفسر تغير ات أسعار صرف بمتغير ات السياسة النقدية (عرض النقود)، في حين

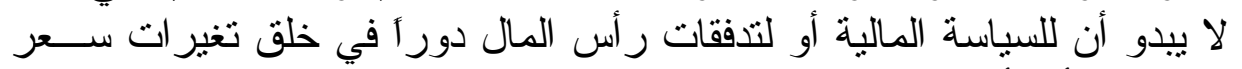

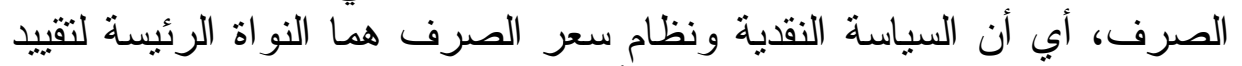
تغير ات سعر الصرف وجذب الدفيات النفات رأسمالية جديدة.

\section{ثانياً - المقترحات}

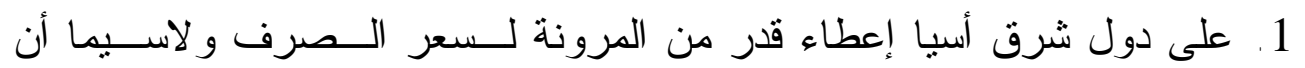

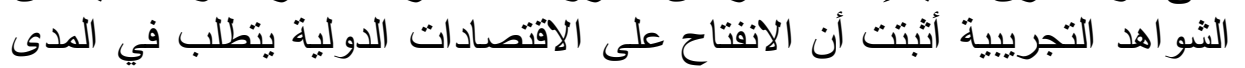

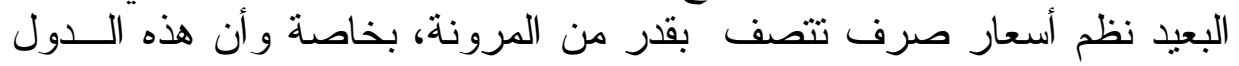

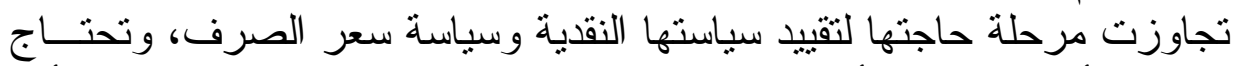
إلى نظم أسعار صرف أكبر مرونة إذا ما فكرت بجدية الأندماج في سوق رأس ونس

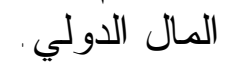



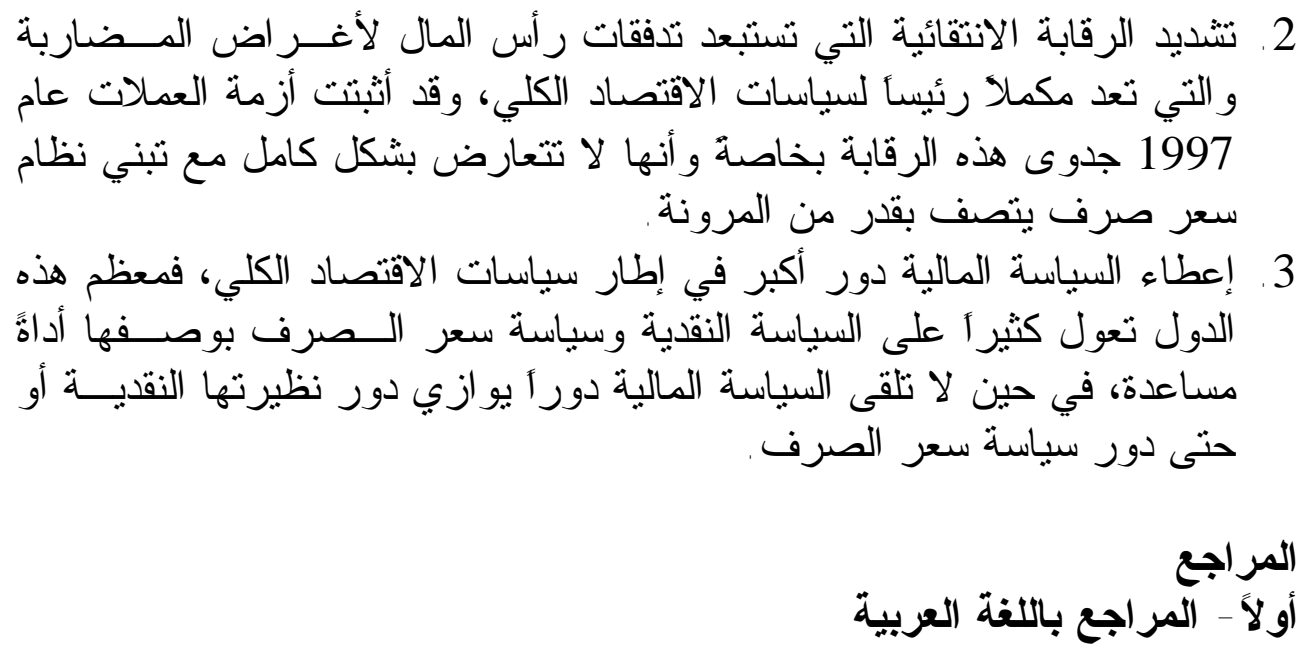

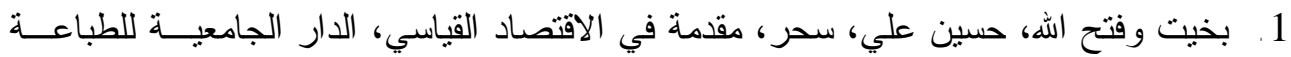

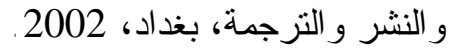

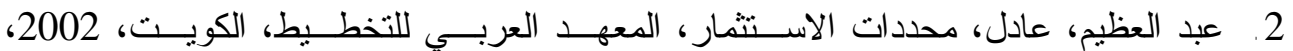
.www.arab-api.org

3. هاجن، أفيرت، اقتصاديات التتمية، ترجمة: جورج خوري، مركز الكتب الأردني، عهــان،

\section{ثانياً - المراجع باللغة الاجنبية}

1. Athukorala \& Rajapatirana, Prema- Chandra \& Sarath, Capital inflows \& the real exchange rate: A comparative Study of Asia \& Latin America,

Email: prema- Chandra. athukorala @ anu.edu

2. Begg, David, Capital Inflows, Monetary policy \& Exchange Regime, Working papers, No: 1, Macroeconomic Studies, International Center for Economic Growth, 2001

Email: dbegg@econ.bbk.ac.uk.

3. Cavoli \& S.Rajan Tony \& Ramkishe, The Capital in Flows problem in selected Asian economics in the $1990_{\mathrm{s}}$ Revisited, 2005,

Email:tony.cavoli@udelaide-edu.au, \& $\underline{\text { rrajan@ @nus.edu. Sg }}$

4. Fukuda, Shin - ichi, Post - Crisis Exchange Rate Regime in East Asia, 2004.

Email: sfukud@e.putoky. ac.jp.

5. IMF, International Financial Statistics, Washington, 2003, CD-Rom.

6. IMF, International Financial Statistics, Washington, 2006. www.IMF .org.

7. Joshi, Vijan, Financial Globali- sation, Exchange Rates \& Capital controls in Developing countries, 2003.

Email: vijay.joshi@merton.ox.ac.uk.

8. Mohey-ud-din, Ghulam, Impact of Foreign Capital Inflows on Economic Growth In Pakistan (1975-2004), Munich personal RepEc Archive, MPRA paper No.1233, 2007. http: //Mpra.ub.uni-Muenchen.de /1233/.

9. Osei, Morrissey \& Lensink, Robert, Oliver \& Robert,The volatility of Capital Flows: Measures \& Trends For Developing Countries, Centre of Research in Economic Development \& International Trade, University Nottingham, No: 2/20,2003.

www.nottingham.ac.uk / economics / research / credit . 
الدكتور فرحان [22]

10. Unctad, World Investment Report: FDI From Developing \& Transition. Economics: Implications For Development, Annexes A \& B Definitions \& Sources unctad, New York \& Geneva, 2006.

www.unctad.org.

11. World bank, World Development Indicators, Washington, 2006.

www.worldbank.org.

12. World bank, World Development Indicators, Washington, CD-Rom, 2006. 


\author{
التحديات التي تواجه تطبيق الأساليب الحديثة

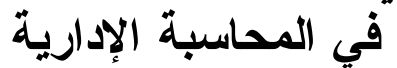 \\ دراسة لآراء عينةٌ من المحاسبين في مدينة الموصل$$
\text { مدرس مساعد- قسم المئمبة }
$$$$
\text { كلية الإدارة والاقتصاد- جامعة الموصل }
$$ \\ Muthanaalzaidy@yahoo.com
}

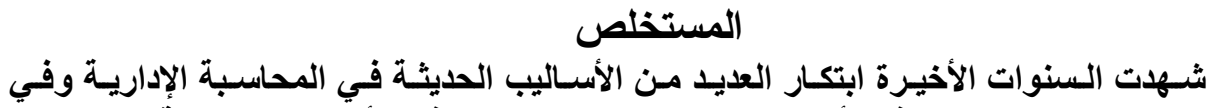

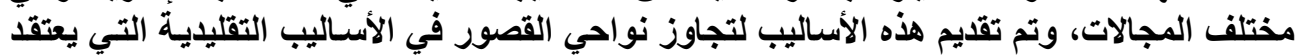

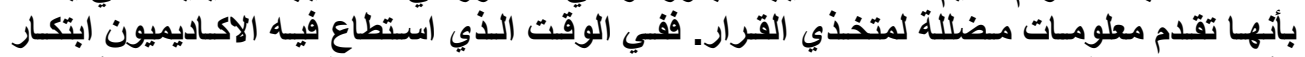

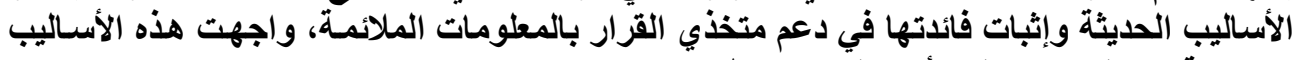

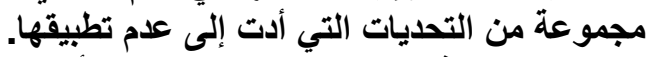

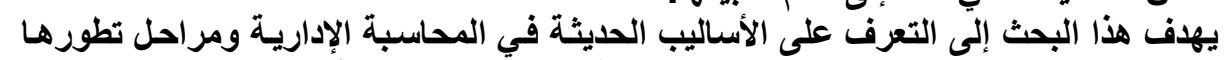

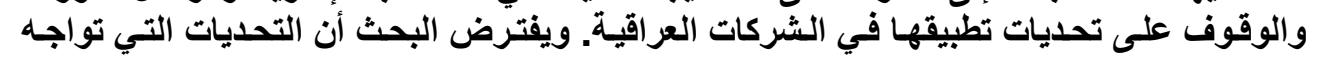

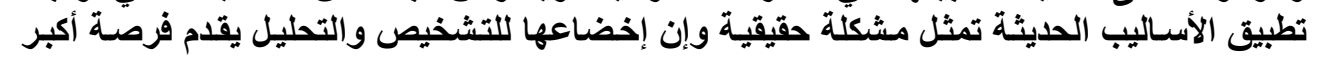

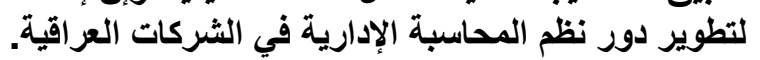

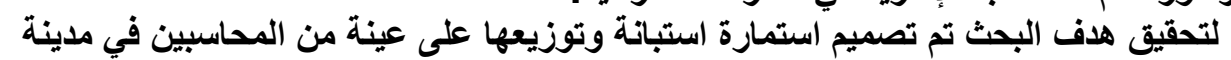

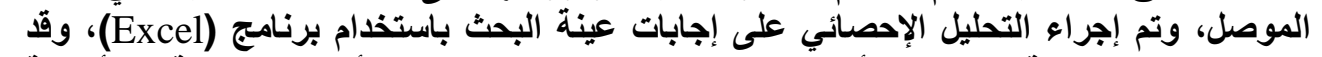

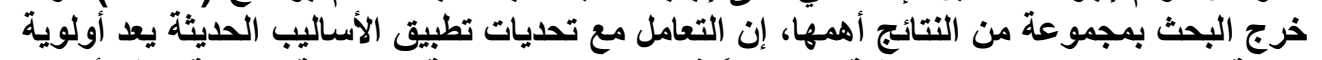

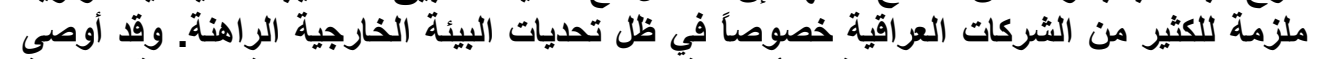

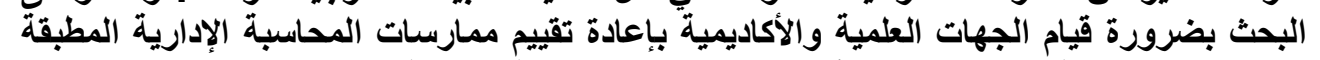

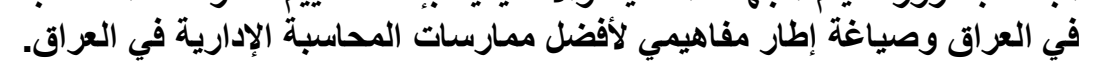

تأريخ قبول النشر 2008/12/23 تأريخ استلام البحث 2008/10/9 


\title{
The Challenges Facing the Application of Modern Management Accounting Techniques Studying for The Opinion a Sample of Accountants in the City of Mosul
}

\author{
Muthana F. Al-Zaidy \\ Assistant Lecturer \\ Collage of Administration and Economics \\ Muthanaalzaidy@yahoo.com
}

\begin{abstract}
The present research aims at identifying modern techniques of management accounting, showing the stages of their development and identifying the challenges that prevent their application in Iraqi companies. The research hypothesizes that these challenges represent a real problem, and make them subject of diagnostic analysis to provide a greater opportunity to develop the role of management accounting systems. To achieve the goal of the research, a survey form has been designed and distributed to a sample of accountants in the City of Mosul, and then statistical analysis of responses has been made to investigate the samples using (Excel). The basic conclusion of the research is to deal with the challenges of the application of modern techniques and binding to many Iraqi companies especially in the light of the challenges of the current external environment. The research recommended the need for the scientific and academic reevaluation of management accounting practices applied in Iraq and drafting a conceptual framework for a better management accounting practices.

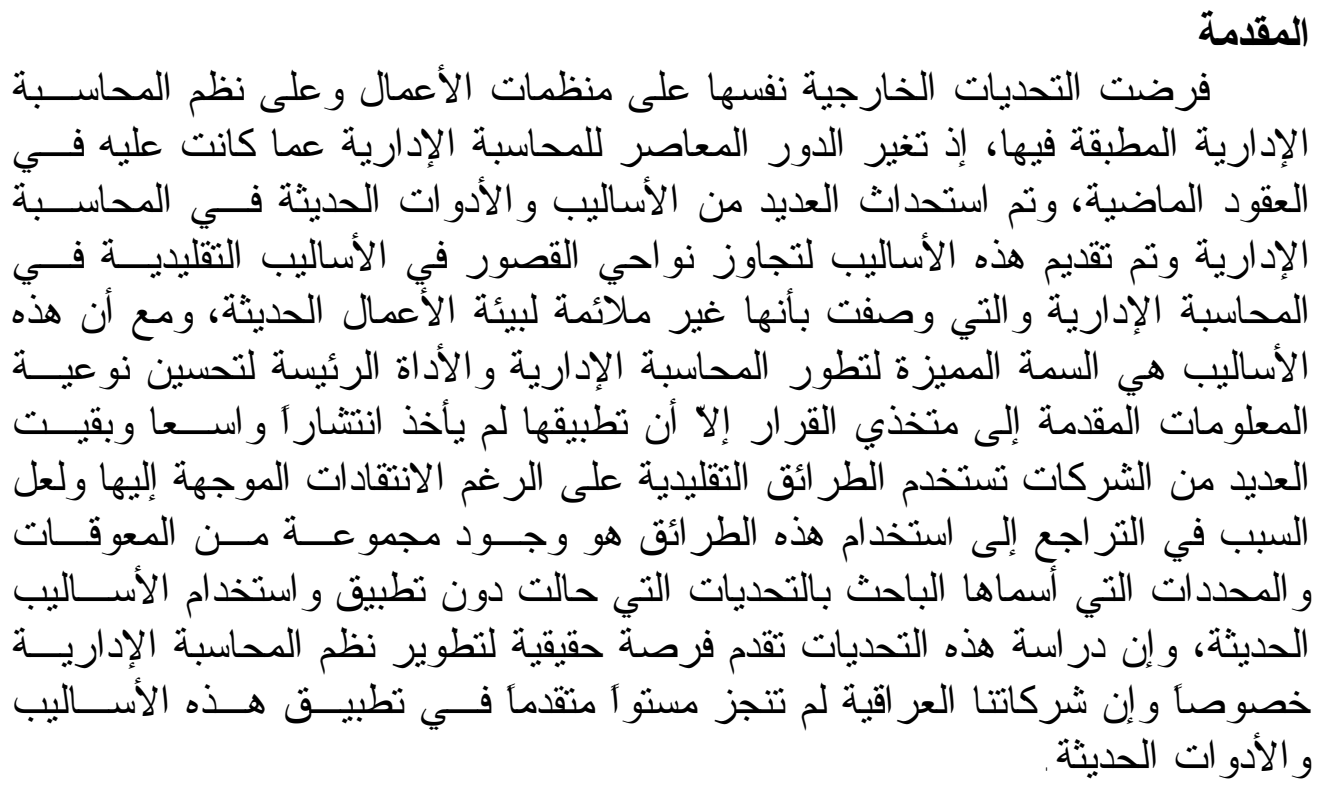


يمكن صياغة مشكلة البحث من خلال طرح التساؤ لات الآتية:

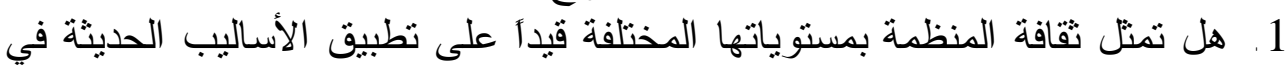
المحاسبة الإدارية في الثركات العر اقية؟

2. هل تتسجم الخبر ات العلمية و العملية التي يمتلكها المحاسب في الثركات العر اقية

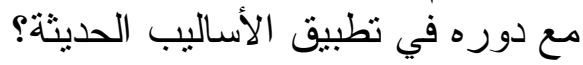
3. هل تبرر القيمة التي سوف تضيفها الأدوات و الأساليب الحديثة على أداء الثركات العر اقية النفقات اللازمة لتطبيقها؟ 4. هل تحتاج الثركات العر اقية إلى إطار مفاهيمي لممارسات المحاســبة الإداريــة

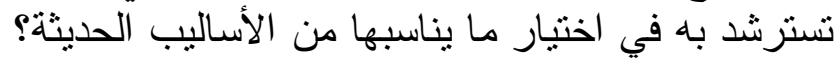

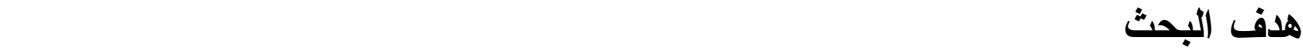
يهذف هذا البحث إلى التعرف على الأساليب الحديثة في المحاسـبـة الإداريــة

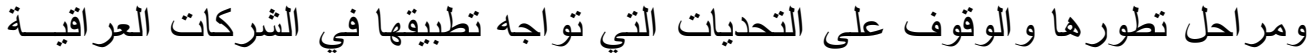
وبيان المسببات الحقيقية لها.

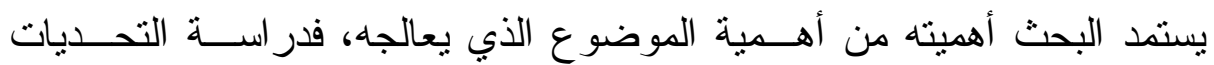

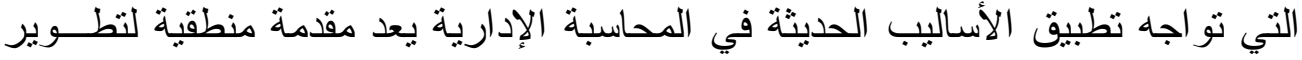

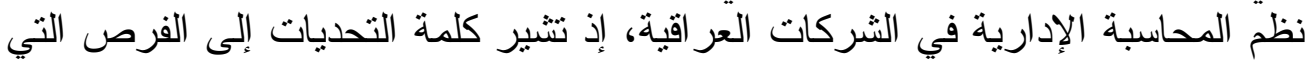
يمكن من خلالها تطوير نظم المحاسبة الإدارية، و الانتقال بها إلى مر احل متقدمة تسهر في تعزيز أداء الثركات العر اقية.

يقوم البحث على فرضية رئيسة مفادها أن التحديات التي تو اجه تطبيق الأساليب فرضية البحث

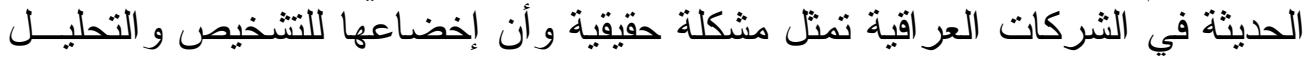

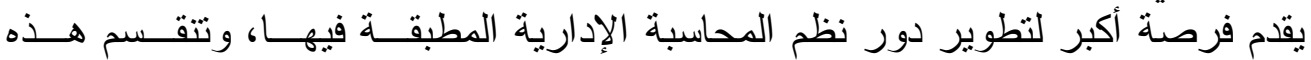
الفرضية إلى عدة فرضيات هي: ألفئ

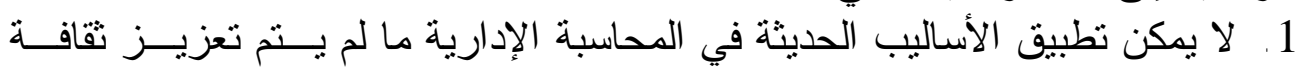
التغيير في الثركات العر اقية.

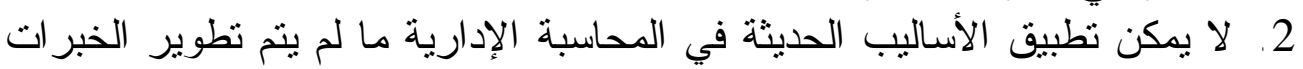

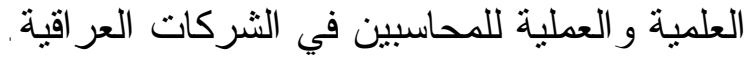




\section{الزيدي [312]}

3. لا يمثل تطبيق الأساليب الحديثة في المحاسبة الإدارية أولوية لكثير من الثركات

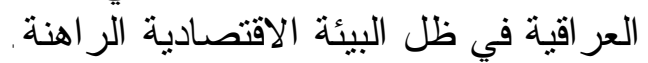

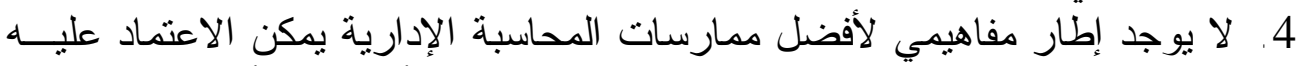
في اختيار ما يتلاءم مع حاجة الثركات العر اقية من الأدو ات و الأساليب الحديثة الأبن.

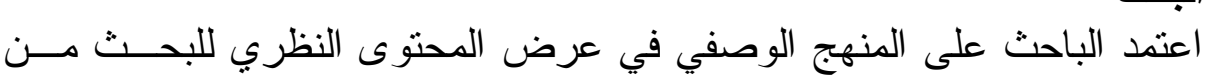

\section{منهج البحث}

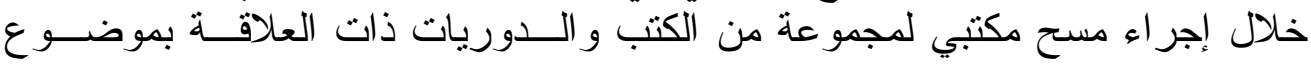

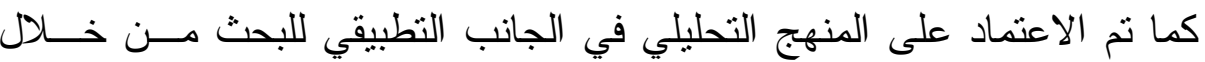

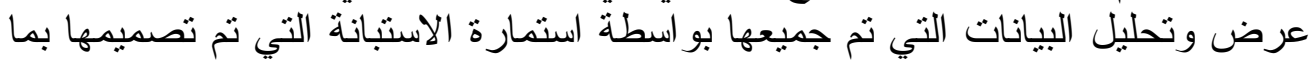

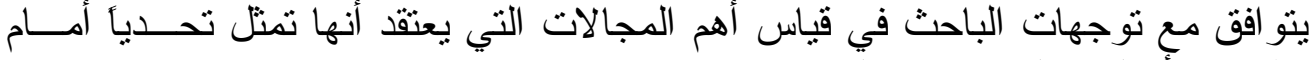

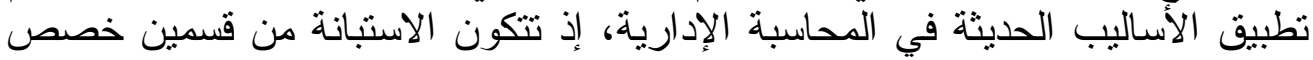

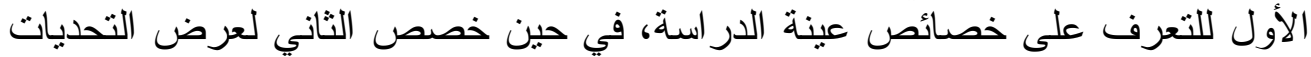

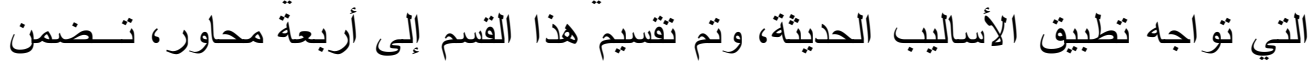

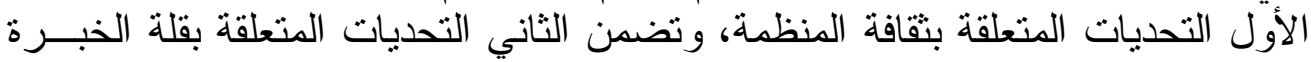

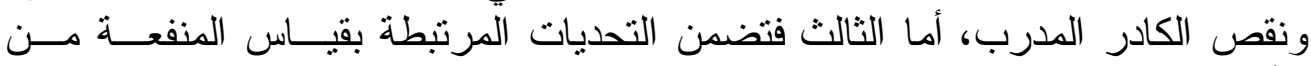
الأساليب الحديثة، في حين تضمن الرابع التحديات المتعلقة بملاءمة بحوث المحاســــة

شملت عينة البحث در اسة لآر اء عينة من المحاسبين في مدينة الموصل بكافــة

\section{عينة البحث}

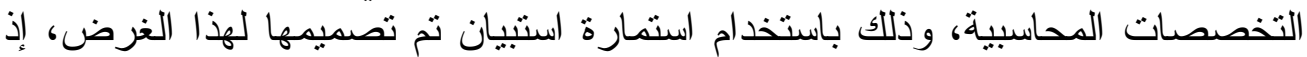

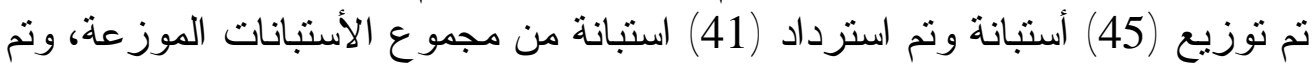

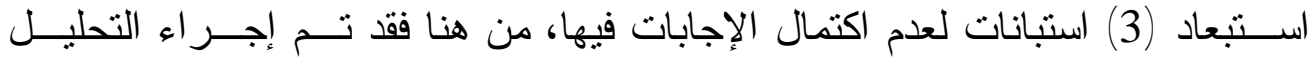

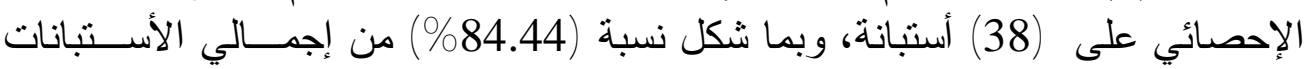
الموزعة.

\section{حدود البحث}

1. إن البحث الحالي مقيد بهدف محدد هو بيان التحديات التي تواجه تطبيق الأساليب

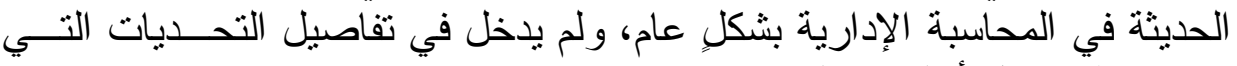
تو اجه تطبيق كل أسلوب على حدة. 
2. لم يتطرق البحث الحالي إلى بيئة و عمليات و أهداف الثركة (الإطـــار المـــوقفي)

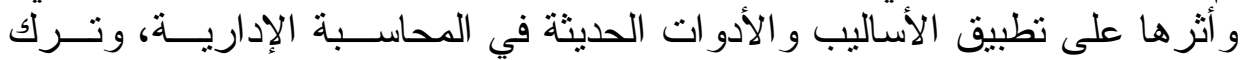

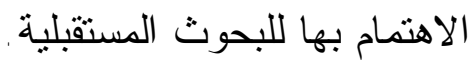

هيكلية البحث: تم تقسيم البحث على المحاور الرئيسة الآتية: - الحاجة إلى تطور المحاسبة الإدارية. - مر احل تطور المحاسبة الإدارية.

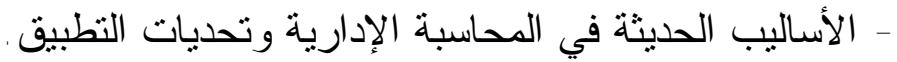
- عرض نتائج الاستبانة وتحليلها.

\section{الحاجة إلى تطور المحاسبة الإدارية}

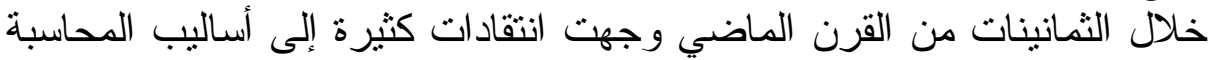

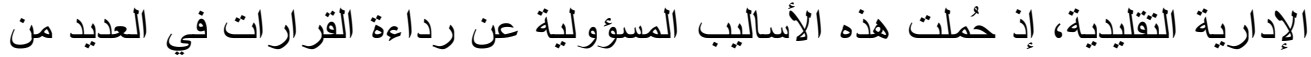

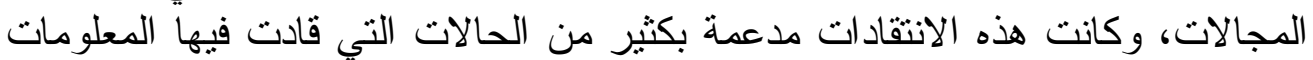

المحاسبية مدر اء الثركات لاتخاذ قر ار ات خاطئة (Dimnik \& Kuder,1989,12).

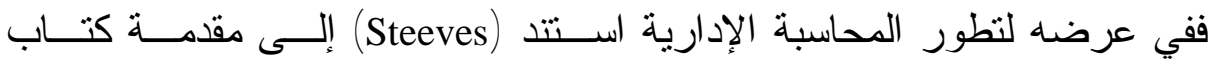

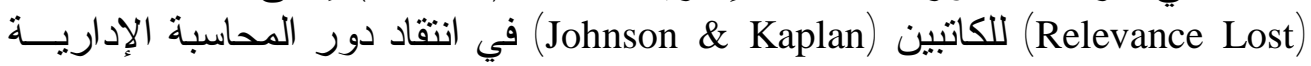

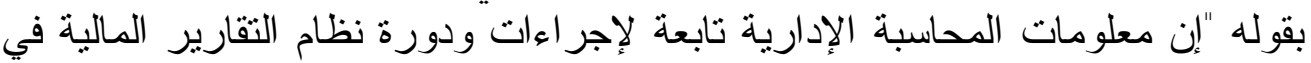

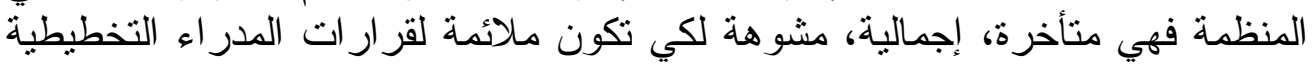

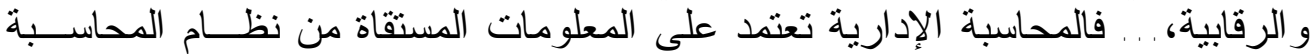

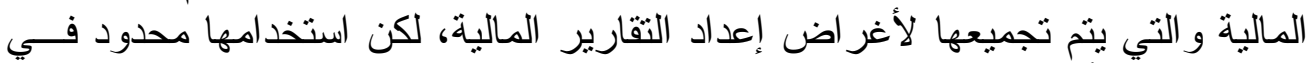
مجال قياس الأداء و الرقابة المنظمية" (Steeves, 1990, 17) .

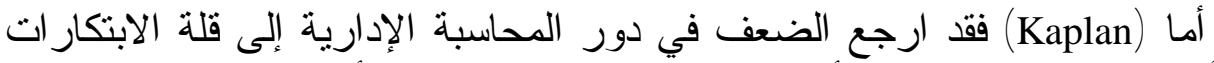

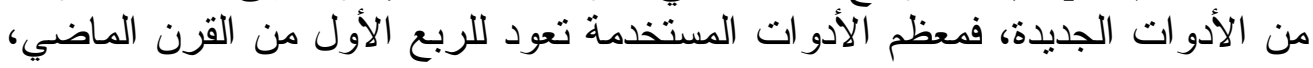

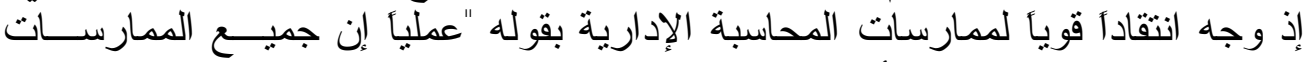

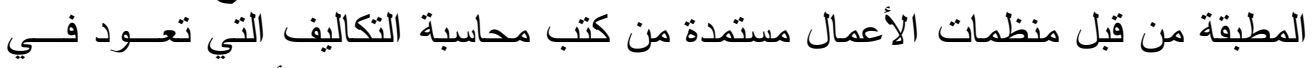

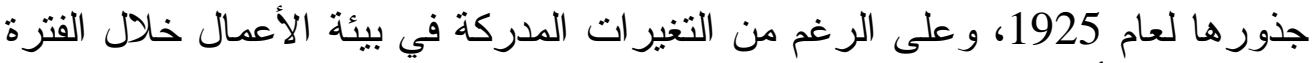

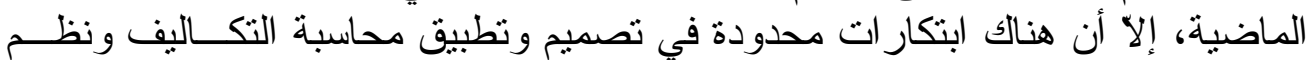

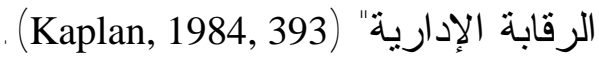

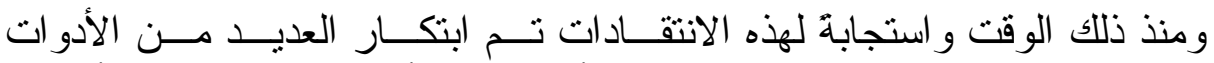

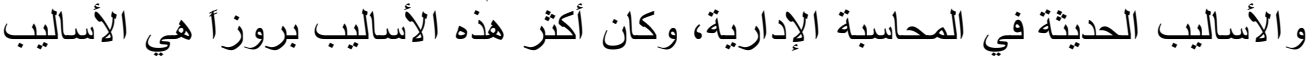

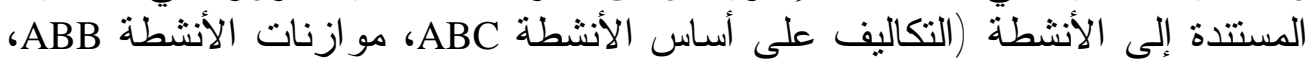




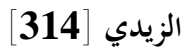

الإدارة على أساس الأنشطة ABM)، و المقارنة المرجعية (Benchmarking)، وبطاقــة

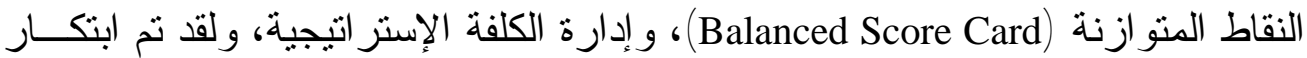

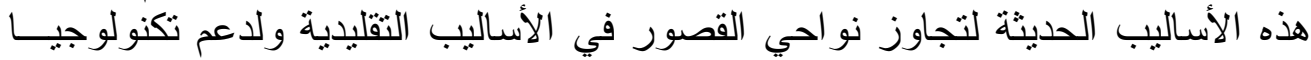

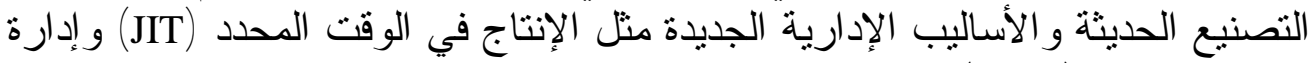

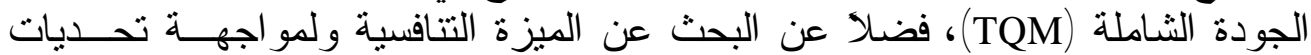

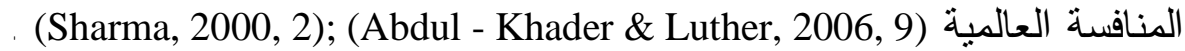

مر احل تطور المحاسبة الإدارية

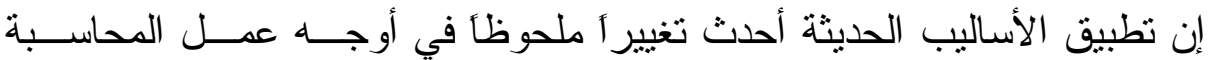

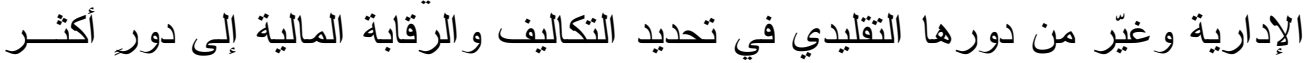

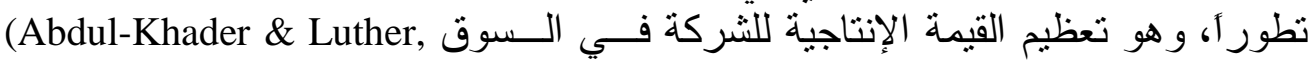
.2006, 9)

وللوقوف على الأسباب التي أدت إلىى هذا التغيير قدمت لجنـــة الإدارة الماليــة

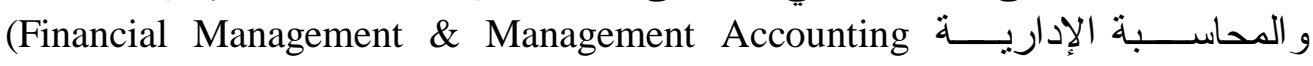
التابعة للاتحاد الدولي للمحاسبين Committee (FMAC))

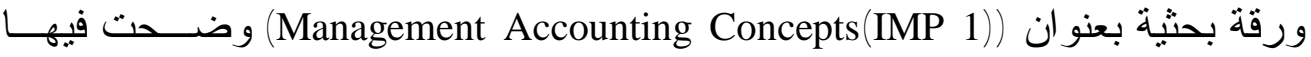

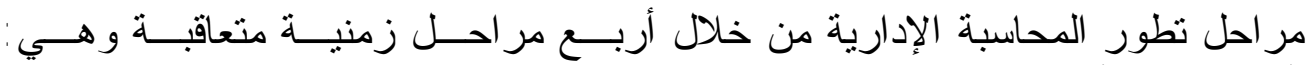
(IFAC, 1998)

\section{المرحلة الأولى: (ما قبل سنة 1950) تحديد التكاليف والرقابة المالية}

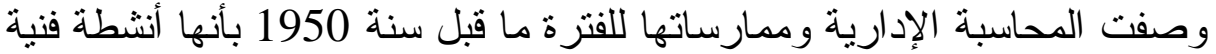

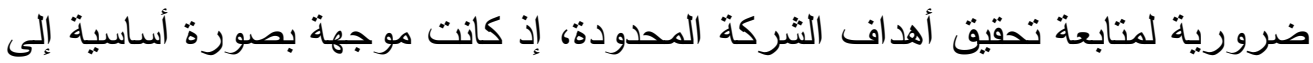

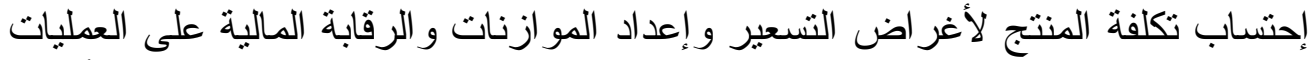

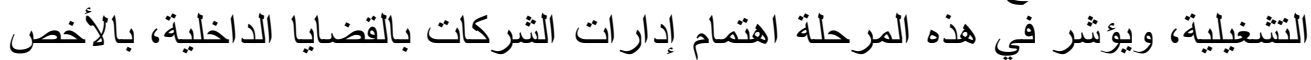

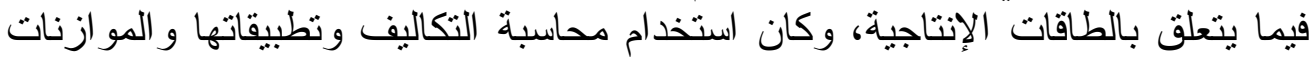

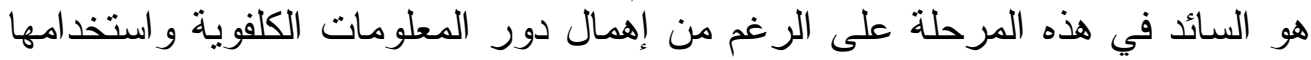

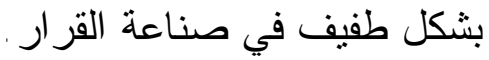

المرحلة الثانية: (من سنة1950 - لغاية سنة 1965) تــوفير المعلومــات لأغـراض التخطيط و الرقابة التمابة

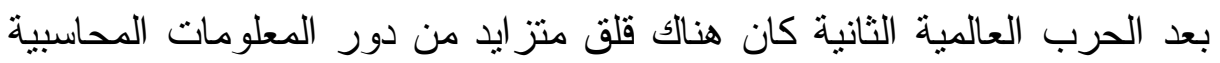
بشكل عام و المعلومات التكاليفية بشكل خاص، ومدى ملاصن ملاعمتها لاحتياجات المستخدمين،

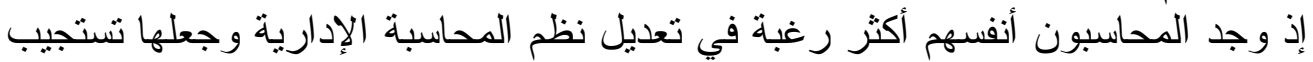


لاحتياجات الإدارة، ففي تلك الفترة تغير اهتمام المحاسبة الإدارية و أزداد تركيزها على الإدي

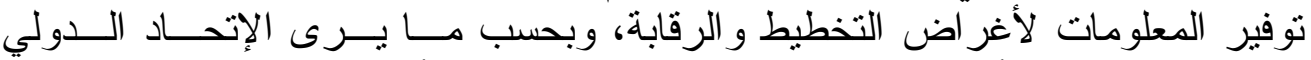

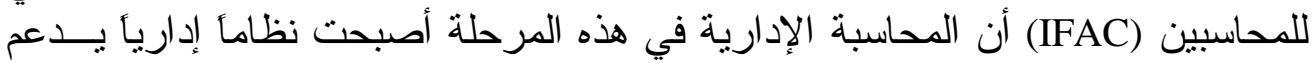

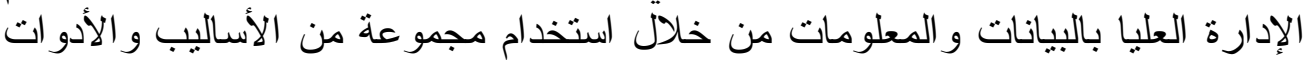

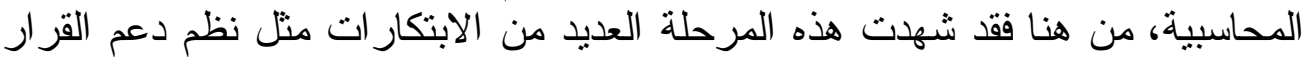

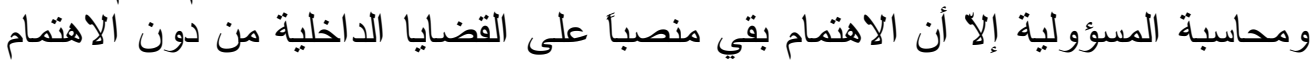

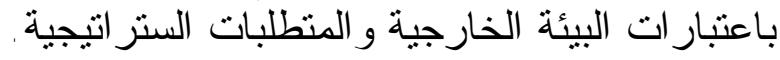

\section{المرحلة الثالثة: (من سنة 1965 - لغاية سنة 1985) تخفيض الضياع والهدر فـي الموارد}

خلال السبعينات من القرن الماضي واجهت منظمات الأعمال تحديات كبيــرة،

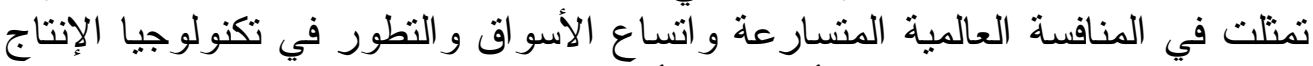

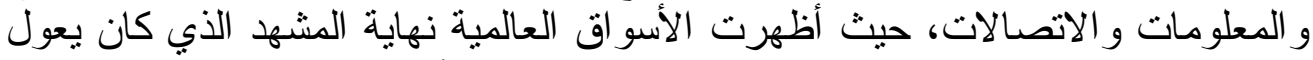

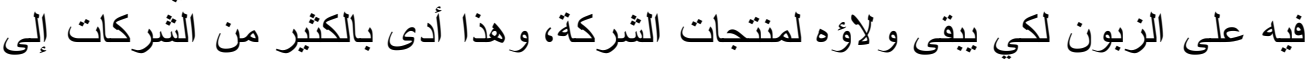

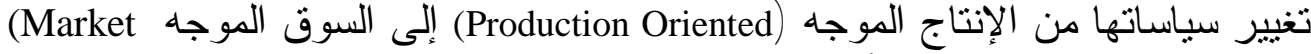

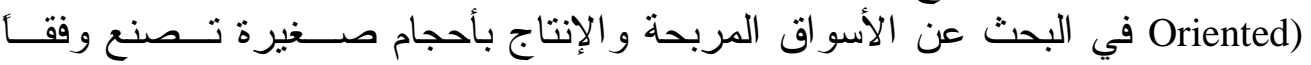
لاحتياجات الزبون (Ning, 2005, 25).

لقد أدى هذا التغير إلى توسيع قاعدة المتطلبات التقنية و الفنية و التي أدت بدور ها

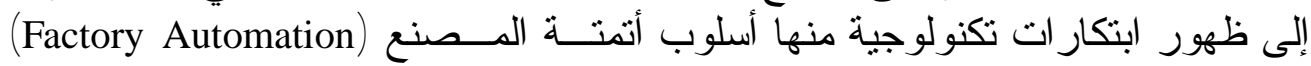

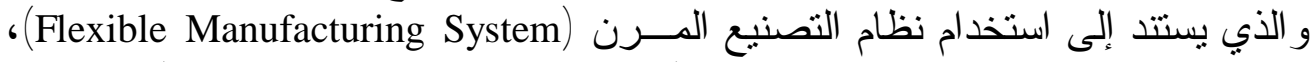

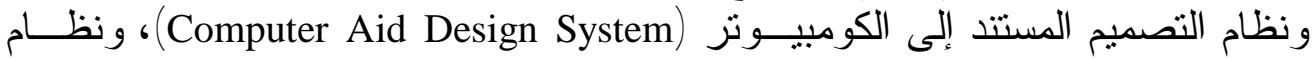

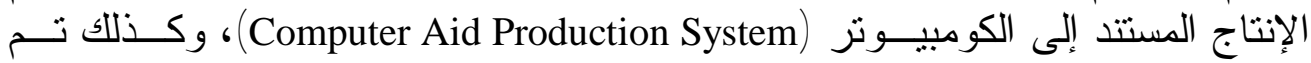
استحداث أساليب إنتاج جديدة ترنكز على درجة التقيد التقني مثل أسلوب الإنتاج فـي

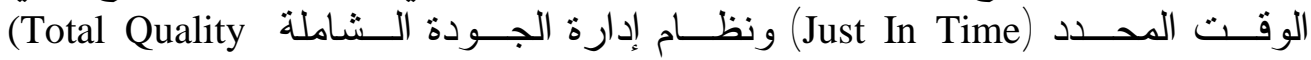
(Ning, 2005, و التي تركز على تخفيض الضياع و الهدر في المــو اردة Management) (Atkinson, 1989, 35) 25)

لقد فرضت هذه التحديات نفسها على منظمات الأعمال و على نظــــ المحاســبة

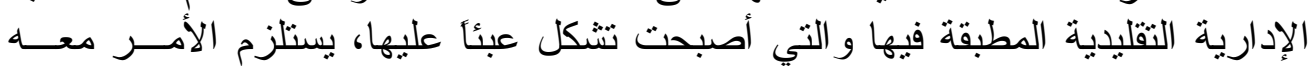

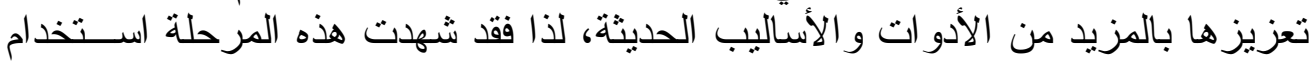

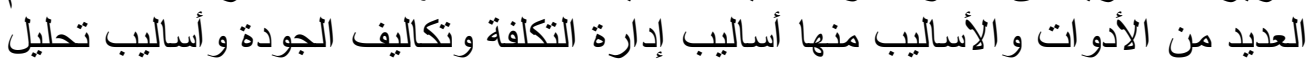




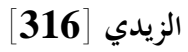

\section{المرحلة الرابعة: (من سنة 1985 - لحد الآن) تعظيم القيمة من خــلل الاســـذام

\author{
الأمثل للموارد
}

منذ بداية النصف الثاني من الثمانينات من القرن الماضي وحتى اليوم لم تــزل الإل

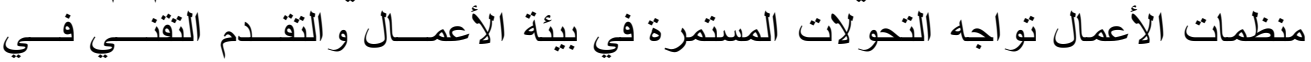

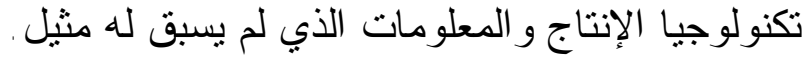

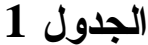

مر احل تطور أدوات وأساليب المحاسبة الإدارية

\begin{tabular}{|c|c|c|c|c|}
\hline 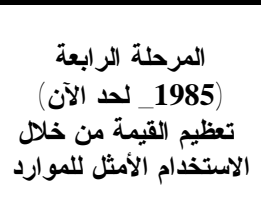 & 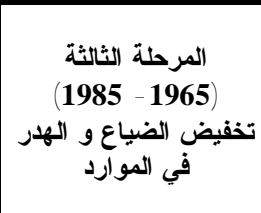 & 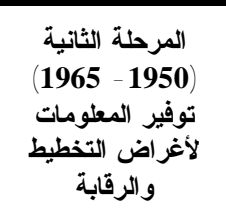 & 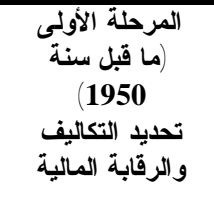 & 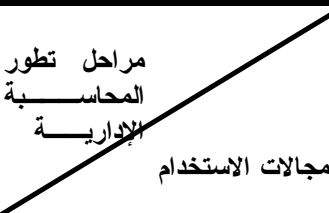 \\
\hline 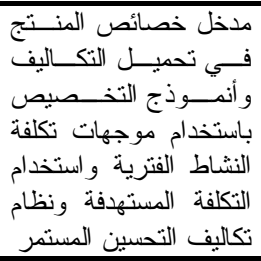 & 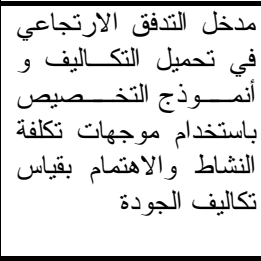 & 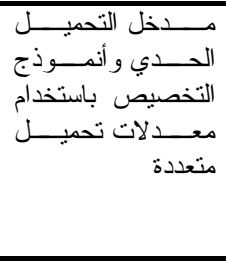 & 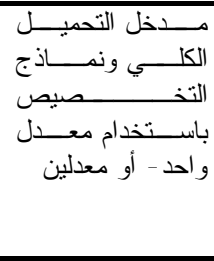 & مجال قياس التكاليف \\
\hline 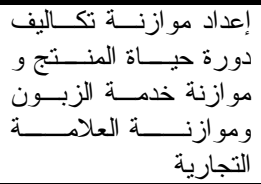 & وإعداد موازنات الجودة الأنشطة & 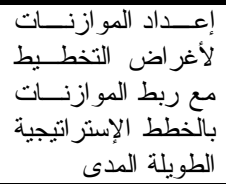 & 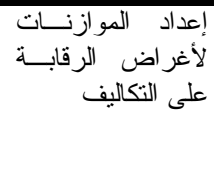 & 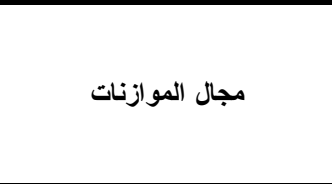 \\
\hline 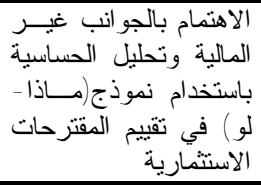 & 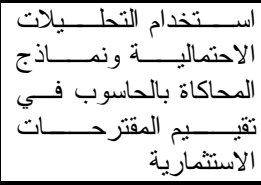 & 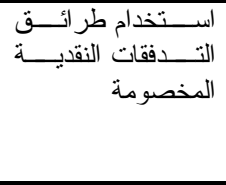 & 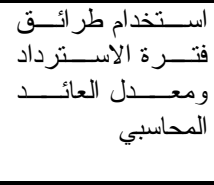 & مجال الموازنات الرأسمالية \\
\hline 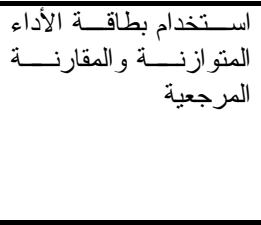 & 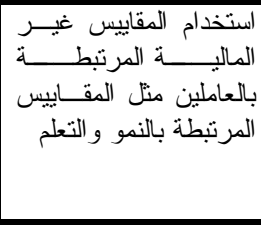 & 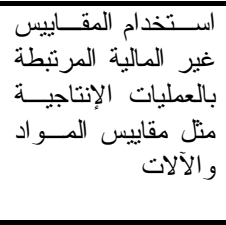 & 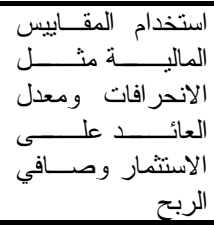 & مجال الرقابة التشغيلية وتقييم \\
\hline 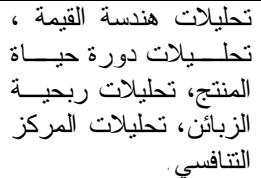 & 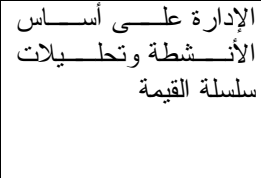 & 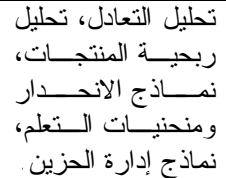 & 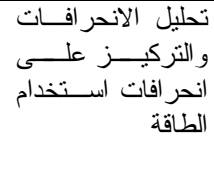 & مجال دعم القرار \\
\hline
\end{tabular}


فعلى سبيل المثال إن الاستخدام الواسع لشبكة الانترنت أدى إلى ظهور التجارة

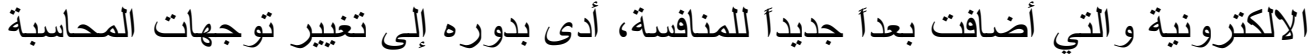

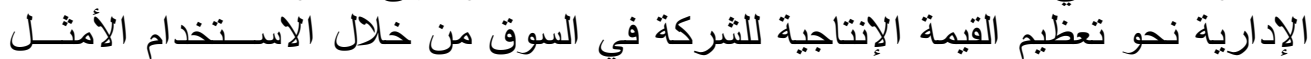

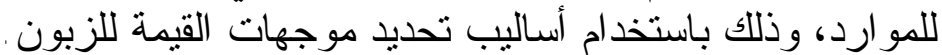

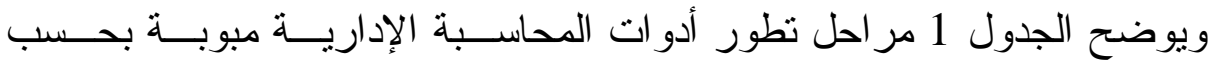
مجالات استخدام المحاسبة الإدارية في المنظمة.

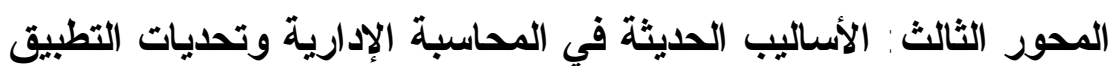

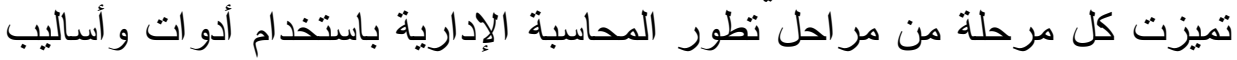

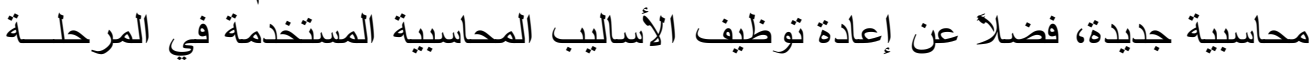

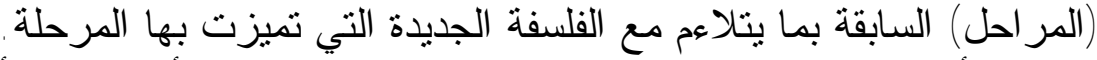

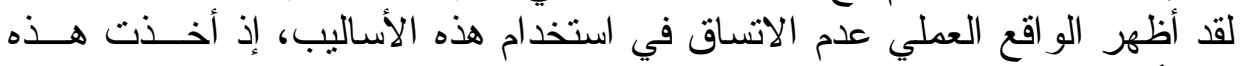

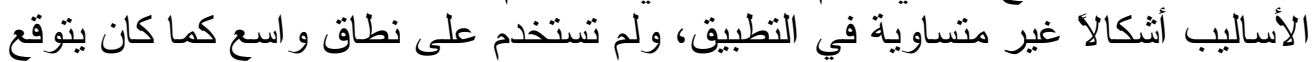

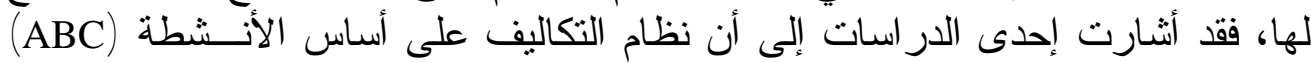

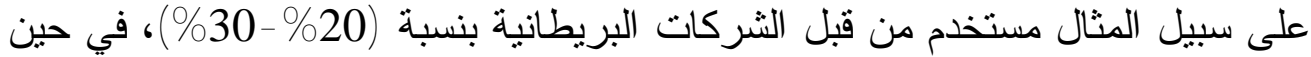

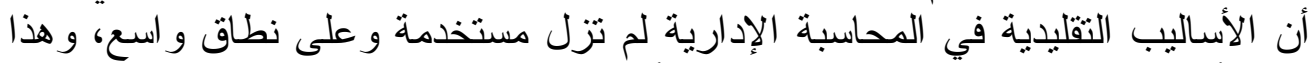

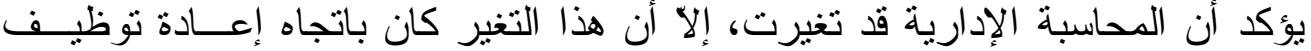

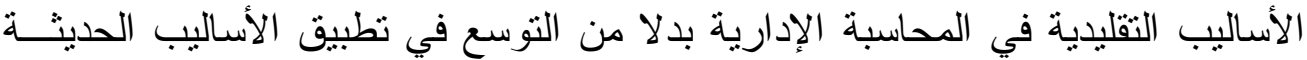
(بتصرف (Burns,2000,2) (Steeves,1990,18) و هذا يقودنا إلى التساؤل لماذا تتغير المحاسبة الإدارية ببطئ شديد ور اء التغير ات

المتسار عة في بيئة الأعمال الحديثة؟ الفئ

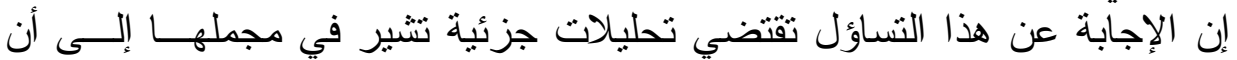

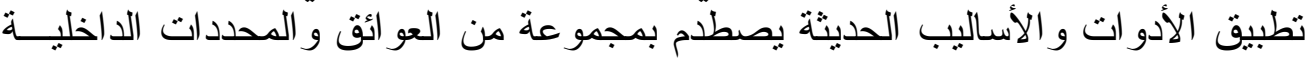

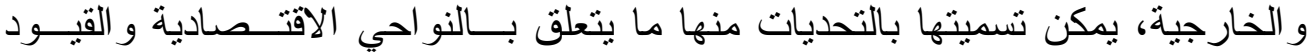

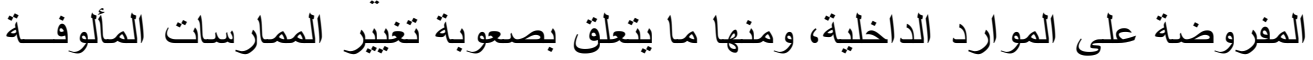
التي قد تحول دون تطبيق هذه الأدوات و الأساليب و التي يمكن عرضها باتئ بالثكل الآتي:

أ. المنظمة وثقافة التغيير

إن تطبيق الأساليب و الأدو ات الحديثة بتطلب خلق التق البيئة التي يقتنع فيها الأفر اد في

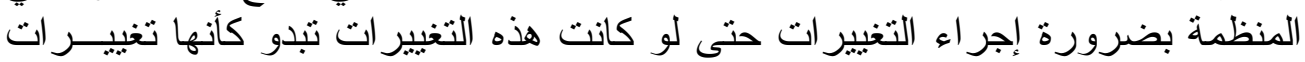

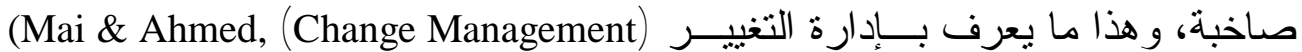




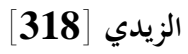

و هنا يمكن تحديد ثلاثة مستويات من التحديات المرتبطة بثقافة المنظمة التي تو اجه تطبيق الأساليب الحديثة و هي (www.esnips.com/search/costaccounting) :

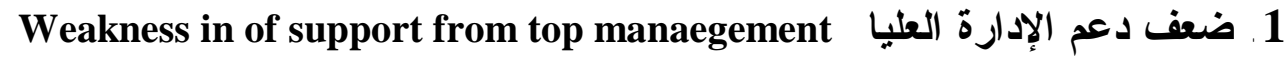

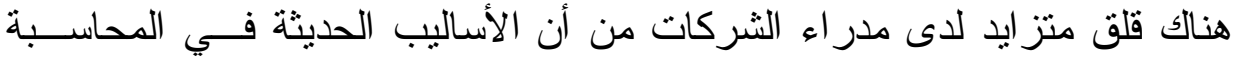

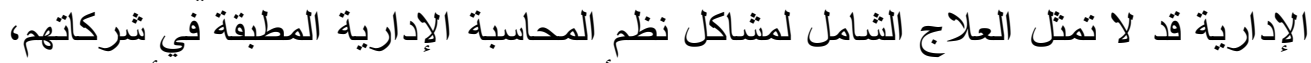

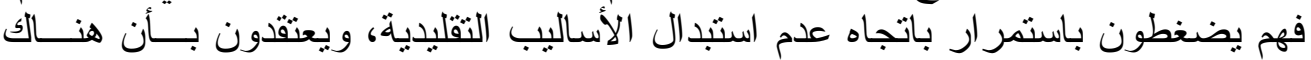

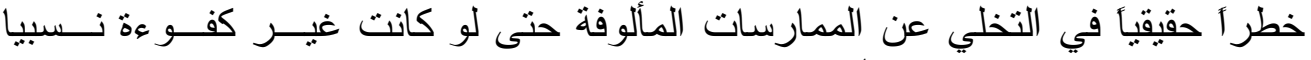
. (Dimnik \& Kuder,1989,14)"

ومن جانب آخر فإن المختصين في المحاسبة الإدارية يتحركون باتجاه مــشاركة

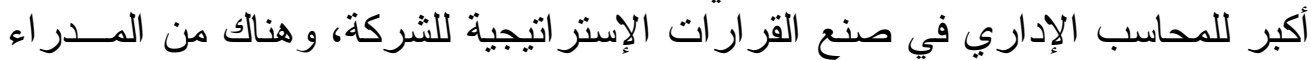

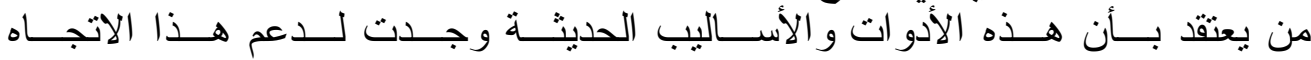
(Steeves,1990,18)

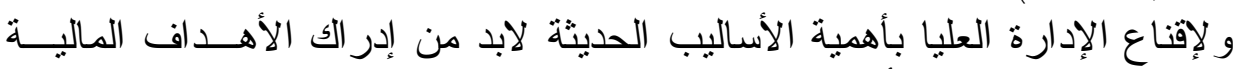

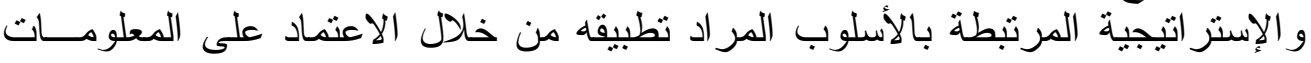

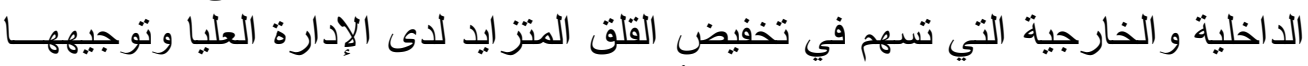

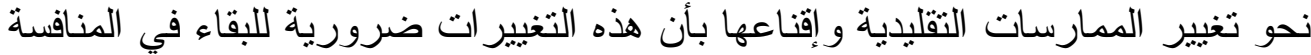
. (Mai \& Ahmed,2005,46)

2. معارضة الكادر المحاسبي للتغيير \&esistance from Staff to change

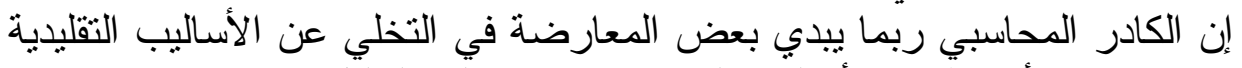

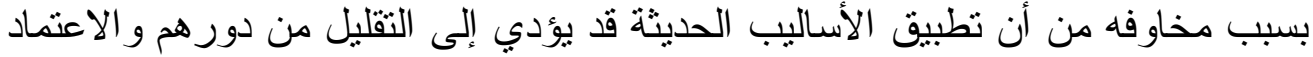

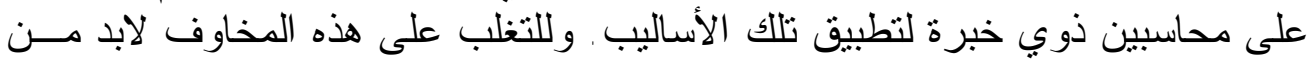

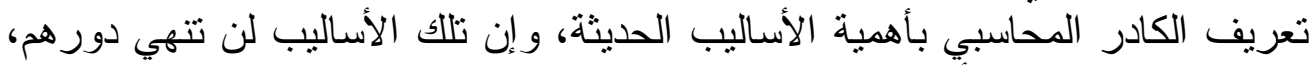

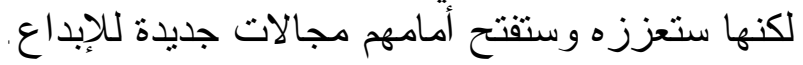

3.عدم تعاون المستويات الأخرى Non-cooperation at other levels

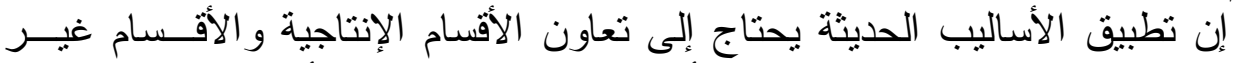

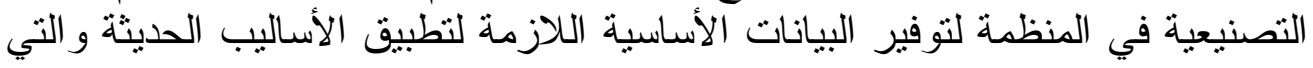

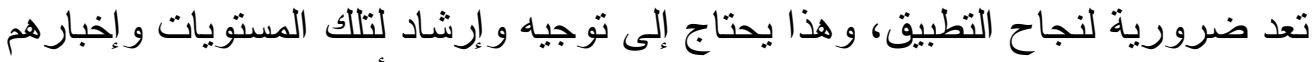

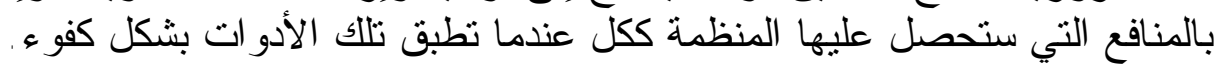

ب. قلة الخبرة لاى المحاسبين الإداريين ونقص الكادر المدرب

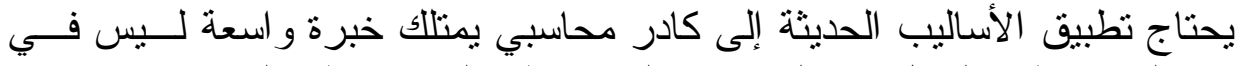
الجوانب المحاسبية فقط، بل في المجالات التصنيعية و التـسويقية و المجــالات غيــر 


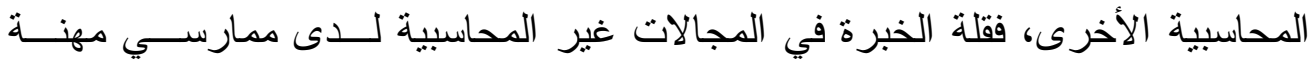

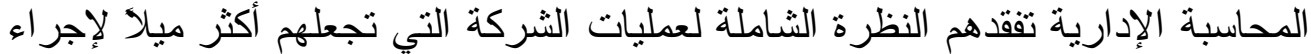
التغيير ات في نظم المحاسبة الإدارية وتعزيز ها بالمزيد من الأساليب و الأدوات التهات الحديثة . (Mai \& Ahmed, 2005, 48) (Sheildes, et.al,1991, 72)

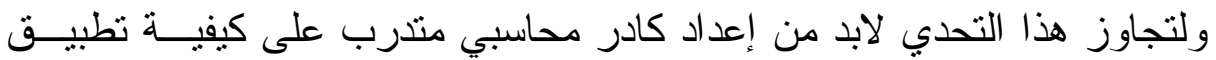

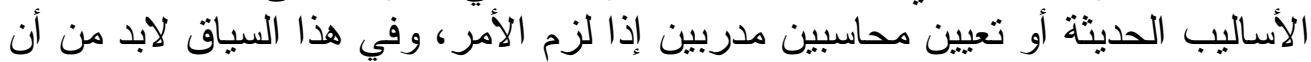

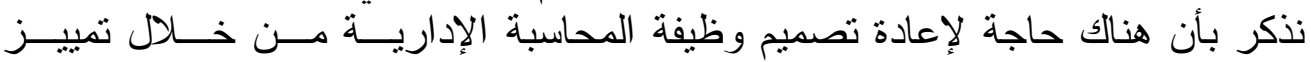

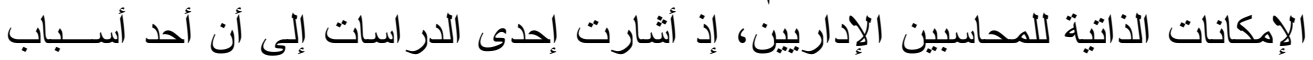

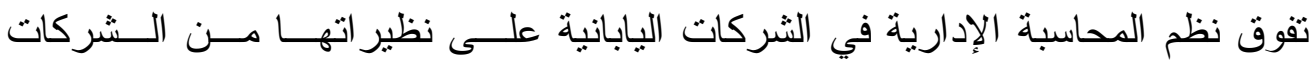

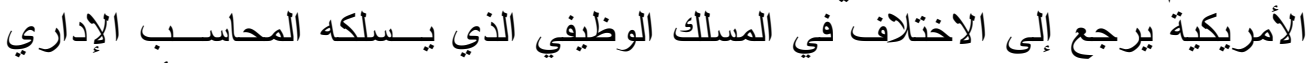
ومحاسب التكاليف في كلا البلدين، فمعظم محاسبي التكاليف في الثركات فئ الأمريكية ينت

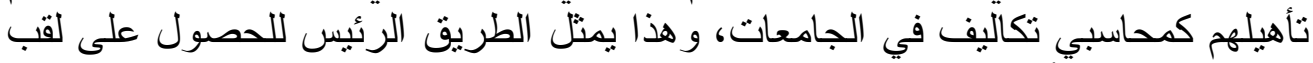

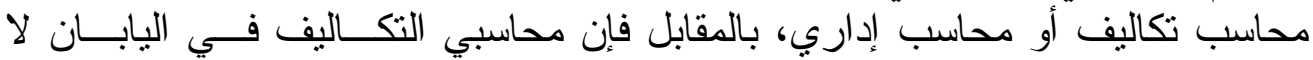

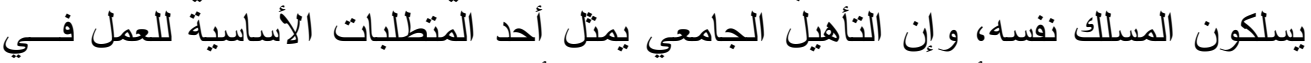

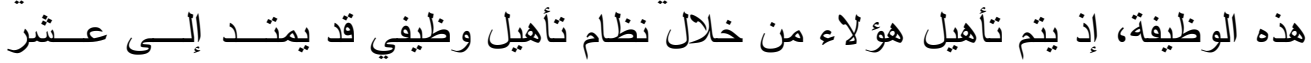

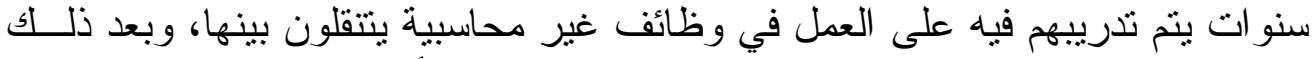

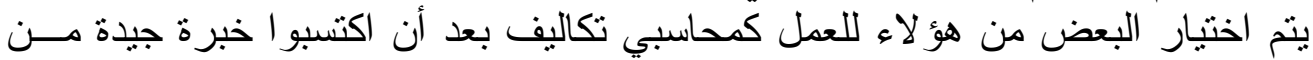
الأقسام التي عملو ا بها (Shields, et.al, 1991, 72).

ت. قياس المنفعة للأدوات الحديثة

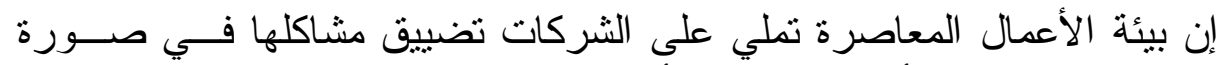

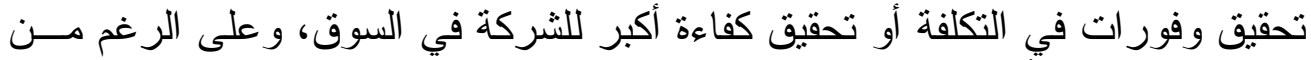

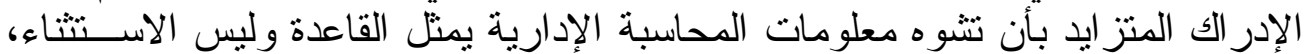

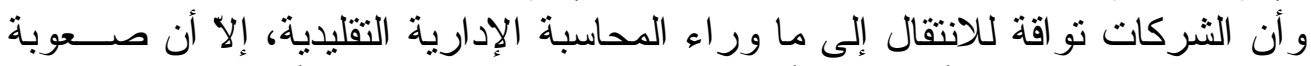

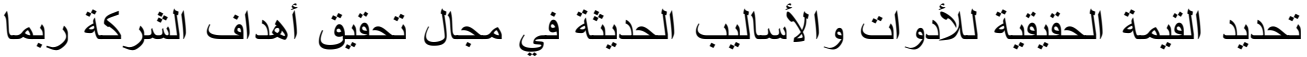

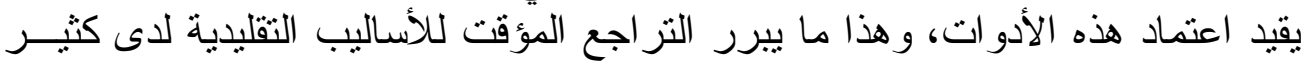
من الثركات (Garg, et.al, 2003, 32) .

ث. بحوث المحاسبة الإدارية

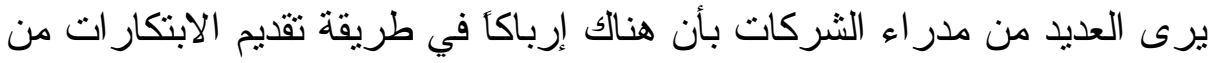

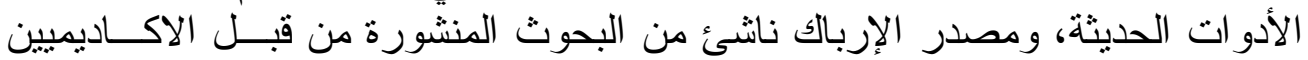
و المنظمات المختصة في المحاسبة الإدارية، إذ يحاول كل منهم تقديم الأسلوب المبنكر 


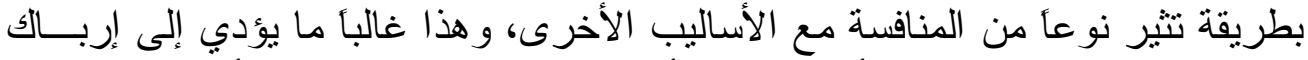

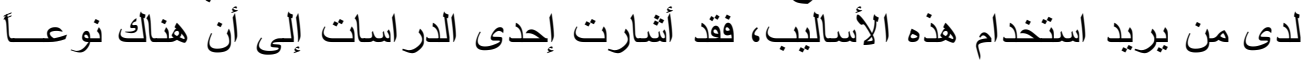

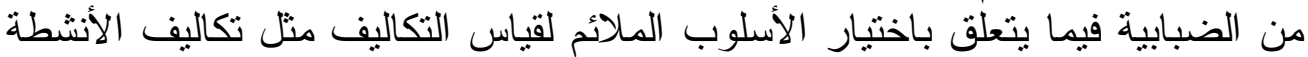

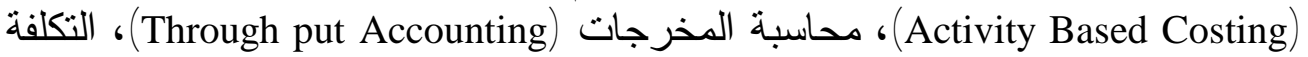

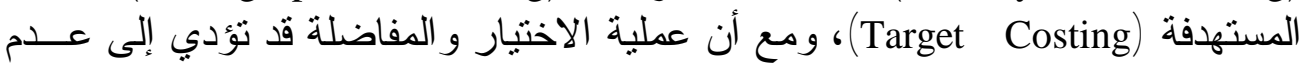

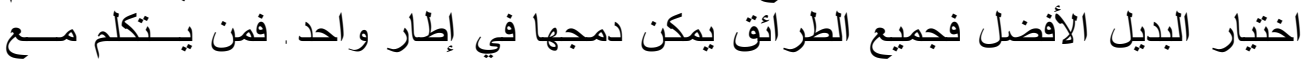

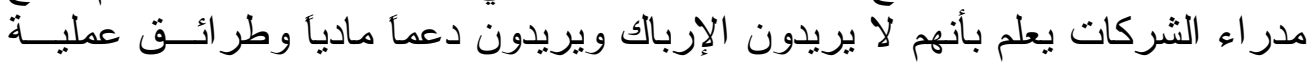
تساعدهم في صنع أفضل القرار ات (Cokins,2001,43).

\section{المحور الرابع: عرض نتائج الاستبانة وتحليلها}

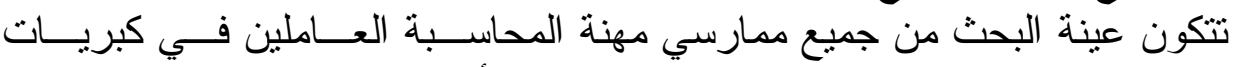
الثركات الصناعية في مدينة الموصل، إذ نم نوزيع الأستبانات بطريقة العينة العينة العشو ائية

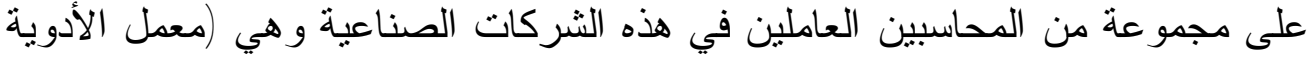

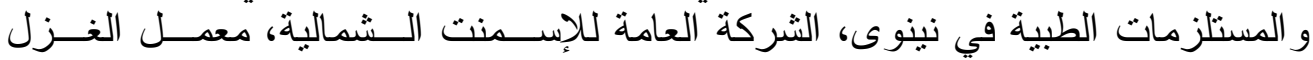

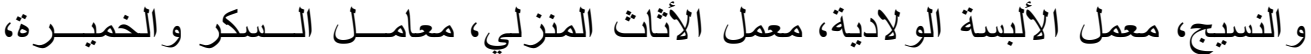

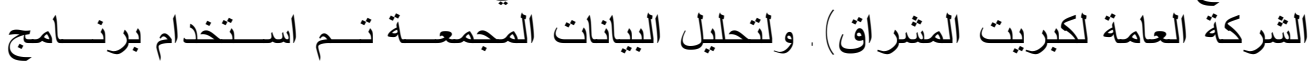
(Excel)

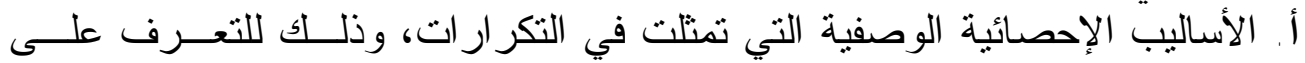
خصائص عينة البحث و التكرار الت النسية النسبية لبيان مقدار النسبة المئوية لكل فئة من

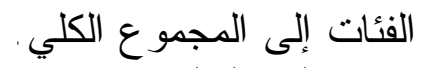

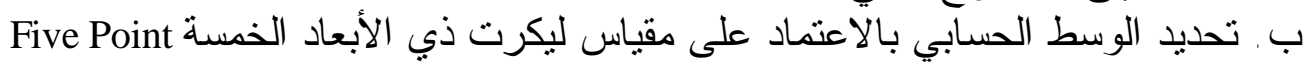

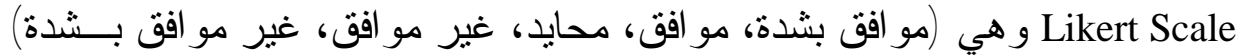

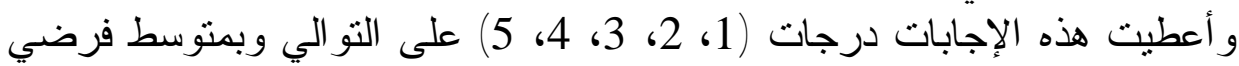

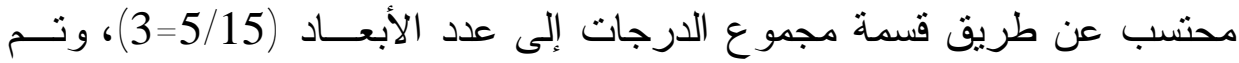

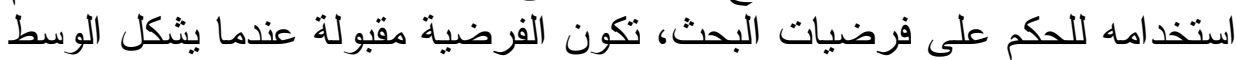

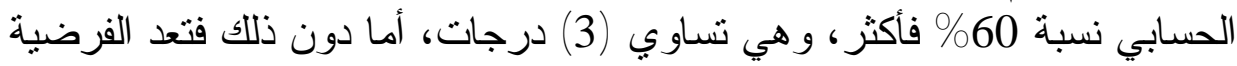
ت. الانحر اف المعياري وتم استخدامه من أجل التعرف على مقــدار التـشتـت فـي الإجابات حول الوسط الحسابي. 
أولاً - تحليل خصائص عينة البحث

\begin{tabular}{|c|c|c|c|c|c|}
\hline \multicolumn{6}{|c|}{ 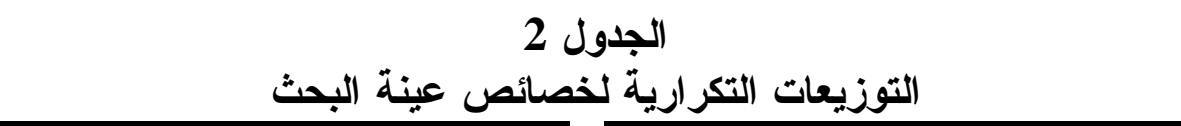 } \\
\hline$\%$ & التكرار & الاختصاص الدقيق & $\%$ & الت التكر ار & التحصيل العلمي \\
\hline 57.9 & 22 & محاسب مالي & 10.5 & 4 & إعدادية \\
\hline 0 & 0 & محاسب إداري & 26.3 & 10 & دبلوم \\
\hline 23.7 & 9 & محاسب تكاليف & 63.2 & 24 & بكالوريوس \\
\hline 18.4 & 7 & مدقق حسابات & 0 & 0 & شهادة عليا \\
\hline$\% 100$ & 38 & المجموع & $\% 100$ & 38 & المجموع \\
\hline$\%$ & التكر ار & عدد سنوات الخبرة & $\%$ & التكر ار & الارجة الوظيفية \\
\hline 23.7 & 9 & 1 - 5 سنة & 21.1 & 8 & معاون محاسب \\
\hline 23.7 & 9 & 10- 5 & 26.3 & 10 & محاسب \\
\hline 18.4 & 7 & $15-10$ & 15.8 & 6 & محاسب أقدم \\
\hline 13.1 & 5 & 20- 15 & 36.8 & 14 & مدير حسابات \\
\hline 21.1 & 8 & 20 - سنة فأكثر & $\% 100$ & 38 & المجموع \\
\hline$\% 100$ & 38 & المجموع & & & \\
\hline
\end{tabular}

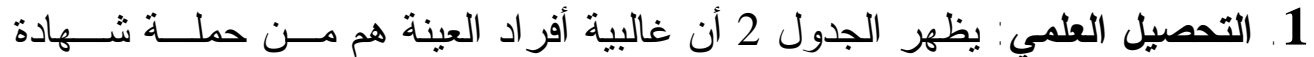

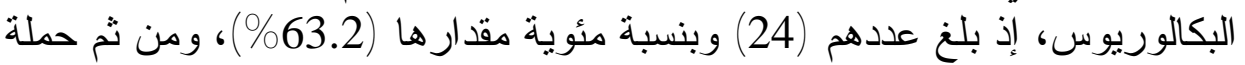

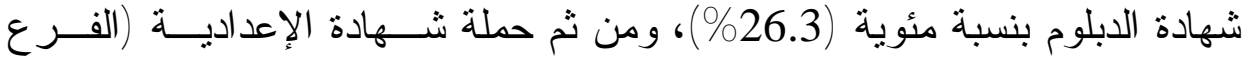

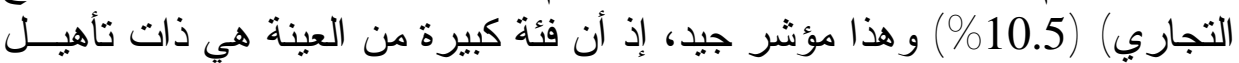

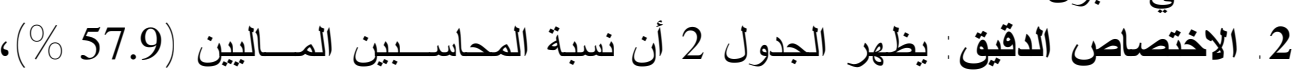

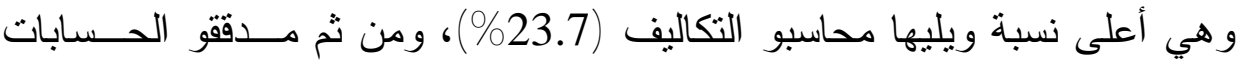

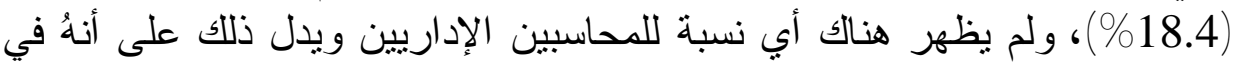

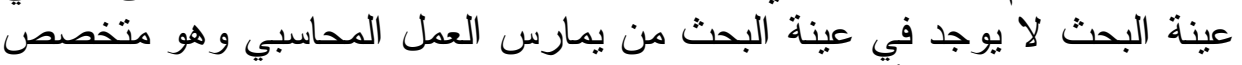

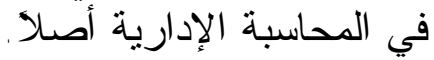




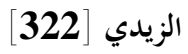

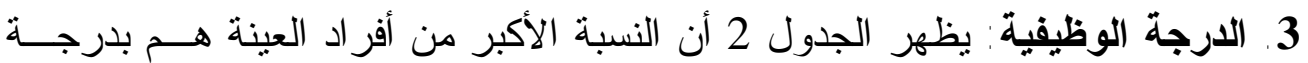

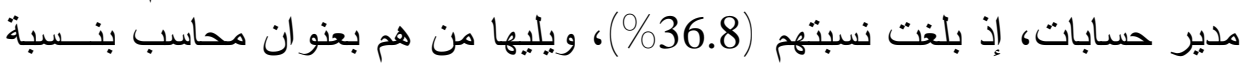

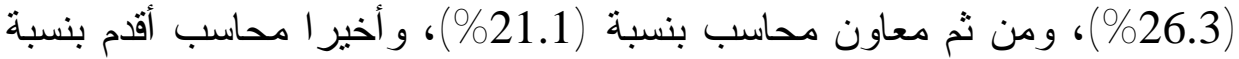
. (\% 15.8)

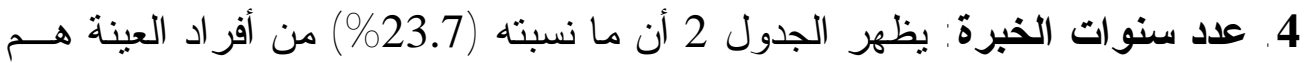

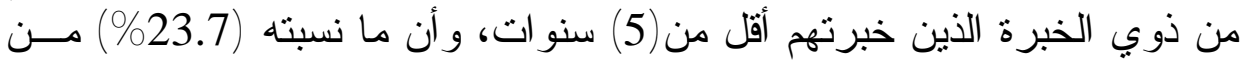

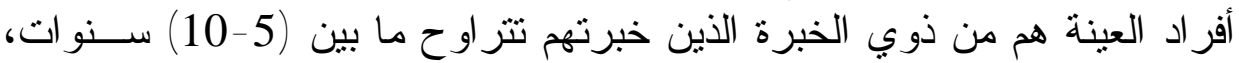

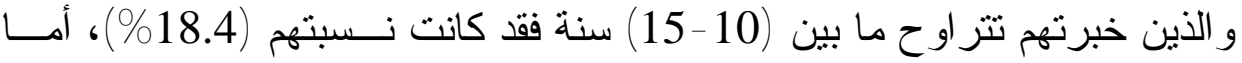

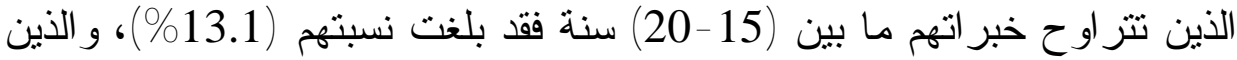

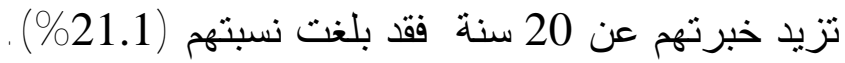

ثثانياً - التحديات المرتبطة بتطبيق الأساليب الحديثة في المحاسبة الإدارية

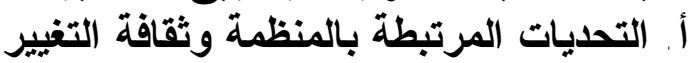

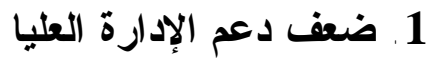

تم قياس هذا المتغير من خلال الأسئلة المبينة في الجدول 3 وذللك بإيجاد كل من الوسط الحسابي و الانحر اف المعياري لإجابات أفر اد عينة البحث وكالآتي:

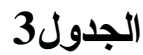

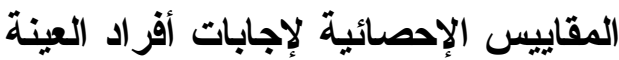

حول التحديات المتعلقة بلدع الإدارة العليا لتطبيق الأساليب الحديثة الإبية

\begin{tabular}{|c|c|c|c|c|c|c|c|c|c|c|c|c|}
\hline \multirow{2}{*}{ 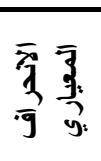 } & \multirow{2}{*}{ الحسابي } & \multicolumn{2}{|c|}{ غير موافق } & \multicolumn{2}{|c|}{ غير موافق } & \multicolumn{2}{|c|}{ محايد } & \multicolumn{2}{|c|}{ مو افق } & \multicolumn{2}{|c|}{ موافق بثدة } & /لإجابة \\
\hline & & $\%$ & عدد & $\%$ & عدد & $\%$ & عدد & $\%$ & عدد & $\%$ & عدد & 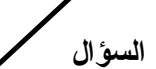 \\
\hline 0.963 & 3.421 & 0 & 0 & 23.7 & 9 & 21 & 8 & 44.8 & 17 & 10.5 & 4 & 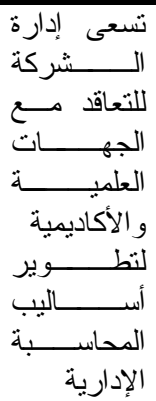 \\
\hline 0.993 & 3.526 & 0 & 0 & 26.7 & 9 & 13.15 & 5 & 50 & 19 & 13.15 & 5 & الــــــــر إدركة \\
\hline
\end{tabular}




\begin{tabular}{|c|c|c|c|c|c|c|c|c|c|c|c|c|}
\hline \multirow{2}{*}{$\begin{array}{l}\bar{y} \\
\bar{y} \\
\bar{y}\end{array}$} & \multirow{2}{*}{ الحسابي } & \multicolumn{2}{|c|}{ غير مو افقى } & \multicolumn{2}{|c|}{ غير موافق } & \multicolumn{2}{|c|}{ محايد } & \multicolumn{2}{|c|}{ مو افق } & \multicolumn{2}{|c|}{ موافق بثدة } & / الإجابة / مقياس \\
\hline & & $\%$ & عدد & $\%$ & عدد & $\%$ & عدد & $\%$ & عدد & $\%$ & عدد & السؤال \\
\hline & & & & & & & & & & & & 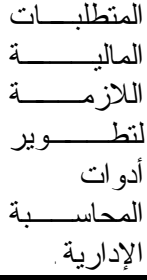 \\
\hline 1.024 & 3.052 & 7.9 & 3 & 21.1 & 8 & 34.2 & 13 & 31.6 & 12 & 5.2 & 2 & 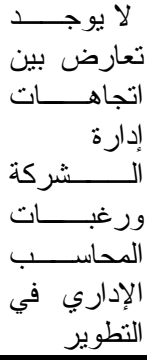 \\
\hline 0.992 & 3.552 & 0 & 0 & 18.4 & 7 & 26.4 & 10 & 36.8 & 14 & 18.4 & 7 & 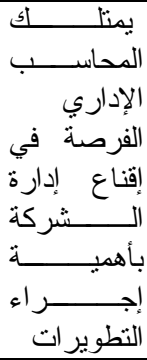 \\
\hline 0.781 & 3.368 & 2.6 & 1 & 13.1 & 5 & 31.7 & 12 & 47.3 & 18 & 5.3 & 2 & 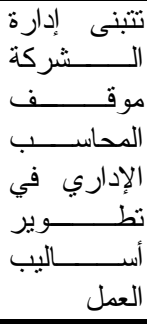 \\
\hline 0.968 & 3.384 & & & & & & & & & & & العنوسط \\
\hline
\end{tabular}

يبين الجدول 3 التحديات المتعلقة بدعم الإدارة العليا لتطبيق الأساليب الحديثــة طبقأ لمنوسطها الحسابي، كما يبين أيضاً نسبة المستجيبين تحت كل درجة من درجات الإن 
الزيدي [324

المو افقة على هذه التحديات، فضلا عن الانحر اف المعياري للإجابات لكل تحدٍ علـى حدة.

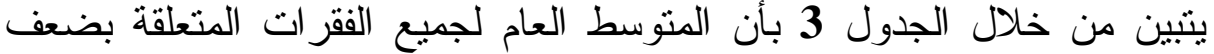

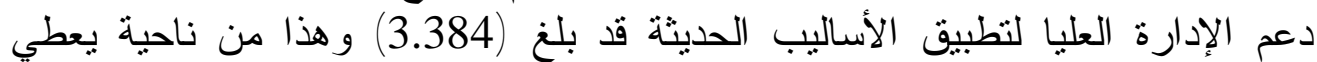

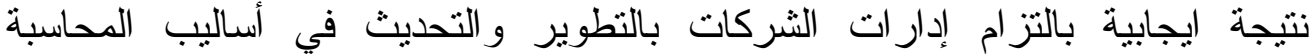

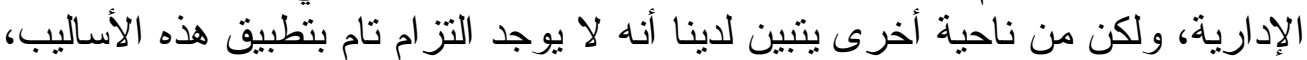

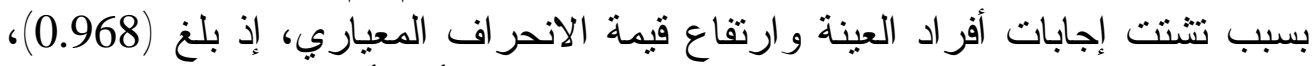

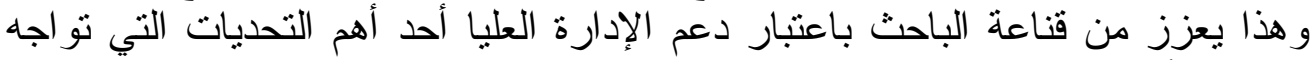
تطبيق الأساليب الحديثة.

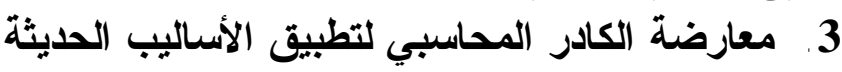

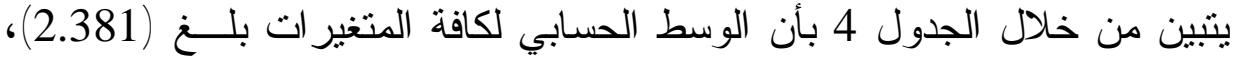

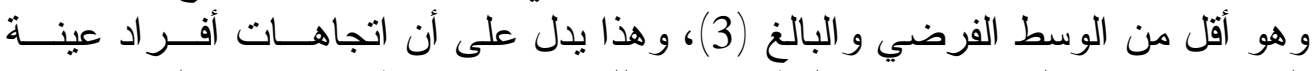

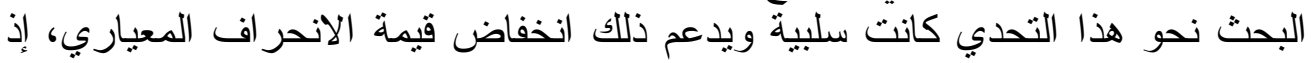

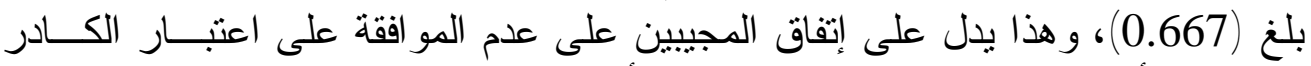

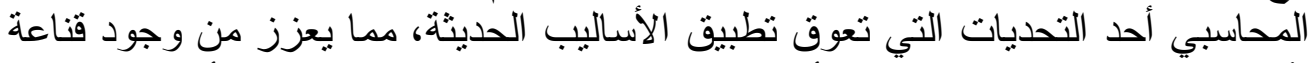
بأن المحاسبين ير غبون بتطوير أدو اتهم بالثكل الذي يحقق لهم مساهمة أكبر في إدارة

\begin{tabular}{|c|c|c|c|c|c|c|c|c|c|c|c|c|}
\hline & & & يوين & فرادر & خة & دول & $\sqrt{2}$ & ـ الإلإ & $\mathbf{2}$ & & & \\
\hline \multirow[t]{2}{*}{ المعياري } & \multirow[t]{2}{*}{ الحسابي } & \multicolumn{2}{|c|}{ مو غيّت } & \multicolumn{2}{|c|}{ غير موافق } & \multicolumn{2}{|c|}{ محايد } & \multicolumn{2}{|c|}{ مو افق } & \multicolumn{2}{|c|}{ مو افقدة } & \\
\hline & & $\%$ & عدد & $\%$ & عدد & $\overline{\%}$ & عدد & $\%$ & عدد & $\%$ & عدد & السؤال \\
\hline 0.708 & 2.394 & 5.3 & 2 & 57.9 & 22 & 28.9 & 11 & 7.9 & 3 & 0 & 0 & الطية معاسبي الحبدي الحالي \\
\hline 0.624 & 2.368 & 5.2 & 2 & 55.2 & 21 & 36.9 & 14 & 2.7 & 1 & 0 & 0 & 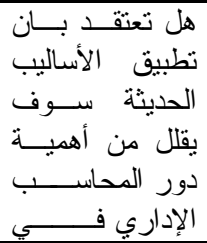 \\
\hline
\end{tabular}




\begin{tabular}{|l|l|l|l|l|l|l|l|l|l|l|l|l|}
\hline & & & & & & & & & & & & \\
\hline 0.667 & 2.381 & & & & & & & & & & & الثركة العنو \\
\hline
\end{tabular}

3. عدم تعاون المستويات الأخرى في تطبيق الأساليب الحديثة

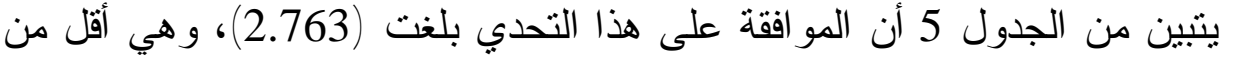

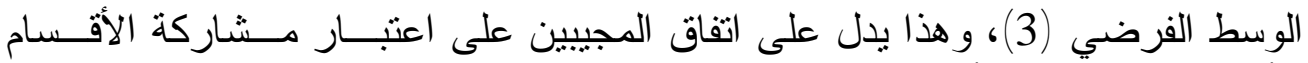

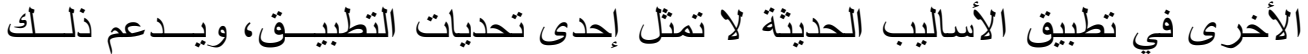

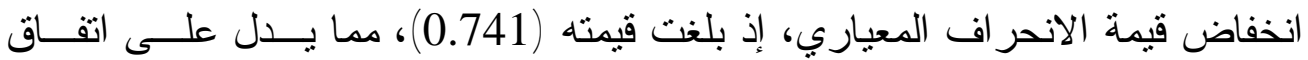

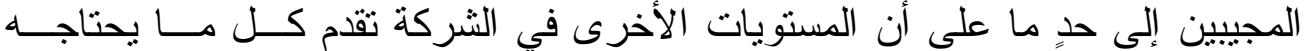
المحاسب الإداري أو محاسب التكاليف من معلومات تسهم في تطوير أساليب العمل.

\section{الجدول 5}

المقاييس الإحصائية لإجابات أفراد المئول العينة حول

التحديات المتعلقة بمشاركة المستويات الأخرى في تطبيق الأساليب الحديثة الإيثة

\begin{tabular}{|c|c|c|c|c|c|c|c|c|c|c|c|c|}
\hline \multirow{2}{*}{ المعياري } & \multirow{2}{*}{ الحسابط } & \multicolumn{2}{|c|}{ غير مو افق } & \multicolumn{2}{|c|}{ غير موافق } & \multicolumn{2}{|c|}{ محايد } & \multicolumn{2}{|c|}{ مو افق } & \multicolumn{2}{|c|}{ بثودة } & مقيا \\
\hline & & $\%$ & عدد & $\%$ & عدد & $\%$ & عدد & $\%$ & عدد & $\%$ & عدد & السؤوآل \\
\hline 0.741 & 2.763 & 2.6 & 1 & 34.3 & 13 & 47.3 & 18 & 15.8 & 6 & 0 & 0 & 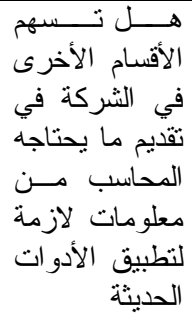 \\
\hline 0.741 & 2.763 & & & & & & & & & & & المتوسط العام \\
\hline
\end{tabular}

إن إجابات أفر اد عينة البحث عن هذا المحور تؤكد أن ثقافة التغيير بمسستوياتها

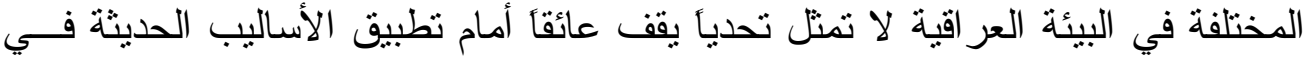

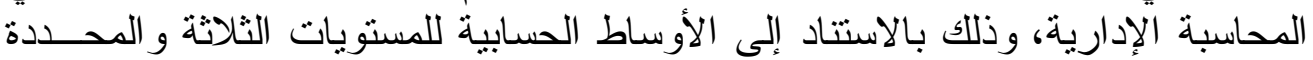

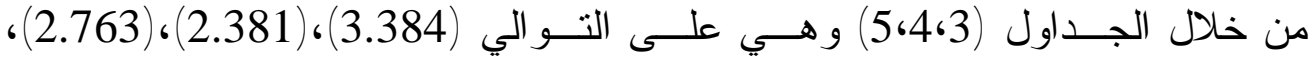

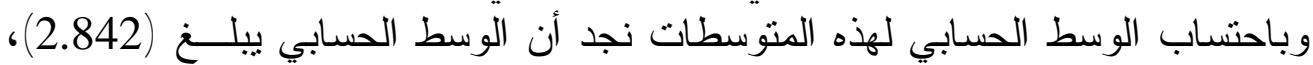

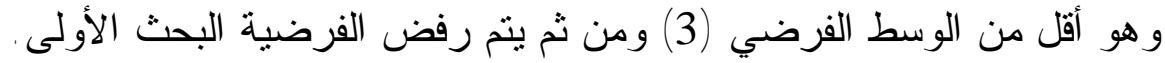


[326] الزيدي [3

ب. التحديات المتعلقة بقلة الخبرة ونقص الكادر المدرب

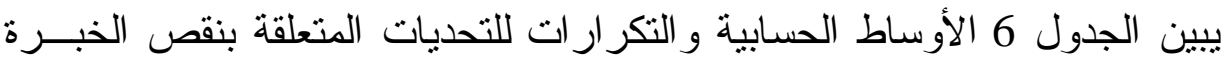

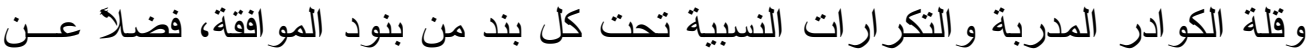
الانحر افات المعيارية لكل تحدٍ على حدة.

\begin{tabular}{|c|c|c|c|c|c|c|c|c|c|c|c|c|}
\hline & & كرب & 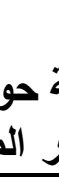 & () & رنق & 10 & ائيً & كقا & يبير اله & تحديا & & \\
\hline الاتحراف & الوسط & إفق & غير بث & & & & & فق & & بثدة & & $\omega$ \\
\hline المعياري & الحسابي & $\%$ & عدد & $\%$ & عدد & $\%$ & عدد & $\%$ & عدد & $\%$ & عدد & \\
\hline 0.613 & 3.789 & 0 & 0 & 5.2 & 2 & 15.9 & 6 & 73.7 & 28 & 5.2 & 2 & 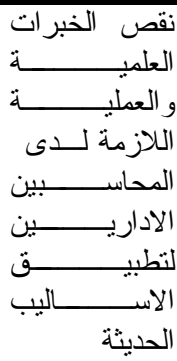 \\
\hline 0.929 & 3.631 & 2.6 & 1 & 13.1 & 5 & 13.1 & 5 & 60.7 & 23 & 10.5 & 4 & 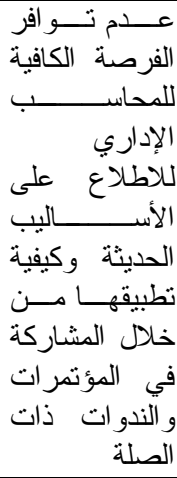 \\
\hline 0.855 & 3.710 & 0 & 0 & 13.1 & 5 & 15.9 & 6 & 57.9 & 22 & 13.1 & 5 & 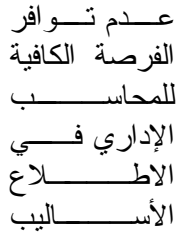 \\
\hline
\end{tabular}




\begin{tabular}{|c|c|c|c|c|c|c|c|c|c|c|c|c|}
\hline \multirow{2}{*}{ المعياري } & \multirow{2}{*}{ الحسابي } & \multicolumn{2}{|c|}{ غير مو افقى } & \multicolumn{2}{|c|}{ غير موافق } & \multicolumn{2}{|c|}{ محايد } & \multicolumn{2}{|c|}{ موافق } & \multicolumn{2}{|c|}{ موافق بشدة } & (1) \\
\hline & & $\%$ & عدد & $\%$ & عدد & $\%$ & عدد & $\%$ & عدد & $\%$ & عدد & السؤال \\
\hline & & & & & & & & & & & & 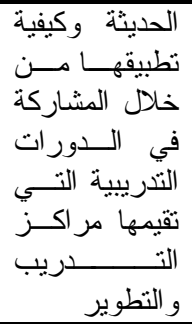 \\
\hline 0.907 & 3.578 & 2.6 & 1 & 7.9 & 3 & 31.6 & 12 & 44.9 & 17 & 13.1 & 5 & 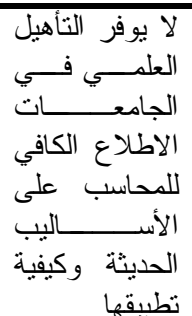 \\
\hline 0.723 & 3.947 & 0 & 0 & 5.2 & 2 & 13.1 & 5 & 63.2 & 24 & 18.5 & 7 & 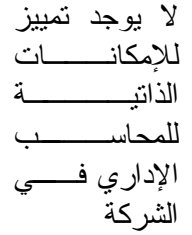 \\
\hline 0.805 & 3.731 & & & & & & & & & & & المتوسط العام \\
\hline
\end{tabular}

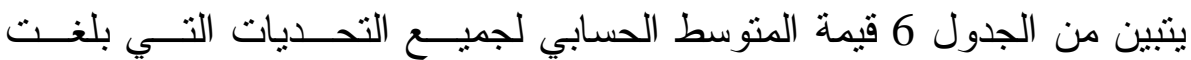

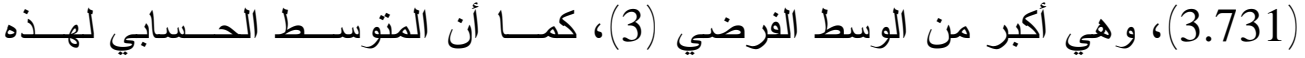

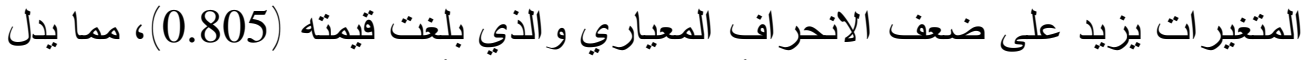

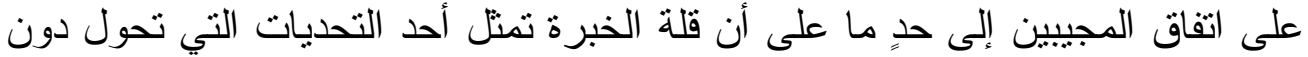

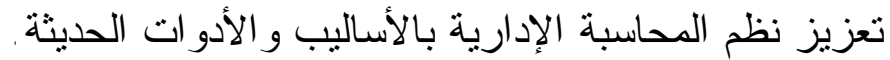

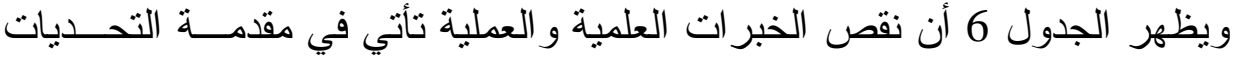

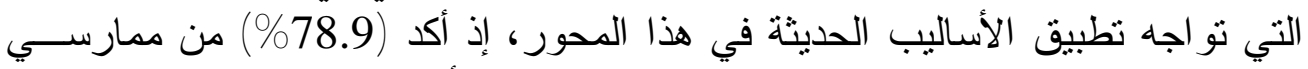

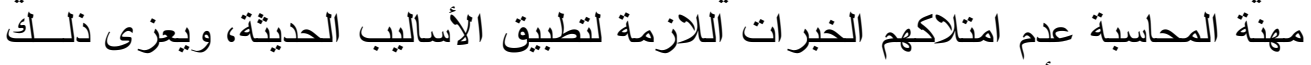

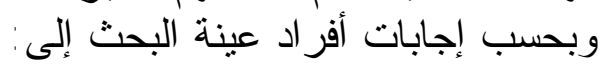

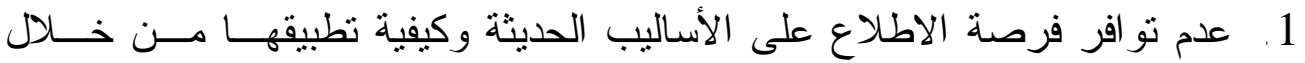
المشاركة في المؤتمر ات والندو ات ذات الصلة، إذ أكد (71.2\%) من أفر اد العينة 


\section{الزيدي [328]}

على أهمية هذا التحدي، وبلغت درجة المو افقة عليه (3.631) وبانحر اف معياري

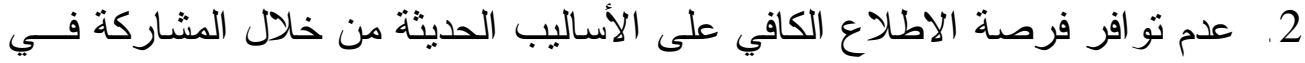

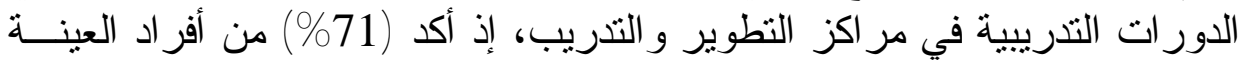

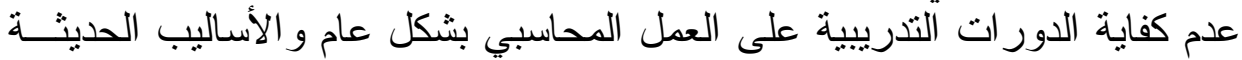

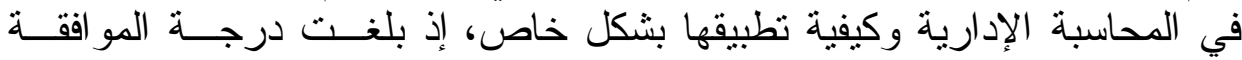

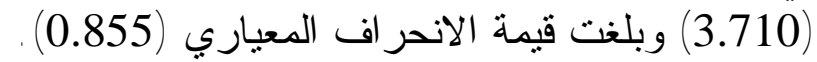

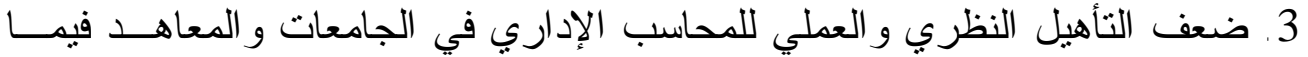

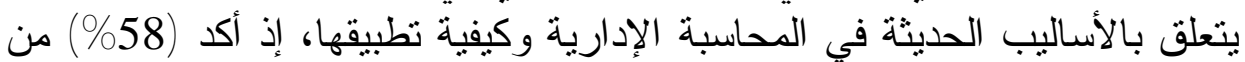

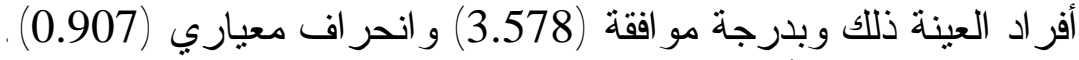

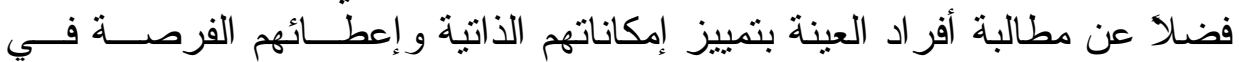

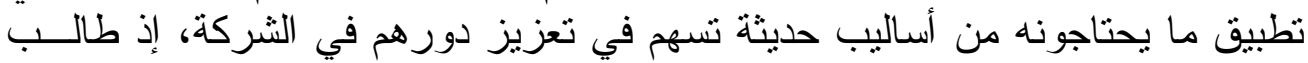

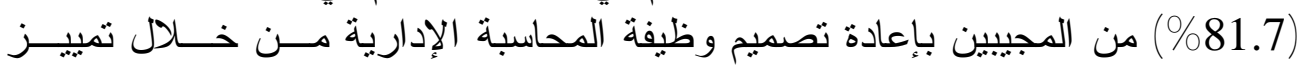
الإمكانات الذاتية للمحاسبين، ولعل أحد أسباب ذلاعن أن أن هناك الكثير من الذين الذين يمارسون

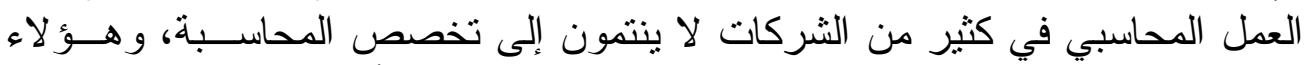

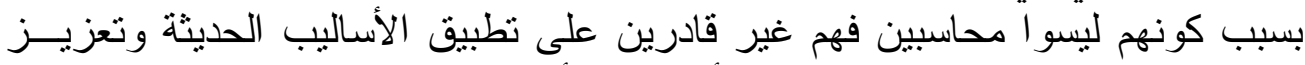
نظم المحاسبة الإدارية في شركاتهم بالأدو ات و الأساليب الحديثة فئنة

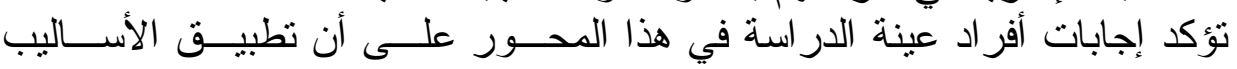

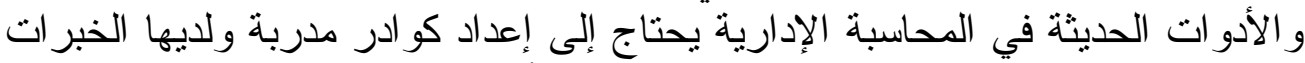

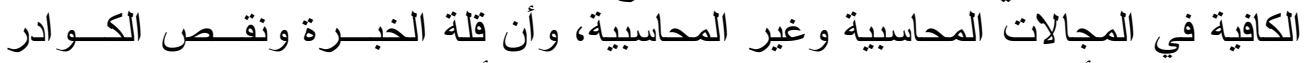

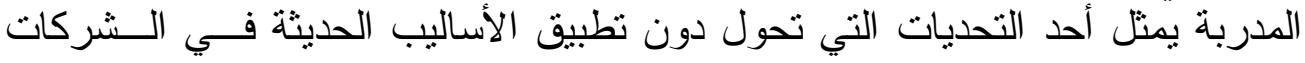
العر اقية وهذا ما يثبت فرضية الَّبث البحت الثانية.

ت. التحديات المتعلقة بقياس المنفعة للأدوات الحديثة

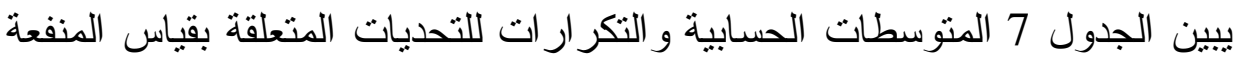

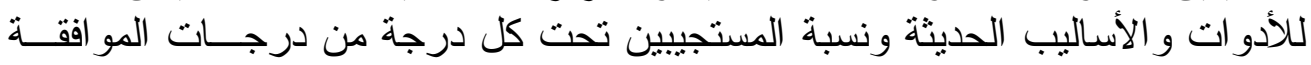

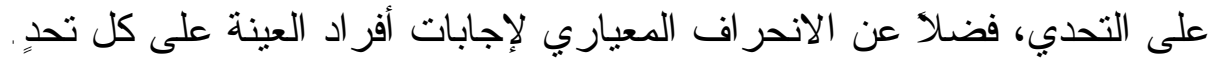

\section{الجدول 7}

المقاييس الإحصائية لإجابات أفراد العينة حول

التحديات المتعلقة بقياس الإندائة لإبات المنفة للأدوات العديثة حولة 


\begin{tabular}{|c|c|c|c|c|c|c|c|c|c|c|c|c|}
\hline \multirow{2}{*}{$\frac{\bar{y}}{\bar{y}} \stackrel{\overline{3}}{9}$} & \multirow[t]{2}{*}{ الحسابي } & \multicolumn{2}{|c|}{ مو غير بشد } & \multicolumn{2}{|c|}{ غير موافق } & \multicolumn{2}{|c|}{ محايل } & \multicolumn{2}{|c|}{ موافق } & \multicolumn{2}{|c|}{ موافق بشدة } & \multirow[b]{2}{*}{ السؤ ال } \\
\hline & & $\%$ & عدد & $\%$ & عدد & $\%$ & عدد & $\%$ & عدد & $\%$ & عدد & \\
\hline 0.739 & 4.078 & 0 & 0 & 2.6 & 1 & 15.8 & 6 & 52.6 & 20 & 29 & 11 & 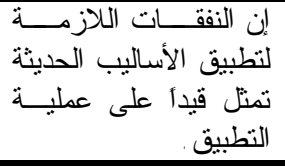 \\
\hline 0.664 & 3.921 & 0 & 0 & 2.6 & 1 & 18.4 & 7 & 63.2 & 24 & 15.8 & 6 & أنشاط الطبيق ما يتلاءه من الألتصادية \\
\hline 0.753 & 4.105 & 0 & 0 & 5.2 & 2 & 7.9 & 3 & 57.9 & 22 & 29 & 11 & تصميم وظيفة الإلكاسبة الإعـادة \\
\hline 0.655 & 4.21 & 0 & 0 & 2.6 & 1 & 5.2 & 2 & 60.7 & 23 & 31.5 & 12 & 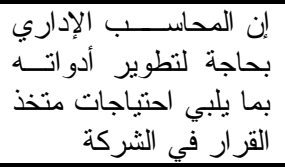 \\
\hline 0.703 & 4.078 & & & & & & & & & & & المنوسط العام \\
\hline
\end{tabular}

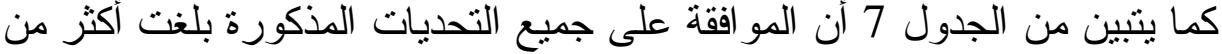

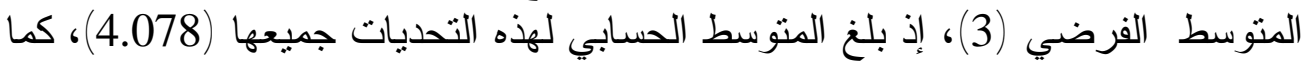
بلغت قيمة الانحر اف المعياري (303)، (30.703، مما بدل على قلة تباين الآراء حول المو افقة على هذه التحديات . ويبين الجدول 7 أيضاً، أن القيمة التي سوف تضيفها الأساليب الحديثة قد تبــرر

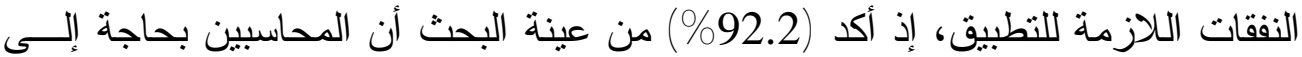

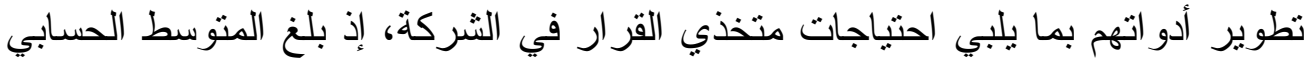

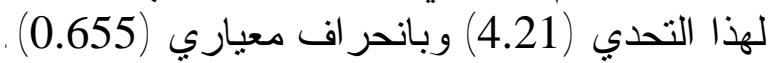

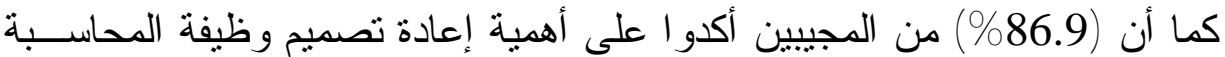

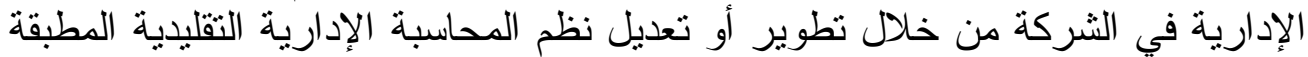

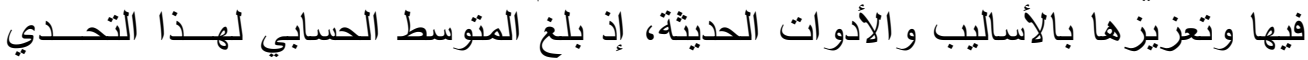
جميعها (4.105) وبانحر اف معياري (0.753) . 
[330] الزيدي

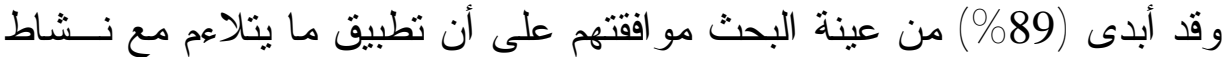

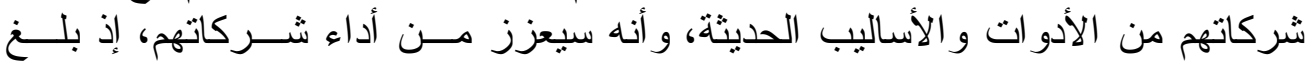

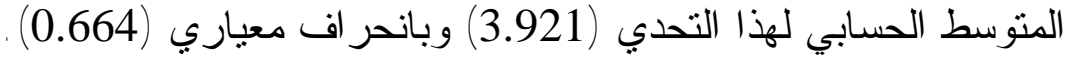

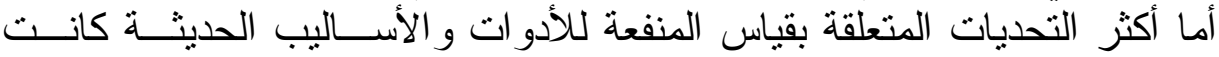

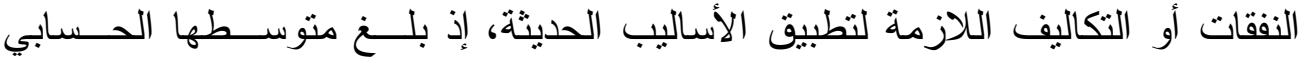

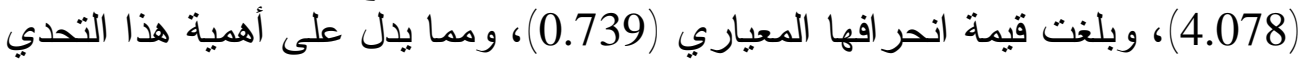

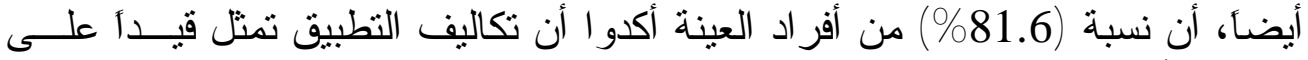
تطبيق الأساليب الحديثة.

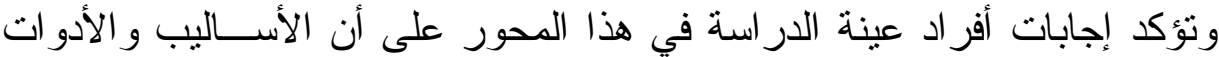

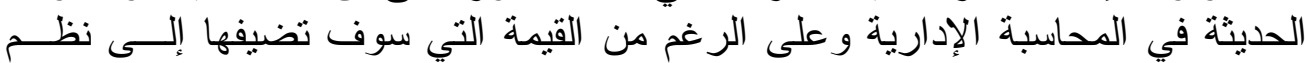

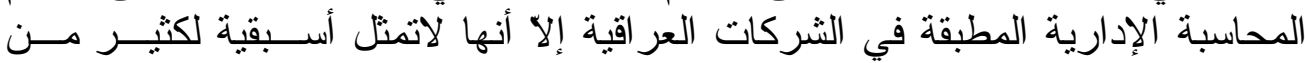

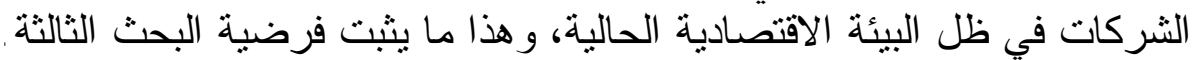

ث. التحديات المتعلقة بملاعمة بحوث المحاسبة الإدارية

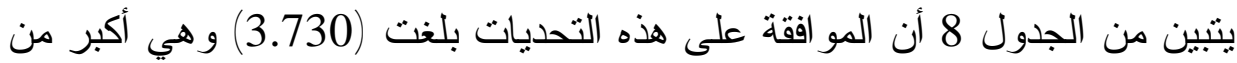

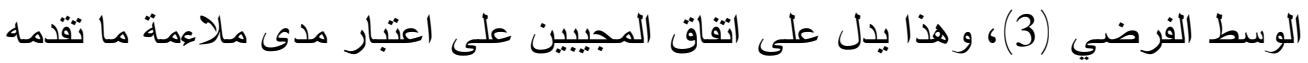

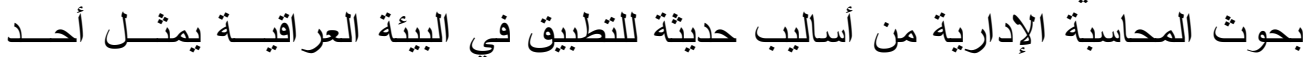

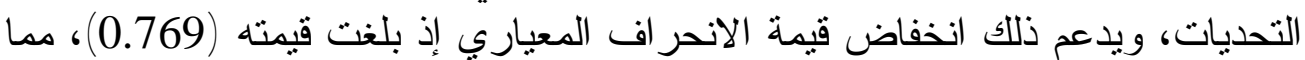
يدل على اتفاق المجييين إلى حلٍٍ ما على هذا التحدي. التحدي.

\section{الجدول 8}

المقاييس الإحصائية لإجابات أفر اد العينة حول

التحديات المتعلقة بملاعمة بحوث الإبات المحاسبة الإدارية حرلة

\begin{tabular}{|c|c|c|c|c|c|c|c|c|c|c|c|c|}
\hline \multirow[t]{2}{*}{ الالمعياري } & \multirow[t]{2}{*}{ الحسابي } & \multicolumn{2}{|c|}{ موافقي } & \multicolumn{2}{|c|}{ غير موافق } & \multicolumn{2}{|c|}{ محايد } & \multicolumn{2}{|c|}{ موافق } & \multicolumn{2}{|c|}{ موافق بثدة } & \multirow{2}{*}{ السؤل /لقيس الإجابة } \\
\hline & & $\%$ & عدد & $\%$ & عدد & $\%$ & عدل. & $\%$ & عدد & $\%$ & عال & \\
\hline 0.815 & 3.578 & 0 & 0 & 13.1 & 5 & 23.7 & 9 & 55.2 & 21 & 7.9 & 3 & 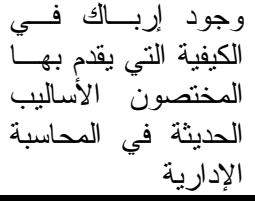 \\
\hline 0.815 & 3.578 & 0 & 0 & 13.1 & 5 & 23.7 & 9 & 55.2 & 21 & 7.9 & 3 & 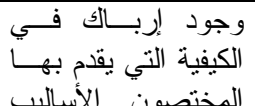 \\
\hline
\end{tabular}




\begin{tabular}{|c|c|c|c|c|c|c|c|c|c|c|c|c|}
\hline \multirow[t]{2}{*}{ الالحيراف } & \multirow[t]{2}{*}{ الوسابط } & \multicolumn{2}{|c|}{ بشئ بوافي } & \multicolumn{2}{|c|}{ غير موافق } & \multicolumn{2}{|c|}{ محايد } & \multicolumn{2}{|c|}{ موافق } & \multicolumn{2}{|c|}{ موافق بشدة } & \multirow[b]{2}{*}{ السؤال } \\
\hline & & $\%$ & عدد & $\%$ & علد & $\%$ & عدد & $\%$ & عدد & $\%$ & عدد & \\
\hline & & & & & & & & & & & & الإدارية في المحاسبة \\
\hline 0.880 & 3.473 & 0 & 0 & 18.4 & 7 & 23.7 & 9 & 50 & 19 & 7.9 & 3 & 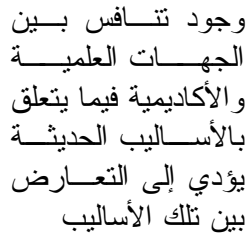 \\
\hline 0.870 & 3.921 & 0 & 0 & 10.5 & 4 & 10.5 & 4 & 55.3 & 21 & 23.7 & 9 & 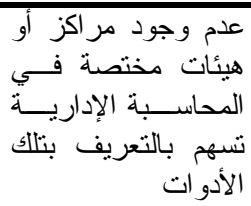 \\
\hline 0.510 & 3.947 & 0 & 0 & 2.6 & 1 & 7.9 & 3 & 81.6 & 31 & 7.9 & 3 & 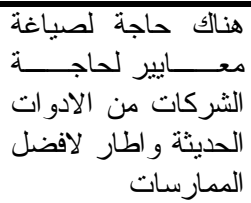 \\
\hline 0.769 & 3.730 & & & & & & & & & & & المتوسط العام \\
\hline
\end{tabular}

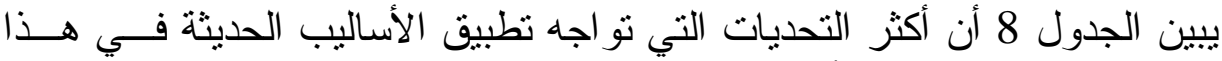

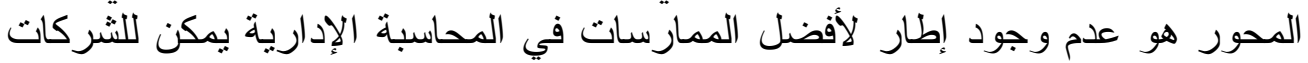
الاسترشاد به في تطوير نظم المحاسبة الإدارية المطبقة فيها، إذ أكد (88.5\%) مسنـن

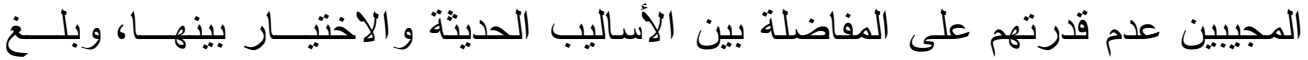

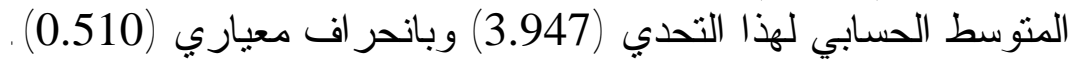

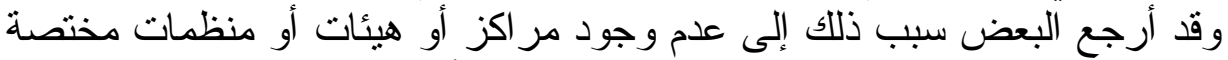
في المحاسبة الإدارية في العراق تسهم في التعريف بالأساليب الحديثة وكيفية تطبيقها

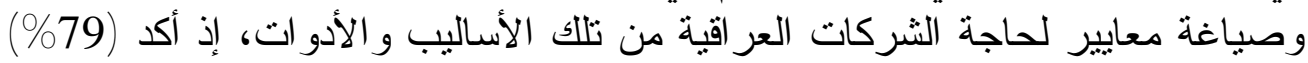

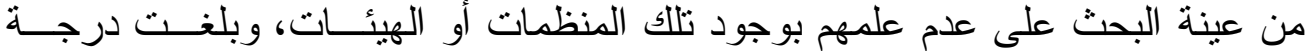

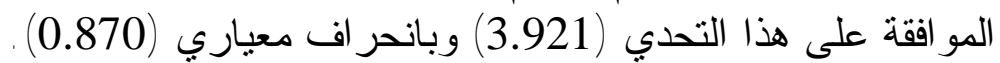
في حين أرجع البعض الآخر أسباب عدم التطبيق إلى الإربالك في طريقة تقـئديم

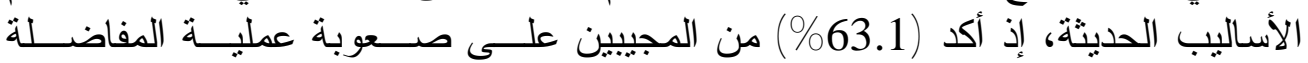

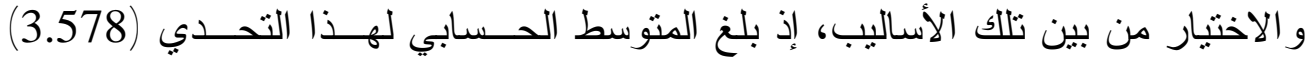
وبإنحر اف معياري (0.815) . 


\section{[332] [ الزيدي}

وقد أبدى (57.9\%) من المجيبين مو افقته على أن المنافسة بين الجهات العلمية

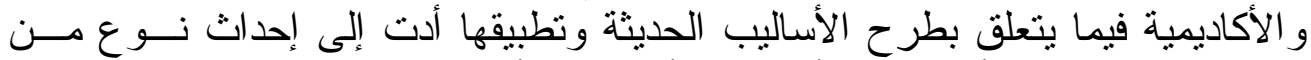

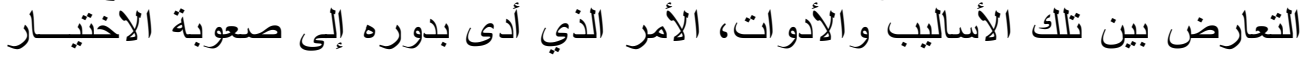
و المفاضلة بينها، وبلغت درجة المو افقة على هذا التحدي (3.473) وبانحر الإن الف معياري

تؤكد إجابات أفر اد عينة الدر اسة في هذا المحور أن عدم وجود مر اكز أو هيئات

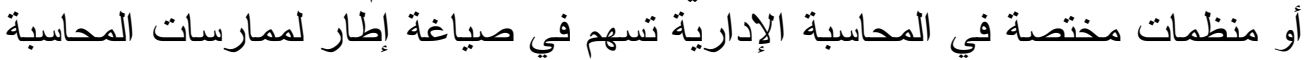

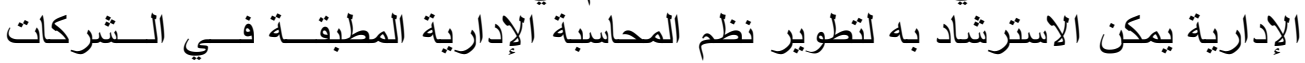

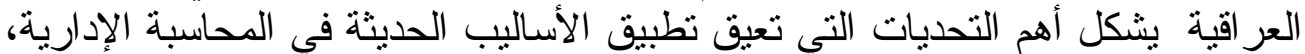

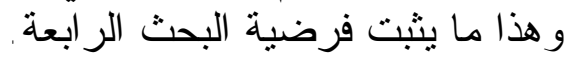

1. إن الأساليب الحديثة هي السمة المميزة لنطور المحاسبة الإدارية وهي نتاج لتنازم منطقي بين التهديدات و الفرص التي تو اجه المنظمات في بيئة الأعمال الحديثة.

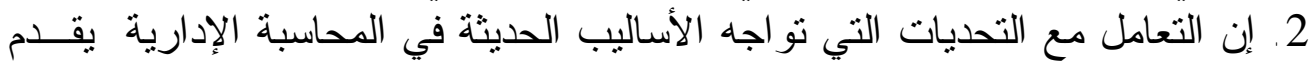

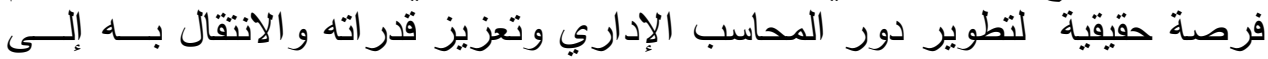

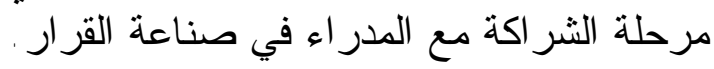
3. إن عدم نو افر الصدلاحيات للتوسع في إجر اءع التحاء التحديثات على نظم المحاسبة الإدارية و التقيد بالتعليمات أدى بالكثير من الثركات العر اقية إلى التأخر في تطبيق الأساليب الحديثة. 4. إن عدم وجود أقسام للمحاسبة الإدارية في الثركات العر اقية أدى إلى قيام الأقـسام

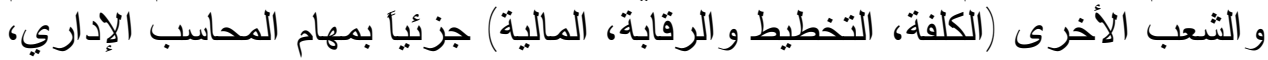
وقد أضاف ذلك تحدياً جديداً أمام تطبيق الأساليب الحديثة في النية المحاسبة الإدارية.

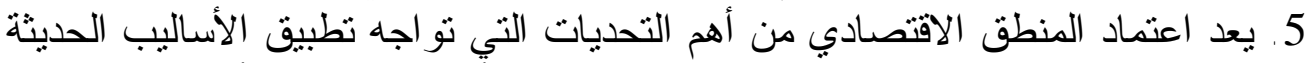

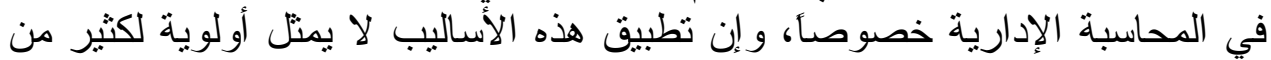

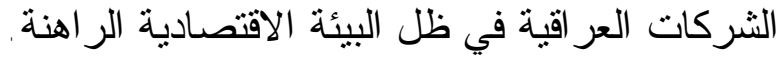

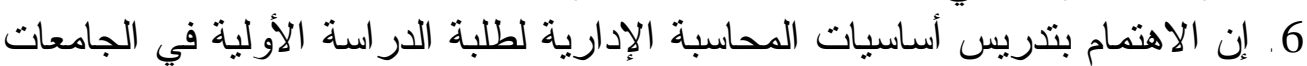

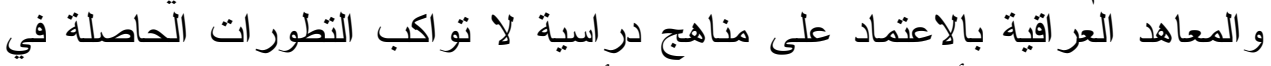

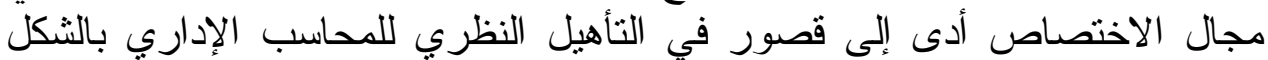
الذي أثز في قدرته على نطبيق الأساليب الحديثة. 
7.عدم مو اكبة ممارسي المهنة للمستجدات في المحاسبة الإدارية من خلال المشاركة

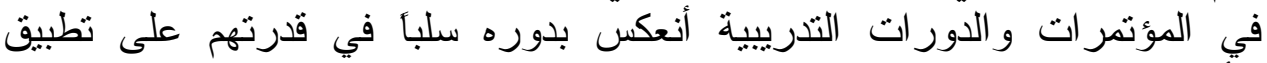
الآساليب الحديثة.

8. عدم وجود مر اكز أو هيئات أو منظمات عر اقية مختصة في المحاسبة الإدارية على الإئ

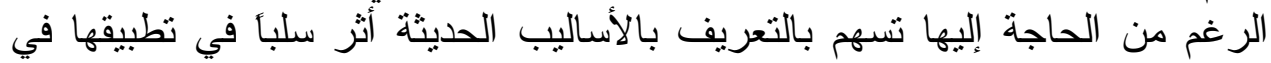

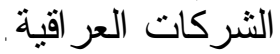

ثانياً - التوصيات

1. يؤكد البحث على نوعية المحاسبين الإداريين المطلوبين لبيئة الأعمال الحديثة فهر

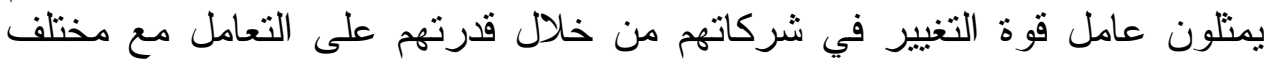

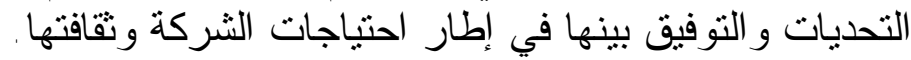

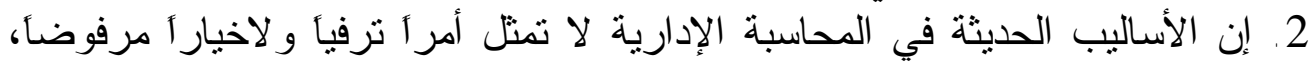

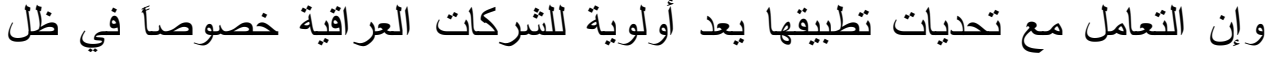

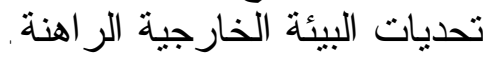
3. على الثركات العر اقية إعطاء اهتمام أكبر لوظيفة الرية المحاسبة الإدارية و إنثاء أقسام

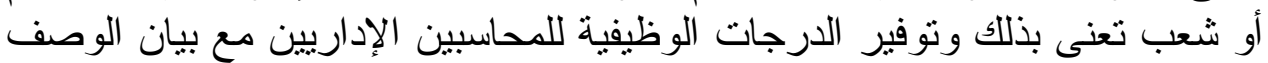

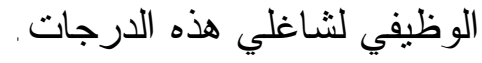
4. ضرورة قيام الجهات العلمية والأكاديمية بإعادة تقييم ممارسات المحاسبة الإدارية المطبقة في الثركات العر اقية وصياغة إطار مفاهيمي لأفضل ممارسات المحاسبة الإدارية.

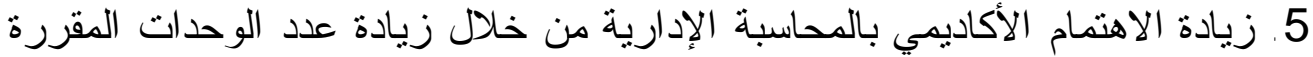

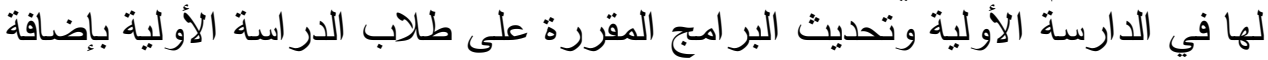

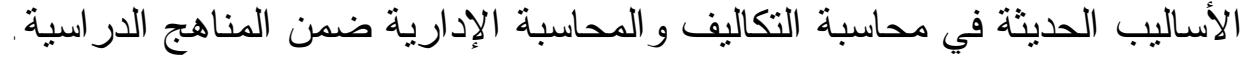

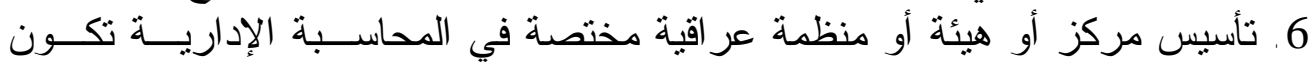

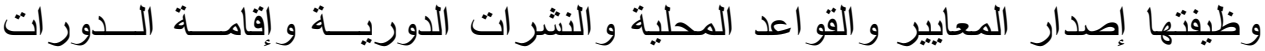

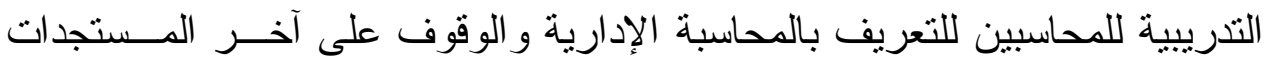

1. Atkinson. A, 1989, "A management accounting constitution", CMA Magazine, vol 63, No 5, JUNE.

2. Burns .J, 2000, " The changing nature of management accounting and the emergence of hybrid accountant", www.ifac.org/articals .

3. Cokins .G, 2001, " A management accounting framework", international Magazine of strategic cost management, vol 1 , No 2 . 


\section{الزيدي [334]}

4. Dminik .T, \& Kudar .R , 1989," Do not throw out the baby with the path water" , CMA Magazine, vol 63, No 6, JULY-AUGUST.

5. Garg .A, Ghosh .D, Hudik .J , Nowaki .C, 2003, "Roles and practices in management accounting today", strategic finance, JULY.

6. International Federation Of Accountants (IFAC), 1998, "Management accounting concepts (IMP 1)", Financial Management \& Management Accounting Committee(FMAC)), MARCH.

7. Kaplan .R.S, 1984," The evolution of management accounting", The Accounting Review, JULY. www.maaw.info.index/managementaccounting.

8. Luther .R , \& Abdel-kader . M, 2006, "Management accounting practices in the UK food industry", CIMA the chartered institute of management accounting, London .

9. Mai .A, Ahmed .F, 2005, "Strategic management accounting practices in the $21^{\text {st }}$ century", The Cost and Management Journal, vol 33, No 4.

10. Ning .Y, 2005, " The development of costing system: a historical perspective", Journal of modern accounting and auditing, vol 1, No 2.

11. Sharma .R, 2000, " From relevance lost to relevance regained : management accounting practices in the new millennium". www.ifac.org/artical

12. Shields .D, Chow .C , Kato .Y, Nakagaw .Y, 1991," Management accounting practices in the U.S and Japan" , Journal of international financial management and accounting, vol 3 , No 1.

13. Steeves .B, 1990, " Trends in management accounting", CMA Magazine, vol 64, No 3,MARCH.

14. www.esnips.com/search/costaccounting, "Basic Cost Concepts". 


\author{
التحديات التي تواجه تطبيق الأساليب الحديثة

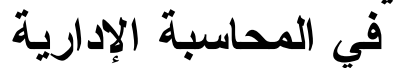 \\ دراسة لآراء عينةٌ من المحاسبين في مدينة الموصل$$
\text { مدرس مساعد- قسم المئمبة }
$$$$
\text { كلية الإدارة والاقتصاد- جامعة الموصل }
$$ \\ Muthanaalzaidy@yahoo.com
}

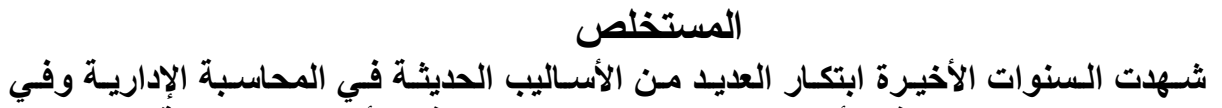

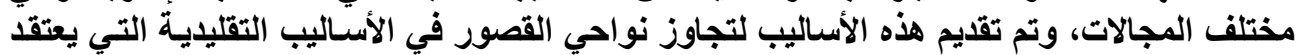

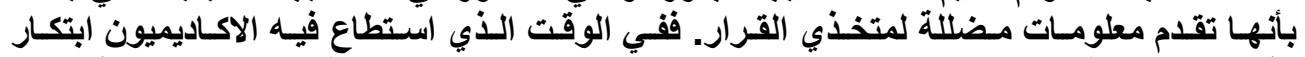

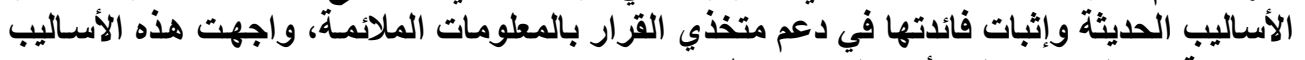

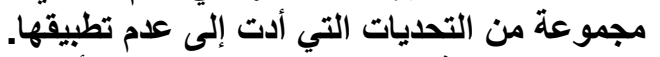

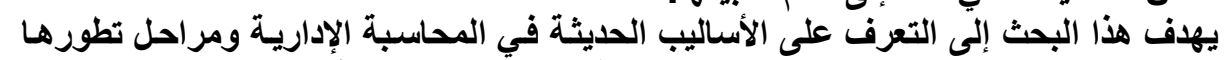

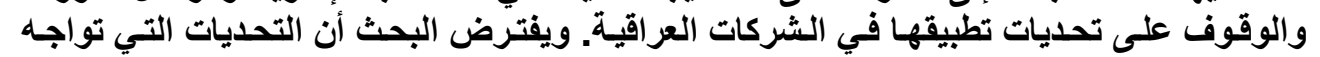

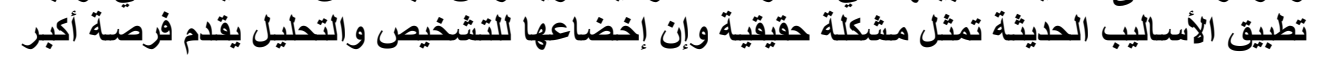

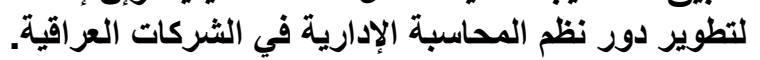

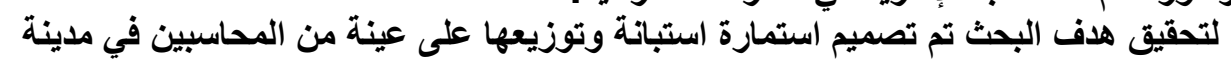

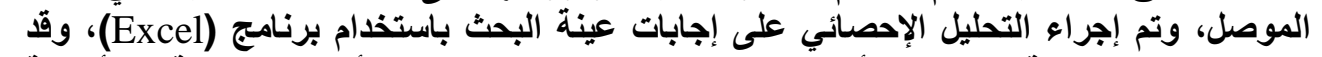

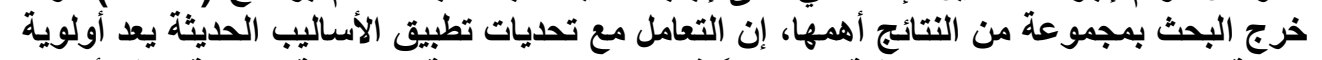

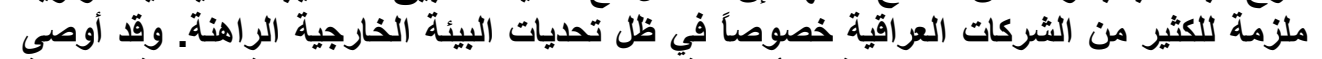

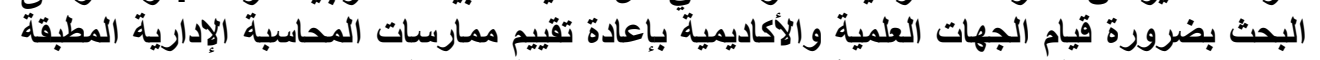

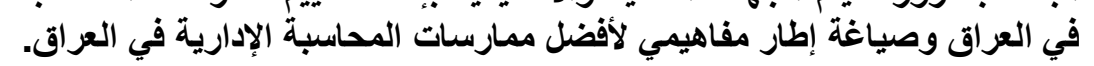

تأريخ قبول النشر 2008/12/23 تأريخ استلام البحث 2008/10/9 


\title{
The Challenges Facing the Application of Modern Management Accounting Techniques Studying for The Opinion a Sample of Accountants in the City of Mosul
}

\author{
Muthana F. Al-Zaidy \\ Assistant Lecturer \\ Collage of Administration and Economics \\ Muthanaalzaidy@yahoo.com
}

\begin{abstract}
The present research aims at identifying modern techniques of management accounting, showing the stages of their development and identifying the challenges that prevent their application in Iraqi companies. The research hypothesizes that these challenges represent a real problem, and make them subject of diagnostic analysis to provide a greater opportunity to develop the role of management accounting systems. To achieve the goal of the research, a survey form has been designed and distributed to a sample of accountants in the City of Mosul, and then statistical analysis of responses has been made to investigate the samples using (Excel). The basic conclusion of the research is to deal with the challenges of the application of modern techniques and binding to many Iraqi companies especially in the light of the challenges of the current external environment. The research recommended the need for the scientific and academic reevaluation of management accounting practices applied in Iraq and drafting a conceptual framework for a better management accounting practices.

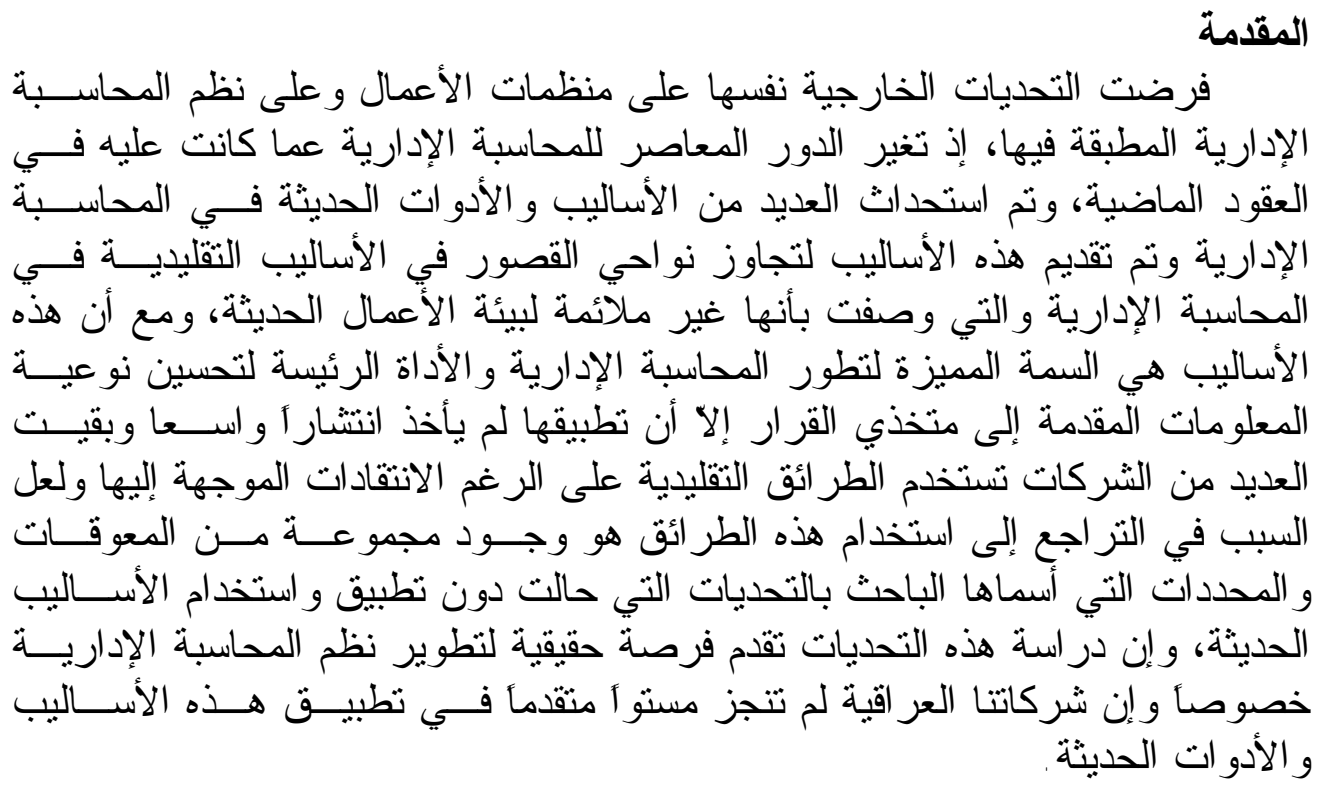


يمكن صياغة مشكلة البحث من خلال طرح التساؤ لات الآتية:

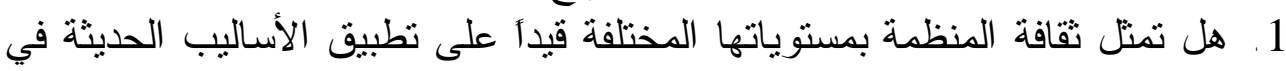
المحاسبة الإدارية في الثركات العر اقية؟

2. هل تتسجم الخبر ات العلمية و العملية التي يمتلكها المحاسب في الثركات العر اقية

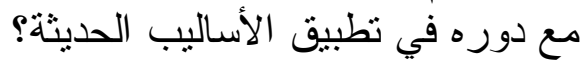
3. هل تبرر القيمة التي سوف تضيفها الأدوات و الأساليب الحديثة على أداء الثركات العر اقية النفقات اللازمة لتطبيقها؟ 4. هل تحتاج الثركات العر اقية إلى إطار مفاهيمي لممارسات المحاســبة الإداريــة

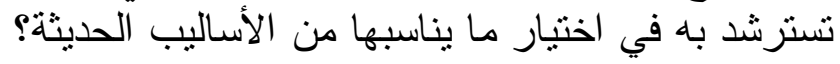

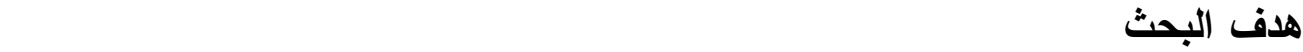
يهذف هذا البحث إلى التعرف على الأساليب الحديثة في المحاسـبـة الإداريــة

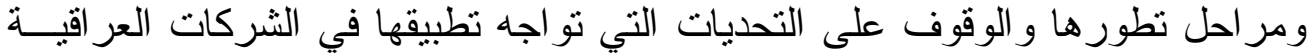
وبيان المسببات الحقيقية لها.

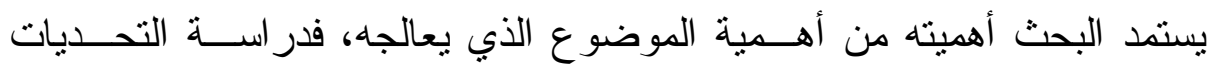

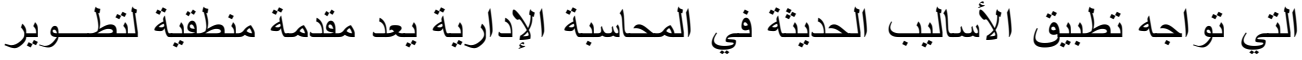

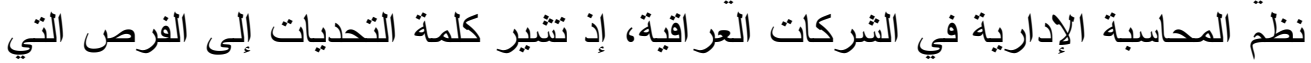
يمكن من خلالها تطوير نظم المحاسبة الإدارية، و الانتقال بها إلى مر احل متقدمة تسهر في تعزيز أداء الثركات العر اقية.

يقوم البحث على فرضية رئيسة مفادها أن التحديات التي تو اجه تطبيق الأساليب فرضية البحث

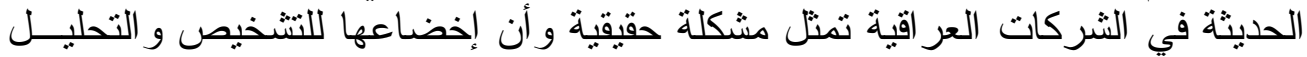

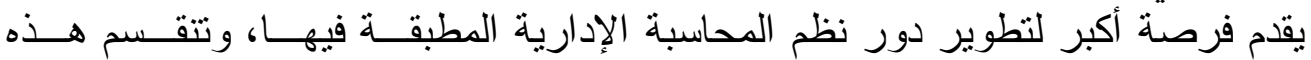
الفرضية إلى عدة فرضيات هي: ألفئ

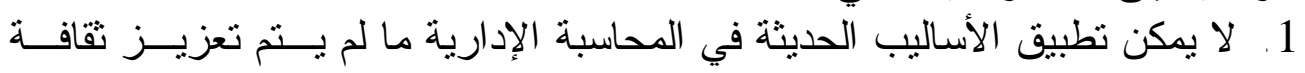
التغيير في الثركات العر اقية.

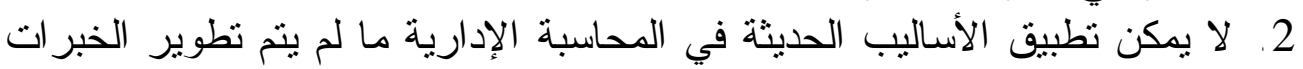

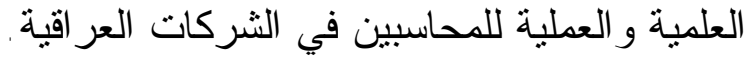




\section{الزيدي [312]}

3. لا يمثل تطبيق الأساليب الحديثة في المحاسبة الإدارية أولوية لكثير من الثركات

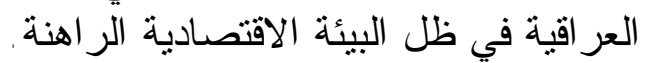

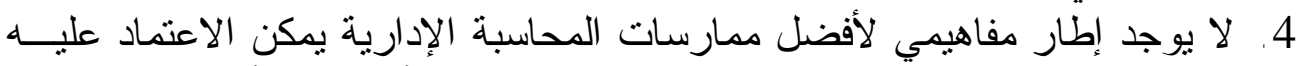
في اختيار ما يتلاءم مع حاجة الثركات العر اقية من الأدو ات و الأساليب الحديثة الأبن.

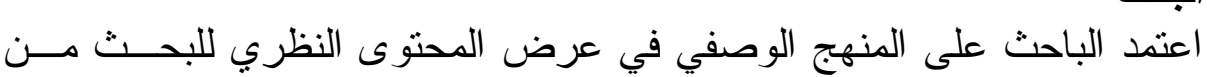

\section{منهج البحث}

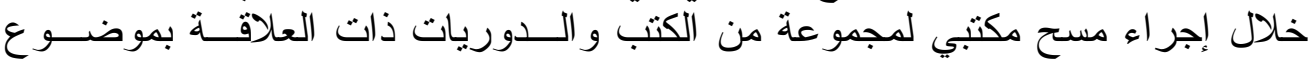

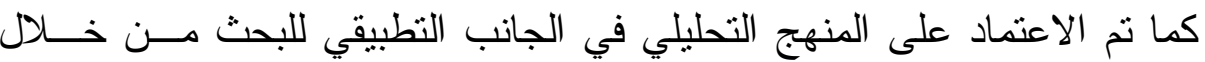

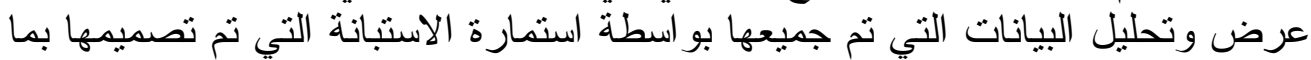

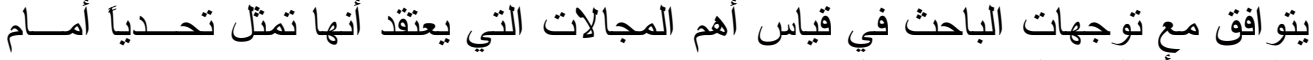

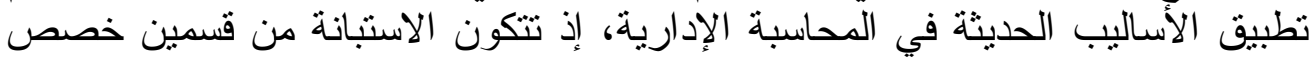

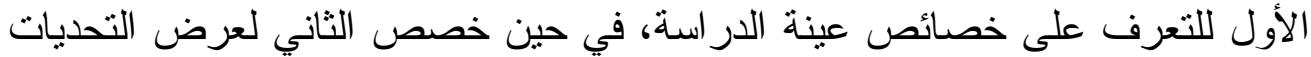

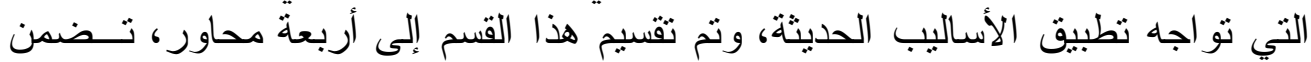

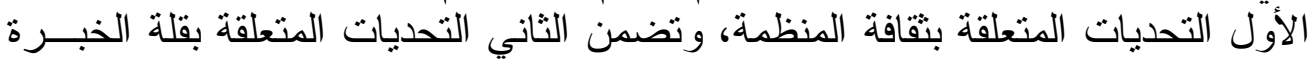

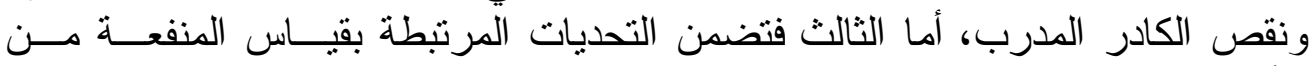
الأساليب الحديثة، في حين تضمن الرابع التحديات المتعلقة بملاءمة بحوث المحاســــة

شملت عينة البحث در اسة لآر اء عينة من المحاسبين في مدينة الموصل بكافــة

\section{عينة البحث}

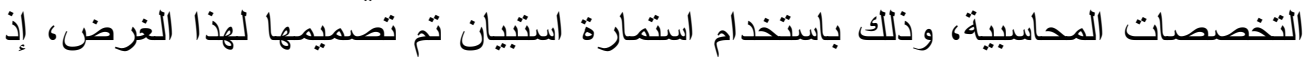

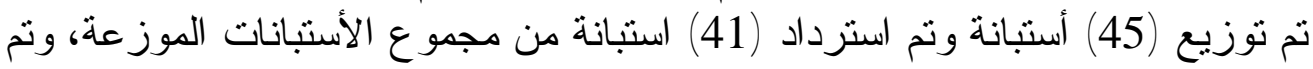

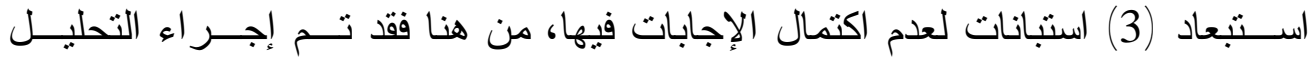

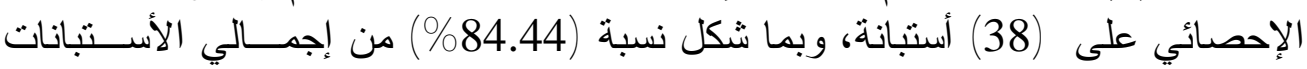
الموزعة.

\section{حدود البحث}

1. إن البحث الحالي مقيد بهدف محدد هو بيان التحديات التي تواجه تطبيق الأساليب

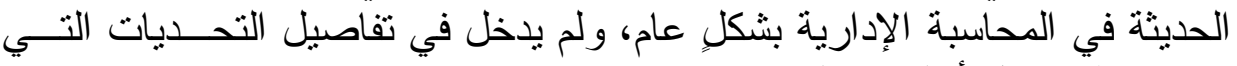
تو اجه تطبيق كل أسلوب على حدة. 
2. لم يتطرق البحث الحالي إلى بيئة و عمليات و أهداف الثركة (الإطـــار المـــوقفي)

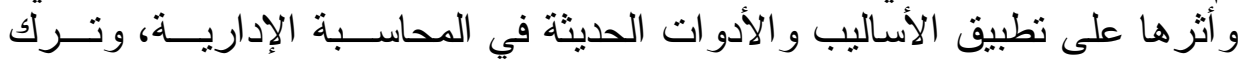

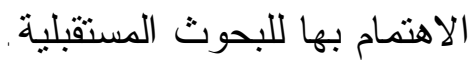

هيكلية البحث: تم تقسيم البحث على المحاور الرئيسة الآتية: - الحاجة إلى تطور المحاسبة الإدارية. - مر احل تطور المحاسبة الإدارية.

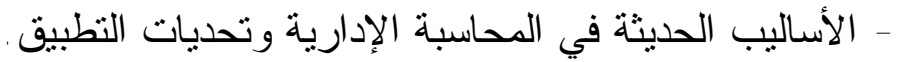
- عرض نتائج الاستبانة وتحليلها.

\section{الحاجة إلى تطور المحاسبة الإدارية}

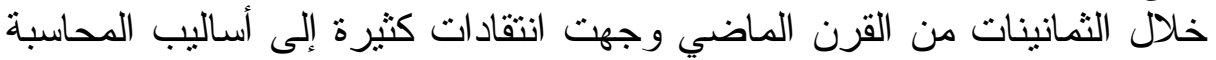

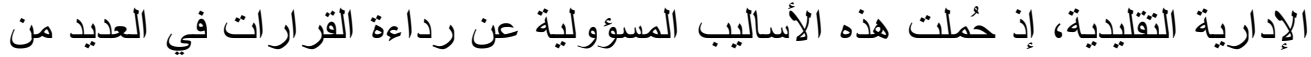

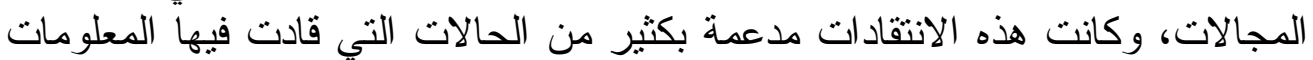

المحاسبية مدر اء الثركات لاتخاذ قر ار ات خاطئة (Dimnik \& Kuder,1989,12).

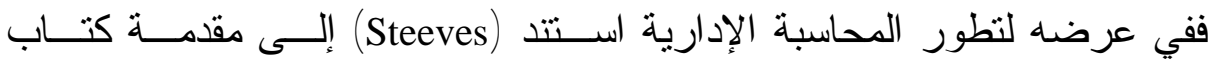

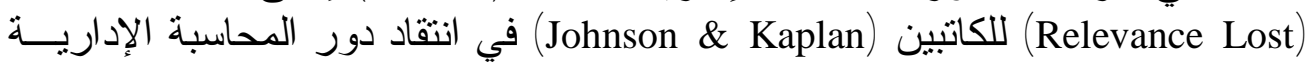

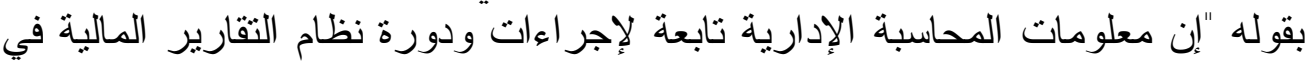

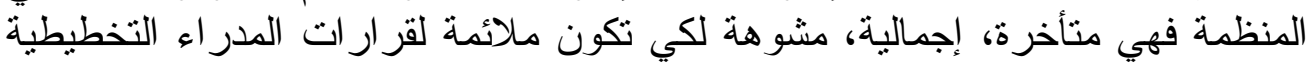

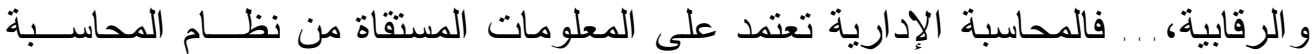

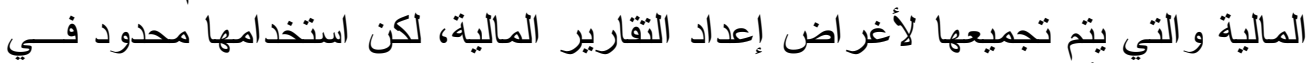
مجال قياس الأداء و الرقابة المنظمية" (Steeves, 1990, 17) .

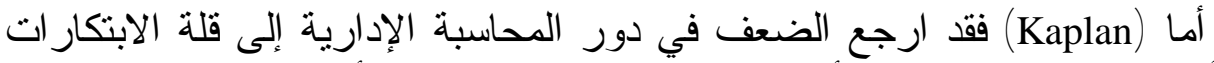

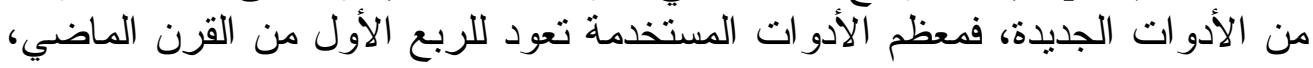

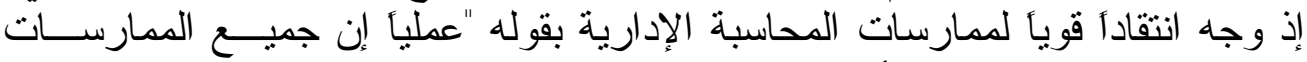

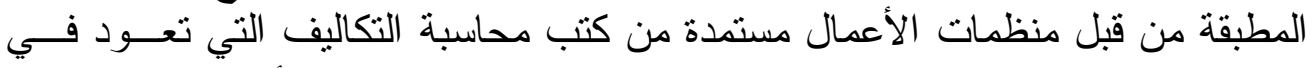

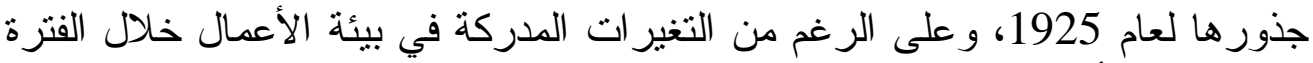

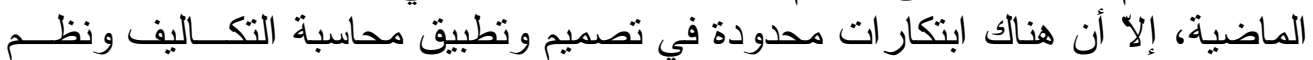

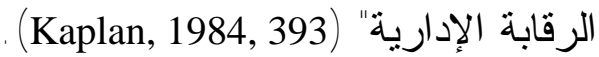

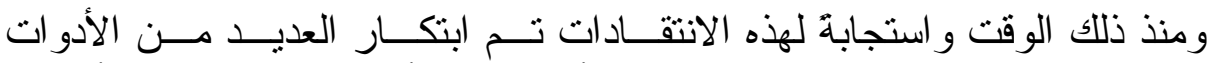

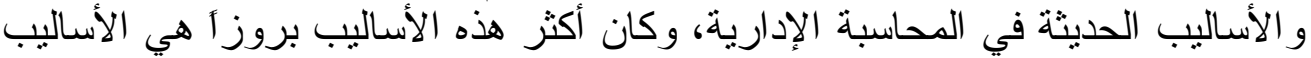

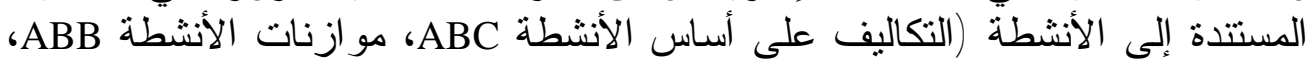




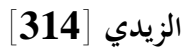

الإدارة على أساس الأنشطة ABM)، و المقارنة المرجعية (Benchmarking)، وبطاقــة

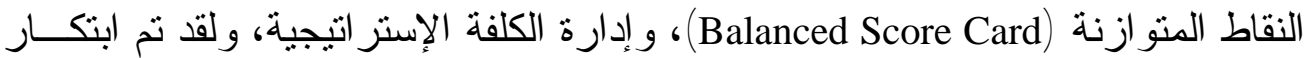

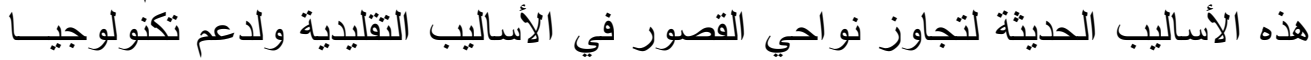

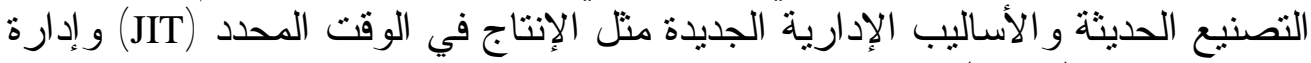

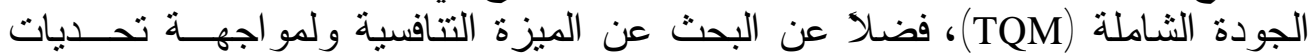

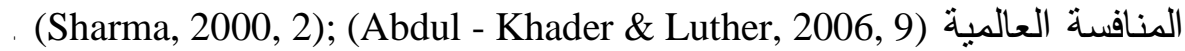

مر احل تطور المحاسبة الإدارية

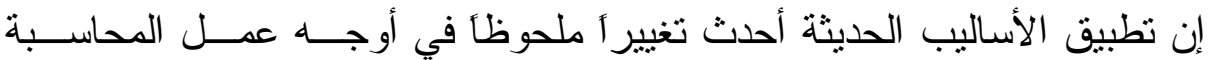

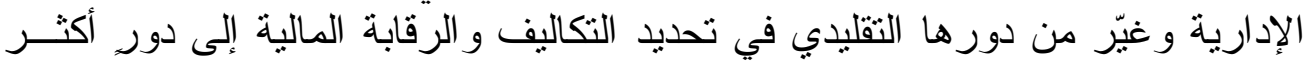

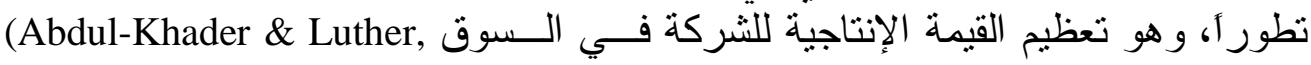
.2006, 9)

وللوقوف على الأسباب التي أدت إلىى هذا التغيير قدمت لجنـــة الإدارة الماليــة

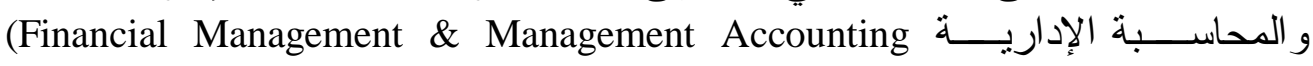
التابعة للاتحاد الدولي للمحاسبين Committee (FMAC))

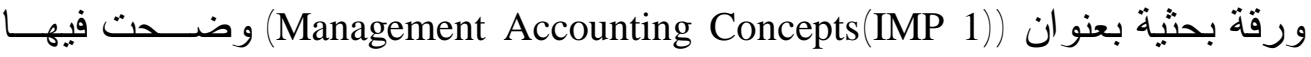

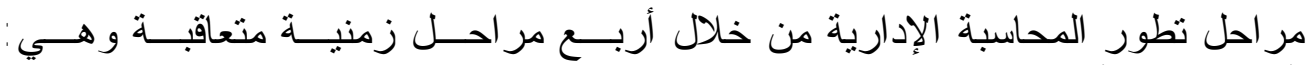
(IFAC, 1998)

\section{المرحلة الأولى: (ما قبل سنة 1950) تحديد التكاليف والرقابة المالية}

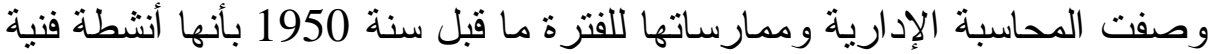

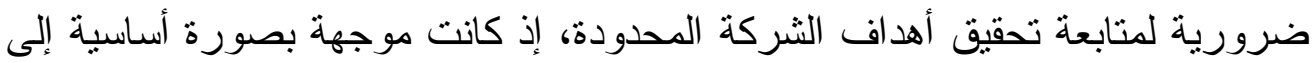

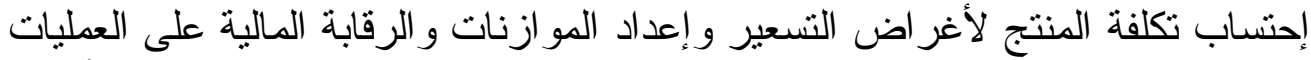

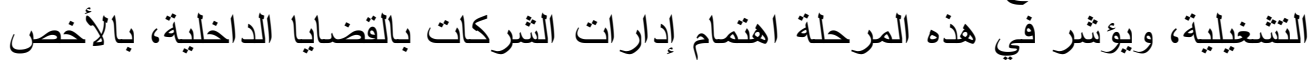

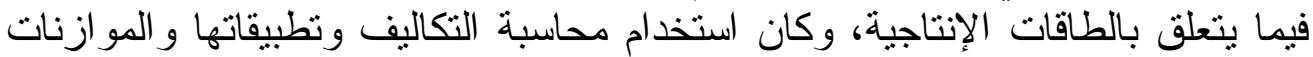

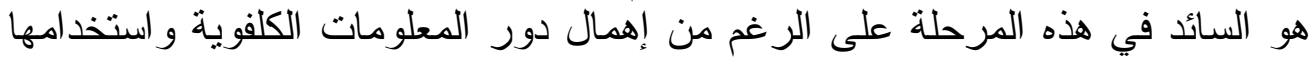

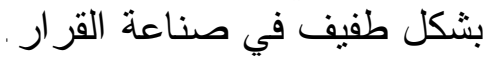

المرحلة الثانية: (من سنة1950 - لغاية سنة 1965) تــوفير المعلومــات لأغـراض التخطيط و الرقابة التمابة

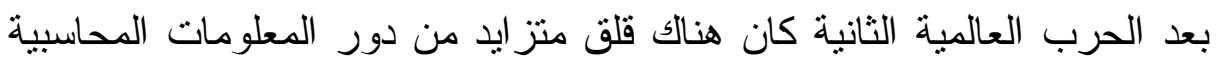
بشكل عام و المعلومات التكاليفية بشكل خاص، ومدى ملاصن ملاعمتها لاحتياجات المستخدمين،

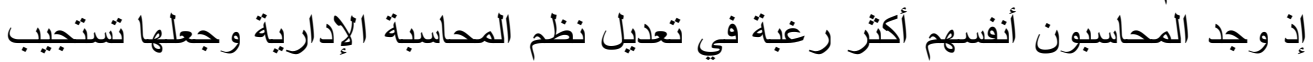


لاحتياجات الإدارة، ففي تلك الفترة تغير اهتمام المحاسبة الإدارية و أزداد تركيزها على الإدي

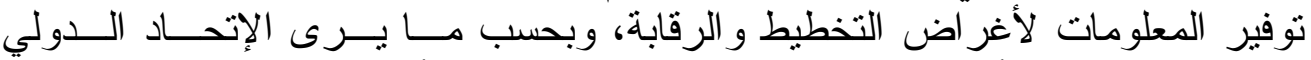

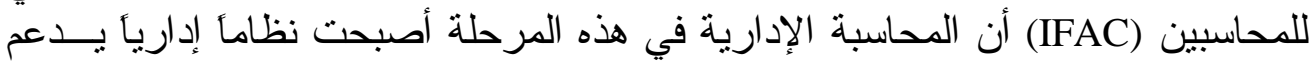

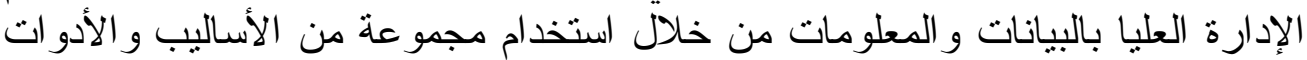

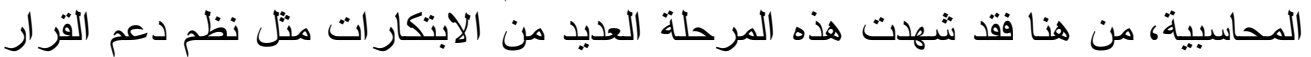

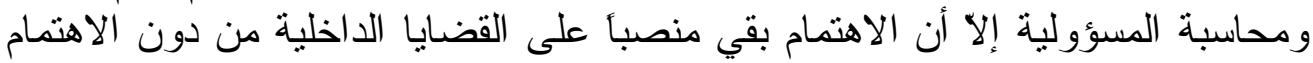

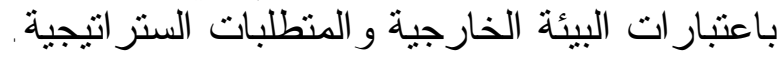

\section{المرحلة الثالثة: (من سنة 1965 - لغاية سنة 1985) تخفيض الضياع والهدر فـي الموارد}

خلال السبعينات من القرن الماضي واجهت منظمات الأعمال تحديات كبيــرة،

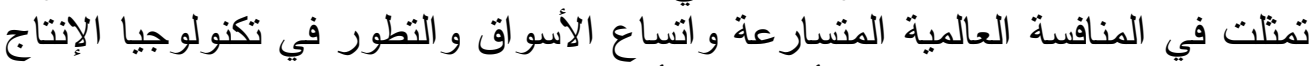

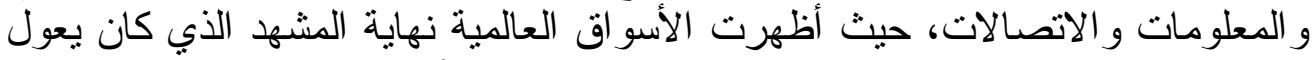

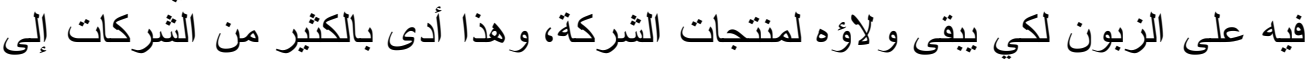

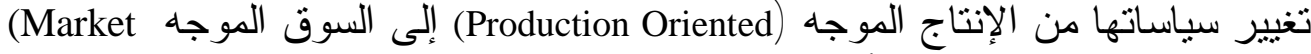

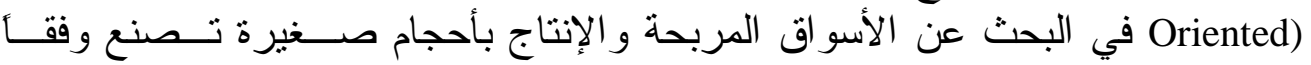
لاحتياجات الزبون (Ning, 2005, 25).

لقد أدى هذا التغير إلى توسيع قاعدة المتطلبات التقنية و الفنية و التي أدت بدور ها

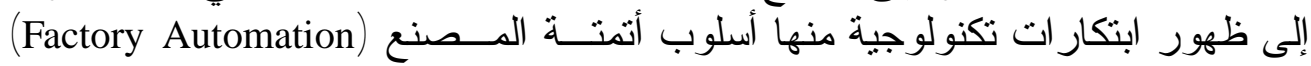

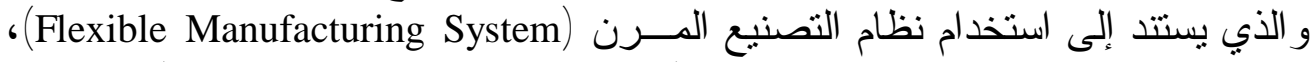

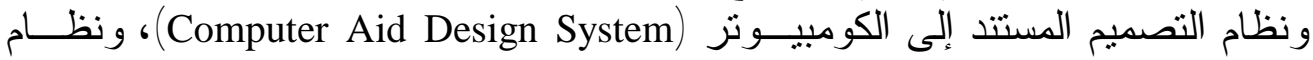

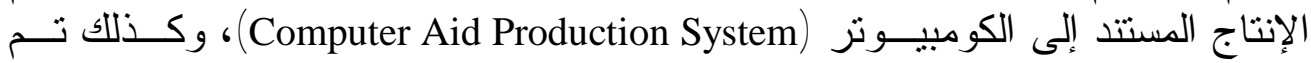
استحداث أساليب إنتاج جديدة ترنكز على درجة التقيد التقني مثل أسلوب الإنتاج فـي

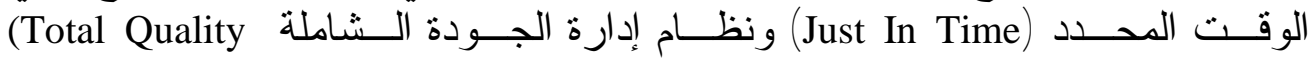
(Ning, 2005, و التي تركز على تخفيض الضياع و الهدر في المــو اردة Management) (Atkinson, 1989, 35) 25)

لقد فرضت هذه التحديات نفسها على منظمات الأعمال و على نظــــ المحاســبة

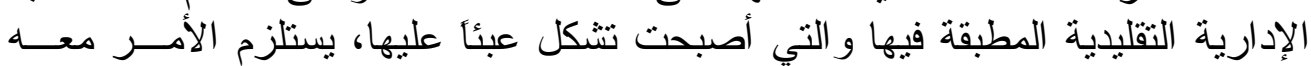

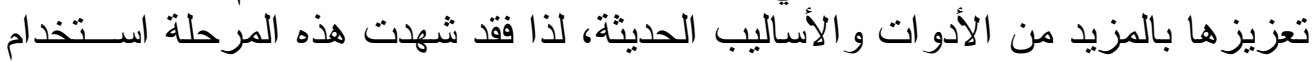

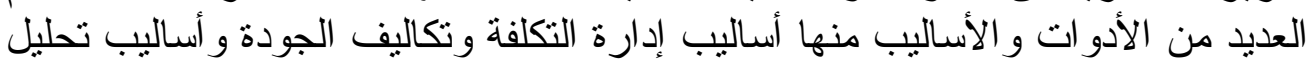




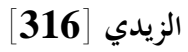

\section{المرحلة الرابعة: (من سنة 1985 - لحد الآن) تعظيم القيمة من خــلل الاســـذام

\author{
الأمثل للموارد
}

منذ بداية النصف الثاني من الثمانينات من القرن الماضي وحتى اليوم لم تــزل الإل

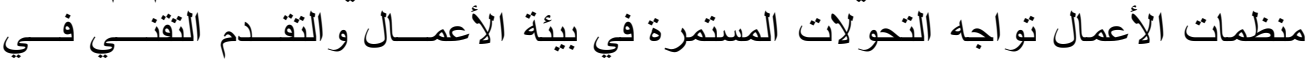

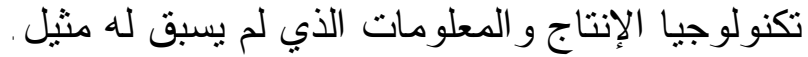

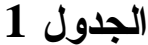

مر احل تطور أدوات وأساليب المحاسبة الإدارية

\begin{tabular}{|c|c|c|c|c|}
\hline 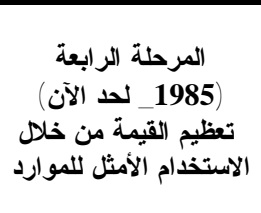 & 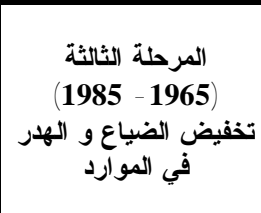 & 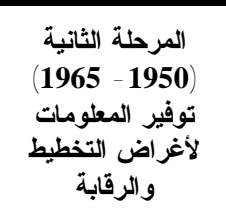 & 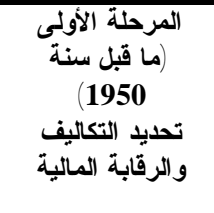 & 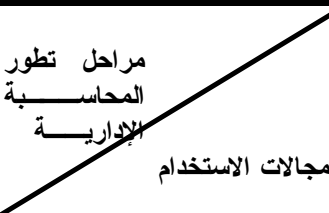 \\
\hline 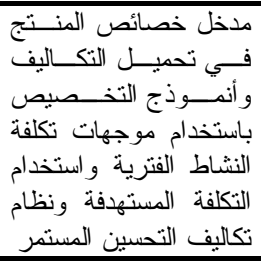 & 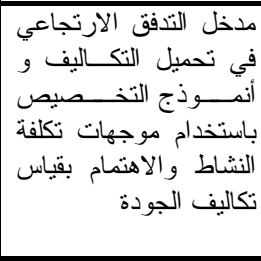 & 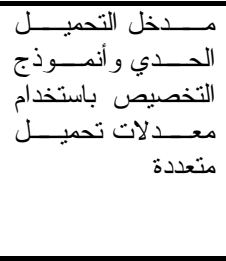 & 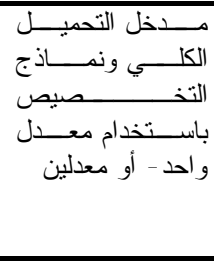 & مجال قياس التكاليف \\
\hline 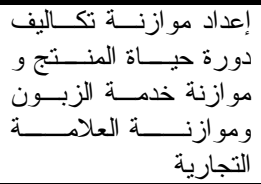 & وإعداد موازنات الجودة الأنشطة & 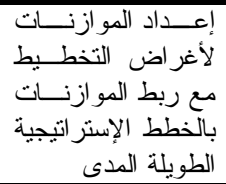 & 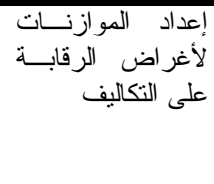 & 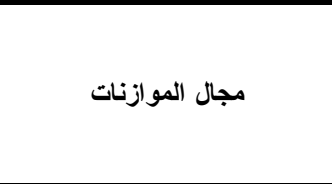 \\
\hline 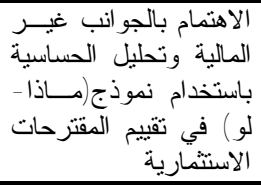 & 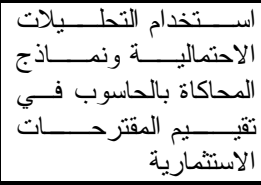 & 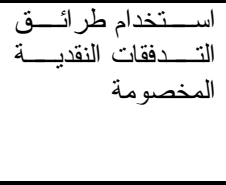 & 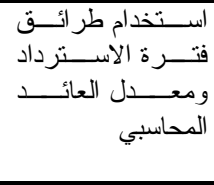 & مجال الموازنات الرأسمالية \\
\hline 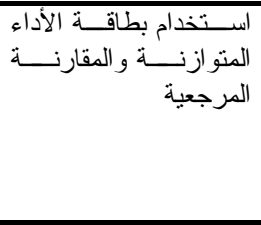 & 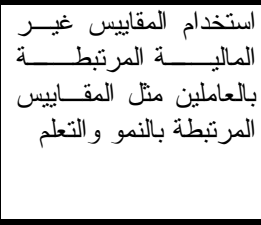 & 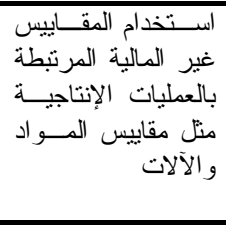 & 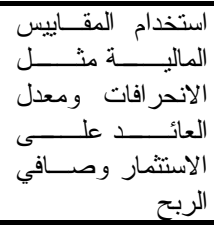 & مجال الرقابة التشغيلية وتقييم \\
\hline 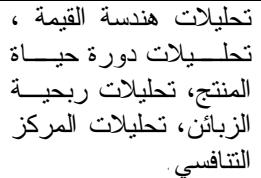 & 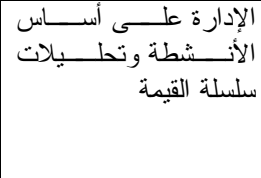 & 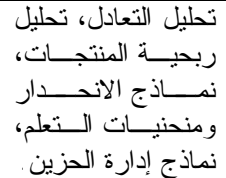 & 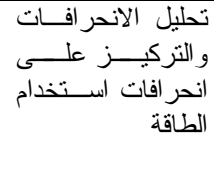 & مجال دعم القرار \\
\hline
\end{tabular}


فعلى سبيل المثال إن الاستخدام الواسع لشبكة الانترنت أدى إلى ظهور التجارة

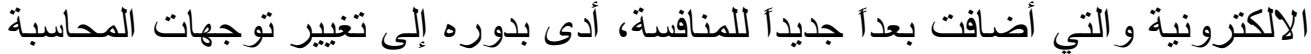

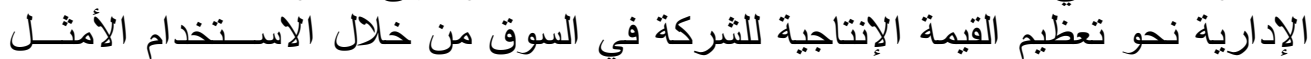

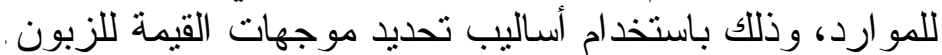

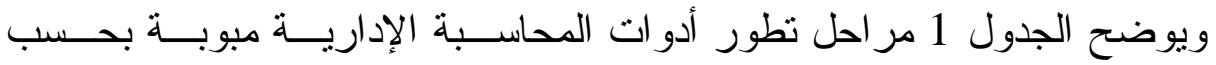
مجالات استخدام المحاسبة الإدارية في المنظمة.

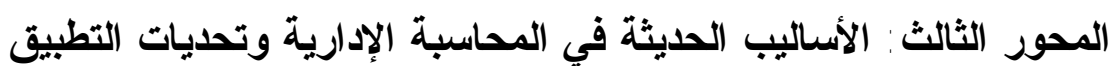

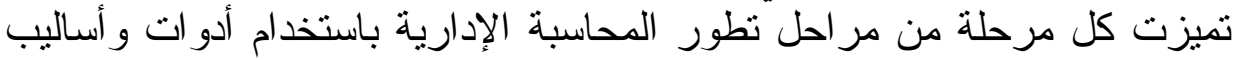

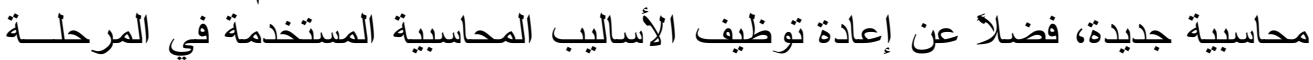

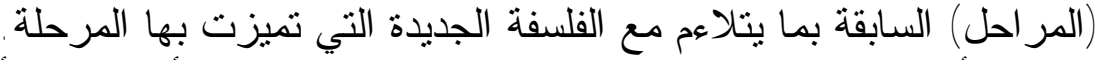

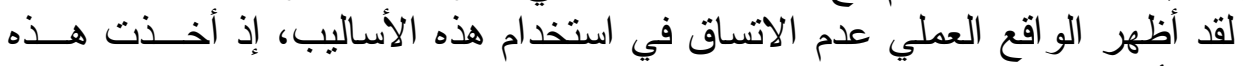

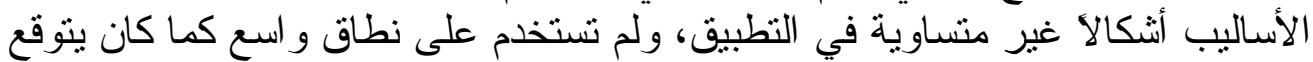

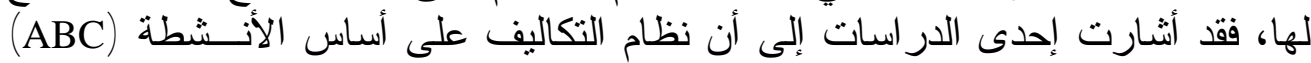

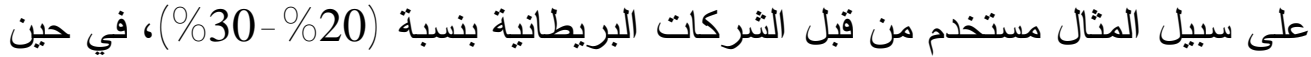

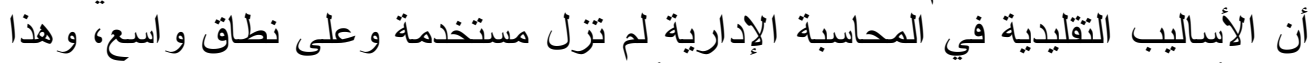

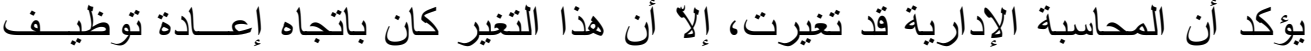

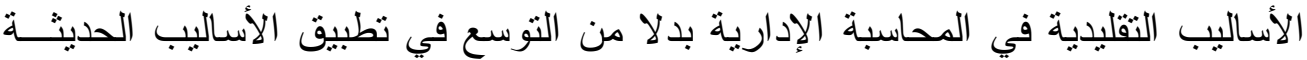
(بتصرف (Burns,2000,2) (Steeves,1990,18) و هذا يقودنا إلى التساؤل لماذا تتغير المحاسبة الإدارية ببطئ شديد ور اء التغير ات

المتسار عة في بيئة الأعمال الحديثة؟ الفئ

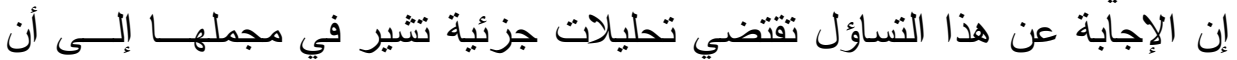

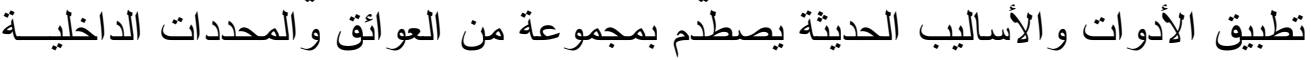

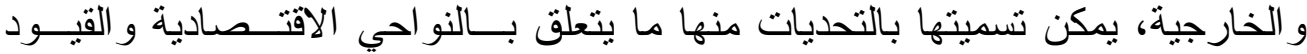

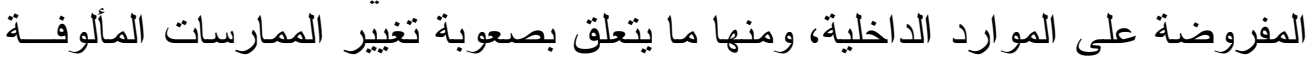
التي قد تحول دون تطبيق هذه الأدوات و الأساليب و التي يمكن عرضها باتئ بالثكل الآتي:

أ. المنظمة وثقافة التغيير

إن تطبيق الأساليب و الأدو ات الحديثة بتطلب خلق التق البيئة التي يقتنع فيها الأفر اد في

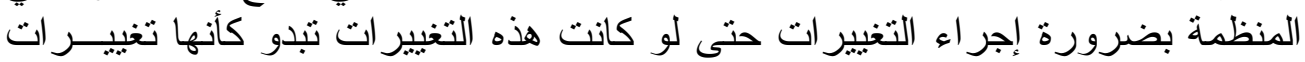

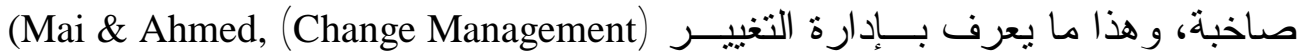




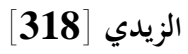

و هنا يمكن تحديد ثلاثة مستويات من التحديات المرتبطة بثقافة المنظمة التي تو اجه تطبيق الأساليب الحديثة و هي (www.esnips.com/search/costaccounting) :

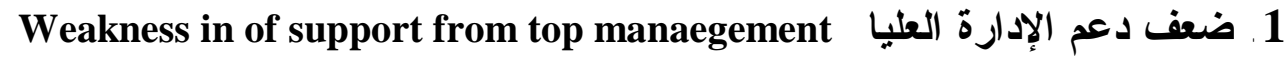

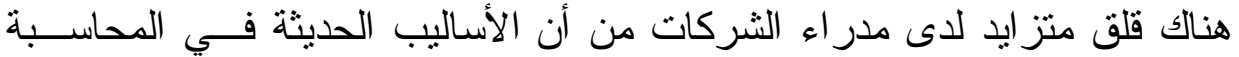

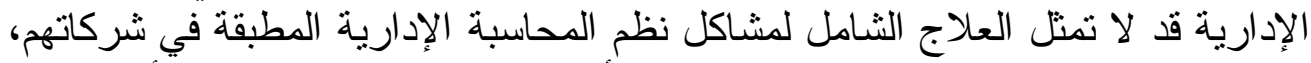

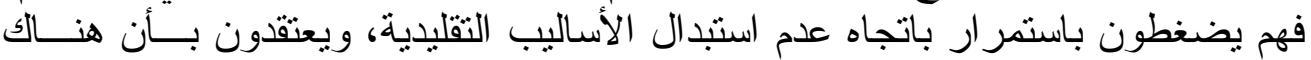

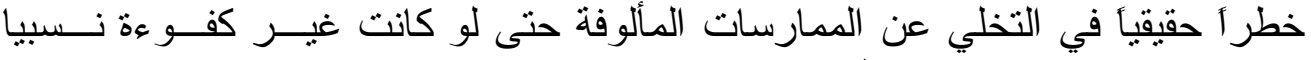
. (Dimnik \& Kuder,1989,14)"

ومن جانب آخر فإن المختصين في المحاسبة الإدارية يتحركون باتجاه مــشاركة

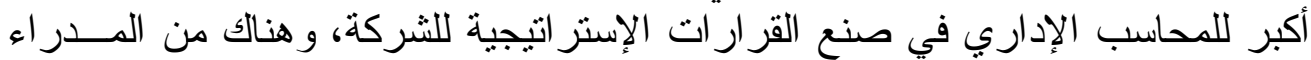

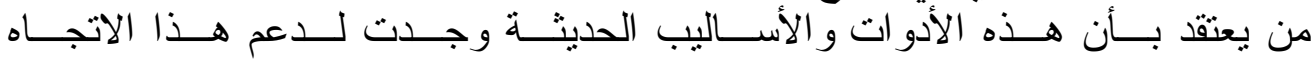
(Steeves,1990,18)

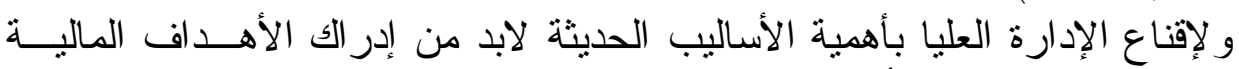

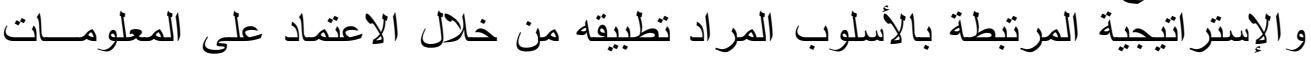

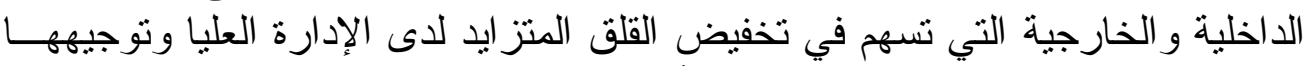

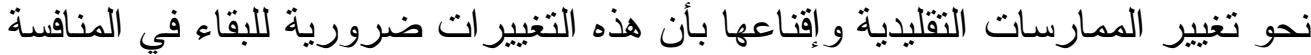
. (Mai \& Ahmed,2005,46)

2. معارضة الكادر المحاسبي للتغيير \&esistance from Staff to change

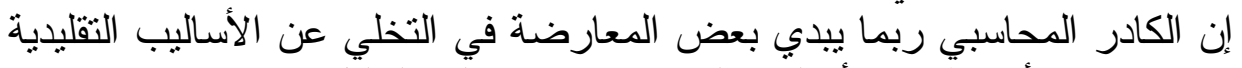

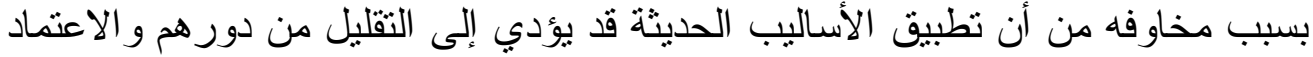

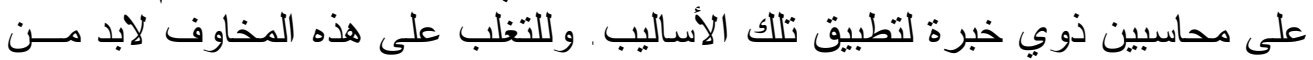

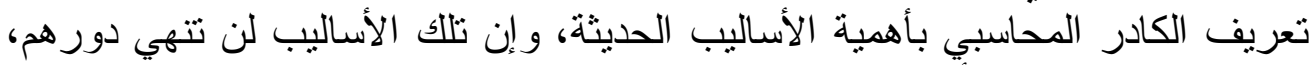

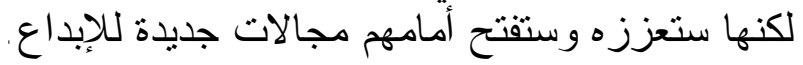

3.عدم تعاون المستويات الأخرى Non-cooperation at other levels

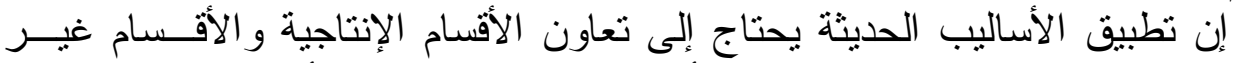

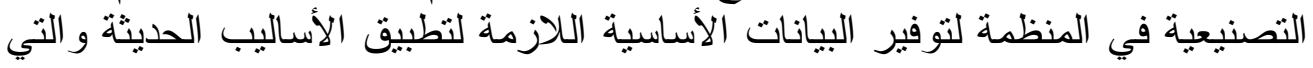

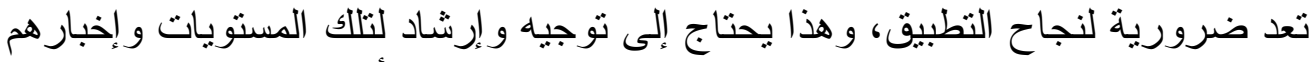

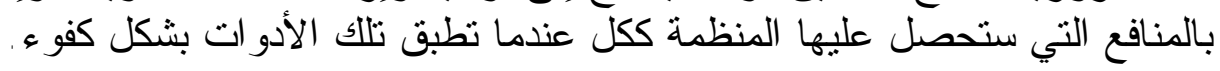

ب. قلة الخبرة لاى المحاسبين الإداريين ونقص الكادر المدرب

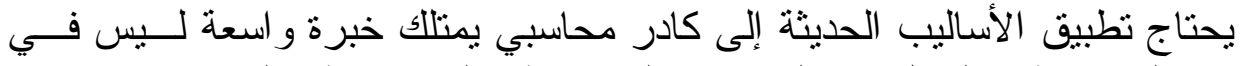
الجوانب المحاسبية فقط، بل في المجالات التصنيعية و التـسويقية و المجــالات غيــر 


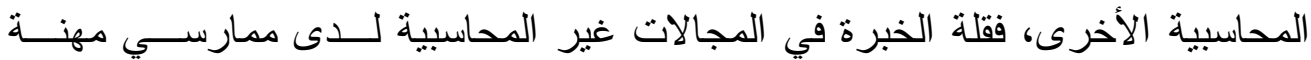

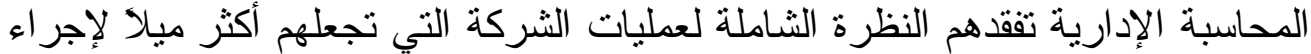
التغيير ات في نظم المحاسبة الإدارية وتعزيز ها بالمزيد من الأساليب و الأدوات التهات الحديثة . (Mai \& Ahmed, 2005, 48) (Sheildes, et.al,1991, 72)

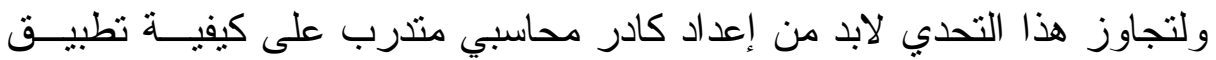

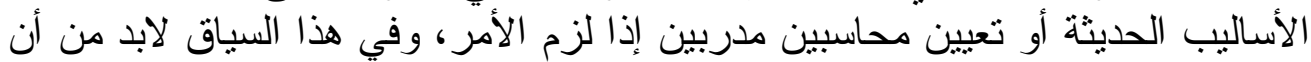

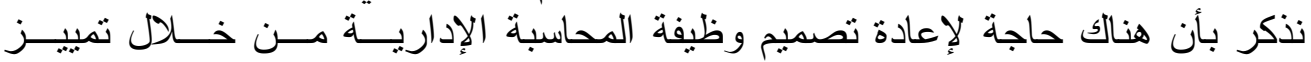

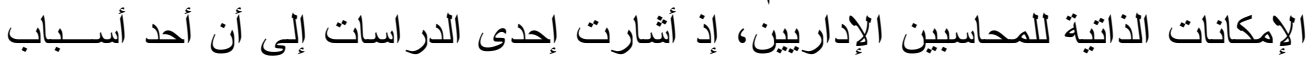

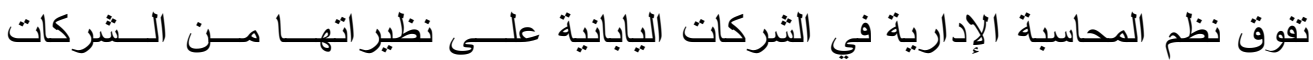

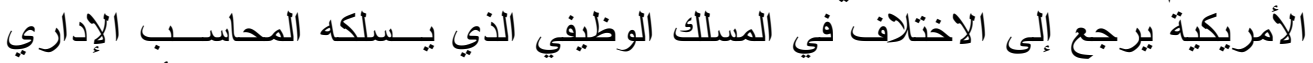
ومحاسب التكاليف في كلا البلدين، فمعظم محاسبي التكاليف في الثركات فئ الأمريكية ينت

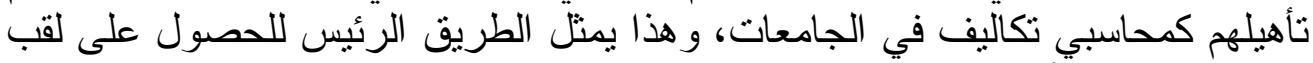

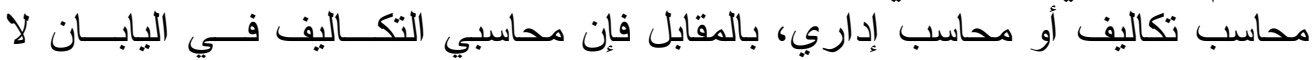

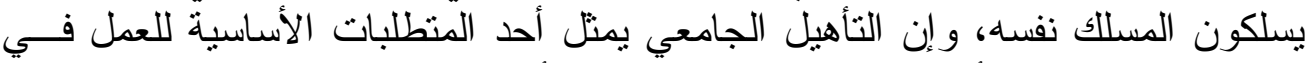

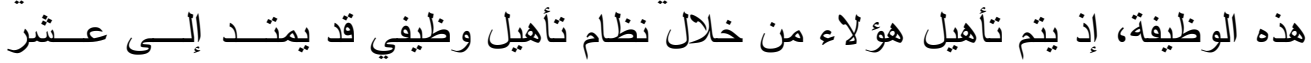

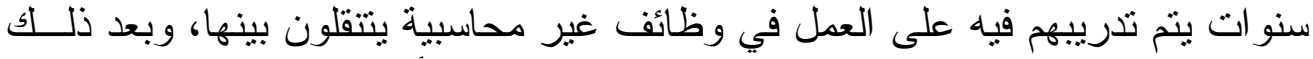

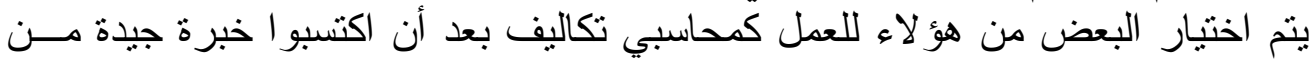
الأقسام التي عملو ا بها (Shields, et.al, 1991, 72).

ت. قياس المنفعة للأدوات الحديثة

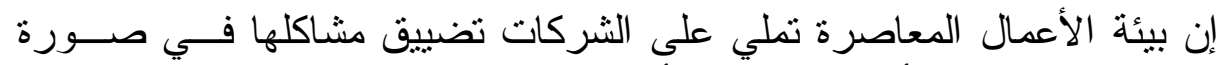

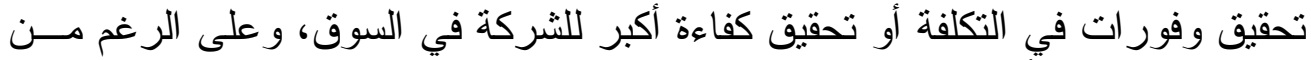

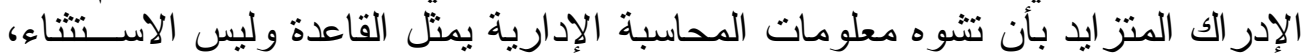

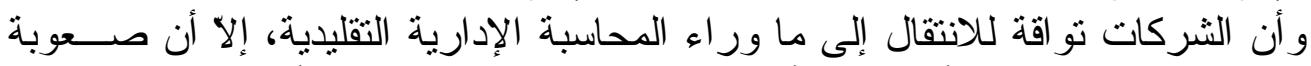

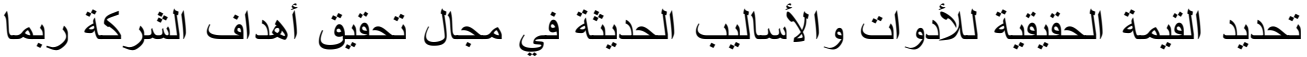

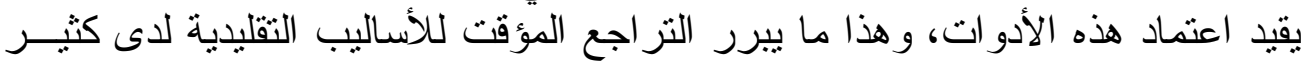
من الثركات (Garg, et.al, 2003, 32) .

ث. بحوث المحاسبة الإدارية

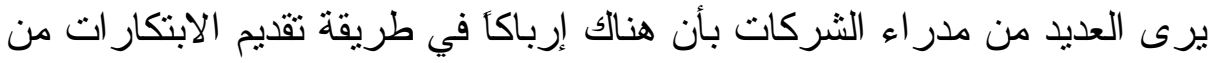

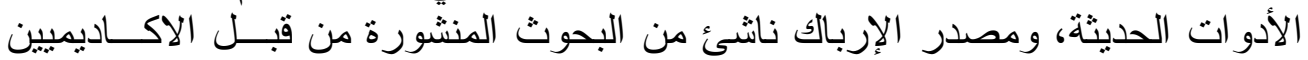
و المنظمات المختصة في المحاسبة الإدارية، إذ يحاول كل منهم تقديم الأسلوب المبنكر 


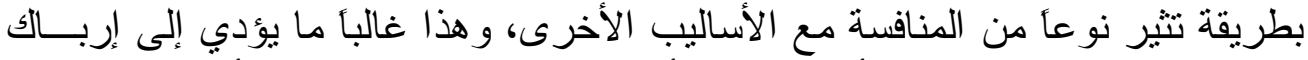

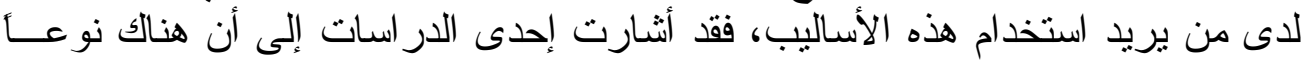

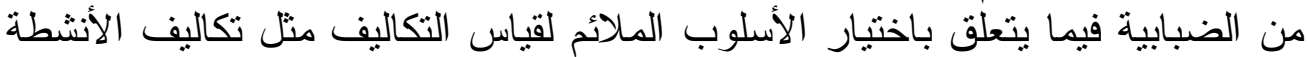

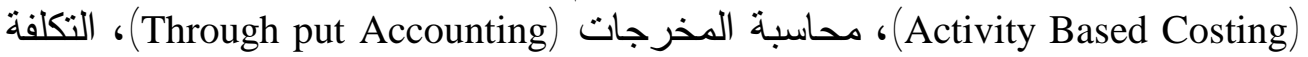

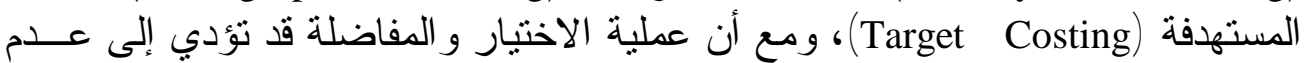

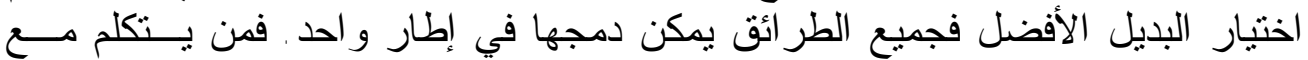

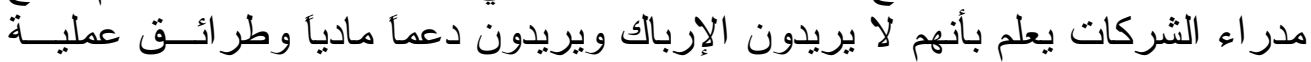
تساعدهم في صنع أفضل القرار ات (Cokins,2001,43).

\section{المحور الرابع: عرض نتائج الاستبانة وتحليلها}

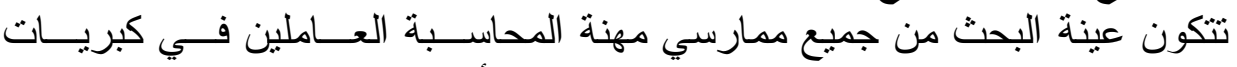
الثركات الصناعية في مدينة الموصل، إذ نم نوزيع الأستبانات بطريقة العينة العينة العشو ائية

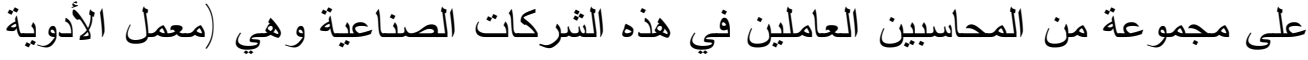

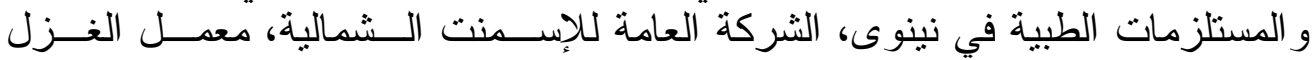

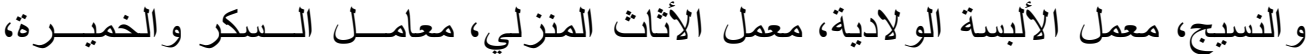

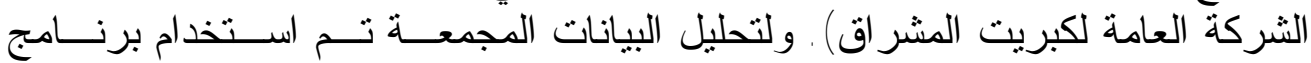
(Excel)

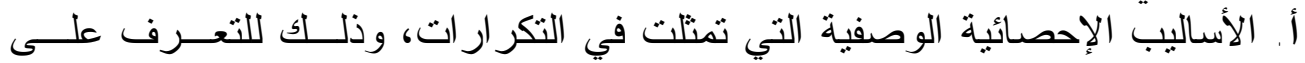
خصائص عينة البحث و التكرار الت النسية النسبية لبيان مقدار النسبة المئوية لكل فئة من

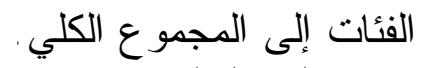

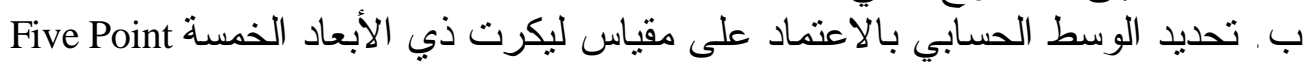

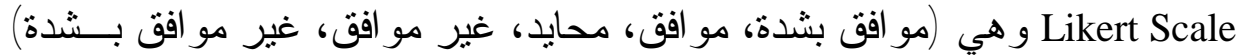

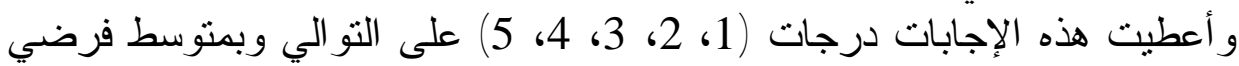

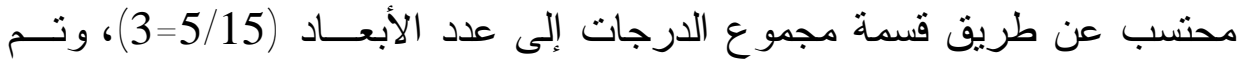

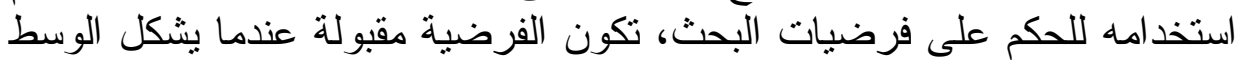

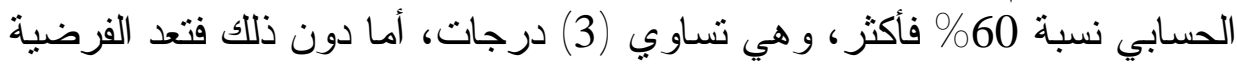
ت. الانحر اف المعياري وتم استخدامه من أجل التعرف على مقــدار التـشتـت فـي الإجابات حول الوسط الحسابي. 
أولاً - تحليل خصائص عينة البحث

\begin{tabular}{|c|c|c|c|c|c|}
\hline \multicolumn{6}{|c|}{ 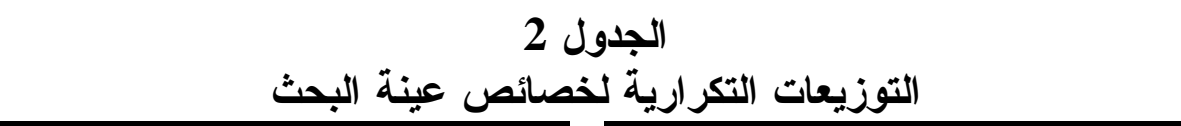 } \\
\hline$\%$ & التكرار & الاختصاص الدقيق & $\%$ & الت التكر ار & التحصيل العلمي \\
\hline 57.9 & 22 & محاسب مالي & 10.5 & 4 & إعدادية \\
\hline 0 & 0 & محاسب إداري & 26.3 & 10 & دبلوم \\
\hline 23.7 & 9 & محاسب تكاليف & 63.2 & 24 & بكالوريوس \\
\hline 18.4 & 7 & مدقق حسابات & 0 & 0 & شهادة عليا \\
\hline$\% 100$ & 38 & المجموع & $\% 100$ & 38 & المجموع \\
\hline$\%$ & التكر ار & عدد سنوات الخبرة & $\%$ & التكر ار & الارجة الوظيفية \\
\hline 23.7 & 9 & 1 - 5 سنة & 21.1 & 8 & معاون محاسب \\
\hline 23.7 & 9 & 10- 5 & 26.3 & 10 & محاسب \\
\hline 18.4 & 7 & $15-10$ & 15.8 & 6 & محاسب أقدم \\
\hline 13.1 & 5 & 20- 15 & 36.8 & 14 & مدير حسابات \\
\hline 21.1 & 8 & 20 - سنة فأكثر & $\% 100$ & 38 & المجموع \\
\hline$\% 100$ & 38 & المجموع & & & \\
\hline
\end{tabular}

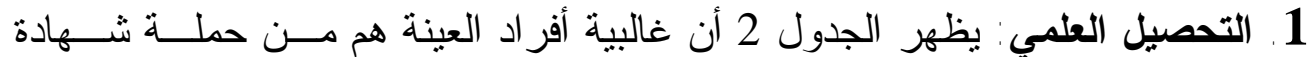

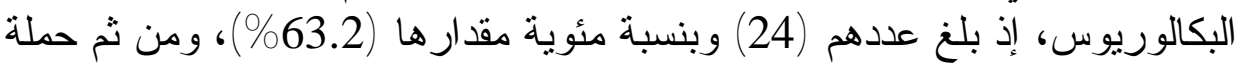

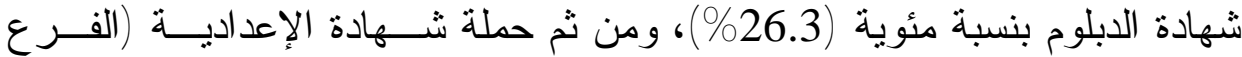

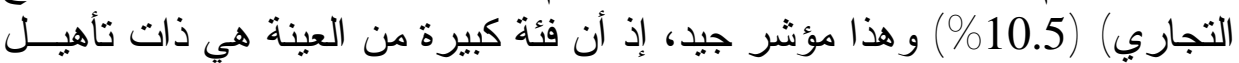

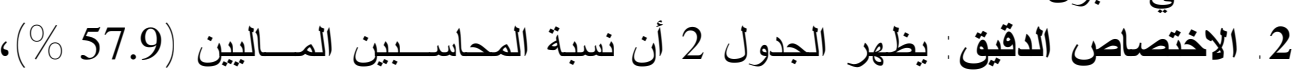

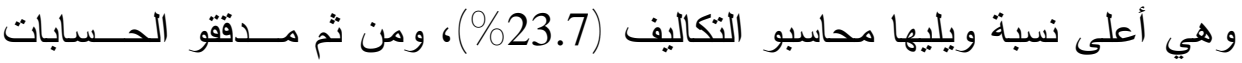

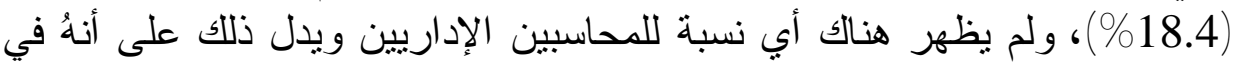

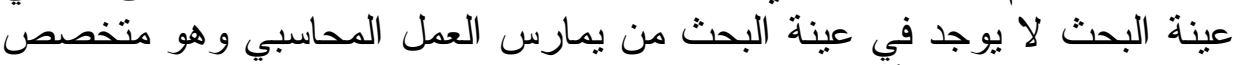

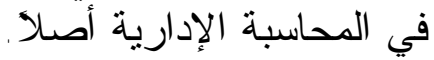




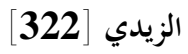

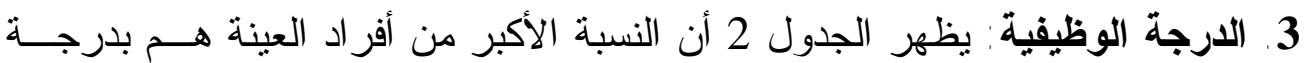

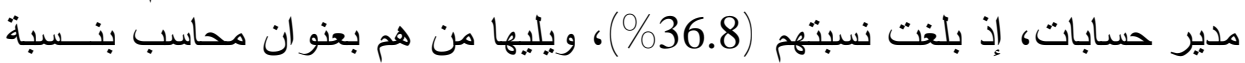

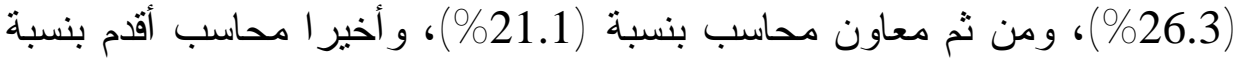
. (\% 15.8)

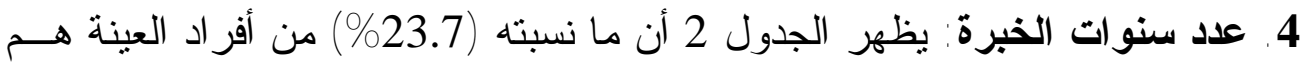

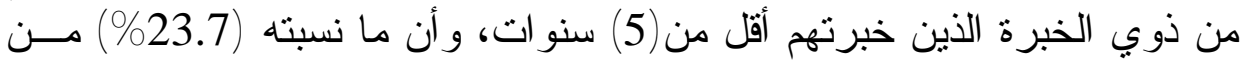

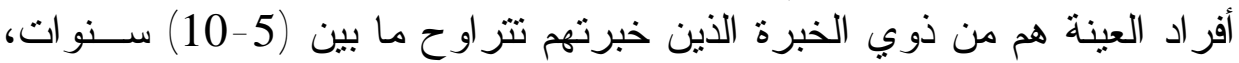

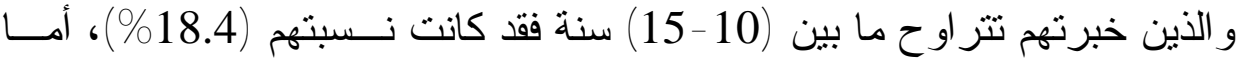

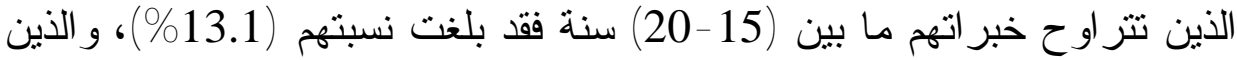

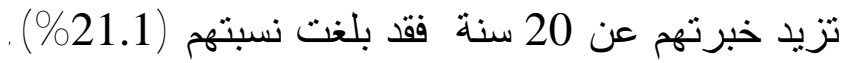

ثثانياً - التحديات المرتبطة بتطبيق الأساليب الحديثة في المحاسبة الإدارية

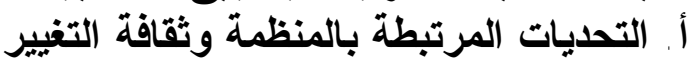

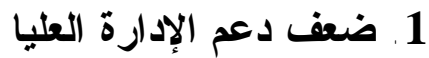

تم قياس هذا المتغير من خلال الأسئلة المبينة في الجدول 3 وذللك بإيجاد كل من الوسط الحسابي و الانحر اف المعياري لإجابات أفر اد عينة البحث وكالآتي:

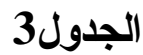

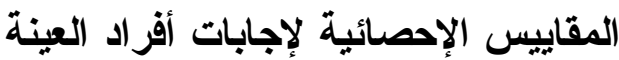

حول التحديات المتعلقة بلدع الإدارة العليا لتطبيق الأساليب الحديثة الإبية

\begin{tabular}{|c|c|c|c|c|c|c|c|c|c|c|c|c|}
\hline \multirow{2}{*}{ 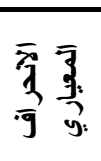 } & \multirow{2}{*}{ الحسابي } & \multicolumn{2}{|c|}{ غير موافق } & \multicolumn{2}{|c|}{ غير موافق } & \multicolumn{2}{|c|}{ محايد } & \multicolumn{2}{|c|}{ مو افق } & \multicolumn{2}{|c|}{ موافق بثدة } & /لإجابة \\
\hline & & $\%$ & عدد & $\%$ & عدد & $\%$ & عدد & $\%$ & عدد & $\%$ & عدد & 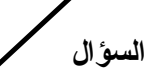 \\
\hline 0.963 & 3.421 & 0 & 0 & 23.7 & 9 & 21 & 8 & 44.8 & 17 & 10.5 & 4 & 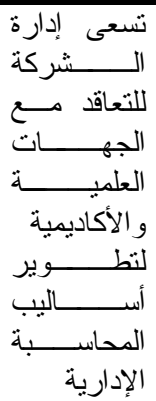 \\
\hline 0.993 & 3.526 & 0 & 0 & 26.7 & 9 & 13.15 & 5 & 50 & 19 & 13.15 & 5 & الــــــــر إدركة \\
\hline
\end{tabular}




\begin{tabular}{|c|c|c|c|c|c|c|c|c|c|c|c|c|}
\hline \multirow{2}{*}{$\begin{array}{l}\bar{y} \\
\bar{y} \\
\bar{y}\end{array}$} & \multirow{2}{*}{ الحسابي } & \multicolumn{2}{|c|}{ غير مو افقى } & \multicolumn{2}{|c|}{ غير موافق } & \multicolumn{2}{|c|}{ محايد } & \multicolumn{2}{|c|}{ مو افق } & \multicolumn{2}{|c|}{ موافق بثدة } & / الإجابة / مقياس \\
\hline & & $\%$ & عدد & $\%$ & عدد & $\%$ & عدد & $\%$ & عدد & $\%$ & عدد & السؤال \\
\hline & & & & & & & & & & & & 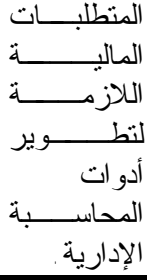 \\
\hline 1.024 & 3.052 & 7.9 & 3 & 21.1 & 8 & 34.2 & 13 & 31.6 & 12 & 5.2 & 2 & 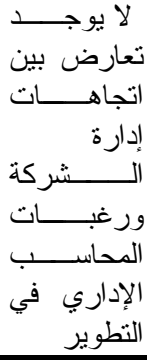 \\
\hline 0.992 & 3.552 & 0 & 0 & 18.4 & 7 & 26.4 & 10 & 36.8 & 14 & 18.4 & 7 & 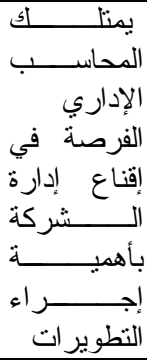 \\
\hline 0.781 & 3.368 & 2.6 & 1 & 13.1 & 5 & 31.7 & 12 & 47.3 & 18 & 5.3 & 2 & 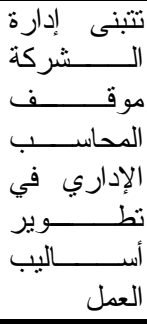 \\
\hline 0.968 & 3.384 & & & & & & & & & & & العنوسط \\
\hline
\end{tabular}

يبين الجدول 3 التحديات المتعلقة بدعم الإدارة العليا لتطبيق الأساليب الحديثــة طبقأ لمنوسطها الحسابي، كما يبين أيضاً نسبة المستجيبين تحت كل درجة من درجات الإن 
الزيدي [324

المو افقة على هذه التحديات، فضلا عن الانحر اف المعياري للإجابات لكل تحدٍ علـى حدة.

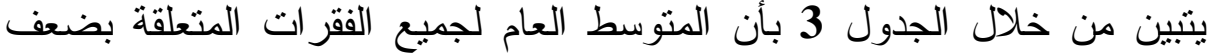

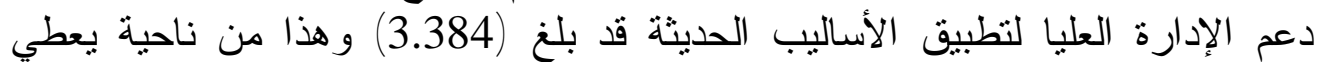

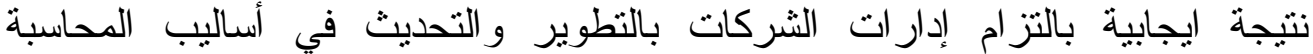

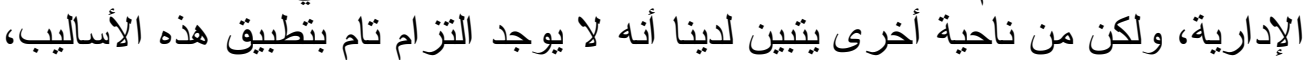

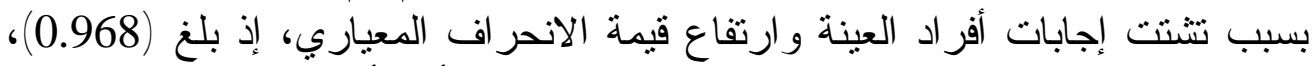

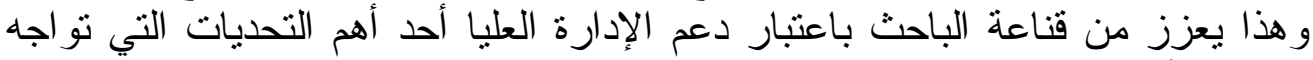
تطبيق الأساليب الحديثة.

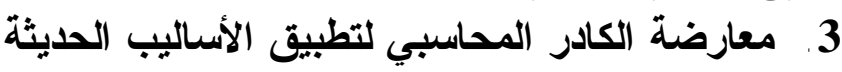

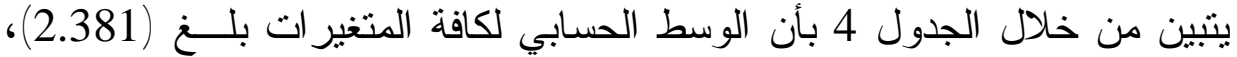

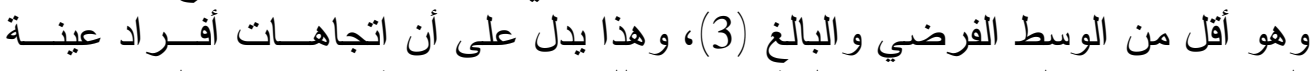

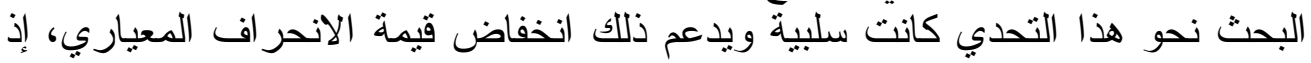

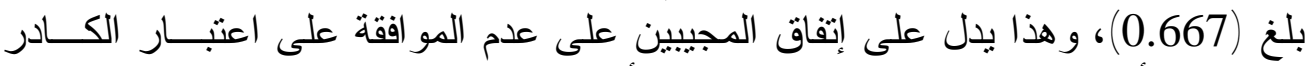

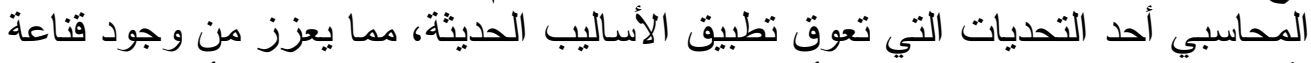
بأن المحاسبين ير غبون بتطوير أدو اتهم بالثكل الذي يحقق لهم مساهمة أكبر في إدارة

\begin{tabular}{|c|c|c|c|c|c|c|c|c|c|c|c|c|}
\hline & & & يوين & فرادر & خة & دول & $\sqrt{2}$ & ـ الإلإ & $\mathbf{2}$ & & & \\
\hline \multirow[t]{2}{*}{ المعياري } & \multirow[t]{2}{*}{ الحسابي } & \multicolumn{2}{|c|}{ مو غيّت } & \multicolumn{2}{|c|}{ غير موافق } & \multicolumn{2}{|c|}{ محايد } & \multicolumn{2}{|c|}{ مو افق } & \multicolumn{2}{|c|}{ مو افقدة } & \\
\hline & & $\%$ & عدد & $\%$ & عدد & $\overline{\%}$ & عدد & $\%$ & عدد & $\%$ & عدد & السؤال \\
\hline 0.708 & 2.394 & 5.3 & 2 & 57.9 & 22 & 28.9 & 11 & 7.9 & 3 & 0 & 0 & الطية معاسبي الحبدي الحالي \\
\hline 0.624 & 2.368 & 5.2 & 2 & 55.2 & 21 & 36.9 & 14 & 2.7 & 1 & 0 & 0 & 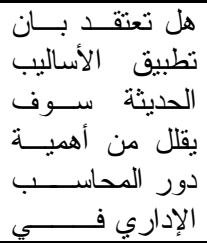 \\
\hline
\end{tabular}




\begin{tabular}{|l|l|l|l|l|l|l|l|l|l|l|l|l|}
\hline & & & & & & & & & & & & \\
\hline 0.667 & 2.381 & & & & & & & & & & & الثركة العنو \\
\hline
\end{tabular}

3. عدم تعاون المستويات الأخرى في تطبيق الأساليب الحديثة

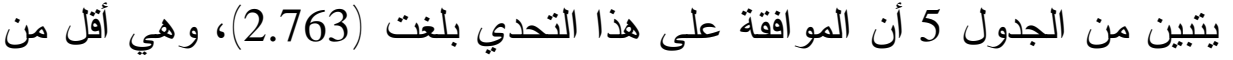

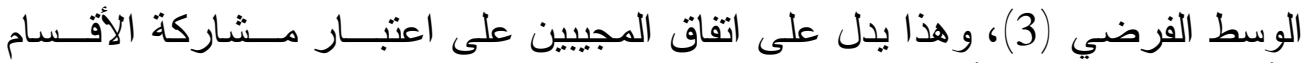

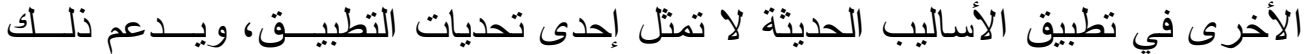

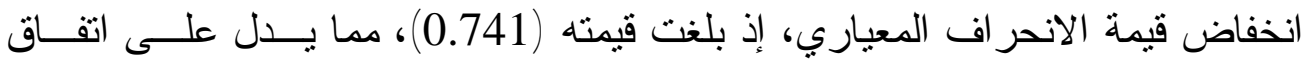

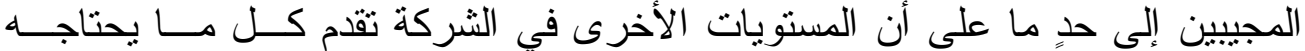
المحاسب الإداري أو محاسب التكاليف من معلومات تسهم في تطوير أساليب العمل.

\section{الجدول 5}

المقاييس الإحصائية لإجابات أفراد المئول العينة حول

التحديات المتعلقة بمشاركة المستويات الأخرى في تطبيق الأساليب الحديثة الإيثة

\begin{tabular}{|c|c|c|c|c|c|c|c|c|c|c|c|c|}
\hline \multirow{2}{*}{ المعياري } & \multirow{2}{*}{ الحسابط } & \multicolumn{2}{|c|}{ غير مو افق } & \multicolumn{2}{|c|}{ غير موافق } & \multicolumn{2}{|c|}{ محايد } & \multicolumn{2}{|c|}{ مو افق } & \multicolumn{2}{|c|}{ بثودة } & مقيا \\
\hline & & $\%$ & عدد & $\%$ & عدد & $\%$ & عدد & $\%$ & عدد & $\%$ & عدد & السؤوآل \\
\hline 0.741 & 2.763 & 2.6 & 1 & 34.3 & 13 & 47.3 & 18 & 15.8 & 6 & 0 & 0 & 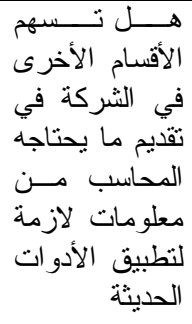 \\
\hline 0.741 & 2.763 & & & & & & & & & & & المتوسط العام \\
\hline
\end{tabular}

إن إجابات أفر اد عينة البحث عن هذا المحور تؤكد أن ثقافة التغيير بمسستوياتها

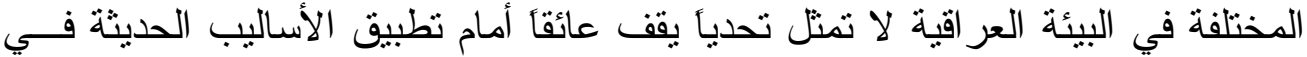

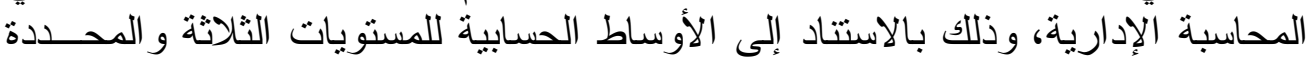

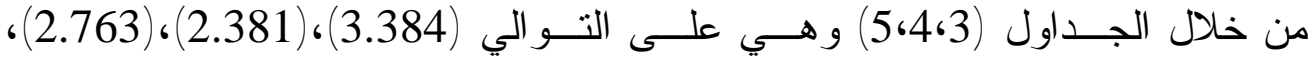

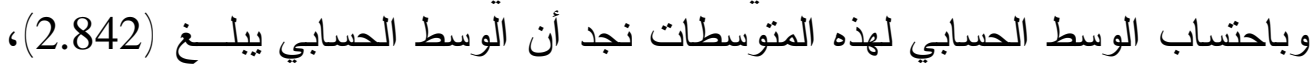

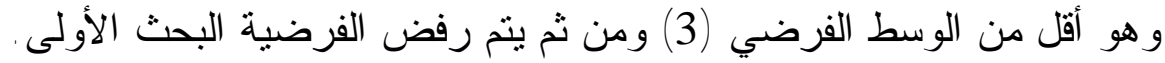


[326] الزيدي [3

ب. التحديات المتعلقة بقلة الخبرة ونقص الكادر المدرب

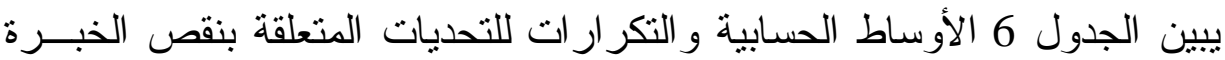

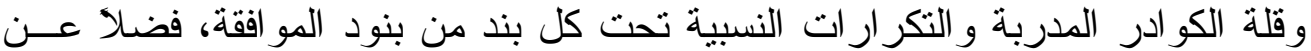
الانحر افات المعيارية لكل تحدٍ على حدة.

\begin{tabular}{|c|c|c|c|c|c|c|c|c|c|c|c|c|}
\hline & & كرب & 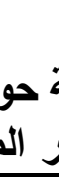 & () & رنق & 10 & ائيً & كقا & يبير اله & تحديا & & \\
\hline الاتحراف & الوسط & إفق & غير بث & & & & & فق & & بثدة & & $\omega$ \\
\hline المعياري & الحسابي & $\%$ & عدد & $\%$ & عدد & $\%$ & عدد & $\%$ & عدد & $\%$ & عدد & \\
\hline 0.613 & 3.789 & 0 & 0 & 5.2 & 2 & 15.9 & 6 & 73.7 & 28 & 5.2 & 2 & 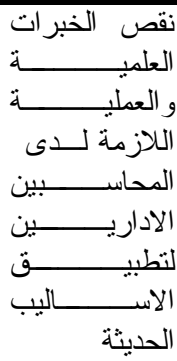 \\
\hline 0.929 & 3.631 & 2.6 & 1 & 13.1 & 5 & 13.1 & 5 & 60.7 & 23 & 10.5 & 4 & 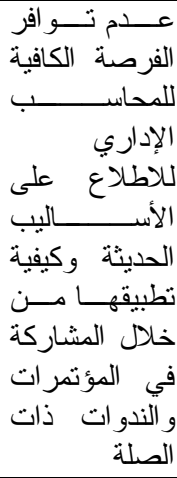 \\
\hline 0.855 & 3.710 & 0 & 0 & 13.1 & 5 & 15.9 & 6 & 57.9 & 22 & 13.1 & 5 & 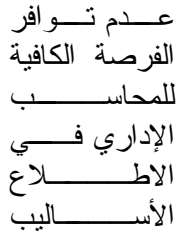 \\
\hline
\end{tabular}




\begin{tabular}{|c|c|c|c|c|c|c|c|c|c|c|c|c|}
\hline \multirow{2}{*}{ المعياري } & \multirow{2}{*}{ الحسابي } & \multicolumn{2}{|c|}{ غير مو افقى } & \multicolumn{2}{|c|}{ غير موافق } & \multicolumn{2}{|c|}{ محايد } & \multicolumn{2}{|c|}{ موافق } & \multicolumn{2}{|c|}{ موافق بشدة } & (1) \\
\hline & & $\%$ & عدد & $\%$ & عدد & $\%$ & عدد & $\%$ & عدد & $\%$ & عدد & السؤال \\
\hline & & & & & & & & & & & & 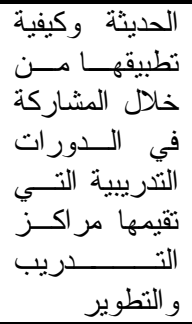 \\
\hline 0.907 & 3.578 & 2.6 & 1 & 7.9 & 3 & 31.6 & 12 & 44.9 & 17 & 13.1 & 5 & 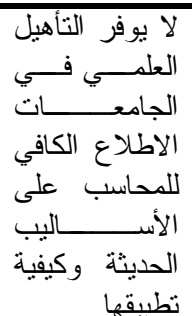 \\
\hline 0.723 & 3.947 & 0 & 0 & 5.2 & 2 & 13.1 & 5 & 63.2 & 24 & 18.5 & 7 & 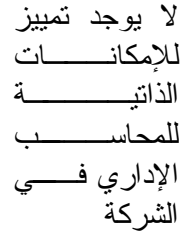 \\
\hline 0.805 & 3.731 & & & & & & & & & & & المتوسط العام \\
\hline
\end{tabular}

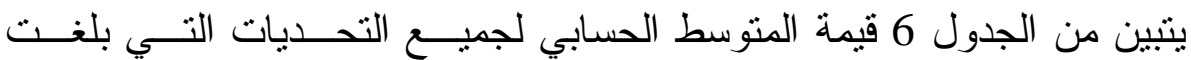

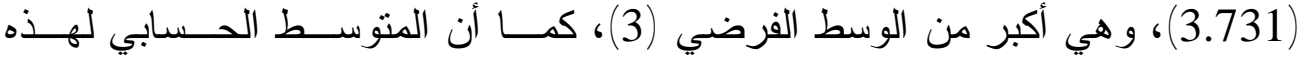

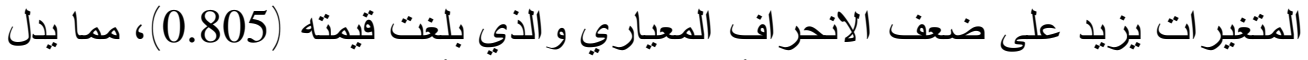

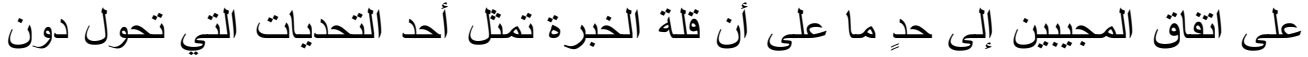

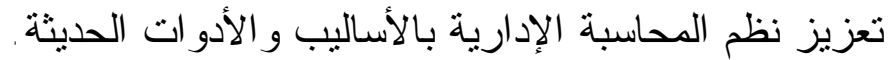

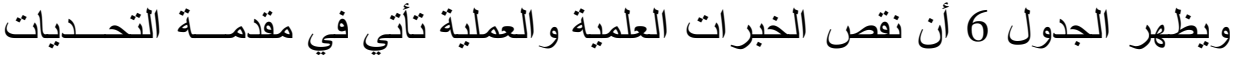

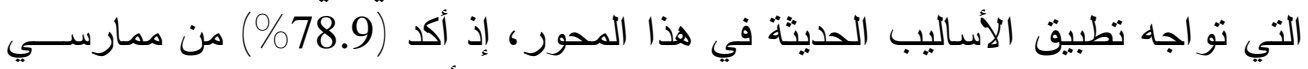

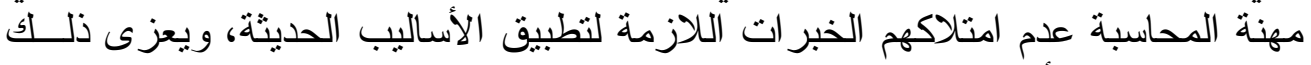

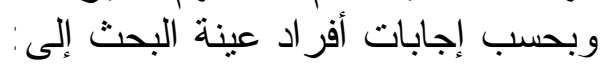

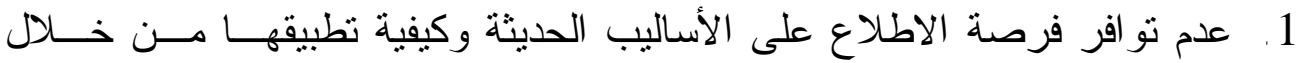
المشاركة في المؤتمر ات والندو ات ذات الصلة، إذ أكد (71.2\%) من أفر اد العينة 


\section{الزيدي [328]}

على أهمية هذا التحدي، وبلغت درجة المو افقة عليه (3.631) وبانحر اف معياري

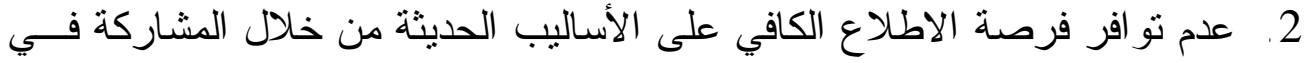

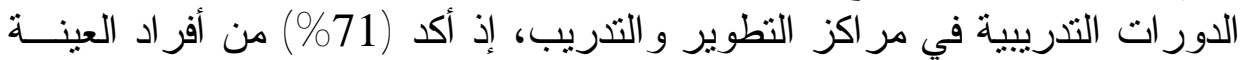

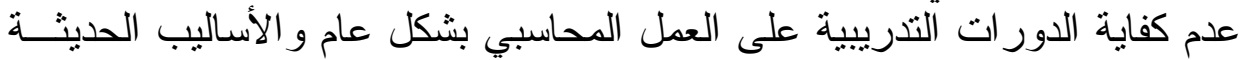

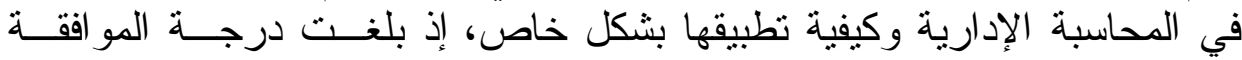

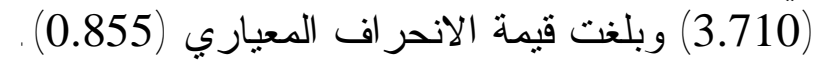

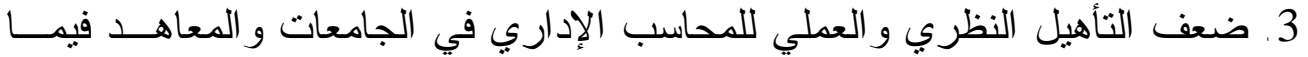

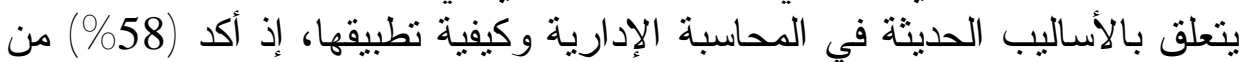

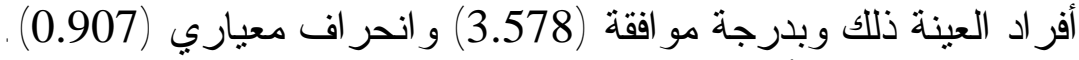

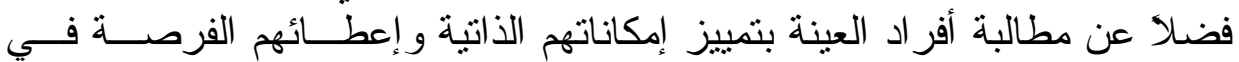

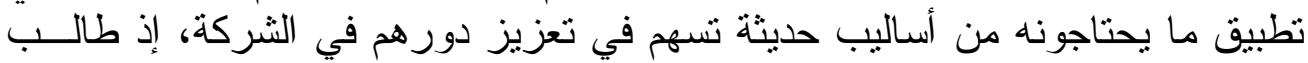

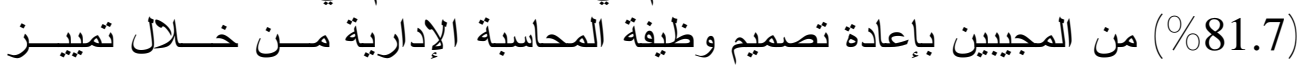
الإمكانات الذاتية للمحاسبين، ولعل أحد أسباب ذلاعن أن أن هناك الكثير من الذين الذين يمارسون

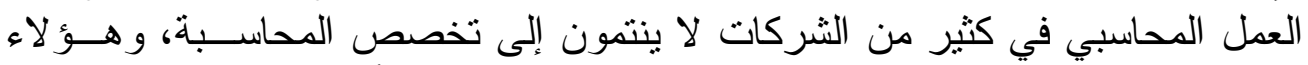

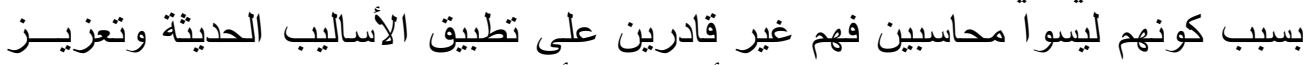
نظم المحاسبة الإدارية في شركاتهم بالأدو ات و الأساليب الحديثة فئنة

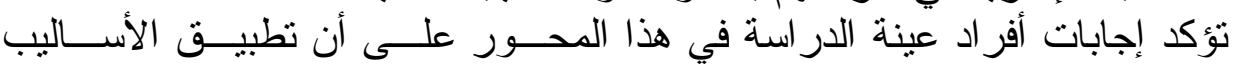

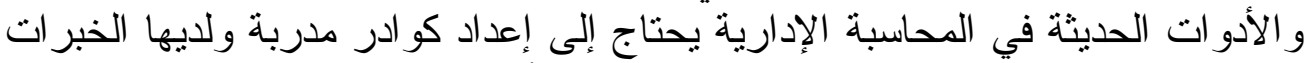

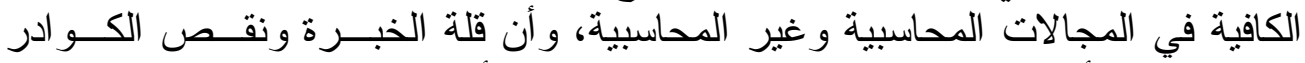

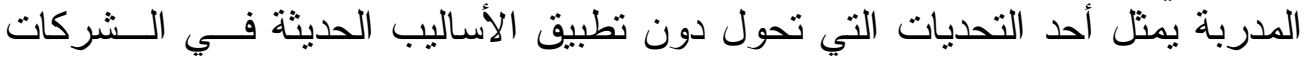
العر اقية وهذا ما يثبت فرضية الَّبث البحت الثانية.

ت. التحديات المتعلقة بقياس المنفعة للأدوات الحديثة

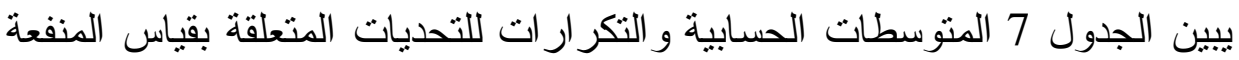

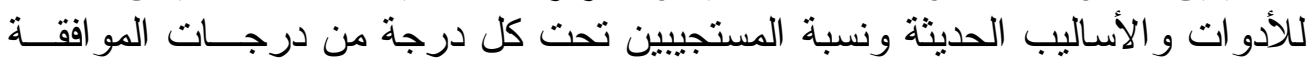

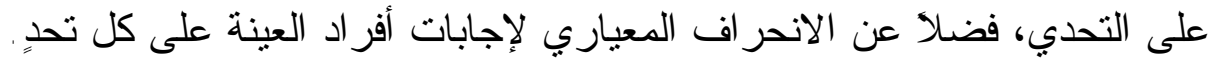

\section{الجدول 7}

المقاييس الإحصائية لإجابات أفراد العينة حول

التحديات المتعلقة بقياس الإندائة لإبات المنفة للأدوات العديثة حولة 


\begin{tabular}{|c|c|c|c|c|c|c|c|c|c|c|c|c|}
\hline \multirow{2}{*}{$\frac{\bar{y}}{\bar{y}} \stackrel{\overline{3}}{9}$} & \multirow[t]{2}{*}{ الحسابي } & \multicolumn{2}{|c|}{ مو غير بشد } & \multicolumn{2}{|c|}{ غير موافق } & \multicolumn{2}{|c|}{ محايل } & \multicolumn{2}{|c|}{ موافق } & \multicolumn{2}{|c|}{ موافق بشدة } & \multirow[b]{2}{*}{ السؤ ال } \\
\hline & & $\%$ & عدد & $\%$ & عدد & $\%$ & عدد & $\%$ & عدد & $\%$ & عدد & \\
\hline 0.739 & 4.078 & 0 & 0 & 2.6 & 1 & 15.8 & 6 & 52.6 & 20 & 29 & 11 & 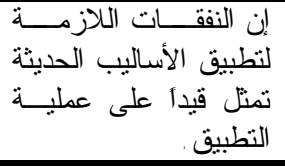 \\
\hline 0.664 & 3.921 & 0 & 0 & 2.6 & 1 & 18.4 & 7 & 63.2 & 24 & 15.8 & 6 & أنشاط الطبيق ما يتلاءه من الألتصادية \\
\hline 0.753 & 4.105 & 0 & 0 & 5.2 & 2 & 7.9 & 3 & 57.9 & 22 & 29 & 11 & تصميم وظيفة الإلكاسبة الإعـادة \\
\hline 0.655 & 4.21 & 0 & 0 & 2.6 & 1 & 5.2 & 2 & 60.7 & 23 & 31.5 & 12 & 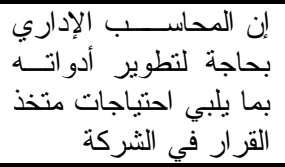 \\
\hline 0.703 & 4.078 & & & & & & & & & & & المنوسط العام \\
\hline
\end{tabular}

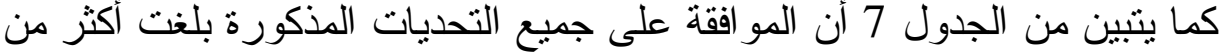

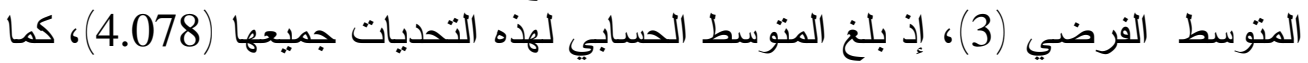
بلغت قيمة الانحر اف المعياري (303)، (30.703، مما بدل على قلة تباين الآراء حول المو افقة على هذه التحديات . ويبين الجدول 7 أيضاً، أن القيمة التي سوف تضيفها الأساليب الحديثة قد تبــرر

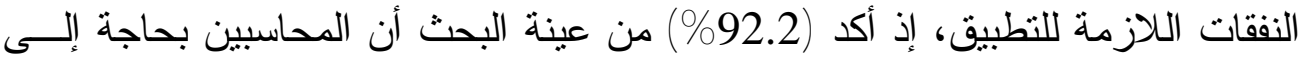

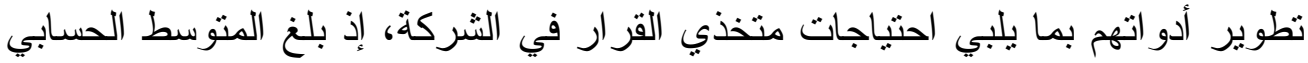

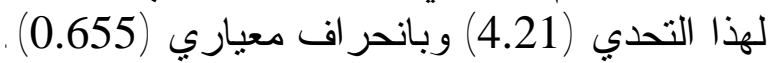

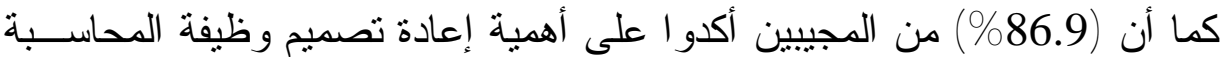

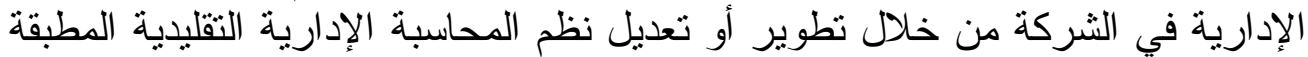

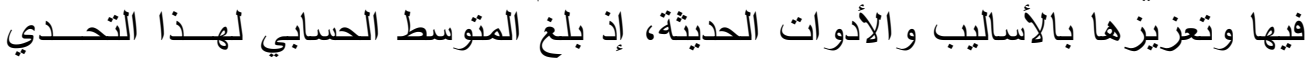
جميعها (4.105) وبانحر اف معياري (0.753) . 
[330] الزيدي

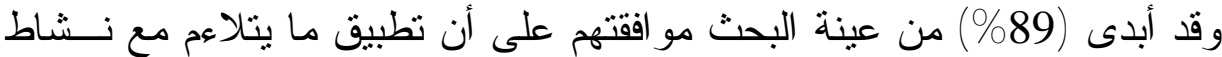

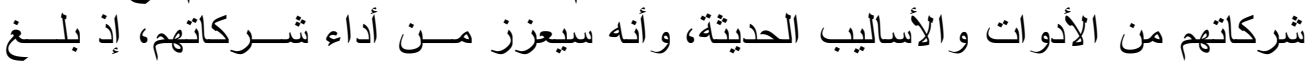

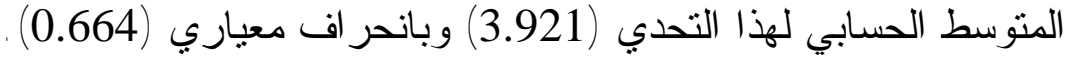

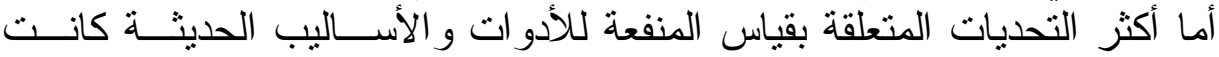

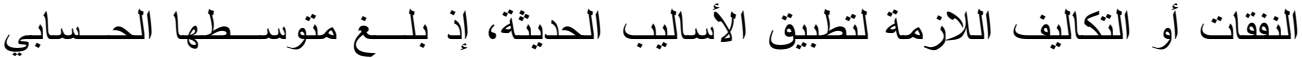

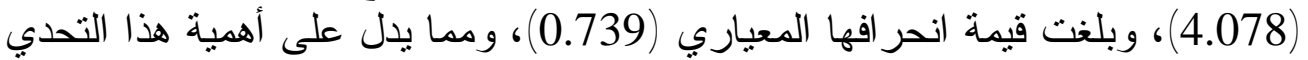

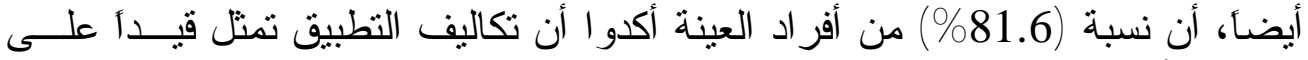
تطبيق الأساليب الحديثة.

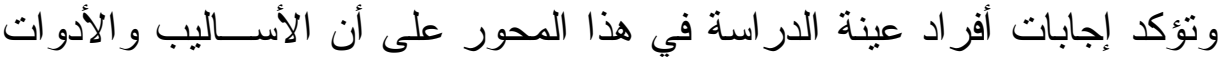

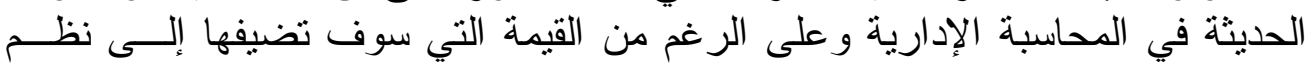

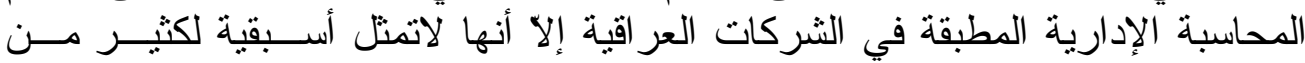

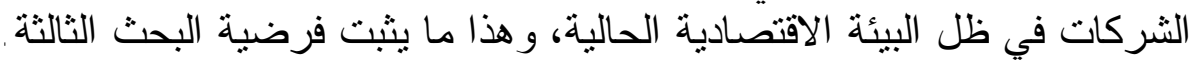

ث. التحديات المتعلقة بملاعمة بحوث المحاسبة الإدارية

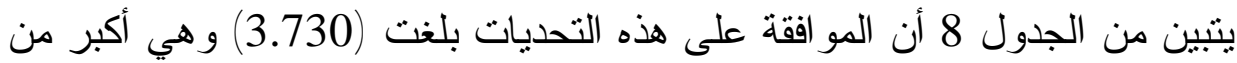

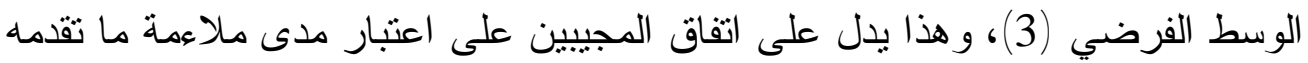

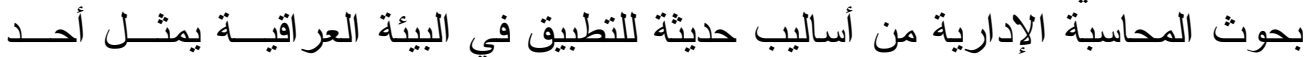

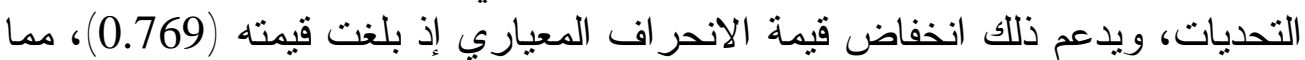
يدل على اتفاق المجييين إلى حلٍٍ ما على هذا التحدي. التحدي.

\section{الجدول 8}

المقاييس الإحصائية لإجابات أفر اد العينة حول

التحديات المتعلقة بملاعمة بحوث الإبات المحاسبة الإدارية حرلة

\begin{tabular}{|c|c|c|c|c|c|c|c|c|c|c|c|c|}
\hline \multirow[t]{2}{*}{ الالمعياري } & \multirow[t]{2}{*}{ الحسابي } & \multicolumn{2}{|c|}{ موافقي } & \multicolumn{2}{|c|}{ غير موافق } & \multicolumn{2}{|c|}{ محايد } & \multicolumn{2}{|c|}{ موافق } & \multicolumn{2}{|c|}{ موافق بثدة } & \multirow{2}{*}{ السؤل /لقيس الإجابة } \\
\hline & & $\%$ & عدد & $\%$ & عدد & $\%$ & عدل. & $\%$ & عدد & $\%$ & عال & \\
\hline 0.815 & 3.578 & 0 & 0 & 13.1 & 5 & 23.7 & 9 & 55.2 & 21 & 7.9 & 3 & 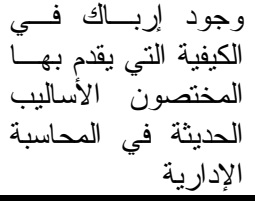 \\
\hline 0.815 & 3.578 & 0 & 0 & 13.1 & 5 & 23.7 & 9 & 55.2 & 21 & 7.9 & 3 & 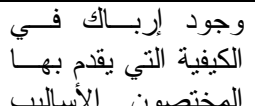 \\
\hline
\end{tabular}




\begin{tabular}{|c|c|c|c|c|c|c|c|c|c|c|c|c|}
\hline \multirow[t]{2}{*}{ الالحيراف } & \multirow[t]{2}{*}{ الوسابط } & \multicolumn{2}{|c|}{ بشئ بوافي } & \multicolumn{2}{|c|}{ غير موافق } & \multicolumn{2}{|c|}{ محايد } & \multicolumn{2}{|c|}{ موافق } & \multicolumn{2}{|c|}{ موافق بشدة } & \multirow[b]{2}{*}{ السؤال } \\
\hline & & $\%$ & عدد & $\%$ & علد & $\%$ & عدد & $\%$ & عدد & $\%$ & عدد & \\
\hline & & & & & & & & & & & & الإدارية في المحاسبة \\
\hline 0.880 & 3.473 & 0 & 0 & 18.4 & 7 & 23.7 & 9 & 50 & 19 & 7.9 & 3 & 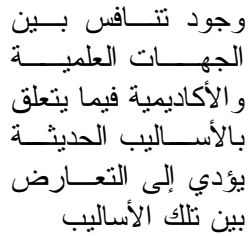 \\
\hline 0.870 & 3.921 & 0 & 0 & 10.5 & 4 & 10.5 & 4 & 55.3 & 21 & 23.7 & 9 & 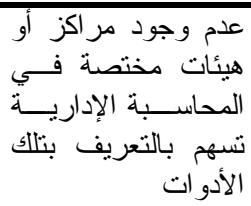 \\
\hline 0.510 & 3.947 & 0 & 0 & 2.6 & 1 & 7.9 & 3 & 81.6 & 31 & 7.9 & 3 & 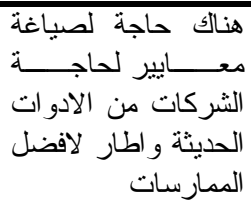 \\
\hline 0.769 & 3.730 & & & & & & & & & & & المتوسط العام \\
\hline
\end{tabular}

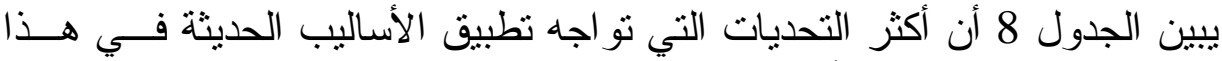

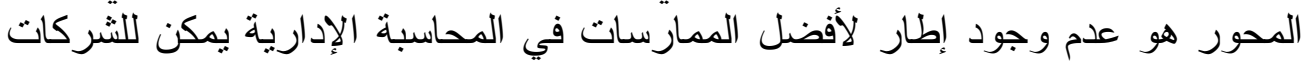
الاسترشاد به في تطوير نظم المحاسبة الإدارية المطبقة فيها، إذ أكد (88.5\%) مسنـن

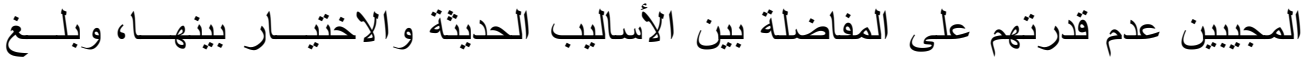

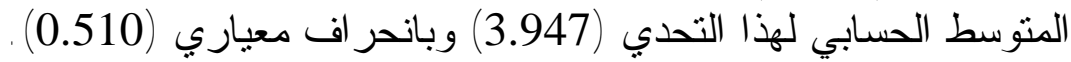

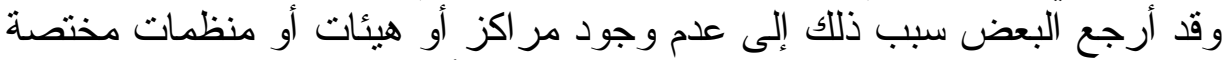
في المحاسبة الإدارية في العراق تسهم في التعريف بالأساليب الحديثة وكيفية تطبيقها

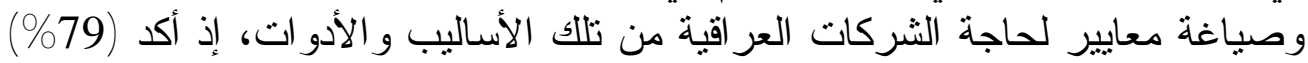

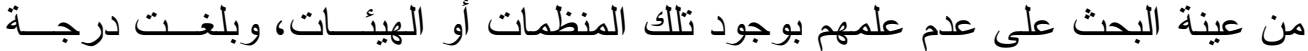

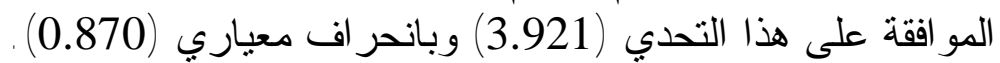
في حين أرجع البعض الآخر أسباب عدم التطبيق إلى الإربالك في طريقة تقـئديم

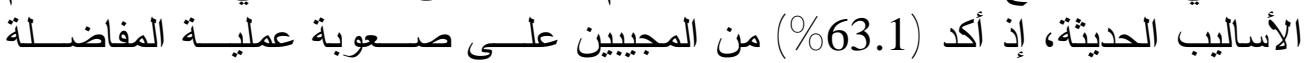

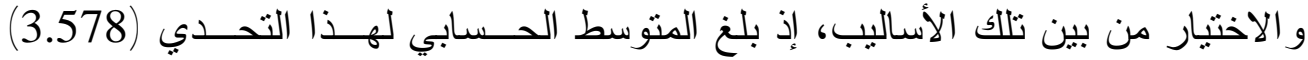
وبإنحر اف معياري (0.815) . 


\section{[332] [ الزيدي}

وقد أبدى (57.9\%) من المجيبين مو افقته على أن المنافسة بين الجهات العلمية

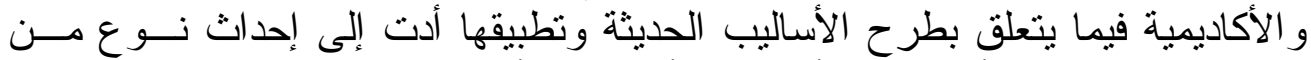

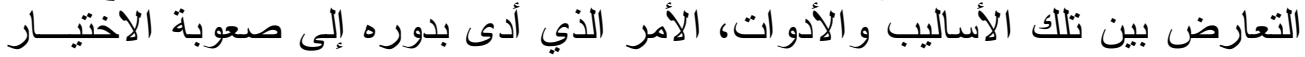
و المفاضلة بينها، وبلغت درجة المو افقة على هذا التحدي (3.473) وبانحر الإن الف معياري

تؤكد إجابات أفر اد عينة الدر اسة في هذا المحور أن عدم وجود مر اكز أو هيئات

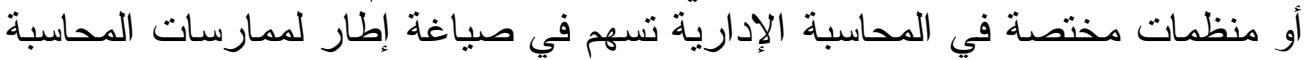

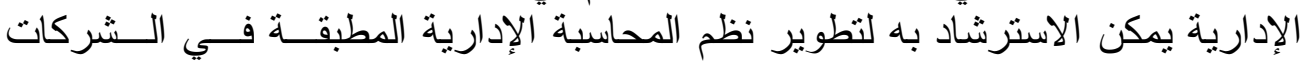

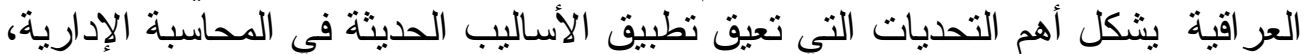

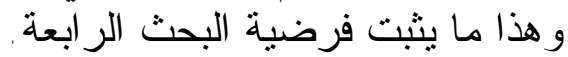

1. إن الأساليب الحديثة هي السمة المميزة لنطور المحاسبة الإدارية وهي نتاج لتنازم منطقي بين التهديدات و الفرص التي تو اجه المنظمات في بيئة الأعمال الحديثة.

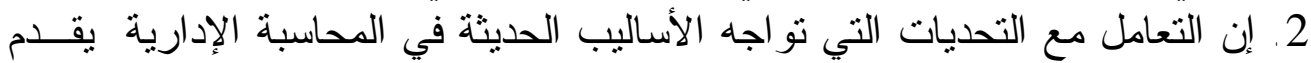

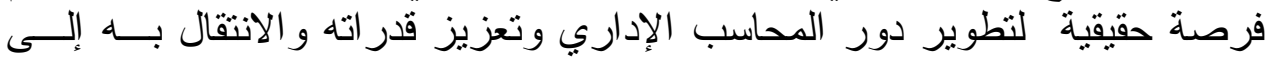

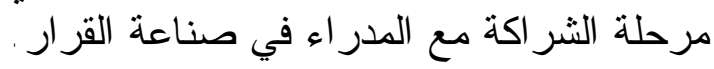
3. إن عدم نو افر الصدلاحيات للتوسع في إجر اءع التحاء التحديثات على نظم المحاسبة الإدارية و التقيد بالتعليمات أدى بالكثير من الثركات العر اقية إلى التأخر في تطبيق الأساليب الحديثة. 4. إن عدم وجود أقسام للمحاسبة الإدارية في الثركات العر اقية أدى إلى قيام الأقـسام

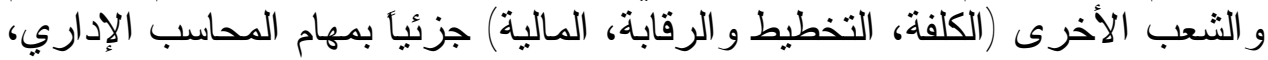
وقد أضاف ذلك تحدياً جديداً أمام تطبيق الأساليب الحديثة في النية المحاسبة الإدارية.

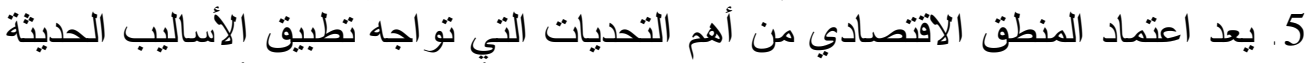

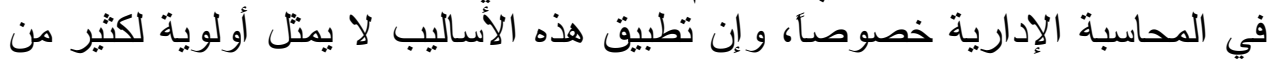

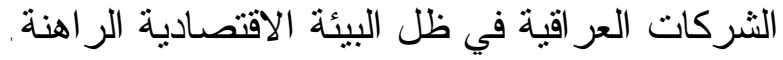

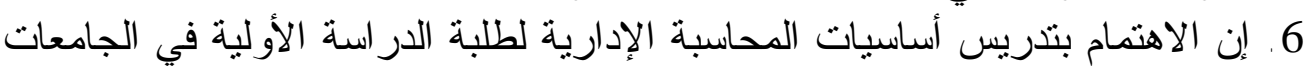

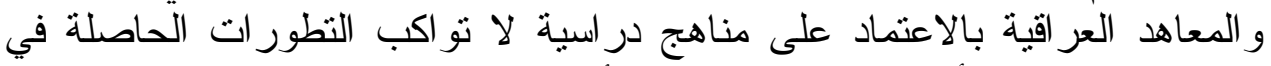

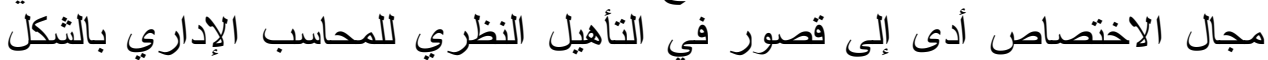
الذي أثز في قدرته على نطبيق الأساليب الحديثة. 
7.عدم مو اكبة ممارسي المهنة للمستجدات في المحاسبة الإدارية من خلال المشاركة

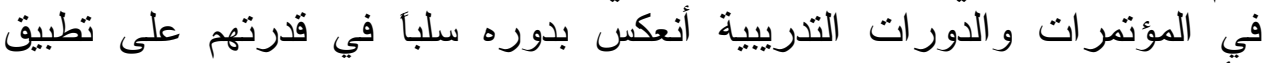
الآساليب الحديثة.

8. عدم وجود مر اكز أو هيئات أو منظمات عر اقية مختصة في المحاسبة الإدارية على الإئ

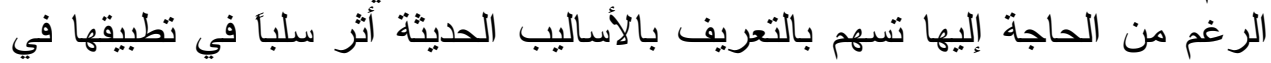

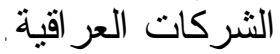

ثانياً - التوصيات

1. يؤكد البحث على نوعية المحاسبين الإداريين المطلوبين لبيئة الأعمال الحديثة فهر

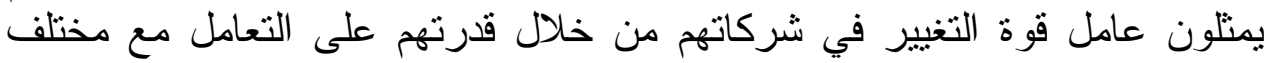

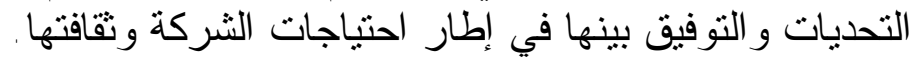

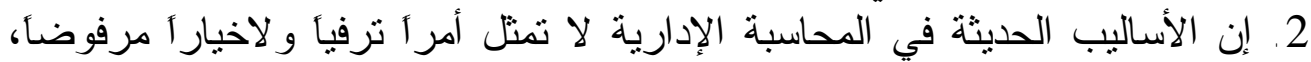

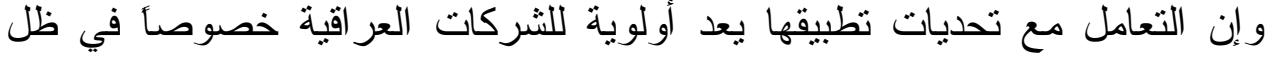

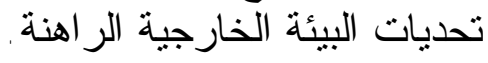
3. على الثركات العر اقية إعطاء اهتمام أكبر لوظيفة الرية المحاسبة الإدارية و إنثاء أقسام

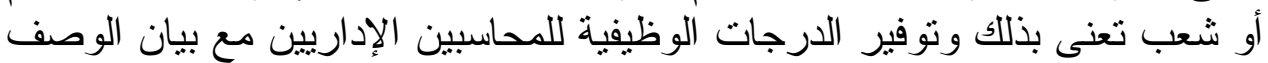

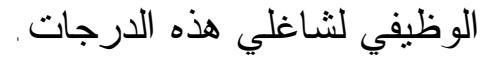
4. ضرورة قيام الجهات العلمية والأكاديمية بإعادة تقييم ممارسات المحاسبة الإدارية المطبقة في الثركات العر اقية وصياغة إطار مفاهيمي لأفضل ممارسات المحاسبة الإدارية.

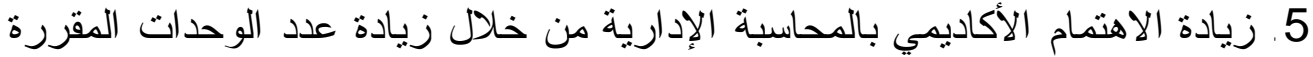

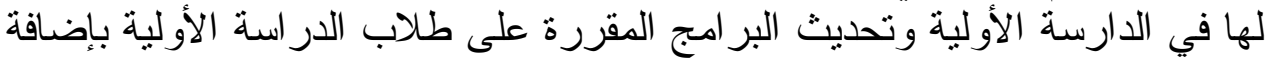

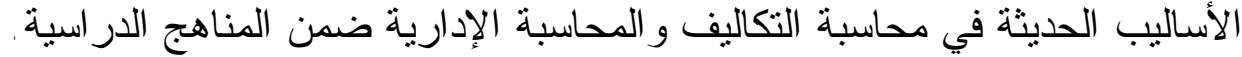

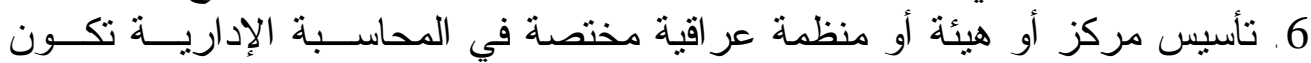

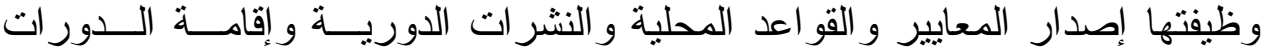

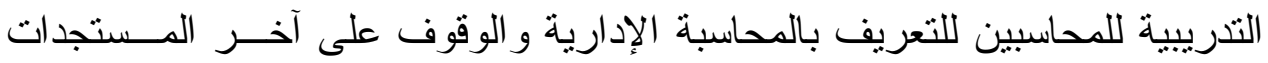

1. Atkinson. A, 1989, "A management accounting constitution", CMA Magazine, vol 63, No 5, JUNE.

2. Burns .J, 2000, " The changing nature of management accounting and the emergence of hybrid accountant", www.ifac.org/articals .

3. Cokins .G, 2001, " A management accounting framework", international Magazine of strategic cost management, vol 1 , No 2 . 


\section{الزيدي [334]}

4. Dminik .T, \& Kudar .R , 1989," Do not throw out the baby with the path water" , CMA Magazine, vol 63, No 6, JULY-AUGUST.

5. Garg .A, Ghosh .D, Hudik .J , Nowaki .C, 2003, "Roles and practices in management accounting today", strategic finance, JULY.

6. International Federation Of Accountants (IFAC), 1998, "Management accounting concepts (IMP 1)", Financial Management \& Management Accounting Committee(FMAC)), MARCH.

7. Kaplan .R.S, 1984," The evolution of management accounting", The Accounting Review, JULY. www.maaw.info.index/managementaccounting.

8. Luther .R , \& Abdel-kader . M, 2006, "Management accounting practices in the UK food industry", CIMA the chartered institute of management accounting, London .

9. Mai .A, Ahmed .F, 2005, "Strategic management accounting practices in the $21^{\text {st }}$ century", The Cost and Management Journal, vol 33, No 4.

10. Ning .Y, 2005, " The development of costing system: a historical perspective", Journal of modern accounting and auditing, vol 1, No 2.

11. Sharma .R, 2000, " From relevance lost to relevance regained : management accounting practices in the new millennium". www.ifac.org/artical

12. Shields .D, Chow .C , Kato .Y, Nakagaw .Y, 1991," Management accounting practices in the U.S and Japan" , Journal of international financial management and accounting, vol 3 , No 1.

13. Steeves .B, 1990, " Trends in management accounting", CMA Magazine, vol 64, No 3,MARCH.

14. www.esnips.com/search/costaccounting, "Basic Cost Concepts". 